\title{
Burial-exhumation cycles in the continental crust derived from Mediterranean field studies and numerical modelling
}

Cyclische perioden van begraving en exhumatie in de continentale korst, bepaald uit Mediterrane veldstudies en numerieke modellen

(met een samenvatting in het Nederlands)

\section{Proefschrift}

ter verkrijging van de graad van doctor aan de Universiteit Utrecht op gezag van de rector magnificus, prof.dr. H.R.B.M. Kummeling, ingevolge het besluit van het college voor promoties in het openbaar te verdedigen op vrijdag 28 mei 2021 des ochtends te 10.15 uur

door

Kristóf Porkoláb

geboren op 31 juli 1992 te Miskolc, Hongarije 
Promotoren:

Prof. dr. L.C. Matenco

Prof. dr. D. Sokoutis

Copromotoren:

Dr. E. Willingshofer

Dr. W.W.W. Beekman

This study was financially supported by the Europen Union's MSCA-ITN-ETNproject SUBITOP 674899. 
"In every walk with Nature one receives far more than he seeks"

John Muir 


\section{Members of the Reading Committee:}

Prof. Dr. C. Gaina

Prof. Dr. F. Gueydan

Prof. Dr. F. Neubauer

Prof. Dr. M. Drury

Dr. E. Moulas
University of Oslo, Norway

Université de Montpellier, France

Univeristät Salzburg, Austria

Utrecht University, Netherlands

Johannes Gutenberg-Universität Mainz, Germany

This is Utrecht studies in Earth Sciences volume 231

ISBN 978-90-6266-596-9

C Kristóf Porkoláb 2021

Printed in the Netherlands by Ipskamp Printing

Cover: Boulder of metamorphic rock washed by the Aegean Sea (Skopelos island)

All rights reserved. No part of this publication may be reproduced or transmitted in any form or by any means, electronic or mechanical, including photocopying, recording, or by any information storage and retrieval system without prior written permission from the author. 


\section{Contents}

Chapter 1. Introduction

$1.1 \quad$ The burial and exhumation of continental crust ....................................... 9

1.2 Tectonic setting of the Hellenides and the Betics in the Mediterranean

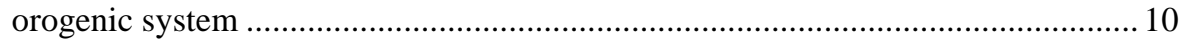

1.2.1 Tectonic setting of the Hellenides ....................................................... 11

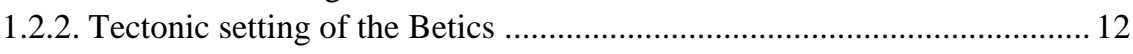

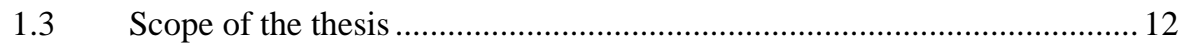

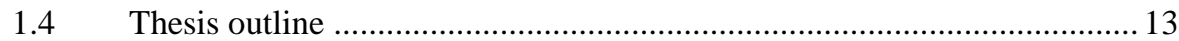

Chapter 2. Cretaceous-Paleogene tectonics of the Pelagonian Zone:

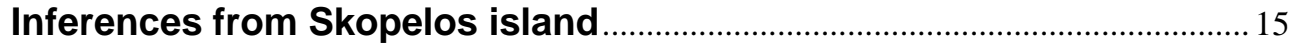

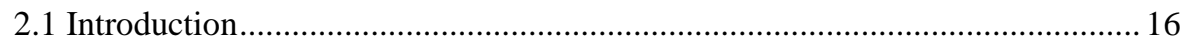

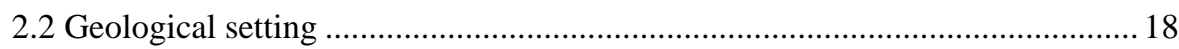

2.2.1 Mesozoic - Paleogene geological evolution of the Pelagonian zone......... 18

2.2.2 Geology of Skopelos ............................................................................ 19

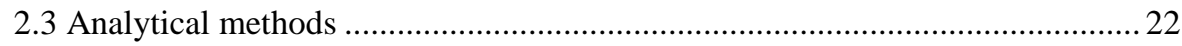

2.3.1 Microprobe analyses for pressure-temperature calculations ....................... 22

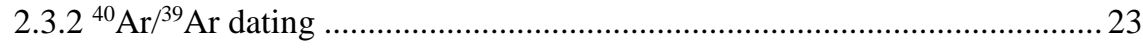

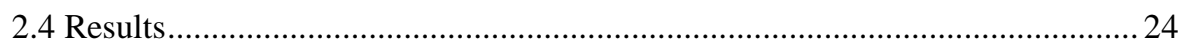

2.4.1 Structural mapping and kinematics of ductile deformation ......................... 24

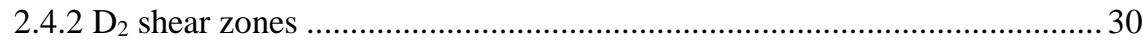

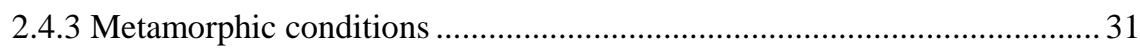

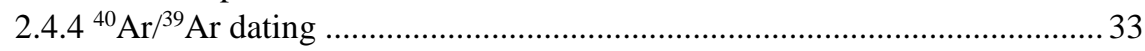

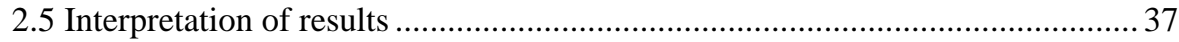

2.5.1 Late Jurassic-Early Cretaceous evolution of Skopelos ............................... 37

2.5.2 Late Cretaceous-Paleogene evolution of Skopelos ....................................... 38

2.6 Implications for the Early Cretaceous tectonics of the Pelagonian margin....... 40

2.6.1 Correlation of Early Cretaceous tectonic events in the Pelagonian zone... 40

2.6.2 Early Cretaceous underthrusting of the Pelagonian margin........................ 42

2.7 Implications for the Late Cretaceous - Paleogene tectonics of the Pelagonian zone.

2.7.1 Correlation of Late Cretaceous - Paleogene tectonic burial in the Aegean

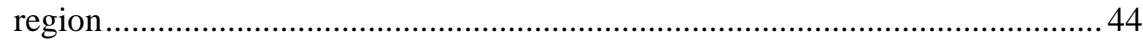

2.7.2 Paleogene accretionary wedge evolution on Skopelos .............................. 45

2.7.3 Top-NE exhumation of the accretionary wedge ......................................... 46 
Chapter 3. Strain localization during burial and exhumation of the continental upper crust: A case study from the Northern Sporades (Pelagonian thrust sheet, Greece) …………............................................... 50

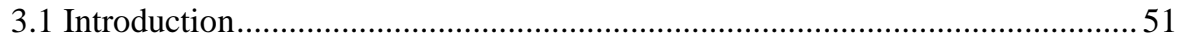

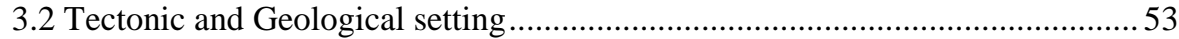

3.3 Strain localization and the kinematics of deformation ...................................55

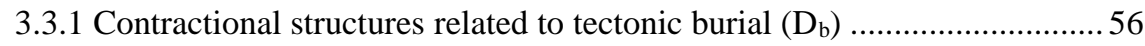

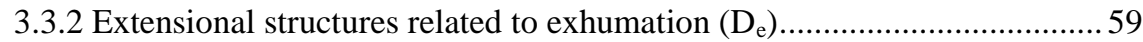

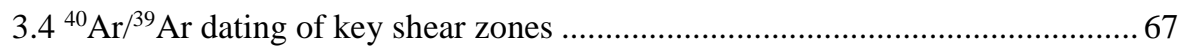

3.4.1 Activity of the Kastro shear zone (Location 1 ): ${ }^{40} \mathrm{Ar} /{ }^{39} \mathrm{Ar}$ age spectra ......6 68

3.4.2 Activity of the Skiathos town shear zone: ${ }^{40} \mathrm{Ar} /{ }^{39} \mathrm{Ar}$ age spectra ...............6 69

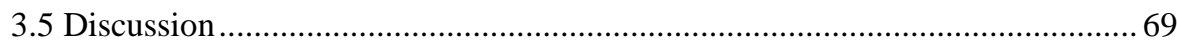

3.5.1 Implications for the nappe structure of the Northern Sporades ................69

3.5.2 Geometry of upper crustal shortening: the role of stratigraphy ................. 71

3.5.3 Strain localization during extensional exhumation ................................ 74

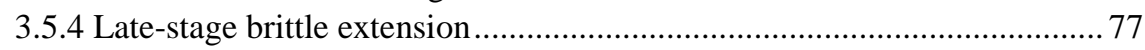

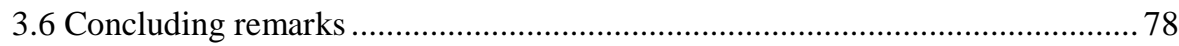

Chapter 4. Two Cenozoic burial phases revealed by structural and geochronological data from the Nevado-Filábride complex (Sierra de

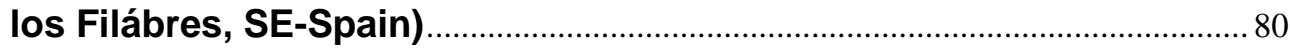

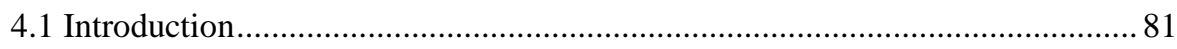

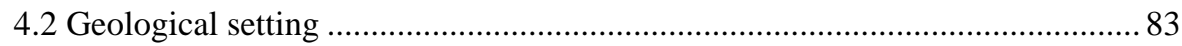

4.2.1 Metamorphic conditions and kinematic characteristics of the NFC ..........86

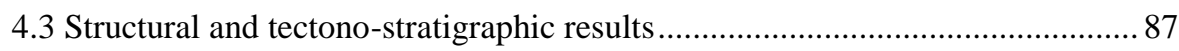

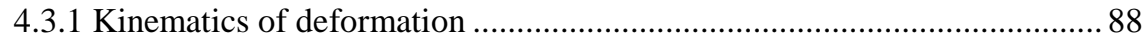

4.3.2 Shear zones and tectonic units in the eastern Sierra de los Filábres .......... 91

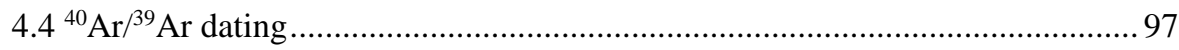

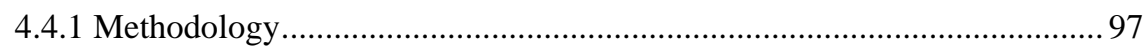

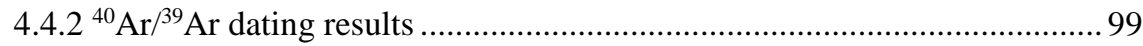

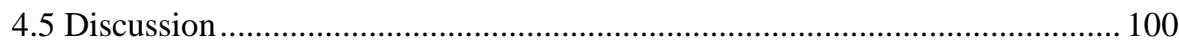

4.5.1 Interpretation of ${ }^{40} \mathrm{Ar} /{ }^{39} \mathrm{Ar}$ ages and timing of tectono-metamorphic events......................................................................... 10

0

4.5.2. Superposition of Miocene thrusting and extension: the mechanics of exhumation and the structural definition of the NFC and the AC .................... 102

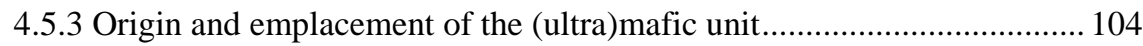

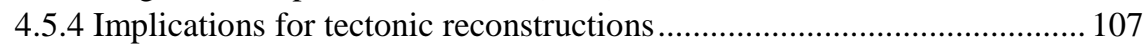


4.6 Conclusions

Chapter 5. Extrusion of subducted crust explains the emplacement of far-travelled ophiolites

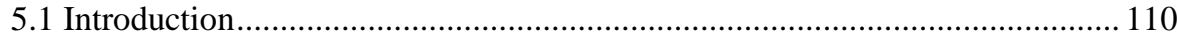

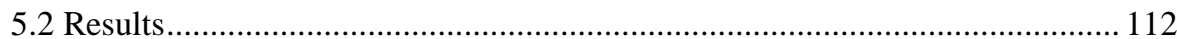

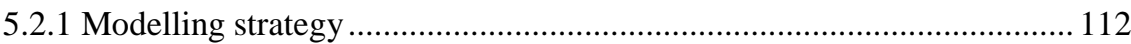

5.2.2 General evolution of the reference model............................................. 114

5.2.3 Ductile nappe formation: the onset of exhumation ............................... 116

5.2.4 Interplay between crustal extrusion and upper plate necking .................. 116

5.2.5 Key parameters controlling crustal extrusion and far-travelled ophiolite

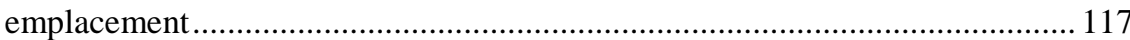

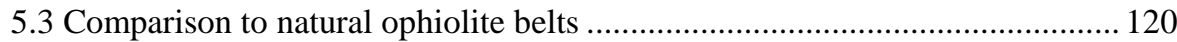

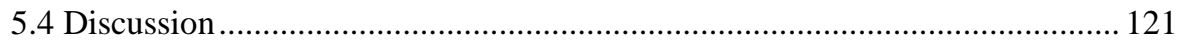

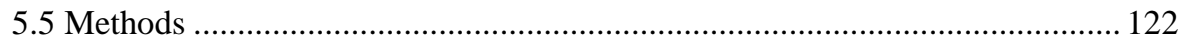

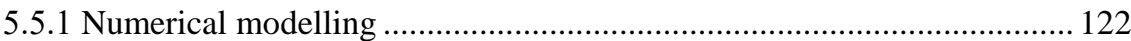

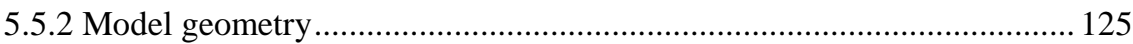

5.6 Supplementary Note 1: Explanation for the datasets collected from natural

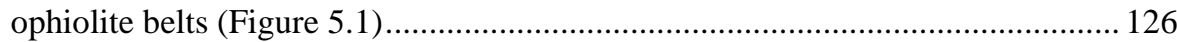

5.7 Supplementary Note 2: Convergence velocity test ..................................... 127

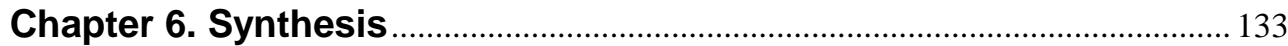

6.1 The tectono-metamorphic interpretation of Ar/Ar ages ................................. 134

6.2 Kinematic characteristics of continental burial-exhumation cycles ............... 135

6.3 Exhumation mechanisms of buried continental crust..................................... 136

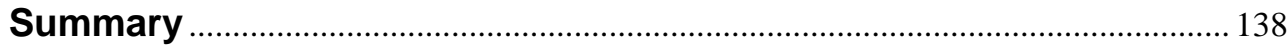

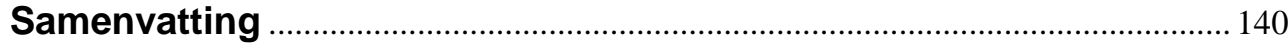

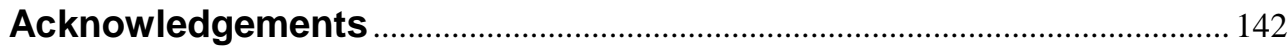

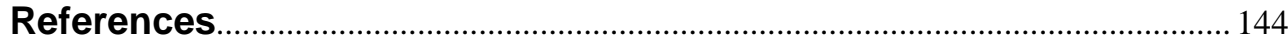

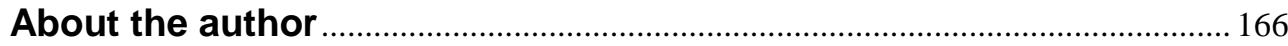


Chapter 1. Introduction 


\subsection{The burial and exhumation of continental crust}

The burial and subsequent exhumation of continental crust are key processes at convergent plate boudaries, shaping the architecture of mountain belts and influencing the general evolution of subduction zones, which provide one of the main driving forces of our dynamic planet. Subduction of continental rocks may occur in settings where the upper plate is continental (continent-continent convergence) or where the upper plate is oceanic (obduction, Dewey, 1976; Dewey and Bird, 1970). In either case, continental rocks may reach various burial depths in the lower plate of subduction zones, depending on the mechanical conditions of their accretion to the upper plate. Shallow accretion of continental crust to the upper plate results in its incorporation in accretionary wedges (Figure 1.1). The amount of accreted rocks substantially influences the overall architecture of resulting mountain ranges as well as the exhumation of the accreted continental rocks back to the surface (e.g. Dahlen, 1990; Platt, 1986). The part of continental crust that is not involved in shallow accretion, undergoes deep burial, i.e. continental subduction (Figure 1.1). Continental rocks are naturally buoyant, and hence typically resist long-term subduction into the Earth's mantle, leading to the (partial) exhumation of the subducted material. The balance between subduction/exhumation and the related structural evolution of continental subduction influence the architecture of mountain belts (e.g. Vogt et al., 2017), the overall evolution of subduction zones (e.g. van Hinsbergen et al., 2020), and the recycling of continental material (e.g. Clift and Vannucchi, 2004; Plank, 2005). Existing models that aim to describe and explain continental subduction-exhumation cycles mainly differ in the controlling tectonic process or mechanism responsible for the exhumation of the subducted continental rocks, besides the effects of surface processes (Ring et al., 1999). The proposed models include back-arc extension induced by the roll-back of the subducted slab (e.g. Brun and Faccenna, 2008; Brun et al., 2016), delamination of a thickened continental lithosphere (e.g. Platt and Vissers, 1989; Seber et al., 1996), the buoyancy-driven extrusion of the subducted continental crust (e.g. Chemenda et al., 1996; Herwegh et al., 2017), exhumation in a subduction-channel (Cloos and Shreve, 1988), or slab extraction (Froitzheim et al., 2003).

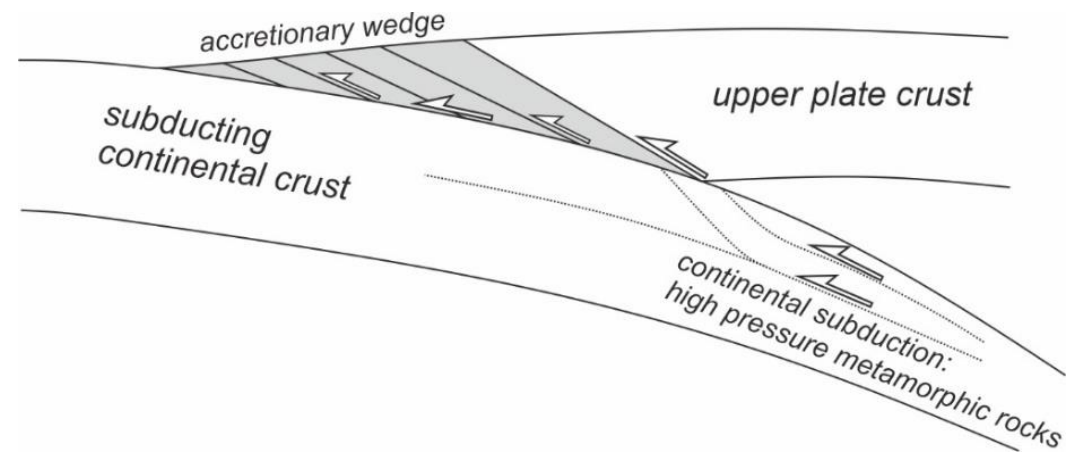

Figure 1.1 Schematic sketch showing the shallow (accretionary wedge) and deep (continental subduction) burial of continental rocks in a subduction zone. 
In cases where subduction initiates within the oceanic lithosphere, the oceanic lower plate subducts into the mantle (Pearce et al., 1984) and drags the attached continental margin into the subduction zone. This situation leads to regional thrusting of oceanic lithosphere over continental crust, i.e. ophiolite obduction (Dewey, 1976; Gealey, 1977). Ophiolite obduction is a relatively poorly understood process in plate tectonics, largely due to the apparent difficulty of emplacing denser oceanic lithosphere over lighter continents, as well as due to the difficulty of quantifying subduction of continental plates. Obduction often results in the short-term, deep burial (subduction) of the continental crust, which is followed by exhumation (e.g. Agard et al., 2010; Brovarone and Agard, 2013; Chemenda et al., 1996; Kilias et al., 2010). Obduction is generally followed by the final closure of the oceanic basin, resulting in continental collision that partially obliterates the geological record of a previous obduction process. In such cases, for example in the Hellenides (e.g. Schmid et al., 2008), it is especially challenging to unravel the conditions of the superposed continental burialexhumation cycles.

The current understanding of continental burial-exhumation processes is based on decades of research in structural geology (Tate et al., 2015; Wheeler, 1991), metamorphic petrology (e.g. Rubatto et al., 2011; Zheng, 2012), geochronology (e.g. Glodny et al., 2008), deep-Earth geophysics (e.g. Hetényi et al., 2018; Wortel and Spakman, 2000), and geodynamic modelling (e.g. Vogt et al., 2017; Willingshofer et al., 2013). In particular, the integration of various methods and datasets has proven to be key in unravelling the spatial and temporal conditions of continental burial-exhumation cycles (Behr and Platt, 2012; van Hinsbergen et al., 2020).

\subsection{Tectonic setting of the Hellenides and the Betics in the Mediterranean orogenic system}

The Mediterranean orogenic belt underwent a complex geodynamic evolution as part of the Africa-Eurasia convergent plate boundary zone (Figure 1.2). The present-day geometry of mountain belts and sedimentary basins are the products of long-lasting crustal deformation that has been driven by the subduction of oceanic and continental lithosphere and associated mantle flow (e.g. Faccenna et al., 2014; Royden, 1993; van Hinsbergen et al., 2020). The subduction of continental lithosphere resulted in the-shallow or deep-accretion of the continental upper crustal domains to the upper plate of the subduction systems, resulting in the formation of regional nappe stacks, for instance in the Dinarides, Hellenides, Betics, or Appenines (e.g. Handy et al., 2010; Jolivet and Brun, 2010; Schmid et al., 2008; van Hinsbergen et al., 2020; van Hinsbergen et al., 2005). The Mediterranean system hence provides an ideal region to study the conditions of continental burial-exhumation cycles, either by the acquisition of new field data for constraining tectonic models, or by developing new models and using the wealth of existing data for model validation and testing. 


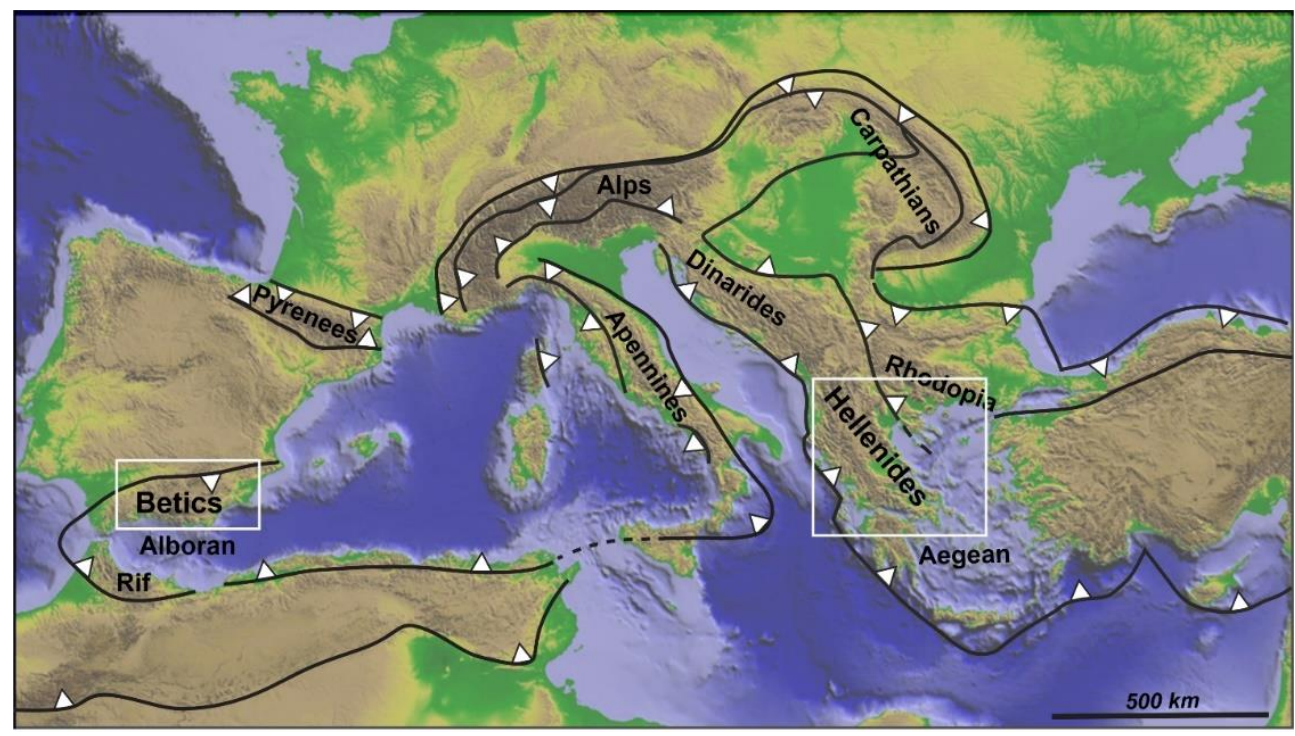

Figure 1.2 Simplified map of the Alpine-Mediterranean orogenic system highlighting the main structures. White rectangles show the two studied orogenic segments (Hellenides and Betics), the topography is based on SRTM data (Farr et al., 2007).

\subsubsection{Tectonic setting of the Hellenides}

The Hellenides are a NW-SE trending mountain range in the eastern Mediterranean (Figure 1.2), made up predominantly by stacked nappes of continental upper crust and subordinately by obducted ophiolite sheets. The complex geodynamic evolution of the Hellenides included the Triassic opening of the Neotethys ocean (e.g. Bortolotti and Principi, 2005; van Hinsbergen et al., 2020), the initial closure of the ocean by ophiolite obduction in Middle-Jurassic to Early Cretaceous times (e.g. Bortolotti et al., 2013; Schmid et al., 2019), the final closure of the ocean by Cretaceous-Paleogene continental subduction/collision (e.g. Jolivet and Brun, 2010; Ricou et al., 1998; van Hinsbergen et al., 2005), and syn-to postorogenic extension since the Eocene, driven by the roll-back of the subducted slab (Brun et al., 2016; Brun and Sokoutis, 2007; Jolivet and Brun, 2010; Le Pichon et al., 1981). Due to the superposition of obduction and subsequent continental nappe stacking, certain geological units (namely the Pelagonian zone) experienced multiple phases of tectonic burial and exhumation within the same orogenic cycle (Kilias et al., 2010; Most, 2003). Middle Jurassic intra-oceanic subduction and the obduction of ophiolite sheets in the Late Jurassic-earliest Cretaceous was followed by out-of-sequence thrusting in the Late Cretaceous-Paleogene, creating composite thrust sheets consisting both of continental and oceanic units (e.g. Schmid et al., 2008). The vergence of Cretaceous-Paleogene nappe stacking was generally top-SW, which resulted in the burial and accretion of regional thrust sheets, namely the Pelagonian, Pindos, Gavrovo-Tripolitza, and Ionian (e.g. Jolivet and Brun, 2010; van Hinsbergen et al., 2005). The nappe stack was affected by syn-to-post-orogenic extension, which controlled the exhumation of the buried continental crust. The kinematics of extension was generally top- 
NE (with the exeption of Rhodopia, e.g. Brun and Sokoutis, 2007), i.e. the exact opposite of the nappe stacking vergence (e.g. Brun et al., 2016; Walcott, 1998). The opposite-sense shearing made use of pre-existing nappe contacts, and, therefore, mechanical heterogeneities influenced the pattern of rock exhumation (Jolivet et al., 2010) in addition to the changing velocity of slab roll-back, which was responsible for a switch from localized to distributed extension in the Aegean (Brun et al., 2016).

\subsubsection{Tectonic setting of the Betics}

The Betics mountain range is part of the curved Betic-Rif orogenic system in the western Mediterranean (Figure 1.2), which formed as a result of convergence between the North African and Iberian continental margins (e.g. Balanyá and García-Dueñas, 1987; Faccenna et al., 2004; Platt et al., 2003a). Similarly to the Hellenides, continental subductionexhumation processes played a major role in the evolution of the Betics. The mountain range is made up by three, predominantly continental nappe complexes (from bottom to top Nevado-Filábride, Alpujárride, and Malaguide) that were buried in subduction zones to various depths during the Paleogene and Miocene (e.g. Azañón, 1997; Balanyá and GarcíaDueñas, 1987; Booth-Rea et al., 2002; Goffé et al., 1989; Platt et al., 2006; van Hinsbergen et al., 2014). The exhumation of the deepest unit (Nevado-Filábride Complex) was controlled by a major extensional detachment, which led to the formation of an elongated tectonic window exhibiting high-grade metamorphic rocks in the core of the mountain range (Martínez-Martínez and Azañón, 1997; Martínez-Martínez et al., 2002; Platt et al., 1984; Platt and Vissers, 1980). The exposures of the Nevado-Filábride and the structurally overlying Alpujárride Complex have been extensively used to derive the Cenozoic tectonic evolution of the Betics including the mechanism of continental subduction and subsequent exhumation (e.g. Augier et al., 2005a; Behr and Platt, 2012; Booth-Rea et al., 2015; MartínezMartínez et al., 2002). To this end, the paleo-geographic origin and the conditions (e.g. timing) of subduction of the Nevado-Filábride Complex remain debated (e.g. Augier et al., 2005a; Platt et al., 2006), hence inviting further investigations of the geological record in order to further constrain the geodynamic evolution.

\subsection{Scope of the thesis}

The thesis aims to contribute to the understanding of continental burial-exhumation cycles, ultimately to further constrain the geodynamic evolution of convergent plate boundaries as well as plate tectonic reconstructions. In particular, debated or enigmatic questions such as the understanding of successive burial-exhumation cycles related to continent-ocean and subsequent continent-continent convergence or the physical evolution of obduction systems are prime research objectives. The main focus points of the conducted research are (1) to explore the geological (in particular structural and geochronological) record of successive continent-ocean and continent-continent convergence in the Eastern and Western Mediterranean regions (Hellenides and Betics, respectively), and thus constrain the geodynamic evolution of the regions and the mechanics of burial-exhumation processes; (2) 
to improve the understanding of strain localization processes (e.g. the effect of structural inheritance and mechanical stratigraphy) during the burial and exhumation of the continental upper crust; (3) to unravel the significance of continental subduction-exhumation processes during the obduction of ophiolite sheets.

In order to explore a wide range of processes involved during continental burialexhumation cycles, field studies were conducted in two regions of the Mediterranean orogenic system that exhibit different characteristics in terms of structure and metamorphic history; the Northern Sporades (Pelagonian zone) in Greece, and the Sierra de los Filábres (internal Betics) in SE-Spain. The rocks of the Northern Sporades islands are characterized by generally low metamorphic grade and no major jumps of metamorphic grade across tectonic contacts, while the Sierra de los Filábres exhibit high-grade metamorphic (eclogite facies) rocks in its core, separated by a major extensional detachment from the overlying lowgrade metamorphic rocks. The different field regions allowed to conduct case studies focusing on shallow burial and the role of structural inheritance during exhumation (Northern Sporades), as well as deep burial and the link between extensional detachment formation and the extrusion of the subducted continental crust (Sierra de los Filábres). In this research, field studies combined geological mapping, structural analysis, and sample collection for ${ }^{40} \mathrm{Ar} /{ }^{39} \mathrm{Ar}$ dating and petrological investigations. The field and analytical data aims to constrain the superposition of ophiolite obduction and continental subduction in the Northern Sporades (Chapter 2) and in the Betics (Chapter 4), as well as strain localization processes during the burial-exhumation cycle of the continental upper crust (Chapter 3). Following the field studies that constrain the geological record of ophiolite belts, the physical relation between continental subduction-exhumation and ophiolite sheet emplacement is addressed by a thermo-mechanical numerical modelling study, validated against a global geological dataset (Chapter 5).

\subsection{Thesis outline}

Following the introduction, Chapter 2 provides a detailed field-based study from the island of Skopelos (Northern Sporades islands, Pelagonian zone, Greece) that integrates structural and petrological analyses with white mica ${ }^{40} \mathrm{Ar} /{ }^{39} \mathrm{Ar}$ dating in order to delineate phases of tectonic burial and exhumation, and to determine their timing, kinematics, and metamorphic conditions. The combination of the new structural, petrological, and geochronological data with published datasets allows for discriminating between the record of burial-exhumation related to obduction of the Vardar/Neotethys ophiolite sheet, and burial-exhumation related to the subsequent Pelagonia-Rhodopia collision. The defined regional tectonic events are correlated at a large scale, within the Hellenides-Dinarides orogen, and discussed in terms of burial-exhumation mechanics.

The study in Chapter 3 aims to understand strain localization on the scale of the Pelagonian metasedimentary cover formations (Late Paleozoic to Paleogene) on the Northern Sporades (Greece), from the initial stages of Paleogene shortening, through nappe stacking, to extensional exhumation. We apply detailed structural analysis and the ${ }^{40} \mathrm{Ar} /{ }^{39} \mathrm{Ar}$ dating of key shear zones. The study highlights the importance of structural inheritance related to a 
pre-extension shortening phase, as well as of the mechanical stratigraphy in the burialexhumation mechanics of upper crustal formations. We argue that structural inheritance and mechanical stratigraphy were key in defining a distributed extensional deformation pattern during exhumation, dominated by layer-parallel shearing. In addition, the study defines two newly mapped, major thrust contacts on the island of Skiathos.

Chapter 4 focuses on the structural and geochronological record of continental subduction-exhumation processes in the Nevado-Filábride Complex of the Betics mountain range (SE-Spain). We combine previously published datasets with new structural and ${ }^{40} \mathrm{Ar} /{ }^{39} \mathrm{Ar}$ white mica dating results in order to constrain the structural superposition of tectonic units and the timing of continental subduction. Our results indicate two phases of Cenozoic burial in the Nevado-Filábride Complex, which inspire the revision of existing paleo-geographic reconstructions. Our proposed reconstruction accounts for Paleogene obduction of an ophiolite sheet derived from the Alpine Tethys over the continental formations of the Nevado-Filábride Complex, followed by a second phase of Miocene subduction below the Alboran continental domain. The kinematic data constraining Miocene subduction and exhumation implies that the main extensional detachment obliquely cut the inherited nappe stack. These results have significant implications for regional paleogeographic reconstructions.

Chapter 5 focuses on the links between continental subduction-exhumation and ophiolite sheet emplacement. We combine numerical thermo-mechanical simulations of oceanic upper plate-continental lower plate subduction systems and data acquired in ophiolite belts worldwide to unravel the physical processes that explain the structure of ophiolite belts. Our results reveal that buoyancy-driven extrusion of subducted crust triggers necking and breaking of the overriding oceanic upper plate. The broken-off piece of oceanic lithosphere is then transported on top of the continent along a flat thrust segment and becomes a fartravelled ophiolite sheet separated from its root by the extruded continental crust. Our model carries implications for the tectonic evolution of ophiolite belts worldwide as well as for continental subduction-exhumation processes in general.

Chapter 6 provides a short synthesis that combines the results of various thesis chapters in order to gain and discuss broader insights about continental burial-exhumation processes. 


\section{Chapter 2. Cretaceous-Paleogene tectonics of the Pelagonian Zone: Inferences from Skopelos island ${ }^{1}$}

1 This chapter is based on Porkoláb, K., Willingshofer E., Sokoutis, D., Creton, I., Kostopoulos D., Wijbrans J., 2019, Tectonics, 38(6), 1946-1973. 


\subsection{Introduction}

Successive episodes of continent-ocean and continent-continent convergence may result in the repeated tectonic burial and exhumation of a continent or continental block and lead to a complex polyphase deformation history recorded by metamorphic rocks. The Aegean region (Figure 2.1) provides an opportunity to investigate such a succession of events, since episodes of oceanic and continental subduction, obduction, and continentcontinent collision have all taken place during the alpine evolution of the region (Bortolotti et al., 2013; Brun et al., 2016; Goffé et al., 1988; Jolivet and Brun, 2010; Maffione et al., 2015; Robertson, 2004; Schmid et al., 2008). The complexity of the Aegean evolution requires an integrated approach: it has been demonstrated that studies that integrate structural analyses with petrological and/or geochronological investigations can significantly contribute to the understanding of regional geodynamics (e.g. Laurent et al., 2017; Lips et al., 1998; Lips et al., 1999; Philippon et al., 2011; Walcott, 1998).

The Pelagonian zone in Greece (Figure 2.1) records multiple phases of deformation and metamorphism related to continent-ocean and subsequent continent-continent convergence (Kilias et al., 2010; Lips et al., 1998; Most, 2003; Schenker et al., 2014; Schermer et al., 1990; Sharp and Robertson, 2006; Walcott, 1998). Obduction of Jurassic ophiolites from the Neotethys ocean in the Late Jurassic-Early Cretaceous was followed by the collision between Pelagonia and Rhodopia and the subsequent subduction of Pelagonia below Rhodopia in the latest Cretaceous-Paleogene (e.g. Ricou et al., 1998; Schermer et al., 1990; Sharp and Robertson, 2006; Spray et al., 1984). The repeated burial was followed by extensional exhumation adding further to the complexity of the superimposed deformation phases (Brun et al., 2016; Jolivet and Brun, 2010; Walcott, 1998). Consequently, the Pelagonian zone offers many open questions especially regarding the definition of structural units, tectonic transport directions, and the timing and metamorphic grade of deformation events. 


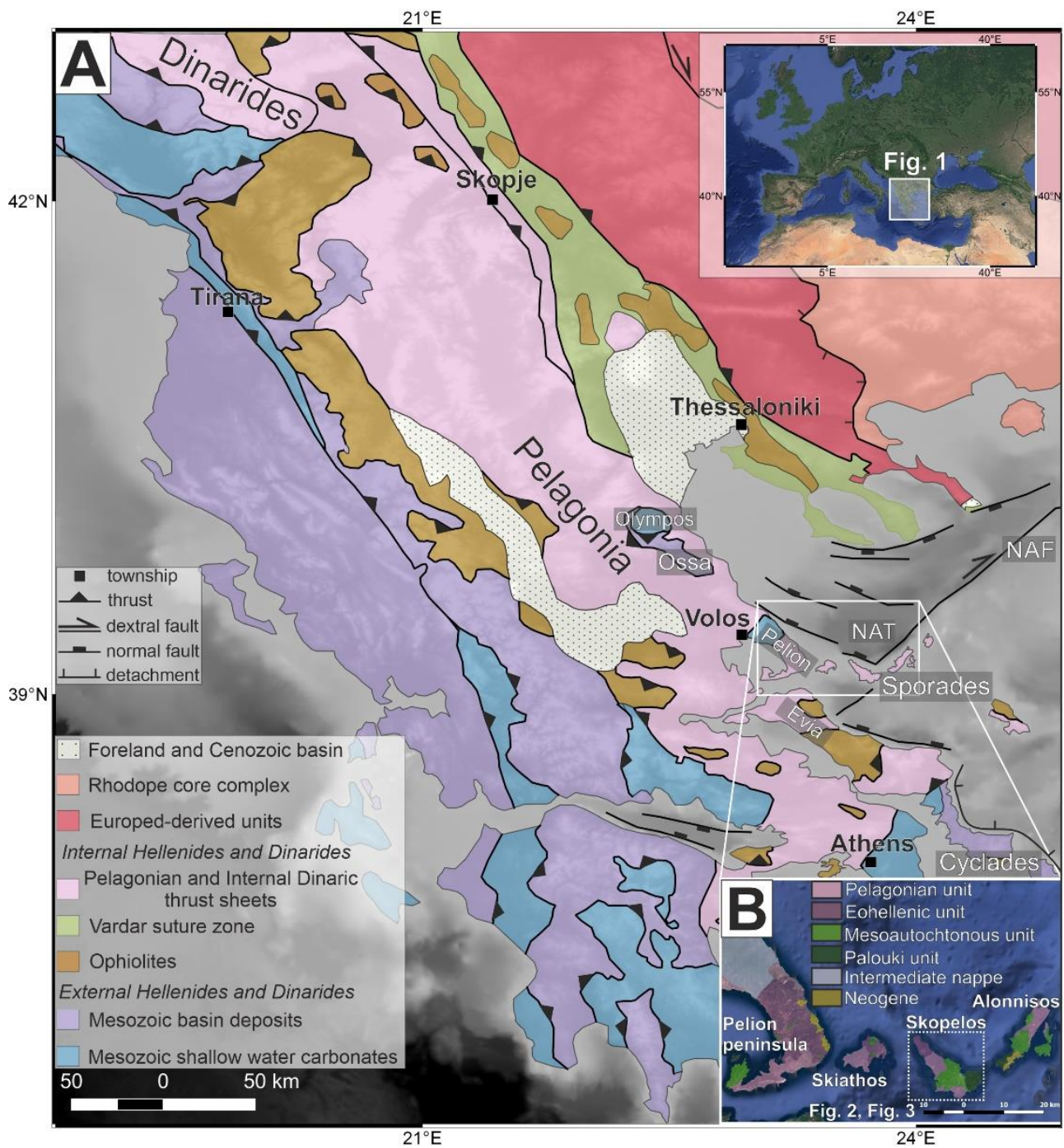

Figure 2.1. (a) Simplified geological map of the Aegean domain showing the main tectonic units and important structures (modified after Burg, 2012). The greyscale background elevation map is based on GMRT data (Ryan et al., 2009). NAF=North Anatolian fault; NAT=North Aegean trough. Location of Figure 2.1b is shown by white bracket. (b) Map showing the main geological units of the Northern Sporades and the Pelion peninsula following the subdivision of Jacobshagen et al. (1978).

In this study, we have investigated the geological record of tectonic burial and exhumation in the eastern part of the Pelagonian zone (Figure 2.1), exposed on the Northern Sporades, an island group in the northern Aegean region.

In particular, we present a field-based study from the island of Skopelos that integrates structural and petrological analyses with white mica ${ }^{40} \mathrm{Ar} /{ }^{39} \mathrm{Ar}$ dating in order to delineate phases of tectonic burial and exhumation and to determine their timing, kinematics, and metamorphic conditions. Comparison of our new data with published data sets allows for 
discriminating between burial-exhumation related to obduction tectonics, and burialexhumation related to the Pelagonia-Rhodopia collision as well as for correlating deformation events within the Pelagonian zone at large scale. We conclude with discussing our new results in the frame of Cretaceous-Paleogene geodynamic processes within the Aegean realm.

\subsection{Geological setting}

\subsubsection{Mesozoic - Paleogene geological evolution of the Pelagonian zone}

The Pelagonian is defined as a NW-SE trending zone in the Republic of North Macedonia and Greece consisting of thrust sheets that record Alpine orogenic events (Aubouin et al., 1976), and is bordered by the Neotethys/Vardar oceanic suture zone in the NE and the external Hellenides (Pindos and Adria) in the SW (Figure 2.1a). The Pelagonian zone is either interpreted as an Adria-derived tectonic unit representing the passive margin that was facing a single Neotethys ocean (e.g. Bortolotti et al., 2005; Mercier et al., 1975; Schmid et al., 2008), or as a microcontinent separated from Adria by the Pindos and from Eurasia by the Vardar oceans (e.g. Dilek et al., 2007; Robertson et al., 1996; Sharp and Robertson, 2006). Late Paleozoic - Early Triassic rifting during the break-up of Pangea and subsequent Early-Middle Triassic spreading led to the formation of a passive margin facing the Neotethys/Vardar ocean within the Pelagonian realm (e.g. Bortolotti and Principi, 2005; Stampfli and Borel, 2002). Rifting and marine invasion was reflected in the deposition of Permian and Early Triassic syn-and post-rift sediments on top of the Variscan basement, and extensive deposition of carbonate platform sediments from Middle Triassic to Middle Jurassic times (e.g. De Bono, 1998; De Bono et al., 2001; Scherreiks et al., 2010). Upper Paleozoic - Early Triassic (meta)clastic deposits together with thick Pelagonian carbonates of Triassic and Jurassic age characterize a significant part of the Pelagonian zone, including the Sporades and the Pelion peninsula (Figure 2.1b). Deep water sediments and volcanicsedimentary mélange successions of similar age are found in the same area (De Bono, 1998; Jacobshagen and Wallbrecher, 1984; Sharp and Robertson, 2006). A similar volcanicsedimentary succession on the Sporades called the "Eohellenic unit" consists of clastic metasediments, thin-bedded marbles, and mafic metavolcanics of unknown stratigraphic range (Jacobshagen and Matarangas, 2004; Jacobshagen et al., 1978; Jacobshagen and Wallbrecher, 1984; Matarangas, 1992). The Pelagonian carbonate platforms drowned in the Middle-Late Jurassic as marked by deposits of reef debris carbonates intercalated with nodular cherty carbonates. Late Jurassic radiolarites and greywackes are found in the upper members of the deepening sequence (Danelian and Robertson, 2001; Robertson, 1991; Scherreiks, 2000).

The Permian-Jurassic sedimentary succession of the Pelagonian zone is overlain by obducted ophiolitic rocks that originated in the Neotethys ocean. The ophiolites probably formed in a supra-subduction zone setting following intra-oceanic subduction initiation (Barth et al., 2008; Clift and Dixon, 1998; Maffione et al., 2015). Middle -Late Jurassic radiometric ages of the metamorphic sole at the base of the ophiolitic nappe attest to the early phases of intra-oceanic obduction (Bortolotti et al., 2013; Clift and Dixon, 1998; Dilek et al., 
2007; Dimo-Lahitte et al., 2001; Liati et al., 2004; Maffione et al., 2015; Robertson, 2004). Intra-oceanic obduction was followed by the emplacement of the ophiolitic thrust sheet(s) onto the Pelagonian passive margin leading to deformation and metamorphism in the Pelagonian zone. This Late Jurassic - Early Cretaceous tectono-metamorphic event of various metamorphic grade (greenschist facies to partial melting) has been reported from various locations along the Pelagonian zone as well as in the Dinarides providing evidence for the tectonic burial of the passive margin following ophiolite obduction (e.g. Kilias et al., 2010; Lips et al., 1999; Most, 2003; Schefer, 2012; Schenker et al., 2014; Schermer et al., 1990; Schmid et al., 2008; Sharp and Robertson, 2006; Tomljenović et al., 2008; Walcott, 1998).

The burial of the Pelagonian margin was followed by exhumation and the formation of a regional Late Jurassic - Early Cretaceous erosional unconformity in the Evia-PelionSporades region (De Bono, 1998; Jacobshagen and Wallbrecher, 1984). Karstification of the Pelagonian carbonates was associated with the accumulation of bauxites and laterites (e.g. Jacobshagen and Wallbrecher, 1984; Robertson, 1991). Deposition of Albian-Turonian transgressive conglomerates, carbonates, and finally Turonian - Paleogene flysch marks Late Cretaceous transgression and the evolution of a foredeep, which in all likelihood marks the final closure of the Neotethys/Vardar ocean between Pelagonia and Eurasia (Jacobshagen and Wallbrecher, 1984). This Upper Cretaceous - Paleogene sedimentary sequence is referred to as Mesoautochtonous unit (Jacobshagen and Wallbrecher, 1984). A stratigraphically similar but structurally distinct succession is called the Palouki unit which crops out on Skopelos and Alonnisos (Figure 2.1b). The Mesoautochtonous and the Palouki unit have experienced low-grade metamorphism and intense deformation due to the final closure of the Neotethys ocean and following nappe stacking, which is assumed to be of Eocene in age based on the age of the Flysch formations (Jacobshagen and Wallbrecher, 1984; Matarangas, 1992). Similar tectono-metamorphic events ranging from Late Cretaceous to Late Paleogene in time and greenschist to blueschist facies metamorphism have been reported from many locations within the Pelagonian zone (e.g. Lips et al., 1999; Schermer et al., 1990; Walcott, 1998) and also from the more external domains of the Hellenides like the Cyclades (e.g. Altherr et al., 1979; Blake et al., 1981; Bröcker et al., 1993; Lister and Forster, 2016; Wijbrans et al., 1990). Final closure of the Neotethys/Vardar ocean resulted in regional nappe stacking and the formation of the generally SW-verging Hellenides (Figure 2.1a) with metamorphic rocks in the lower tectonic units like Pelagonia, Pindos, and Adria experiencing largely top-SW sense of shear (Brun et al., 2016; Jolivet and Brun, 2010). Subduction of continental crust such as Pelagonia might have contributed significantly to the initiation of slab-rollback (Brun and Faccenna, 2008) which has controlled upper plate extension and exhumation in the Aegean by detachment systems with mainly top-NE kinematics since Paleogene times (Brun et al., 2016; Brun and Sokoutis, 2007; Gautier and Brun, 1994).

\subsubsection{Geology of Skopelos}

The island of Skopelos belongs to the Northern Sporades, a group of islands located ca. $100 \mathrm{~km}$ north of Athens, due east of Volos and which are part of the Pelagonian zone. In the following paragraphs, we will describe the structure and stratigraphy of Skopelos island from bottom to top, following the subdivision of Matarangas (1992). The lowermost unit is the 
Pelagonian, which consists of Upper Paleozoic - Carnian mixed metaclastic-carbonate (thinbedded marble) succession and conformably overlying Carnian - Jurassic (?) thick- bedded carbonates (marbles and dolomites) (Matarangas, 1992). Jurassic carbonates in the Pelagonian unit have been reported from the neighboring island of Alonnisos (Figure 2.1b) (Kelepertsis, 1974), however these observations have not been confirmed from Skopelos yet. The Glossa unit structurally overlies the Pelagonian unit (Matarangas, 1992). It is mainly a metasedimentary-metavolcanic succession consisting of phyllites, metasandstones, thinbedded marbles that contains slices of metabasalts and Cipolines (pale green marbles with tuff content (Matarangas, 1992). The stratigraphic age of the Glossa unit is uncertain as is its provenance. This unit has been interpreted as part of the Pelagonian unit based on lithological similarities (Jacobshagen et al., 1978), or as part of the Eohellenic nappe, which represents the transition from the distal Pelagonian margin towards the Neotethys/Vardar ocean (Jacobshagen and Matarangas, 2004; Matarangas, 1992). The latter interpretation implies that the Glossa and the Pelagonian units on Skopelos are time equivalents (Upper Paleozoic - Jurassic). According to Matarangas (1992), the Glossa unit has been thrust on top of the Pelagonian probably in Early Cretaceous times when the Jurassic ophiolites of the Neotethys ocean were emplaced on top of the Pelagonian zone. Both the Pelagonian and the Glossa units record low-grade metamorphism and pervasive folding (Matarangas, 1992). 


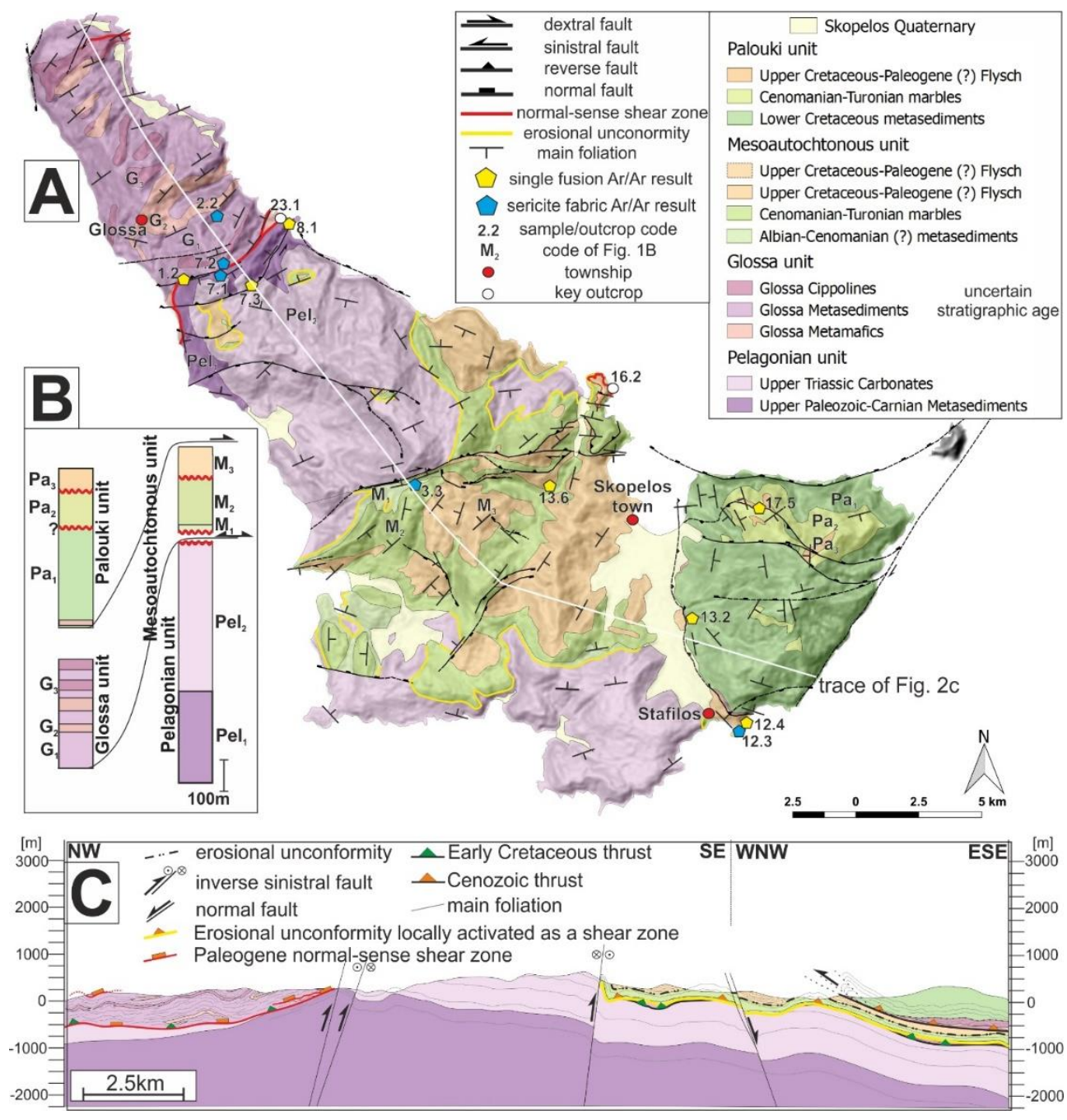

Figure 2.2. (a) Geological map of Skopelos (modified after Matarangas, 1992) showing the major structures, measurements of the main foliation, and important locations on the island. (b) Tectonostratigraphic column showing the approximate outcropping thickness of the formations. (c) Cross section through Skopelos island. Trace of the cross section is shown on Figure 2.2a by white line.

The Pelagonian and Glossa units are truncated by an erosional unconformity, which forms the base of the younger sedimentary cycle, the Mesoautochtonous unit. The unconformity is marked by metabauxites and Al-rich metapelites which mainly fill the uneven karstified surface of the Pelagonian dolomites on Skopelos (Figure 2.2) as well as the Glossa unit on Skiathos (Figure 2.1b). Petrological analysis of the Al-rich metapelites has shown the occurrence of carpholite and chloritoid which implies high pressure metamorphic conditions (Mposkos and Liati, 1991a). The metabauxites and metapelites are considered to be of Albian age (Matarangas, 1992), however different Late Jurassic - Early Cretaceous ages cannot be ruled out due to the time range of the regional hiatus (e.g. Robertson, 1991). 
On top of the metabauxites-metapelites, Albian-Cenomanian transgressive conglomerates occur, which are gradually pass to Cenomanian-Turonian carbonates. The carbonates exhibit well-foliated, rudist-bearing marbles as well as massive dolomitic layers with barely visible foliation. The carbonates are unconformably overlain by a largely fine-grained metaclastic succession, the Mesoautochtonous Flysch unit. The age of the flysch was described as Maastrichtian - Paleogene (Matarangas, 1992). Fossils found in the flysch confirm the extent of this formation into the Paleocene and possibly into the Eocene (Matarangas, 1992). The entire Mesoautochtonous sequence experienced low-grade metamorphism and pervasive deformation (Jacobshagen and Wallbrecher, 1984; Matarangas, 1992).

Skopelos exhibits another tectonic unit with similar Cretaceous strata: the Palouki unit (Figures 2.1b and 2.2). This unit lies on top of the Mesoautochtonous unit separated by a thrust (Figure 2.2). It consists of three formations. The upper two formations are equivalents of the marbles and the overlying flysch of the Mesoautochtonous unit; they share lithological and stratigraphic characteristics (Cenomanian - Turonian marbles and Upper Cretaceous Paleogene flysch) (Matarangas, 1992). In contrast, the lowest and thickest formation of the Palouki unit is uncertain in age and is lacking equivalents in the region. It largely consists of fine-to medium-grained metaclastic sediments and thin-bedded marbles. Based on the lithofacies, a deep-water origin was proposed for the lowest Palouki formation (Matarangas, 1992). Its contact with the overlying Cenomanian-Turonian carbonates is uncertain; it could either be conformable or erosional (Matarangas, 1992). The base of the formation and thus of the whole Palouki unit exposes mafic volcanic bodies, fine-grained dark phyllites, and serpentinite blocks. Based on these findings, it was assumed that the Palouki unit was deposited on the Eohellenic nappe (Glossa unit on Skopelos) (Matarangas, 1992). Fossils are scarce and document an Upper Jurassic - Lower Cretaceous stratigraphic range (Matarangas, 1992). The Palouki nappe experienced low-grade metamorphism and pervasive deformation similar to the Mesoautochtonous unit (Matarangas, 1992).

\subsection{Analytical methods}

\subsubsection{Microprobe analyses for pressure-temperature calculations}

Microprobe analyses were performed in order to constrain the chemical composition and gain the input for thermodynamic calculations of a prospective shear zone (outcrop 3.3 on Figure 2.2a). The microprobe analyses were conducted at the Department of Geological Sciences, School of Mining and Metallurgical Engineering, National Technical University of Athens, Greece, using a JEOL JSM-6380LV scanning electron microscope equipped with an EDS Oxford Instruments INCA 505 analytical system. Operating conditions were: accelerating voltage $20 \mathrm{kV}$, beam diameter $1 \mu \mathrm{m}$, probe current $20 \mathrm{nA}$ and counting time 80 s. Standards used were: wollastonite $(\mathrm{Si}, \mathrm{Ca})$, rutile $(\mathrm{Ti})$, corundum $(\mathrm{Al})$, hematite $(\mathrm{Fe})$, rhodonite $(\mathrm{Mn})$, periclase $(\mathrm{Mg})$, jadeite $(\mathrm{Na})$ and orthoclase $(\mathrm{K})$. Results of the analyses are listed in Appendix, and the P-T estimations based on the results are given in Section 4.3. 


\subsection{2 ${ }^{40} \mathrm{Ar} /{ }^{39} \mathrm{Ar}$ dating}

${ }^{40} \mathrm{Ar} /{ }^{39} \mathrm{Ar}$ dating of white micas was performed with the objective to link deformation phases recorded by the metamorphic rocks exposed on Skopelos with thermal and/or crystallization events. It has been demonstrated that conventional multi-grain step heating ${ }^{40} \mathrm{Ar} /{ }^{39} \mathrm{Ar}$ dating of mixtures of white micas (Schermer et al., 1990) as commonly occur in the blueschist-greenschist domain may result in geologically meaningless age spectra without knowing the precise end-members of the mixture (Bröcker et al., 2013; Lister and Forster, 2016). Warren et al. (2012a) made the point that under such PT conditions muscovites or phengites may yield crystallization ages meaning that resetting is not achieved by thermally activated diffusion. To avoid difficulties in interpretation and gain the maximum information from our samples, we applied two ways of ${ }^{40} \mathrm{Ar} /{ }^{39} \mathrm{Ar}$ dating: 1) determination of the ${ }^{40} \mathrm{Ar} /{ }^{39} \mathrm{Ar}$ age of fine-grained mylonitic foliations by step heating experiments on fine-grained sericite fabrics $\left(S_{2}\right.$ on Figures $2.5 b, c$, d, and e) 2) determination of the ${ }^{40} \mathrm{Ar} /{ }^{39} \mathrm{Ar}$ age of larger $(\geq 250 \mu \mathrm{m})$ white mica crystals with the multiple single grain fusion dating method (Figures 2.5a and f). The applicability of white mica ${ }^{40} \mathrm{Ar} /{ }^{39} \mathrm{Ar}$ fabric and single grain fusion dating approach for the detection of multiple tectonic events has been proven by several works as well as that careful microstructural characterization of the samples allows for selective dating of different foliations (Beltrando et al., 2009; Lips et al., 1998; Lister and Forster, 2016; Uunk et al., 2018; Wijbrans et al., 1990). Thus, by the combined usage of fabric and single grain fusion methods we may expect to gain time constraints for multiple main stages of ductile deformation on Skopelos. A short description of the dated samples is given in Appendix 3.

In case of the fine-grained sericite fabrics we used groundmass separates because individual sericite grains were too small for separation. The grain size of the groundmass separates was $250-500$ micrometer. The methodology of ground mass dating followed Pascual et al. (2013).

For the purpose of single grain fusion dating white mica crystals of the crushed samples were separated from $250-500 \mu \mathrm{m}$ sieve fractions using a Faul vibrating table and heavy liquid density-based separation. Carbonate and dust contamination were removed by HNO3 treatment of the samples. Mica separates from 7 samples were selected for single grain fusion dating. The samples were packed in aluminium foil packages and stacked in an aluminium tube that was irradiated for $18 \mathrm{hrs}$. in the CLICIT facility of the Oregon State University TRIGA Reactor. For both irradiations the neutron flux was monitored by standard bracketing with the DRA sanidine standard with an age of $25.52 \pm 0.08 \mathrm{Ma}$, modified from Wijbrans et al. (1995) to be consistent with Kuiper et al. (2008).

Single grain fusion and step heating experiments were carried out in the Vrije University Amsterdam argon geochronology laboratory with $25 \mathrm{~W}$ CO2 laser heating samples loaded on Cu-trays (185 individual $2 \mathrm{~mm}$ diameter, $3 \mathrm{~mm}$ deep holes for single grains and $6 \mathrm{~mm}$ diameter holes for the incremental heating of fine sericite. The sample holder was connected to a three-stage extraction line and a quadrupole mass spectrometer (Schneider et al., 2009). Data was reduced in ArArCalc 2.50 (Koppers, 2002). Procedure blanks were monitored and diluted air shots were measured in the sequence to track mass discrimination. 


\subsection{Results}

\subsubsection{Structural mapping and kinematics of ductile deformation}

Field work has been conducted with the aim of inferring the kinematics and relative sequence of deformation phases that are associated with the burial and the exhumation of rocks exposed on the island of Skopelos. As such our fieldwork entailed a detailed mapping of ductile structures including foliation planes and related stretching lineations and shear sense indicators (Passchier and Trouw, 1996; Simpson and Schmid, 1983) as well as fold structures. Structural mapping was done on the basis of the geological map of Skopelos (Matarangas, 1992) and led to the revision of the map on some fault structures and their kinematics (Figure 2.2), a detailed discussion of which is beyond the scope of this contribution. The field data are summarized in map and cross-sectional view (Figures 2.2a, b, and Figures 2.3a, b, and c) as well as in stereographic projections (Figures 2.3d and e). Based on overprinting relations, the mapping of ductile fabrics yielded two distinct deformation phases, which are related to two different burial and exhumation cycles.

$\mathrm{D}_{1}$ deformation phase consists of structures that have been observed in the Pelagonian and Glossa units as well as in the lowermost formation of the Palouki unit. However, $\mathrm{D}_{1}$ structures are absent in the younger sedimentary cycle (Mesoautochtonous unit and in the upper formations of the Palouki unit). The remnants of a first generation of tight-isoclinal folds $\left(\mathrm{F}_{1}\right)$ and an associated axial planar cleavage $\left(\mathrm{S}_{1}\right)$ are preserved in many outcrops (Figure $2.4 \mathrm{c}$ and $\mathrm{d}$ ) and some of our samples (Figures 2.5a, d, and e). $\mathrm{S}_{1}$ foliation planes and $\mathrm{L}_{1}$ stretching lineations are defined by white mica, chlorite, and calcite. Fold axes of $F_{1}$ tightisoclinal, cylindrical folds are mainly trending NE-SW and have both NW and SE vergence (Figures $2.3 \mathrm{c}$ and e). In a few occasions $\mathrm{F}_{1}$ sheath folds have been observed implying intense non-coaxial ductile shear (Figure 2.4a). In outcrops that exhibit $S_{1}$ foliation surfaces, $L_{1}$ stretching lineations were identified, showing approximately NW-SE trends (Figure 2.3a). Associated kinematic indicators show both top-NW and top-SE sense of shear in agreement with the double vergence (NW and SE) of $F_{1}$ tight-isoclinal folds. $D_{1}$ structural features are generally not bound to major shear zones, but are within the Pelagonian, Glossa, and the lowermost formation of the Palouki units. However, the distribution is not homogenous; NWSE stretching lineations and associated top-NW - and SE shear sense indicators are the most abundant in the Upper Paleozoic - Carnian metasediments of the Pelagonian unit (Figures $2.3 \mathrm{a}$ and $\mathrm{b}$ ). No convincing overprinting relations between the top-NW and top-SE shearing has been observed, probably due to the strong post- $\mathrm{D}_{1}$ overprint. 


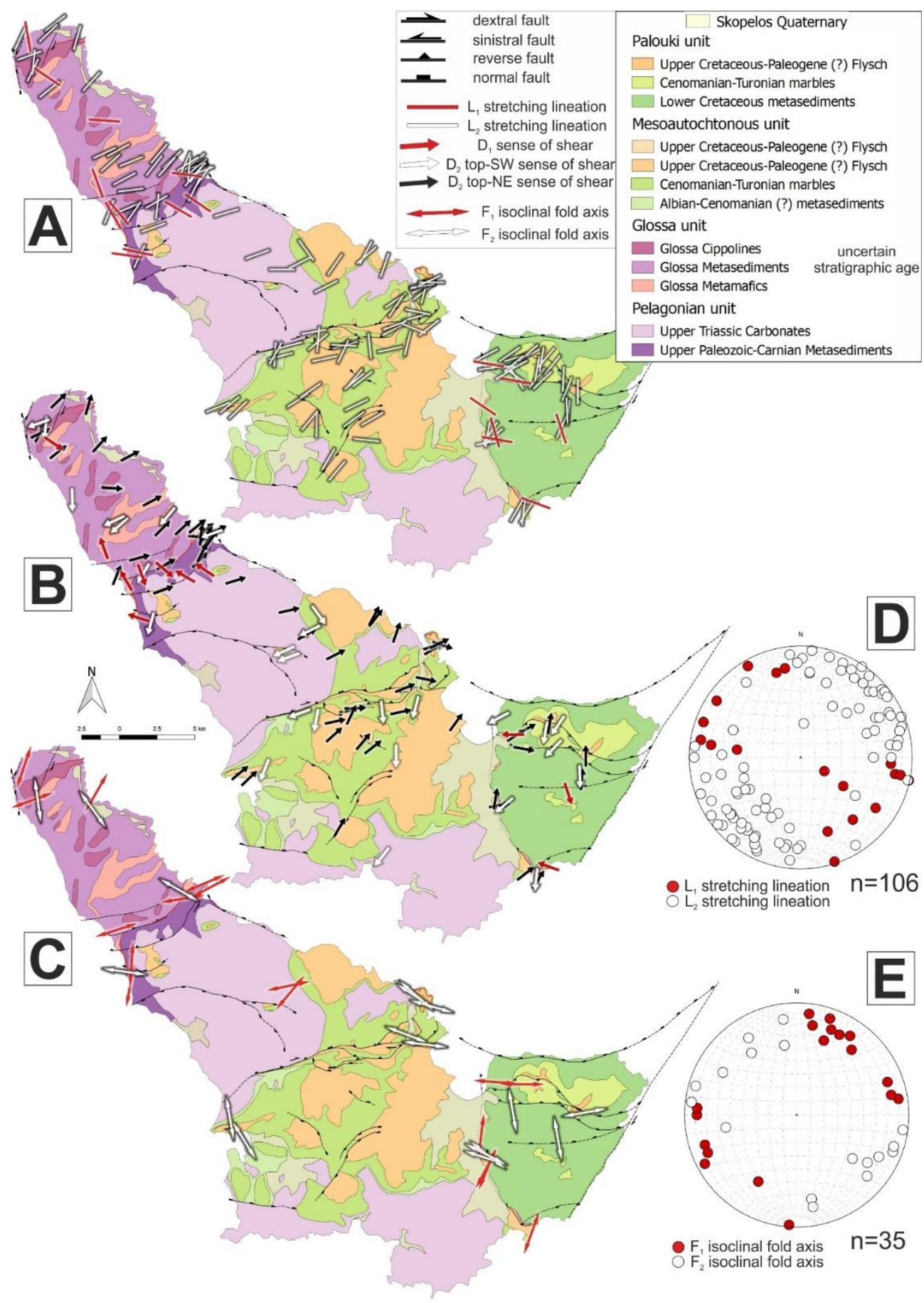

Figure 2.3. Plots of key structural measurements on Skopelos. (a) Map of stretching lineations (b) Map of stretching lineations associated with kinematic indicators. (c) Map of isoclinal fold axes. (d) Stereographic projection of stretching lineations. (e) Stereographic projection of isoclinal fold axes. 

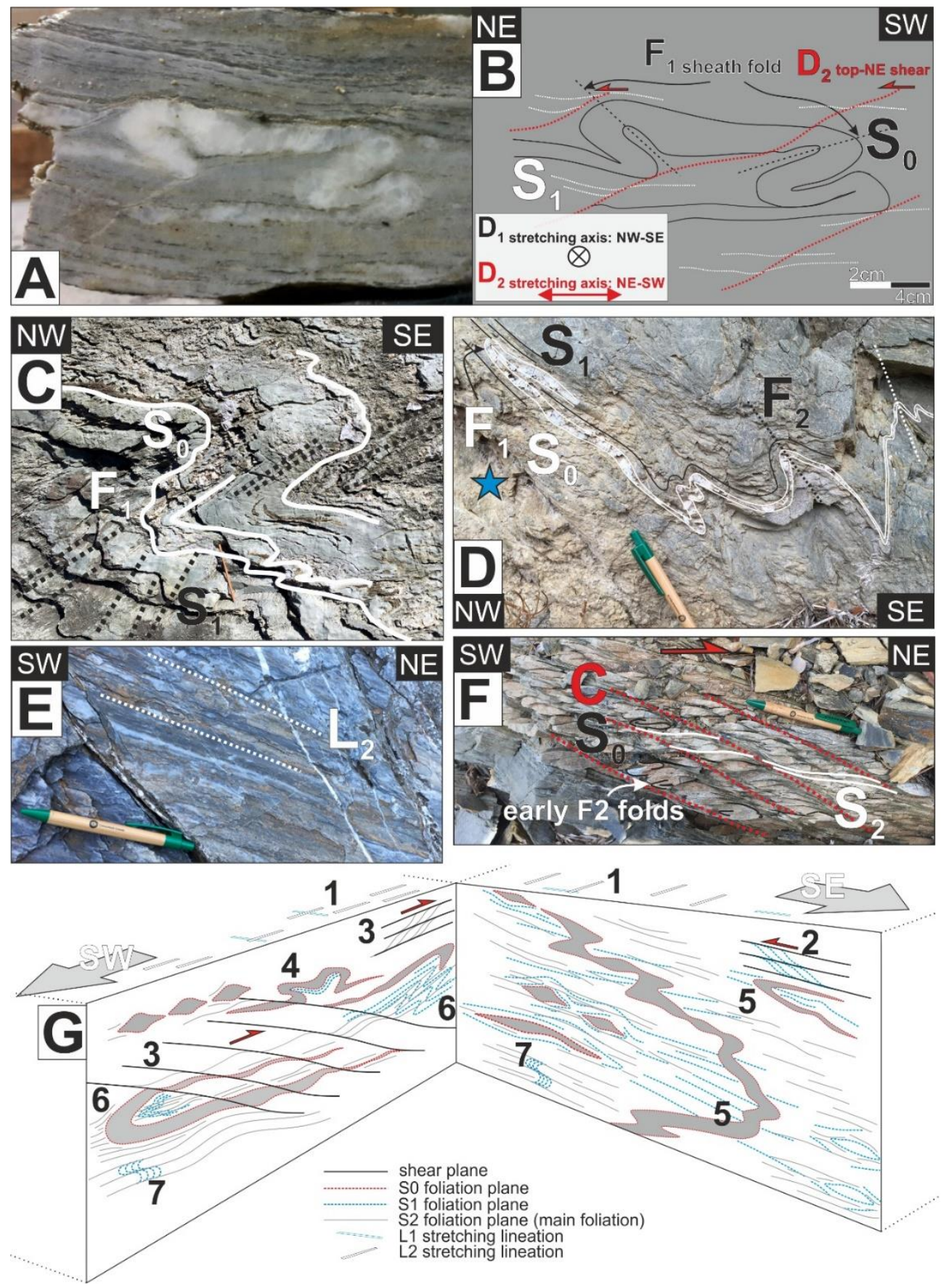

Figure 2.4. Structural interpretation of key observations. (a) and (b) Photo and related drawing of a NW-SE trending sheath fold overprinted by top-NE C-prime shear bands in the Glossa unit. The sections are parallel with the L2 stretching lineation. (c) SE-verging F1 isoclinal fold with well-preserved S1 axial planar cleavage in the Pelagonian unit. The section is parallel with the L1 stretching lineation. (d) Isoclinal F1 fold refolded by close to tight F2 folds at location 13.2 (for 
location see Figure 2.2a). Blue star represents the location of sample 13.2 used for $40 \mathrm{Ar} / 39 \mathrm{Ar}$ single grain fusion dating (Figure 2.8). The section is parallel with the L1 stretching lineation. (e) NE-plunging L2 stretching lineation in the marbles of the Glossa unit. (f) Top-NE C-S fabric in the Upper Cretaceous - Paleogene flysch of the Mesoautochtonous unit. Note that the early D2 isoclinal folds are cut by the shear planes. The section is parallel with the L2 stretching lineation. (g) Idealized NE-SW and NW-SE sections showing the typical structures observed in the Pelagonian, Glossa, and the basal formation of the Palouki units. 1: Scarce NW-SE plunging L1 stretching lineations and dominant NE-SW plunging L2 stretching lineations (Figure 2.3a and d). 2: top-NW shear criteria (Figure 2.3b). 3: top-NE shear criteria (Figure 2.3b). 4: section of noncylindrical F1 fold (sheath fold) (Figure 2.4a and b). 5: remnants of tight-isoclinal F1 folds with either NW or SE vergence. In the hinge zones of these folds the S1 foliation is well-preserved (Figure 2.4c), otherwise obliterated by the pervasive S2 foliation. 6: F2 folds folding both S0 and S1 foliations (Figure 2.4d). 7: S1 foliation crenulated by the S2 foliation (Figure 2.5a).

$\mathrm{D}_{2}$ structures, which overprint $\mathrm{D}_{1}$ structures (Figures 2.4a, b, d, and g, Figures 2.5a, d, and e) are more abundant, are found in many outcrops and in all geological units of Skopelos. The $D_{2}$ phase was characterized by the formation of a pervasive foliation $\left(S_{2}\right)$ defined by fine-grained white mica, chlorite, solution surfaces, and in case of marbles calcite (Figure 2.5). $S_{2}$ corresponds to the axial planar cleavage of tight-isoclinal $F_{2}$ folds that trend NW-SE and have both SW and NE vergence (Figures 2.3c and e, Figure 2.4g, Figure 2.5a). In the Pelagonian and Glossa units, as well as in the lowermost formation of the Palouki unit, $\mathrm{F}_{2}$ structures fold the $S_{1}$ tectonic foliation (Figures $2.4 \mathrm{~d}$ and g, Figures $2.5 \mathrm{a}$ and d), while in the Mesoautochtonous unit and in the upper formations of the Palouki unit $\mathrm{F}_{2}$ structures fold the $\mathrm{S}_{0}$ bedding. Rare occurrences of NE-SW trending $\mathrm{F}_{2}$ non-cylindrical sheath folds are confined to zones of localized ductile strain. $\mathrm{S}_{2}$ foliation planes exhibit strong stretching lineations observed on calcite (Figure 2.4e), white mica, and chlorite, trending NE-SW (measured in more than 80 outcrops) (Figures 2.3a and d). Associated kinematic indicators show the dominance of top-NE shear sense (Figures $2.3 \mathrm{~b}$ and $4 \mathrm{f}$ ), but a significant number of top-SW shear sense indicators have also been found (Figures $2.3 \mathrm{~b}, 2.5 \mathrm{~b}$ and $\mathrm{d}$ ). $\mathrm{D}_{2}$ structures also show largely distributed pattern, however several tectonic contacts have been found with localized ductile deformation related to top-NE or top-SW tectonic transport (Figure 2.6). The $\mathrm{S}_{2}$ main foliation and $\mathrm{F}_{2}$ isoclinal folds are in most cases bent or cut by topNE shear bands (Figure 2.4f) or shear zones that are observed to be gradually replaced by semi-brittle to brittle normal faults (Figure 2.6c). These observations suggest that the early $\mathrm{D}_{2}$ phase is characterized by isoclinal folding $\left(\mathrm{F}_{2}\right)$ and the formation of the main foliation $\left(\mathrm{S}_{2}\right)$ and top-SW shearing (Figure $2.5 \mathrm{~b}$ and $\mathrm{c}$ ), which is followed by top-NE shearing (late $\mathrm{D}_{2}$ ) (Figure 2.4f and $\mathrm{g}$ ). Top-NE shearing is the last phase of ductile deformation we have observed on the island. The description and discussion of the newly established fault pattern (Figure 2.2a) is out of the scope of present contribution. 

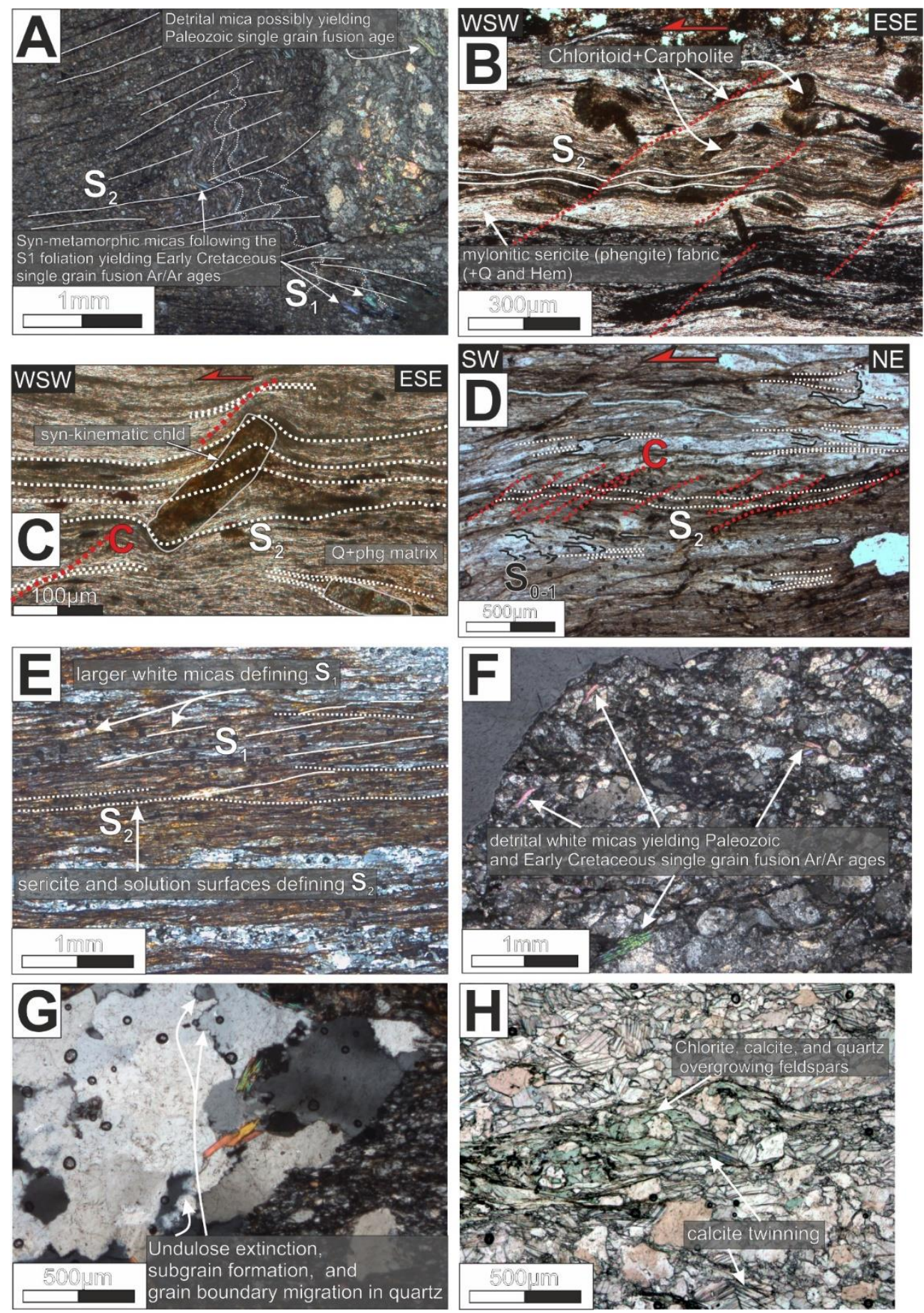

Figure 2.5. Interpretation of microscope images. Images from (a) to (g) were captured with crosspolarized light, image (h) was captured with plain-polarized light. For sample locations see Figure 2.2a. (a) Photo of sample 8.1 highlighting the two tectonic foliations $\left(S_{1}\right.$ and $\left.S_{2}\right)$ present in the 
Pelagonian unit and the larger $(\geq 200 \mu \mathrm{m})$ white mica crystals which were picked for ${ }^{40} \mathrm{Ar} /{ }^{39} \mathrm{Ar}$ single grain fusion dating (Figure 2.8). Note that the majority of the micas define the $S_{1}$ foliation and thus associated to $\mathrm{D}_{1}$ deformation, but some grains of detrital origin also occur. The section is parallel with the $\mathrm{L}_{2}$ stretching lineation. (b) Photo of sample 3.3 showing the mylonitic $\mathrm{S}_{2}$ foliation developed during top-WSW shearing. Chloritoid porphyroblasts contain remnants of carpholite and are swimming in a matrix of phengite, quartz, and hematite. This sample was used for P-T calculations (Figure 2.7) and for ${ }^{40} \mathrm{Ar} /{ }^{39} \mathrm{Ar}$ fabric dating (sample 3.3 on Figure 2.9). The section is parallel with the $\mathrm{L}_{2}$ stretching lineation. (c) Photo of sample 3.3 showing a synkinematic chloritoid porphyroblast with respect to top-WSW shearing. The section is parallel with the $\mathrm{L}_{2}$ stretching lineation. (d) Photo of sample 7.2 from the Glossa unit showing the remnants of the disrupted $S_{0-1}$ foliation folded into tight-isoclinal folds, and the main $S_{2}$ foliation defined by very fine-grained sericite (for ${ }^{40} \mathrm{Ar} /{ }^{39} \mathrm{Ar}$ fabric age of this sample see Figure 2.9) and dissolution surfaces. Top-SW C'-type shear bands developed during and/or after the formation of the $\mathrm{S}_{2}$ foliation. The section is parallel with the $\mathrm{L}_{2}$ stretching lineation. (e) Photo of sample 7.1 from the Pelagonian unit showing $S_{1}$ foliation defined by larger white micas $(\geq 200 \mu \mathrm{m})$ and $S_{2}$ foliation defined by fine grained sericite and solution surfaces (for ${ }^{40} \mathrm{Ar} /{ }^{\beta 9} \mathrm{Ar}$ fabric age of this sample see Figure 2.9) The section is parallel with the $L_{2}$ stretching lineation. (f) Photo of sample 7.2 from the Mesoautochtonous flysch unit showing detrital white mica crystals which were used for ${ }^{40} \mathrm{Ar} /{ }^{39} \mathrm{Ar}$ single grain fusion dating. (g) Photo of sample $1.2 \mathrm{~b}$ from the Glossa unit showing the dynamic recrystallization of quartz. (h) Photo of sample 19.1 from the metabasalts of the Glossa unit showing extensive growth of chlorite and calcite at the expense of the original basaltic mineral assemblage. 

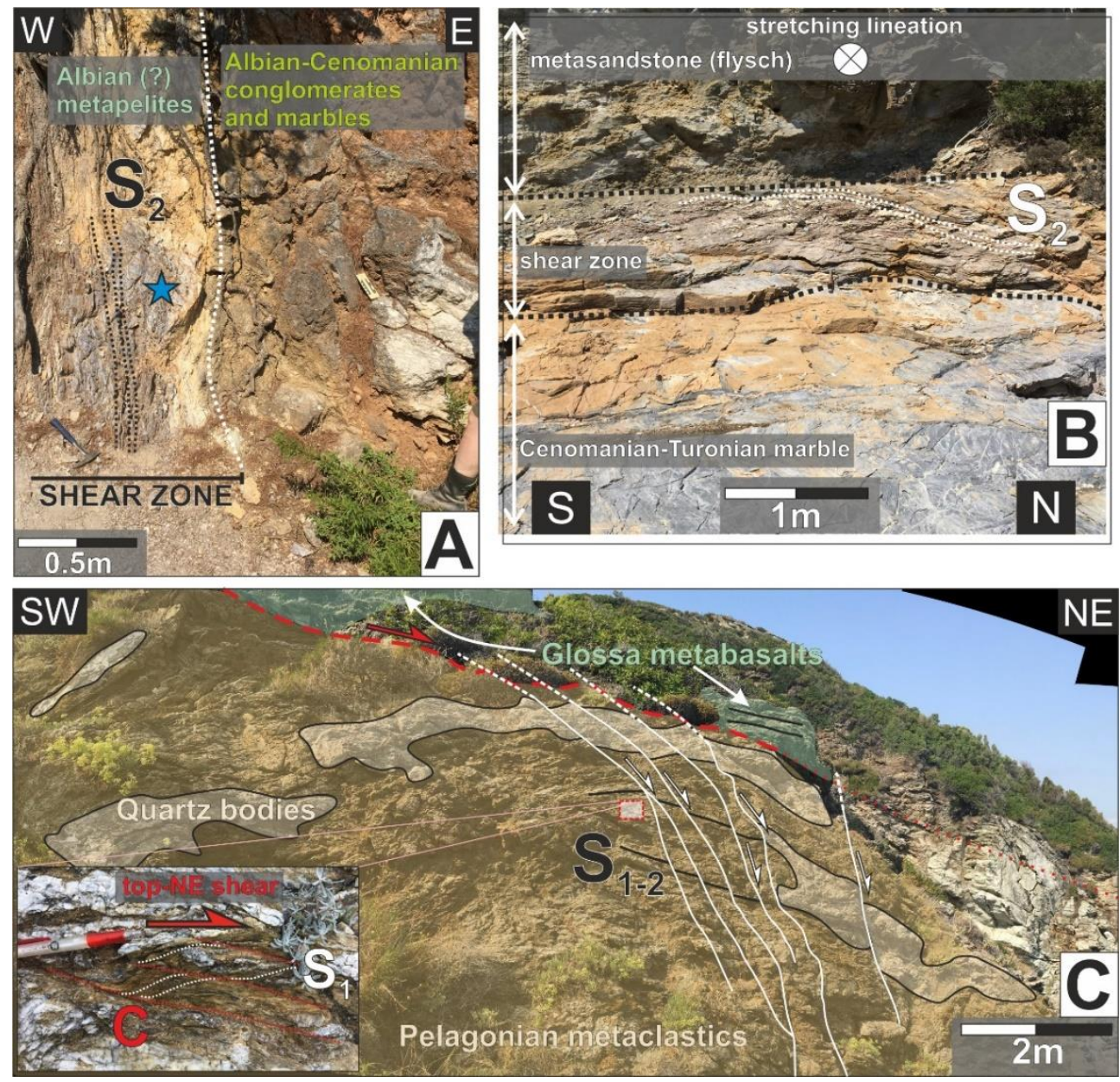

Figure 2.6. Interpretation of key outcrops. For outcrop locations see Figure 2.2a. (a) Shear zone at location 3.3 in Al-rich metapelites separating the Pelagonian and Mesoautochtonous units. Blue star represents the location of the sample used for P-T calculations (Figure 2.7) and ${ }^{40} \mathrm{Ar} /{ }^{39} \mathrm{Ar} \mathrm{S}_{2}$ fabric dating (Figure 2.9). (b) Top-E shear zone localized at the stratigraphic contact between the Cenomanian-Turonian marbles and Upper Cretaceous-Paleogene Flysch of the Mesoautochtonous unit at outcrop 16.2. Note that the shear zone is sub-parallel with the mylonitic $\mathrm{S}_{2}$ foliation. (c) Contact between the Pelagonian and the Glossa units at location 23.1. The contact is characterized by well-developed metamorphic foliation, intense and clear NE-SW trending stretching lineation, top-NE ductile shear, thick bodies of secondary quartz, and late-stage normal faults which cut through the sheared contact.

\subsection{2 $\mathrm{D}_{2}$ shear zones}

Figure 2.6c shows the only clear outcrop (outcrop 23.1, for location see Figure 2.2a) exhibiting the contact between the Pelagonian and the Glossa units. There, pervasive NE-SW trending stretching lineations with top-NE sense of shear as indicated by C-S structures 
(Figure 2.6c) are observed, as well as thick veins and bodies of secondary quartz and intense folding. The deformation is largely accommodated in the Pelagonian metaclastic rocks below the contact delineating a 8-15 m thick zone of localized ductile deformation. The ductile fabric of the shear zone is cut by a series of semi-brittle to brittle normal faults dipping to the North showing a gradual change in the style of extensional deformation from ductile shearing to normal faulting (Figures 2.6c).

Note that the top-NE shear zone has been tilted towards the NW due to a series of brittle, oblique strike-slip/reverse faults during a younger stage of deformation resulting in a NESW orientation of the shear zone in map view (Figures 2.2a and c).

We also found that $\mathrm{D}_{2}$ deformation often localized within narrow (1-10 m thick) shear zones, which are either parallel to the stratigraphic layering (Figure 2.6b or see Figures 2.2a and $\mathrm{c}$ for map-view) or reactivated already existing tectonic contacts (Figure 2.6c). The sense of shear within these shear zones is top-NE or top-E. $\mathrm{A} \mathrm{D}_{2}$ tectonic contact has also been found at the base of Mesoautochtonous unit separating the Pelagonian unit from the Cenomanian-Turonian basal conglomerates and marbles (Figure 2.6a). The shear zone consists of very fine grained, foliated, high-Al metapelites. The metapelites exhibit intense ductile deformation; they have a very closely spaced foliation and a top-WSW C'-type shear bands (Figure 5b). In contrast, the conglomerates and marbles show no enhanced stretching or layer-perpendicular shortening. The subvertical orientation of the foliation and the shear zone is due to late-stage fault-related folding caused by a transpressive fault running at a distance of roughly $100 \mathrm{~m}$ from the outcrop (Figure 2.2a). Back-rotation of the shear fabric into its pre-folding position yielded a ENE-WSW stretching direction for the shear zone with associated shear fabric implying top-WSW sense of shear, which means WSW-ward movement of the conglomerate-marble sequence with respect to the metapelites and the Pelagonian unit. The significance of this contact was proven by microstructural and petrological analysis of the sample from this outcrop (sample 3.3), which is described in the next section.

\subsubsection{Metamorphic conditions}

More than fifty thin sections were analyzed in an effort to characterize as precisely as possible micro-scale deformation processes and metamorphic mineral assemblages associated with the different formations and deformation phases. All outcrops of the main units on Skopelos display evidence of synmetamorphic, micro-scale processes such as dissolution creep, white mica (re)crystallization (Figures $2.5 \mathrm{~b}$ and c), calcite twinning (Figure $2.5 \mathrm{~h}$ ), quartz subgrain formation and grain boundary migration (Figure $2.5 \mathrm{~g}$ ), and chloritecalcite growth (Figure 2.5h). Chlorite growth is especially characteristic of the metabasaltic formation of the Glossa unit (Figure 2.5h) and is commonly accompanied by albite and epidote growth. Investigation of metamorphic mineral assemblages did not reveal significant differences in metamorphic grade between the different tectonic units of Skopelos, or between $D_{1}$ and $D_{2}$ deformation phases. Foliation $S_{1}$ is defined by larger white mica grains ( $\geq 250 \mu \mathrm{m}$ ) (Figures 2.6a and c) as compared with $\mathrm{S}_{2}$, which is commonly defined by mylonitic sericite fabric which overgrowing the pre-existing larger micas of the $S_{1}$ foliation (Figures 2.6b and c). The observed mineral assemblages and micro-scale deformation 
processes are consistent with metamorphism under greenschist-facies conditions both for $\mathrm{D}_{1}$ and $\mathrm{D}_{2}$ events.
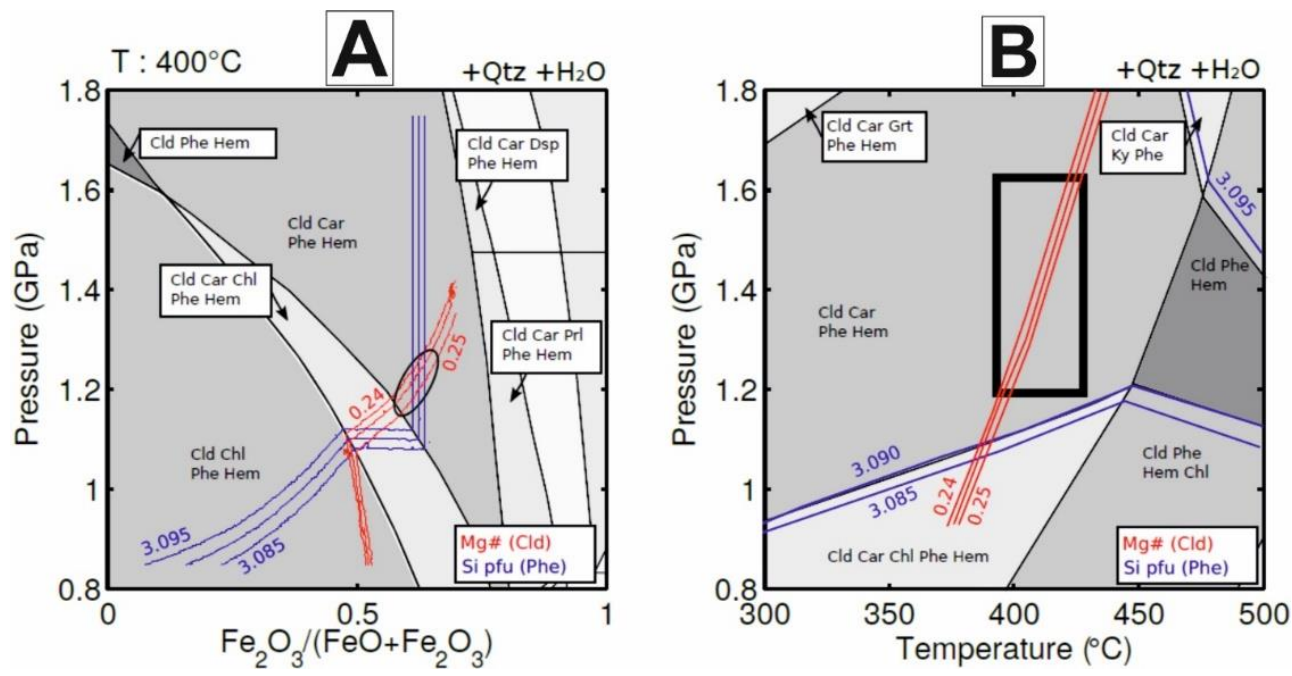

Figure 2.7. PX and PT sections for sample 3.3 (for sample location see Figure 2a, for thin section and outcrop images see Figure 5b-c and Figure 2.6a). Quartz $\left(\mathrm{SiO}_{2}\right)$ and water $\left(\mathrm{H}_{2} \mathrm{O}\right)$ were assumed in excess. (a) PX section calculated for $\mathrm{T}=400^{\circ} \mathrm{C}$. (b) Isochemical PT section.

An exception to the general greenschist facies conditions of $\mathrm{D}_{1}$ and $\mathrm{D}_{2}$ ductile fabrics was found in outcrop 3.3 (Figure 2.6a); the sample collected from the mylonitic metapelites exhibits an entirely different mineral content and associated PT conditions associated to $\mathrm{D}_{2}$ deformation as described in detail below. Representative mineral analyses from this outcrop are reported in the Appendix 1, whereas the whole-rock composition is listed in Appendix 2. In sample 3.3 (Figure 2.6b), chloritoid porphyroblasts (6vol\%) are set in a very fine-grained mylonitic fabric defined by phengite $(51 \%)+$ quartz $(38 \%)+$ hematite $(4 \%)$. Most of the chloritoid crystals are synkinematic (Figure $2.5 \mathrm{c}$ ) with respect to the shearing event (top-tothe-WSW) that produced the mylonitic foliation and often contain S-shaped quartz inclusion trails, although larger, pretectonic crystals have also been observed. Chloritoid crystals have grown at the expense of and contain inclusions of carpholite, indicating progressive crystallization typically under high-pressure/low-temperature conditions (Goffé et al., 1973; Pourteau et al., 2014; Vidal et al., 1992; Vidal et al., 1994), a rather common feature of blueschist-facies metapelites from various Tethyan localities (Agard et al., 2001; Goffé et al., 1988; Oberhänsli et al., 1998; Plunder et al., 2013; Trotet et al., 2006; Vidal and Theye, 1996). There is a continuum in chloritoid crystallization from the larger relictic grains to the smaller synfolial ones as attested to by their overlapping Mg\# values with the rims of the synfolial grains displaying the highest values (see Appendix 1), interpreted to have recorded the highest metamorphic grade (see Pourteau et al., 2014, their Figs. 7b, c \& d). To a first approximation, and according to the calculations of Pourteau et al. (2014) in the FMASH system, the range of observed chloritoid Mg\# values $(\sim 0.19-\sim 0.25)$ in the divariant chloritoid-carpholite field is consistent with temperatures between 350 and $450^{\circ} \mathrm{C}$ in the pressure range 1-2 GPa. 
Pressure and temperature conditions that prevailed during shearing of sample 3.3 were assessed using Gibbs free-energy minimization (Connolly, 2009; Connolly, 2005) and mineral and bulk-rock data from Appendix 1 and 2. The solution models used are: Ctd(HP) for chloritoid, Mica(CHA1) for white mica, Gt(GCT) for garnet, Chl(HP) for chlorite and Carp for carpholite (http://www.perplex.ethz.ch/).

The presence of hematite in the sample does not allow for a simple calculation of phase equilibria assuming all $\mathrm{Fe}$ as $\mathrm{Fe} 2+$. Even if measured $\mathrm{Fe} 3+$ values were available, we still cannot know how $\mathrm{Fe} 2+/ \mathrm{Fe} 3+$ could have possibly changed with time during metamorphism. To circumvent this problem, we introduced $\mathrm{Fe} 3+$ as an unknown variable. This, of course, increases the dimensionality of the problem (i.e. from 2 to 3 independent variables) and makes calculations more complicated. Our approach was to compute several 2D P-X sections assuming constant temperature $\left(350,375,400,425\right.$ and $\left.450^{\circ} \mathrm{C}\right)$, where $\mathrm{X}$ is the bulk-rock $\mathrm{Fe} 2 \mathrm{O} 3 /(\mathrm{Fe} 2 \mathrm{O} 3+\mathrm{FeO})$ ratio (in wt.\%) that becomes zero (0) when all Fe is present as $\mathrm{Fe} 2+$ and one (1) when all $\mathrm{Fe}$ is present as $\mathrm{Fe} 3+$. The presence of hematite and $\mathrm{Fe} 2+$-bearing minerals in 3.3 suggests that $\mathrm{X}$ lies between 0 and 1 .

We simplified the pelitic composition by ignoring the minute amounts of $\mathrm{Na}, \mathrm{Ca}$ and $\mathrm{Ti}$ and assumed that the system is saturated in $\mathrm{H} 2 \mathrm{O}$ (water) and $\mathrm{SiO} 2$ (quartz) (i.e. $\mathrm{K} 2 \mathrm{O}-\mathrm{FeO}$ $\mathrm{Fe} 2 \mathrm{O} 3-\mathrm{MgO}-\mathrm{Al} 2 \mathrm{O} 3-\mathrm{SiO} 2-\mathrm{H} 2 \mathrm{O}$ system). The calculated misfit between modelled and measured mineral compositions (see Hunziker et al., 2017, their Equation 1) is minimized for temperatures between 400 and $425^{\circ} \mathrm{C}$. For an $\mathrm{X}$ value of $\sim 0.62$, the crossing of the Si-inPhe (atoms per formula unit or apfu; see Appendix 1) and Mg\#-in-Cld isopleths at these temperatures occurs at $\mathrm{P} \sim 1.2$ and $1.6 \mathrm{GPa}$ respectively. Figure $2.7 \mathrm{a}$ is a $\mathrm{P}-\mathrm{X}$ section for $\mathrm{T}=400^{\circ} \mathrm{C}$. The corresponding $\mathrm{P}-\mathrm{T}$ section for that particular composition is depicted in Figure 2.7b. Considering the uncertainties due to ferric iron, the compositional isopleths of Mg\#-in-chloritoid, Si-in-phengite and the thermodynamic stability of the assemblage (CarCld-Qz-Phe-Hem; mineral abbreviations after Whitney and Evans, 2010) suggest that metamorphic recrystallization should have taken place at $\mathrm{T}=400-425 \pm 25^{\circ} \mathrm{C}$ and $\mathrm{P}=1.2-1.6$ $\pm 0.2 \mathrm{GPa}$. This is in agreement with but refines much more rigorously the $\mathrm{P}-\mathrm{T}$ bracket inferred earlier, based on thermodynamic modelling of carpholite-chloritoid equilibria alone (Pourteau et al., 2014). Our figures represent a robust estimate of the $\mathrm{P}-\mathrm{T}$ conditions under which the observed mylonitic foliation formed in sample 3.3. The calculated thermodynamic pressure here is essentially equal to the mean stress but could deviate from lithostatic (Moulas et al., 2013; Moulas et al., 2018).

\subsection{4 ${ }^{40} \mathrm{Ar} /{ }^{39} \mathrm{Ar}$ dating}

\subsubsection{Single grain fusion experiments}

The results of single grain fusion experiments are presented on Figure 2.8. The plots show largely heterogeneous distributions of ages which could theoretically indicate either that: 1) the timing of closure was heterogeneous (meaning multiple geological events); 2) inherited argon is unequally removed from the crystals; 3 ) there is variable amount of excess argon. In our case two main age groups can be distinguished based on the ${ }^{40} \mathrm{Ar} /{ }^{39} \mathrm{Ar}$ dating: a Paleozoic (>250Ma) group, and an Early Cretaceous, 105-135Ma group. Especially samples 8.1 and 12.4 show clear peaks of Early Cretaceous ages showing that most of the white micas in these samples date an event in the Early Cretaceous. The presence of Paleozoic single grain 
fusion ages in the pre-Early Cretaceous metasedimentary formations (Pelagonian, Glossa, and the basal formation of the Palouki units) implies that temperature reached during the Early Cretaceous event was not high enough $\left(<500^{\circ} \mathrm{C}\right)$ to reset the $\mathrm{Ar}$-system of all the white micas by thermally activated volume diffusion, allowing in some grains the Variscan protolith ages to be preserved. Early Cretaceous ages thus most likely represent deformationdriven recrystallization and cannot be interpreted as cooling ages (Warren et al., 2012a).
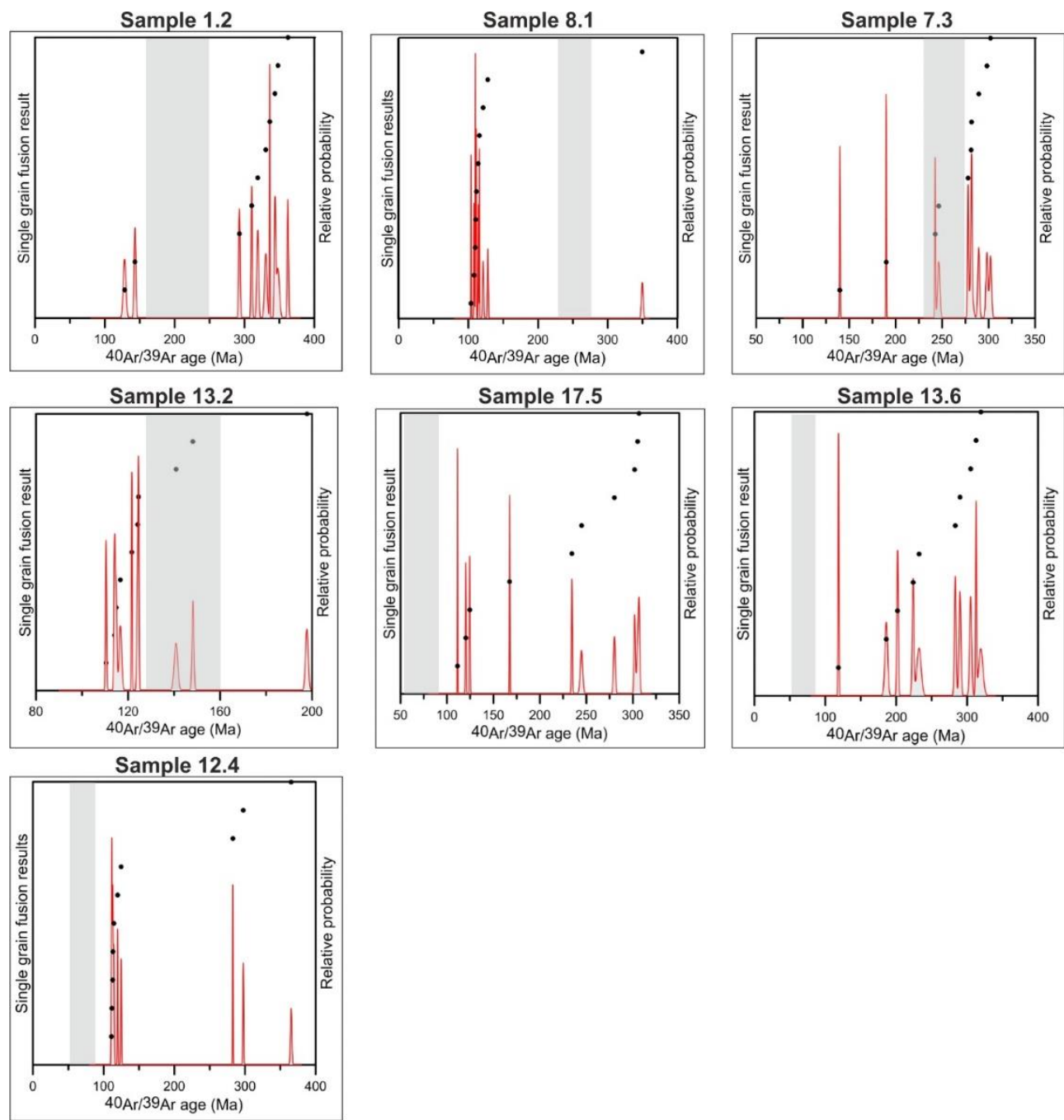

Figure 2.8. Diagrams of ${ }^{40} \mathrm{Ar} /{ }^{39} \mathrm{Ar}$ single grain fusion dating experiments on larger $(\geq 200 \mu \mathrm{m})$ white mica crystals. The diagrams show the age distribution of single mica crystals (black dots) and the relative probability of the results (red line). The relative probability is a function of the absolute age and the corresponding $\sigma 1$ error of a single mica grain. If individual error is small with respect to the bin size one gets a spikier representation of the peaks. Grey stripes indicate the stratigraphic extent of the units of which the samples are derived from. For sample locations see Figure 2.2a. For thin section images of samples 8.1 and 12.4 see Figures 2.6a and 2.6d, respectively. 
This means that the Early Cretaceous grains provide direct constraints for the timing of a tectono-metamorphic event in the pre-Early Cretaceous formations. On the other hand, Paleozoic ages are likely to represent the cooling of the Variscan basement rocks or alternatively Variscan deformation events. The fact that the signal of detrital, Variscan grains and newly formed Early Cretaceous grains can be separated shows the strength of the single grain fusion approach as long as the temperature of metamorphism does not exceed $500{ }^{\circ} \mathrm{C}$ (for more details about the single grain fusion approach see Uunk et al., 2018). For example, in case of sample 8.1 which comes from the metaclastic series of the Pelagonian unit, the majority of the white micas define the $S_{1}$ foliation of the rock which formed during a metamorphic event (Figure 2.5a). However, the sample also contains larger clasts with detrital white micas (Figure 2.5a). Looking at the age distribution of sample 8.1 on Figure 2.8 , the result shows a very good agreement with the observations in the thin section: a clear Early Cretaceous peak (9 grains with similar ages) defining the metamorphic event, but also one detrital grain which shows Variscan origin and proves that resetting in the Early Cretaceous was not achieved by thermal diffusion, but by deformation-induced crystallization.

Grains with ages between the Early Cretaceous and the Paleozoic - that are difficult to explain from a geological point of view - might be the consequence of unequally removed inherited argon leading to mixed ages intermediate between the two recorded events (Figure 2.8). 

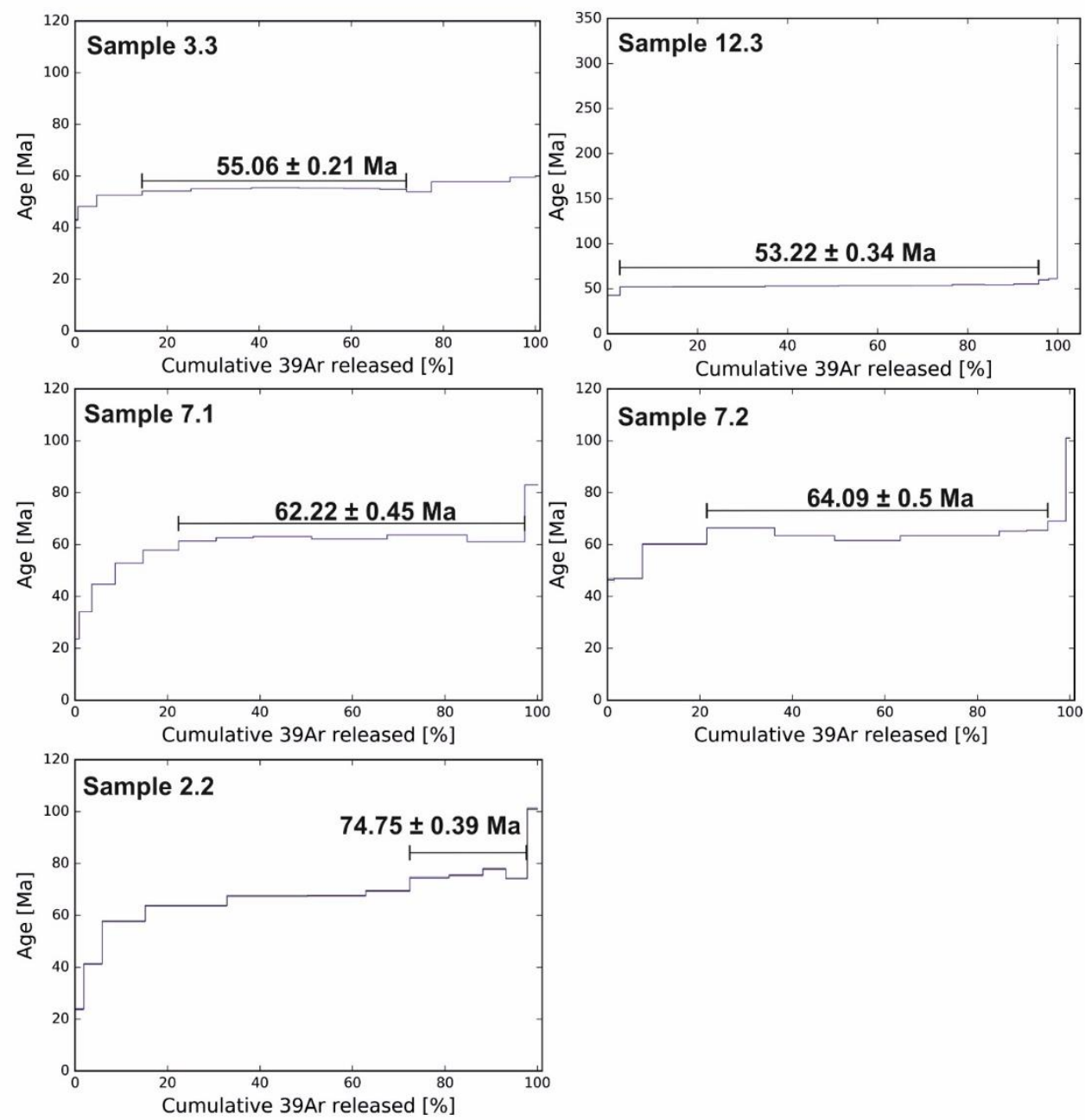

Figure 2.9. Diagrams of ${ }^{40} \mathrm{Ar} /{ }^{39} \mathrm{Ar}$ step heating fabric dating experiments on fine grained white micas (sericite). The horizontal axes show the cumulative ${ }^{39} \mathrm{Ar}$ released during the step heating, while vertical axes show the age of Ar-loss. For sample locations see Figure 2.2a. For thin section images of samples 3.3, 7.2, and 7.1 see Figures 2.5b-c, d, and e, respectively. Note that the $\sigma 1$ error [Ma] of each heating step is plotted with blue lines which tend to be very close to the result function (black line).

\subsubsection{Step heating experiments: dating $S_{2}$ fabrics}

The results of step heating experiments on the $S_{2}$ sericite foliations are presented on Figure 2.9. Age spectra show a dominance of 53-75 Ma, documenting the $\mathrm{S}_{2}$ fabric-forming event in the rocks of Skopelos. The samples from the Mesoautochtonous unit (samples 3.3 and 12.3) show younger ages than the samples from the Glossa and Pelagonian units (samples $7.1,7.2,2.2$ ). This might be due to earlier fabric formation in those samples, or alternatively to the presence of minor amount of Early Cretaceous mica fragments in the ground mass of samples 7.1, 7.2, and 2.2. The determination of the ages based on the spectra seems robust in 
all samples except for sample 2.2 where the more complicated age spectra would also allow to define a younger age of ca. 65Ma. However, based on the number of steps (4 versus 3 ) we prefer to accept the $\sim 75 \mathrm{Ma}$ age for sample 2.2 (Figure 2.9). Staircase-shaped age spectra of samples 7.1 and 2.2 imply that a younger (probably $\sim 25 \mathrm{Ma}$ ) thermal overprinting event affected these samples. Since this event is not present in all samples, the regional significance of this overprint is not clear.

\subsection{Interpretation of results}

\subsubsection{Late Jurassic-Early Cretaceous evolution of Skopelos}

$D_{1}$ deformation phase on Skopelos is defined by the remnants of a first foliation $\left(S_{1}\right.$ on Figure 2.5a, d, and e), NW-SE trending stretching lineations, and related shear sense indicators showing top-NW and top-SE sense of shear (Figure 2.3a and b). A distinct group of first-generation, cylindrical isoclinal folds $\left(\mathrm{F}_{1}\right)$ have NE-SW trending fold axes (Figure 2.3c), which fits to the NW-SE shearing suggested by the $\mathrm{L}_{1}$ stretching lineations and associated shear sense indicators. $\mathrm{D}_{1}$ structures are limited to the Pelagonian, Glossa, and the oldest formation of the Palouki units.

Single grain fusion ${ }^{40} \mathrm{Ar} /{ }^{39} \mathrm{Ar}$ dating of white micas allows us to define a clear fabricforming event in the Early Cretaceous ( 105-135 Ma) (Figure 2.8) that by multi-grain dating would have been partly obscured by admixing of a Variscan component in the sample material. In case of the Pelagonian, Glossa, and in the oldest formation of the Palouki units, the single grain fusion approach allows for separating detrital, Variscan micas from grains defining the $S_{1}$ foliation (Figure 2.5a). Since the temperature during $\mathrm{D}_{1}$ deformation was not high enough to reset the detrital grains by thermal diffusion, we conclude that the Early Cretaceous ages are achieved by deformation-induced crystallization and treat them as direct time constraints for the formation of the $S_{1}$ foliation and thus the timing of $D_{1}$ deformation phase. The lack of any remnants of a higher-temperature mineral association and the presence of non-reset detrital white micas in the relevant formations suggest that metamorphic conditions during $\mathrm{D}_{1}$ phase did not exceed greenschist facies.

The Pelagonian unit of Skopelos was deposited on the passive margin of the Pelagonian continental basement facing the Neotethys/Vardar ocean (Figure 2.11a). In our interpretation, the Glossa unit represents the deep water-facies equivalent of the Pelagonian unit, and was deposited coevally on the distal Pelagonian margin and/or on the ocean-continent transition zone (Figure 2.11a). A similar reconstruction has already been proposed linking the Eohellenic nappe (Jacobshagen et al., 1978) and as part of that the Glossa unit (Matarangas, 1992) with the Vardar ocean.

The origin of the Palouki unit, the stratigraphic range of the basal formation of the unit, and the contact between the basal and the upper formations have not been clarified so far (Matarangas, 1992). Our ${ }^{40} \mathrm{Ar} /{ }^{39} \mathrm{Ar}$ white mica single grain fusion ages from the basal formation of the Palouki unit show a roughly 110-125 Ma white mica population in the formation. The fossils found in the basal Palouki formation provide a Late Jurassic-Early Cretaceous possible range of deposition (Matarangas, 1992). Our ${ }^{40} \mathrm{Ar} /{ }^{39} \mathrm{Ar}$ ages imply that the formation was buried and metamorphosed around 110-125 Ma (sample 13.2 on Figure 
2.8), which brackets the possible depositional range of the basal Palouki formation between 130-160 Ma. In our view the basal formation of the Palouki unit was most likely deposited on top of the Eohellenic units (in the sense of Jacobshagen et al., 1978), prior to Early Cretaceous metamorphism of the Pelagonian margin (Lips et al., 1998; Most, 2003; Schermer et al., 1990; Walcott, 1998), in front of the advancing ophiolitic thrust sheet(s). This idea is supported by deep water facies characteristics of the sedimentary succession (Matarangas, 1992) and blocks of serpentinites and mafic volcanics in the formation. In this sense the basal Palouki formation is similar to the sub-ophiolitic mélange mapped on Evia (e.g. Danelian and Robertson, 2001), in the northern part of the Pelagonian zone (e.g. Sharp and Robertson, 2006), or in the Internal Dinarides (e.g. Gawlick et al., 2009; Schmid et al., 2008).

Following the deposition of the lowermost Palouki formation, the Pelagonian margin was overthrust by the Neotethyan ophiolites and consequently buried to greenschist facies conditions. The Glossa unit on Skopelos was most likely emplaced on top of the Pelagonian unit during the Early Cretaceous $\mathrm{D}_{1}$ phase. This scenario is compatible with the idea of passive margin inversion during obduction (Figure 2.11b) and is also supported by commonly found SE-and NW-verging, isoclinal $F_{1}$ folds as well as NW-SE trending $\mathrm{L}_{1}$ stretching lineations in the proximity of the contact, implying a NW-SE trend of movement (Figure 2.3).

As it is suggested by our single grain fusion ${ }^{40} \mathrm{Ar} /{ }^{39} \mathrm{Ar}$ ages (Figure 2.8), $\mathrm{S}_{1}$ fabric formation in the Pelagonian, Glossa, and the lowermost formation of the Palouki units ceased 110-105 Ma suggesting the exhumation of these units above the brittle-ductile transition zone. The formations were subsequently transgressed by the Mesoautochtonous unit and the upper formations of the Palouki unit from the latest Albian-Early Cenomanian ( 100-95 Ma) (Matarangas, 1992), implying surface exposure of the older units. The ${ }^{40} \mathrm{Ar} /{ }^{\beta 9} \mathrm{Ar}$ ages and the stratigraphical constraints together constrain the timing of $D_{1}$ exhumation for the late Early Cretaceous.

\subsubsection{Late Cretaceous-Paleogene evolution of Skopelos}

${ }^{40} \mathrm{Ar} /{ }^{39} \mathrm{Ar}$ sericite $\mathrm{S}_{2}$ fabric ages of present study (Figure 2.9) define a latest Cretaceous - earliest Eocene period of ductile fabric formation ( $S_{2}$ main foliation) in all units of Skopelos. This foliation is pervasive on the whole island and its formation is associated with NE-SW tectonic transport evidenced by stretching lineations and kinematic indicators (Figure 2.3b). Dating of fabrics related to $\mathrm{D}_{2}$ deformation allows us to assign $\mathrm{D}_{2}$ structures with a latest Cretaceous - earliest Eocene period. Without having a clear distinction between early and late $\mathrm{D}_{2}$ deformations (top-SW vs top-NE shearing) in terms of metamorphic grade and mineral associations, it is difficult to assign the $\mathrm{S}_{2}$ fabric forming to either top-SW or top-NE shearing. The mylonitic fabric of sample 3.3. (Figure 2.5b and c) however shows a clear top-WSW sense of shear and a well-developed $\mathrm{S}_{2}$ foliation that is dated to be $\sim 55 \mathrm{Myr}$ old. This and the observations that top-NE shearing usually affects an already existing $\mathrm{S}_{2}$ foliation suggest that the $\mathrm{D}_{2}$ fabric-forming event was predominantly associated with the topSW shearing.

The metamorphic grade of $\mathrm{D}_{2}$ phase is constrained by microscale deformation mechanisms and metamorphic mineral assemblages which imply greenschist facies conditions for the rocks of Skopelos except for one blueschist facies shear zone (Figures 2.6a 
and 2.7) between the Pelagonian and Mesoautochtonous units. Considering the generally low metamorphic grade of the formations, we suggest that the rocks of Skopelos were not subducted to great depth together with the Pelagonian basement (e.g. Brun et al., 2016) during $\mathrm{D}_{2}$ burial, but they were rather incorporated into an accretionary wedge between Pelagonia and Eurasia.

The top-SW distributed shearing (Figure 2.3b), thrusting of the Palouki unit on top of the Mesoautochtonous unit, and the top-WSW shear zone between the Pelagonian and Measoautochtonous units (Figure 2.11d) are correlated with the tectonic burial (thrusting) within the accretionary wedge during the latest Cretaceous-earliest Eocene.

The top-WSW blueschist facies shear zone at the base of the Mesoautochtonous unit consists of mylonitic metapelites that carries a foliation with a $55 \mathrm{Ma}^{40} \mathrm{Ar} /{ }^{39} \mathrm{Ar} \mathrm{S}$ fabric age (Figures 2.5a, 2.7, and 2.8). The same high-pressure metapelites at the base of the Mesoautochtonous unit were described by Mposkos and Liati (1991a) at the southwestern shore of the island, implying that the high-pressure shear zone is not only locally present between the Pelagonian and the Mesoautochtonous units. Since the high-pressure shear zone separates the Pelagonian and the Mesoautochtonous units, which are observed to have an erosional contact in most outcrops (Matarangas, 1992), we propose that parts of the erosional unconformity were activated during top-SW tectonic burial phase as a shear zone (Figure 2.11d). This view contradicts the previous interpretation which reckoned with an erosional contact between the Mesoautochtonous and the Pelagonian units on the whole island (Matarangas, 1992).

The contact between the Pelagonian and the Glossa units has been described as a thrust based on the observation that the Glossa unit is structurally lying on top of the Pelagonian (Matarangas, 1992). According to our observations, the latest movement along this contact was top-NE shearing with normal kinematics (Figure 2.6c). However, we suggest that the Glossa unit was emplaced on top of the Pelagonian by a $\mathrm{D}_{1}$ thrust or a reverse-sense shear zone preceding the activity of the $\mathrm{D}_{2}$ top-NE normal-sense shear zone (Figure $2.11 \mathrm{~b}$ ). The $\mathrm{D}_{2}$ shear zone thus reactivated or alternatively cut the Early Cretaceous $\left(D_{1}\right)$ nappe contact between the two units (Figures 2.11d and e).

The dominant top-NE shearing (Figure $2.3 \mathrm{~b}$ ) overprints older $\mathrm{D}_{1}$ or early- $\mathrm{D}_{2}$ ductile structures (Figures $2.4 \mathrm{~b}, \mathrm{f}, \mathrm{g}$ ) and occurred under decreasing temperatures as documented by the gradual change of ductile shearing to normal faulting (Figure 2.6c), within the same kinematic frame. We thus correlate the top-NE shearing on Skopelos with the extensional exhumation of the accretionary wedge above the brittle-ductile transition zone. According to our observations, this first stage of exhumation was largely accommodated by distributed top-NE shearing (Figure 2.3b), and by the formation of a few top-NE shear zones which localized along pre-existing rheological contrasts, and dip sub-parallel to the main foliation $\left(\mathrm{S}_{2}\right)$ (Figures 2.2, 2.6b and c, and 2.11e and f). These shear zones may have a minor to medium (few 100 or $1000 \mathrm{~m}$ ) of displacement (Figure 2.11f) and consequently do not cut out major parts of the stratigraphy. We suggest that the distributed and localized top-NE shearing together played an important role in the exhumation of Skopelos. 


\subsection{Implications for the Early Cretaceous tectonics of the Pelagonian margin}

\subsubsection{Correlation of Early Cretaceous tectonic events in the Pelagonian zone}

Early Cretaceous tectono-metamorphic events ( $D_{1}$ in present work) have been reported from many locations along the Pelagonian zone (Figure 2.10a) and from its continuation into the Dinarides (Internal Dinaric thrust sheets such as the Drina-Ivanjica and the JadarKopaonik (Schmid et al., 2008). Single grain ${ }^{40} \mathrm{Ar} /{ }^{39} \mathrm{Ar}$ laserprobe dating combined with petrological investigations showed the existence of a distinct blueschist to greenschist facies tectonic event in the region of the Pelion peninsula and the Ossa tectonic window (Lips et al., 1998; Lips et al., 1999) (Figure 2.10A), while $\mathrm{Rb} / \mathrm{Sr}$ and multigrain ${ }^{40} \mathrm{Ar} /{ }^{39} \mathrm{Ar}$ dating provided younger mixed ages (85-135 Ma) in the blueschist to greenschist facies rocks of the Olympos tectonic window (Schermer et al., 1990). Early Cretaceous metamorphism in the northeastern part of the Pelagonian zone was identified by K/Ar dating (Most, 2003) (Figure 2.10a). Furthermore, remnants of high-temperature metamorphism during the Early

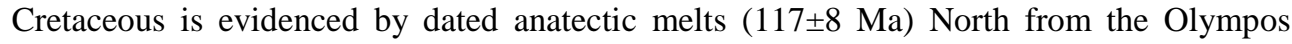
window (Schenker et al., 2014). Walcott (1998) determined a large population of greenschist to amphibolite facies, NW-SE and weak E-W trending stretching lineations from the Thessaly-Pelion region and assigned top-SE and top-E tectonic transport to the Early Cretaceous. NW-SE and E-W trending stretching lineations have been determined in the Pelagonian unit in NW-Thessaly (Kilias et al., 1990; Sfeikos, 1992), and in the northern part of the Pelagonian zone (Kilias et al., 2010; Most, 2003; Sharp, 1994; Sharp and Robertson, 2006) without identifying a preferential sense of shear (Figure 2.10a). The above-mentioned ductile fabrics imply NW-SE or E-W tectonic transport and have been assigned to the Late Jurassic or Early Cretaceous ophiolite emplacement and subsequent deformation of the Pelagonian zone or alternatively to an early collision between Pelagonia and Rhodopia (Schenker et al., 2014). 


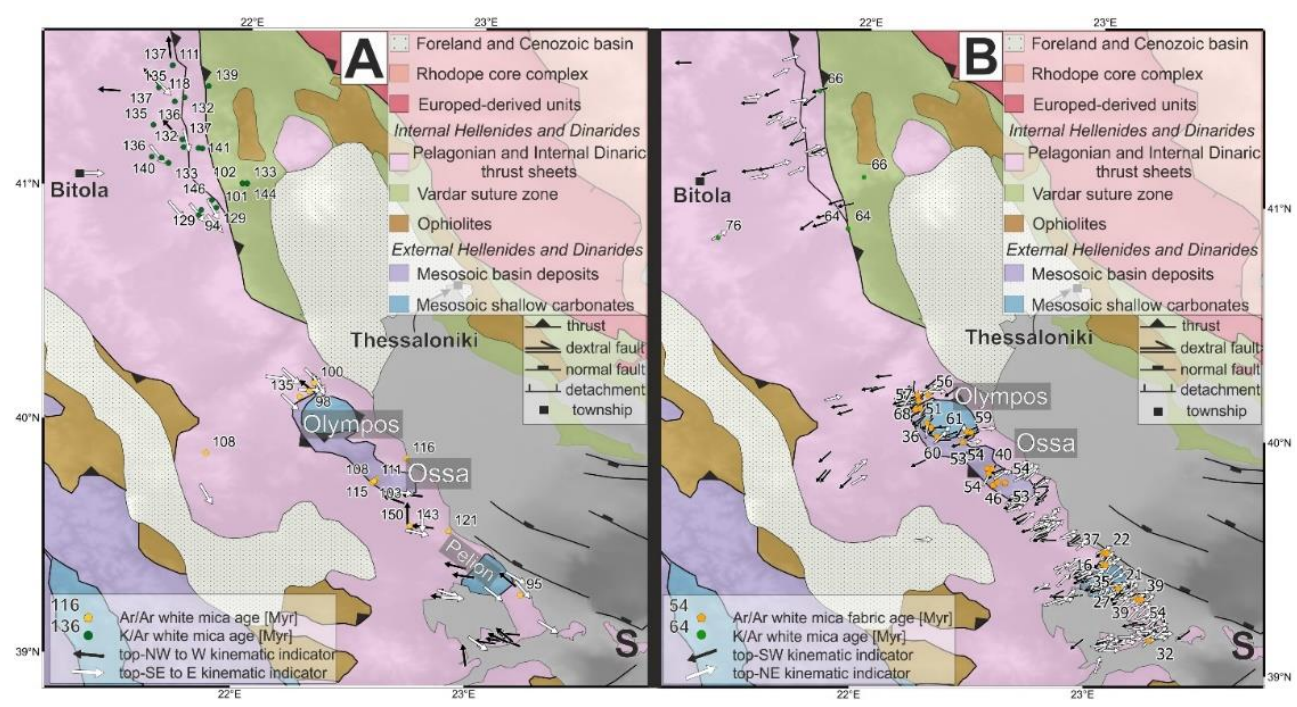

Figure 2.10. Correlation of deformation phases in the Pelagonian zone. The basis for correlation are geochronological and kinematic datasets compiled from published data (Gerogiannis and Xypolias, 2017; Kilias et al., 2010; Lips et al., 1998; Lips et al., 1999; Most, 2003; Schermer et al., 1990; Walcott, 1998) which are comparable to our results from Skopelos. S=Skopelos. (a) Correlation of $\mathrm{D}_{1}$ phase: Early Cretaceous resetting of Ar-Ar and $\mathrm{K}-\mathrm{Ar}$ systems coupled to observed top-NW or top-SE directed tectonic transport indicated by stretching lineations and associated kinematic indicators. Note that Early Cretaceous tectono-metamorphic events have also been reported from the Europe-derived units (e.g. Kydonakis et al., 2016), however we focus exclusively on the Pelagonian zone. (b) Correlation of $\mathrm{D}_{2}$ phase: latest Cretaceous-Paleogene $\mathrm{Ar} / \mathrm{Ar}$ white mica fabric ages and K/Ar ages coupled to observed top-SW and top-NE tectonic transport.

Further to the NW, the Pelagonian zone continues in the Internal Dinarides. Based on stratigraphy and structural position, the Pelagonian zone of the Hellenides can clearly be correlated with the Internal Adria-derived thrust sheets structurally underlying the obducted ophiolites of the Dinarides (e.g. Schmid et al., 2008). Early Cretaceous metamorphism in the Internal Dinarides is constrained by $\mathrm{K} / \mathrm{Ar}$ thermochronology (Milovanović, 1984; Milovanovic et al., 1995; Porkoláb et al., 2018; Tomljenović et al., 2008), and Early-to Late Cretaceous metamorphism by ${ }^{40} \mathrm{Ar} /{ }^{39} \mathrm{Ar}$ thermochronology (Schefer, 2012). Similarly to the Pelagonian zone in the Hellenides, WNW-ESE stretching lineations and top-WNW sense of shear has been reported from the sub-ophiolitic units marking the tectonic transport direction of the ophiolite thrust sheet(s) (Carosi et al., 1996; Schefer, 2012; Schmid et al., 2008). Our correlation shows, that Early Cretaceous tectono-metamorphic events along the Pelagonian zone in Greece and in the Internal Dinarides have similar timing and similar directions of tectonic transport following the emplacement of Neotethyan ophiolites. 


\subsubsection{Early Cretaceous underthrusting of the Pelagonian margin}

Cessation of deposition on the Pelagonian margin is linked with the obduction of Neotethyan ophiolites (e.g. Danelian and Robertson, 2001; Scherreiks, 2000). Subduction initiated in an intra-oceanic setting (e.g. Barth et al., 2008; Bortolotti et al., 2013; Maffione et al., 2015) in Middle-Late Jurassic times (Dimo-Lahitte et al., 2001; Spray et al., 1984) (Figure 2.11a). As shown on Figure 2.10a and discussed in section 6.1, Early Cretaceous deformation and metamorphism can be correlated from Skopelos, through the Pelagonian zone, up to the Internal Dinarides. Consequently, underthrusting of the distal Pelagonian/Adriatic units below the obducting Neotethyan units was a regional-scale process. The thermo-mechanical feasibility of such a system has been tested numerically with a series of experiments, suggesting that ophiolite obduction is a process that remains stable in a broad physical parameter range (Duretz et al., 2016a). Strong continental basement rheology plays a key role in obduction while switch from compression to extension seems to be important for the subsequent exhumation of metamorphic rocks following underthrusting (Duretz et al., 2016a). However, the effect of surface processes on the conditions of exhumation has not been investigated yet, and the general lack of identified major Early Cretaceous exhuming structures (shear zones or normal faults) in the region might imply that erosion played a major role in this process. Exhumation following a short-lived underthrusting of the continental margin is consistent with the presence of regional Late Jurassic - Early Cretaceous unconformities truncating both oceanic and metamorphosed continental units (Jacobshagen and Wallbrecher, 1984; Robertson, 1991; Sharp, 1994) in the Pelagonian zone (Figure 2.11c). The trend of tectonic transport during the Late Jurassic Early Cretaceous along the Pelagonian zone is consistently between NW-SE and E-W (Figure 2.10a) but kinematic indicators are observed to be double-vergent (both top-NW to $\mathrm{W}$ and top SE to E) on Skopelos (Figure 2.3) as well as and on a larger scale (Figure 2.10a). According to plate tectonic reconstructions, the Pelagonian/Adriatic continental margin was located to the W (e.g. Maffione and van Hinsbergen, 2018; Robertson et al., 1996) or SW (e.g. Stampfli and Borel, 2002) from the Neotethys/Vardar oceanic domain. Considering that the clockwise rotation in the Pelagonian zone has been substantial (roughly $30-50^{\circ}$ ) since Eocene times (van Hinsbergen and Schmid, 2012; van Hinsbergen et al., 2008 and references therein), we can restore the top-NW to $\mathrm{W}$ kinematic indicators to roughly top-W-SW. Therefore, in our view the Early Cretaceous top NW-W kinematic indicators (now in present day coordinates) in the Pelagonian zone are likely to represent the record of underthrusting below the Neotethyan/Vardar ophiolites. This view is also supported by the top-W structural polarity of obduction-related deformation in Northeastern-Albania (Tremblay et al., 2015), in Western-Serbia (Porkoláb et al., 2019a), and top-WNW shear sense indicators in the metamorphic sole and sub-ophiolitic mélange of the Internal Dinarides (Carosi et al., 1996; Schefer, 2012; Schmid et al., 2008). 

120-130 Ma: $D_{1}$ phase W-NW

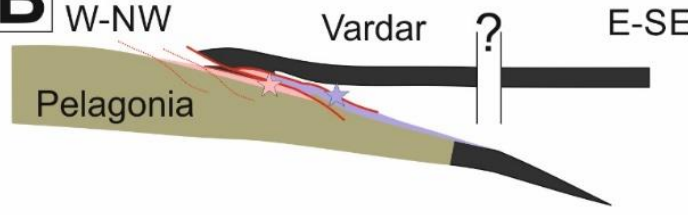

70-80 Ma

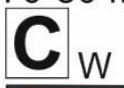

Deposition:

Pelagonia Mesoautochtonous and Palouki units

Palouki unit

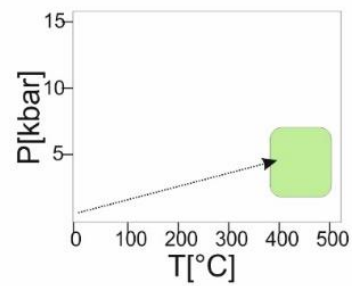

Mesoautochtonous unit

\section{Vardar'suture}

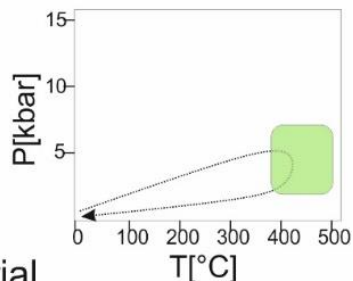

Glossa/Eohellenic unit

Pelagonian unit

Continental crust (basement)

- Oceanic crust

Accretionary wedge undifferentiated

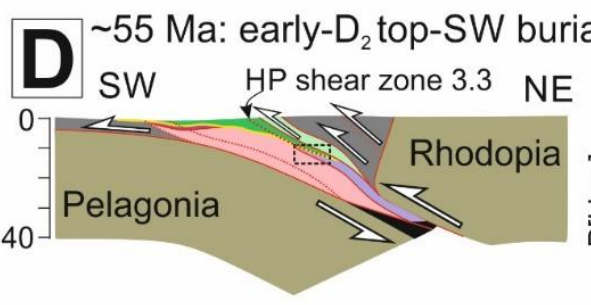
$\mathrm{T}\left[{ }^{\circ} \mathrm{C}\right]$ Approximate location of Skopelos

Normal-sense

shear zone

Reverse-sense shear zone Erosional unconformity
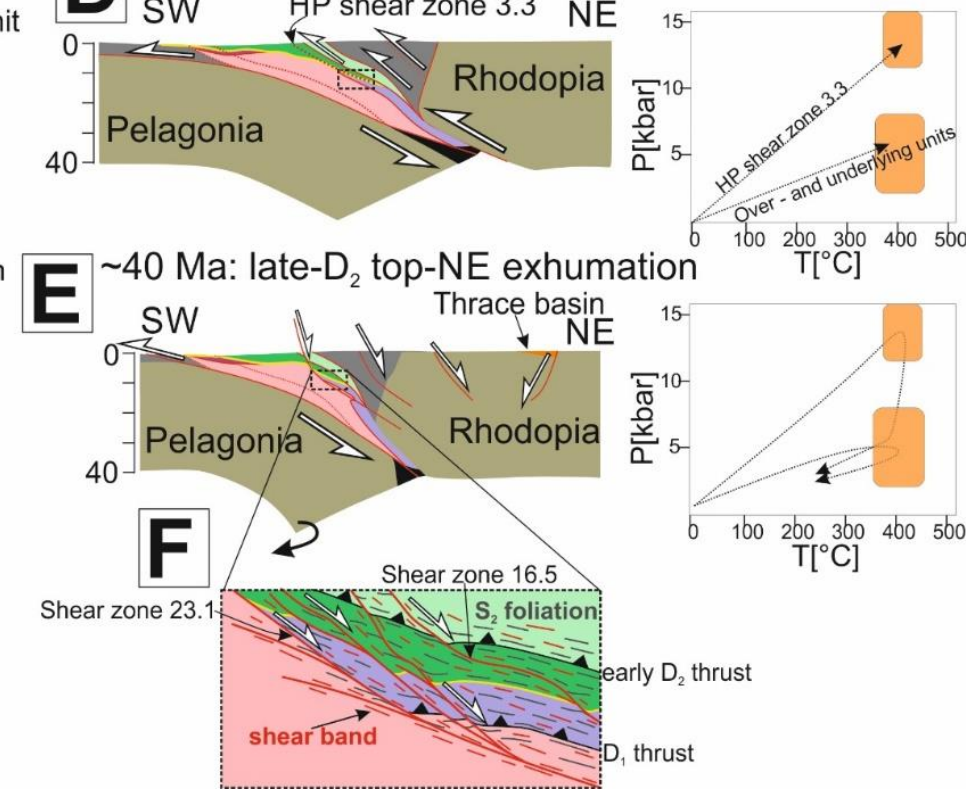

$\mathrm{T}\left[{ }^{\circ} \mathrm{C}\right]$

Figure 2.11. Simplified five-step evolutionary model of the Pelagonian margin and the tectonic units of Skopelos between $\sim 170$ and $\sim 40$ Ma. For steps (b) to (e), plots show the estimated pressure-temperature evolution of Skopelos. (a) Intra-oceanic subduction initiation in the proximity of the Pelagonian passive margin. (b) Underthrusting of the Pelagonian margin below the Vardar ophiolites driving metamorphism and deformation ( $\mathrm{D}_{1}$ on Skopelos) of the passive margin sediments. The Glossa unit is emplaced on top of the Pelagonian unit. (c) Uplift and erosion of the Pelagonian margin and the obducted ophiolites. Deposition of Late Cretaceous sediments (Mesoautochtonous and Palouki units on Skopelos) on top of the metamorphic rocks. 
(d) Development of an accretionary wedge in the collision zone between Pelagonia and Rhodopia. All the units of Skopelos were incorporated in the wedge after being carried down by the subducting Pelagonian basement. Top-SW tectonic transport and greenschist to blueschist facies metamorphism characterized the burial of the units. (e) Initial exhumation of the accretionary wedge by top-NE extensional shearing following the initiation of slab roll-back. (f) Magnification of the approximate location of Skopelos on Figure 2.11e showing the detailed interpretation of the observed pervasive top-NE shearing. The shear zones run sub-parallel to the main foliation $\left(\mathrm{S}_{2}\right)$ causing only minor modifications in the nappe structure but triggering the development of distributed top-NE shear in all the units of Skopelos.

On the other hand, the interpretation of the commonly found opposite top-SE to E kinematic indicators within the Pelagonian zone (Figure 2.10a) remain enigmatic. A sound solution would be to assign the top-SE to E shearing to the extensional exhumation of the continental margin following the obduction of the ophiolites, however no convincing structural analysis has been presented so far which would confirm the extensional nature of these structures or the relative timing with respect to the top-NW to $\mathrm{W}$ shearing. An alternative explanation could be a double-vergent thrusting scenario producing both top-NW to $\mathrm{W}$ and top-SE to $\mathrm{E}$ shear zones related to the inversion of the passive margin during/following obduction. Both ideas would need to be confirmed by a robust structural analysis from multiple locations along the Pelagonian zone.

\subsection{Implications for the Late Cretaceous - Paleogene tectonics of the Pelagonian zone}

\subsubsection{Correlation of Late Cretaceous - Paleogene tectonic burial in the Aegean region}

Deposition of Albian-Turonian transgressive conglomerates, carbonates, and on top Turonian - Paleogene flysch marks Late Cretaceous-Paleogene transgression and the evolution of a foredeep basin between Pelagonia and Eurasia/Rhodopia (Jacobshagen and Wallbrecher, 1984; Matarangas, 1992). Latest Cretaceous - Paleogene metamorphism and top-SW thrusting directions have been reported from all over the Aegean region (Figure 2.10b) and also from the Dinarides (e.g. Schefer, 2012). Recent tectonic models of the Aegean region suggest NE-ward subduction of the Pelagonian continental lithosphere below Eurasia/Rhodopia following the final closure of the Vardar ocean (e.g. Brun et al., 2016; Jolivet and Brun, 2010; Ricou et al., 1998). NE-ward subduction led to the formation of topSW shear fabric in the lower plate units such as Pelagonia associated with prograde metamorphism (Figure 2.10b) (Brun et al., 2016 and references therein; Philippon et al., 2011). Lower plate units which are now found on the surface have experienced metamorphism in various degrees. Blueschist to greenschist facies rocks with Late Cretaceous - Early Eocene mylonitic fabrics are found in the tectonic windows of the Olympos and Ossa regions where a more external thrust sheet of the Hellenides-nappe-stack crop out (Lips et al., 1998; Schermer et al., 1990) (Figure 2.1). Rocks from greenschist to blueschist facies are also found in the Pelion peninsula showing Paleogene-Miocene fabric ages (Gerogiannis and Xypolias, 2017; Lips et al., 1999; Walcott, 1998). Blueschist to 
eclogite facies rocks with Paleogene fabrics are found in the region of the Cyclades (e.g. Jolivet and Brun, 2010; Jolivet et al., 2010; Laurent et al., 2017; Lister and Forster, 2016; Wijbrans et al., 1990). Rb/Sr dating from the North Pelagonian zone has also indicated Paleogene metamorphism (Koroneos et al., 1993). All these results have been assigned to the Paleogene suturing of Adria-and Europe-derived units and the formation of the SW-verging Aegean nappe stack. Paleogene suturing of Adria-derived units and Eurasia is also welldocumented in the Internal Dinarides: top-SSW to W nappe stacking and related metamorphism has been dated and reported from the Kopaonik thrust sheet (Schefer, 2012) and the Sava Zone (Ustaszewski et al., 2010). Based on the Paleogene foredeep deposits of Skopelos (Mesoautchtonous and Palouki flysch formations) and the similarities in timing and kinematics of ductile deformation shown by Figure $2.10 \mathrm{~b}$, we correlate the top-SW $\mathrm{D}_{2}$ structures of Skopelos and related $\mathrm{S}_{2}$ fabric formation defined by the present study with the final closure of the Neotethys ocean that led to the second episode of burial and subsequent exhumation of the Pelagonian zone (Figure 2.11d).

\subsubsection{Paleogene accretionary wedge evolution on Skopelos}

The metamorphic grade during $\mathrm{D}_{2}$ phase was greenschist facies for all units of Skopelos, except for one blueschist facies shear zone (Figures 2.5a and 2.7) located at the base of the Mesoautochtonous unit. These findings are not consistent with reconstructions that incorporate the entire Northern Sporades in the belt of Aegean high pressure rocks which have been subducted to great depth in Paleogene times (e.g. Figure 4. in Brun et al., 2016). The grade of metamorphism is rather consistent with shallow tectonic processes in an accretionary wedge which formed during the collision of Pelagonia and Rhodopia (Figure 2.11d).

The Mesoautochtonous unit and the upper formations of the Palouki unit were deposited in a convergent setting in front of the advancing thrusts of the Europe-derived units (Rhodopia) (Figures 11c and d). The upper formations of the Palouki unit were deposited coevally but at distance from the equivalent Mesoautochtonous formations (Matarangas, 1992) which is also reflected in the slightly different heavy mineral composition of the two flysch successions (Faupl et al., 1999). Following deposition of the flysch formations, the Palouki unit was thrust on top of the Mesoautochtonous unit (Figures 11d). The Ar/Ar age of the mylonitic sericite fabric $\left(\mathrm{S}_{2}\right)$ in the Turonian-Paleogene flysch is roughly 53Ma (Figure 2.9). Consequently, the deposition of the Mesoautochtonous and the Palouki units ceased prior to the Paleocene-Eocene boundary, and the units were subsequently transported to a depth of greenschist facies conditions (roughly 10-15 km) together with the subducting Pelagonian basement. Greenschist facies conditions suggests that the Mesoautochtonous and the Palouki units were detached from the downgoing plate by a thrust system and were incorporated in the accretionary wedge, which was evolving on top of the downgoing plate (Figure 2.11d). Similar greenschist facies syn- $\mathrm{D}_{2}$ metamorphic conditions of the Pelagonian and Glossa units as well as of the basal formation of the Palouki unit imply that these formations were also incorporated in the accretionary wedge instead of being subducted (Figure 2.11d). Ar/Ar fabric ages from the Pelagonian and Glossa units are somewhat ( 10 $\mathrm{Ma}$ ) older than the ones from the Mesoautochtonous unit (Figure 2.9) suggesting that these formations might have been buried earlier (latest Cretaceous-Early Paleocene), while the 
flysch units were still depositing in the foredeep basin. The partial activation of the erosional contact between the Mesoautochtonous and Pelagonian units (Figure 2.2, for details see Section 5.2) as top-SW shear zone (Figure 2.11d) is easiest explained assuming that this originally erosional contact has been dipping in the same direction than the thrusts of the accretionary wedge (Figure 2.11d).

Pressure recorded within the mylonitic metapelites, exposed between the Pelagonian and the Mesoautochtonous units is significantly higher compared to the Mesoautochtonous unit above and to the Pelagonian unit below; these units have only experienced greenschist facies metamorphism (Figure 2.11d). Explanations for such pressure differences depend on the approach in converting pressure to depth. Traditionally, pressure as recorded by mineral assemblages is interpreted in terms of overburden (lithostatic) pressure (e.g. Jolivet et al., 2003), whereas other authors (e.g. Schmalholz and Podladchikov, 2013) suggest that tectonic overpressure may be significant in some instances. These fundamentally different ways of interpreting the meaning of pressure inevitably leads to substantially different tectonic interpretations of the same P-T path recorded by the metamorphic rocks. In our case assuming that the recorded pressure corresponds to the lithostatic pressure demands a complicated tectonic model: a thin slice of metapelites needs to be subducted to much greater depth with respect to the over-and underlying units and subsequently exhumed in a way that accommodates a differential displacement and transports the blueschist-facies metapelites between the greenschist facies units. On the other hand, accounting for overpressure in the metapelites instead of assuming large differential displacements would provide a much simpler solution, which is also consistent with our observations. Numerical simulations of lithospheric shortening have demonstrated that pressure can significantly increase inside weak crustal shear zones (such as the one between the Pelagonian and the Mesoautochtonous units) to maintain a constant depth-averaged horizontal total stress and to fulfill the horizontal force balance across the shear zone (Moulas et al., 2014; Schmalholz and Podladchikov, 2013). Thus, we suggest that the high-pressure assemblage on Skopelos could be an example where tectonic overpressure inside a prograde, greenschist facies, weak shear zone has led to aerially restricted blueschist facies metamorphism related to top WSW shearing at the tectonic contact between the Pelagonian and the Mesoautochtonous units (Figure 2.11d).

\subsubsection{Top-NE exhumation of the accretionary wedge}

The simultaneous onset of exhumation and extension in the Aegean region suggests that these processes are intimately linked (Brun et al., 2016; Brun and Sokoutis, 2007, 2010). The switch from contraction to extension is commonly related to the subduction of buoyant continental block(s) and resulting initiation of slab-rollback during the Eocene (Brun and Faccenna, 2008). Slab-rollback resulted in trench retreat and related NE-SW extension in the upper plate. Top-NE shear zones localized in the Pelagonian zone (Figure 2.10b), top-NE regional detachment(s) in the Northern Cyclades (Gautier and Brun, 1994; Grasemann et al., 2012; Jolivet et al., 2010), and a top-SW regional detachment in Southern Rhodopia (Brun and Sokoutis, 2007; Dinter and Royden, 1993).

We correlate the top-NE ductile deformation of Skopelos with the early-stage exhumation of the Late-Cretaceous-Paleogene accretionary wedge. Our observations (Figure 2.3b) are consistent with the commonly observed top-NE exhumation in the Aegean region 
(Figure 2.10b) (Brun et al., 2016 and references therein). Latest Cretaceous-earliest Eocene $\mathrm{S}_{2}$ mylonitic fabrics (Figure 2.9) most likely formed during the tectonic burial of the rocks, setting an Early Eocene upper boundary for the possible onset of exhumation in case of Skopelos. This upper boundary is consistent with the 40-45 Ma onset of exhumation in Rhodopia (Brun and Sokoutis, 2007; Lips et al., 2000) and in the Ossa-Olympos-region (Lips et al., 1998; Schermer et al., 1990; Walcott, 1998). Younger, Eocene to Oligocene onset of exhumation has been inferred for the Pelion peninsula (Lips et al., 1999) as well as for the Cyclades (Brun et al., 2016; Jolivet and Brun, 2010; Jolivet et al., 2010; Lister and Forster, 2016; Uunk et al., 2018; Wijbrans et al., 1990) supporting the hypothesis that the southward migration of extensional and compressional domains was coupled to trench retreat leading to the southward decreasing age of exhumation (Jolivet and Brun, 2010).

Apatite fission track data (Hejl et al., 1999) suggest that the rocks of Skopelos have already been exhumed to a near-surface position by mid-Oligocene times. This implies that most of the exhumation took place between the late-Eocene and early-Oligocene. The ductile stage of exhumation on Skopelos was accommodated by small to medium-sized, top-NE shear zones and distributed top-NE shearing between the main structures (Figure 2.11f). The exact amount of exhumation accommodated by these structures remains uncertain, but could be quantified in the future with the specific dating of exhumation-related fabrics and zircon fission track dating. Later normal faulting is probably linked with the evolution of the North Aegean Trough, and is also likely to have played a significant role during final exhumation of the rocks to the surface.

\subsection{Conclusions}

The application of multi-scale structural analysis, metamorphic petrology, and white mica ${ }^{40} \mathrm{Ar} /{ }^{39} \mathrm{Ar}$ dating allowed to define two distinct episodes of tectonic burial and exhumation on the island of Skopelos.

- $\quad$ Early Cretaceous ( 105-135Ma) tectonic burial and exhumation affected the Pelagonian, Glossa, and the lowermost formation of the Palouki units and developed a first generation of isoclinal folds $\left(F_{1}\right)$ and a related foliation $\left(S_{1}\right)$. We correlate the top-NW and top-SE shearing and greenschist facies metamorphism of $\mathrm{D}_{1}$ with the underthrusting of the Pelagonian or Adriatic margin below the Vardar ophiolites. The structural and geochronological record of this underthrusting can be correlated up to the Internal Dinarides.

- Underthrusting was followed by exhumation and erosion of the Pelagonian margin. The exhumation of the Pelagonian, Glossa, and the lowermost formation of the Palouki units of Skopelos took place during the late Early Cretaceous and were subsequently transgressed by the younger sedimentary sequences from the latest Albian-Early Cenomanian ( 100-95 Ma).

- $\quad$ Latest Cretaceous-Early Eocene ${ }^{40} \mathrm{Ar} /{ }^{\beta 9} \mathrm{Ar}$ white mica ages of mylonitic $\mathrm{S}_{2}$ foliations attest to a second phase of burial and exhumation of Skopelos. A second generation of isoclinal folds $\left(\mathrm{F}_{2}\right)$ and tectonic foliation $\left(\mathrm{S}_{2}\right)$ developed during topSW and following top-NE shearing under greenschist facies conditions. 
- The Late Cretaceous-Paleogene sedimentary cycle exposed on Skopelos was deposited in a compressional setting and was buried during subduction of the Pelagonian basement to greenschist facies conditions.

- We propose that all the rocks of Skopelos were detached from the downgoing Pelagonian basement by top-SW thrusts and incorporated in an accretionary wedge that evolved above the downgoing plate during Paleogene times. Top-SW shear fabrics formed during the tectonic burial of the rocks, while opposite top-NE fabrics formed during the first stage of extensional exhumation.

- A shear zone in Al-rich metapelites records significantly higher pressure than the overlying Mesoautochtonous and the underlying Pelagonian units. In our view the pressure difference could be an example of tectonic overpressure inside a prograde, weak shear zone.

\subsection{Appendix}

\begin{tabular}{|c|c|c|c|c|c|c|c|}
\hline Phase & Phengite & \multicolumn{4}{|c|}{ Chloritoid } & \multirow{2}{*}{\begin{tabular}{|l|} 
Carpholite \\
incl. in ctd \\
\end{tabular}} & \multirow{2}{*}{$\begin{array}{c}\text { Hematite } \\
\text { matrix }\end{array}$} \\
\hline Notes & matrix & syn-pc & syn-pr & pre-pc & pre-pr & & \\
\hline wt.\% oxides & & & & & & & \\
\hline $\mathrm{SiO}_{2}$ & 46.9 & 24.03 & 24.74 & 25.04 & 25.29 & 36.45 & \\
\hline $\mathrm{TiO}_{2}$ & & & & & & & 0.86 \\
\hline $\mathrm{Al}_{2} \mathrm{O}_{3}$ & 36.02 & 40.87 & 41.64 & 41.74 & 42.03 & 33.14 & \\
\hline $\mathrm{Fe}_{2} \mathrm{O}_{3}$ & & & & & & & 96.56 \\
\hline $\mathrm{FeO}$ & 2.11 & 18.16 & 17.81 & 19.39 & 18.09 & 10.32 & \\
\hline $\mathrm{MnO}$ & & 6.75 & 5.57 & 7.01 & 6.52 & 0.98 & 0.56 \\
\hline $\mathrm{MgO}$ & 0.7 & 2.59 & 3.2 & 2.47 & 2.89 & 5.67 & \\
\hline $\mathrm{K}_{2} \mathrm{O}$ & 9.6 & & & & & & \\
\hline $\mathrm{Na}_{2} \mathrm{O}$ & 0.56 & & & & & & \\
\hline Total & 95.89 & 92.4 & 92.96 & 95.65 & 94.82 & 86.56 & 97.98 \\
\hline Cations & & & & & & & \\
\hline $\mathrm{Si}$ & 3.09 & 1.99 & 2.01 & 2.01 & 2.03 & 1.95 & \\
\hline $\mathrm{Ti}$ & & & & & & & 0.02 \\
\hline $\mathrm{Al}$ & 2.8 & 3.98 & 3.99 & 3.94 & 3.97 & 2.09 & \\
\hline $\mathrm{Fe}^{3+}$ & & & & & & & 1.97 \\
\hline $\mathrm{Fe}^{2+}$ & 0.12 & 1.26 & 1.21 & 1.3 & 1.21 & 0.46 & \\
\hline Mn & & 0.47 & 0.38 & 0.48 & 0.44 & 0.04 & 0.01 \\
\hline Mg & 0.07 & 0.32 & 0.39 & 0.3 & 0.35 & 0.45 & \\
\hline $\mathrm{K}$ & 0.81 & & & & & & \\
\hline $\mathrm{Na}$ & 0.07 & & & & & & \\
\hline Total & 6.95 & 8.02 & 7.99 & 8.02 & 7.99 & 5 & 2 \\
\hline Mg\# & 0.368 & 0.203 & 0.244 & 0.188 & 0.224 & 0.495 & \\
\hline Oxygens & 11 & 12 & 12 & 12 & 12 & 8 & 3 \\
\hline
\end{tabular}

Appendix 2.1. Representative mineral analyses of sample Sko-3.3. Syn: syn-mylonitic; pre: premylonitic; pc: porphyroblast core; pr: porphyroblast rim. 


\begin{tabular}{|l|r|}
\hline wt.\% \\
\hline $\mathrm{SiO}_{2}$ & 62.66 \\
$\mathrm{TiO}_{2}$ & 0.99 \\
$\mathrm{Al}_{2} \mathrm{O}_{3}$ & 20.21 \\
$\mathrm{FeO}$ & 5.49 \\
$\mathrm{MnO}$ & 0.55 \\
$\mathrm{MgO}$ & 1.11 \\
$\mathrm{CaO}$ & 0.31 \\
$\mathrm{Na}_{2} \mathrm{O}$ & 0.31 \\
$\mathrm{~K}_{2} \mathrm{O}$ & 4.79 \\
$\mathrm{P}_{2} \mathrm{O}_{5}$ & 0.02 \\
LOI & 3.56 \\
Total & 100.00 \\
\hline
\end{tabular}

Appendix 2.2. Whole-rock composition of sample Sko-3.3

\begin{tabular}{|c|c|c|c|c|c|}
\hline No. & Lat & Lon & Method & Unit & Description \\
\hline 1.2 & 39.164 & 23.627 & single grain & Glossa & $\begin{array}{c}\text { brown schistose metasandstone with } \\
\text { metaconglomerate layers }\end{array}$ \\
\hline 7.3 & 39.163 & 23.640 & single grain & Pelagonian & grey phyllitic schist \\
\hline 8.1 & 39.174 & 23.650 & single grain & Pelagonian & $\begin{array}{l}\text { heavily deformed light brown pyhillite } \\
\text { with metasandstone layers }\end{array}$ \\
\hline 12.4 & 39.087 & 23.754 & single grain & M Flysch & $\begin{array}{c}\text { grey metasandstone with large detrital } \\
\text { white micas }\end{array}$ \\
\hline 13.2 & 39.104 & 23.741 & single grain & P Flysch & $\begin{array}{l}\text { brown phyllite with large detrital white } \\
\text { micas }\end{array}$ \\
\hline 13.6 & 39.128 & 23.710 & single grain & M Flysch & $\begin{array}{c}\text { brown phyllite with coarser } \\
\text { metasandstone layers }\end{array}$ \\
\hline 17.5 & 39.124 & 23.758 & single grain & P Flysch & $\begin{array}{c}\text { brown phyllite with large detrital white } \\
\text { micas }\end{array}$ \\
\hline 2.2 & 39.176 & 23.634 & fabric & Glossa & $\begin{array}{c}\text { brown phyllitic schist with well- } \\
\text { developed S2 sericitic foliation }\end{array}$ \\
\hline 3.3 & 39.128 & 23.677 & fabric & M Metapelites & $\begin{array}{l}\text { purple to grey metapelites with mylonitic } \\
\text { S2 foliation }\end{array}$ \\
\hline 7.1 & 39.165 & 23.634 & fabric & Pelagonian & $\begin{array}{l}\text { grey phyllitic schist with well-developed } \\
\text { S1 and S2 foliations }\end{array}$ \\
\hline 7.2 & 39.167 & 23.635 & fabric & Glossa & grey to light pink phyllitic schist \\
\hline 12.3 & 39.085 & 23.753 & fabric & M Flysch & $\begin{array}{l}\text { grey phyllite with well-developed S2 } \\
\text { sericitic foliation }\end{array}$ \\
\hline
\end{tabular}

Appendix 2.3. Location and description of dated samples. No.: sample number, Lat: Latitude, Lon: Longitude, M: Mesoautochtonous, P: Palouki. 


Chapter 3. Strain localization during burial and
exhumation of the continental upper crust: A case
study from the Northern Sporades (Pelagonian thrust
sheet, Greece)

${ }^{2}$ This chapter is based on Porkoláb, K., Willingshofer E., Sokoutis D., Wijbrans J., 2020, Global and Planetary Change, 194, 103292. 


\subsection{Introduction}

The burial and exhumation of continental rocks in subduction and collision settings has received significant attention during the last decades. Large-scale analogue and numerical models have demonstrated, that the relative strength (rheology) of the upper crust, lower crust, and lithospheric mantle of continental plates in subduction/collision systems determines where strain localizes and hence controls the geometry of the evolving mountain belt (Sokoutis and Willingshofer, 2011; Vogt et al., 2017; Vogt et al., 2018). In such settings, subduction of continental crust is often followed by post-orogenic extension that is one of the key mechanisms driving the exhumation of deeply buried rocks (e.g. Dewey, 1988; Gautier and Brun, 1994; Lister et al., 1984; Wernicke, 1981). The onset of extensional deformation is often explained by a change in slab dynamics from advancing to retreating (with respect to the upper plate of the subduction system) (Brun and Faccenna, 2008; Brunet et al., 2000; Le Pichon et al., 1981). The distribution of post-orogenic extension is substantially influenced by crustal or lithospheric heterogeneities such as weakness zones inherited from the shortening phase (nappe contacts and suture zones). These weakness zones are prone to be reactivated as extensional faults and shear zones, and may lead to the formation of extensional detachments (e.g. Balázs et al., 2017; Daniel et al., 1996; Jolivet et al., 2010; Patel et al., 1993). Detachments accommodate at least several 10s of kilometers of displacement and juxtapose high-grade next to low-grade metamorphic rocks (metamorphic core complexes) (Gautier and Brun, 1994; Reynolds and Spencer, 1985; Wernicke, 1981). The mechanics of detachment faulting and thus the localized mode of post-orogenic extension have been studied extensively (e.g. Axen et al., 1995; Brun et al., 2018; GarcíaDueñas et al., 1992; Jolivet et al., 2010; Selverstone, 1988), however, less attention have been paid to regions where extensional deformation never resulted in the formation of a major detachment, but is distributed over multiple, smaller shear zones. As a consequence, extensional deformation does not produce easily observable jumps in the metamorphic grade. Furthermore, the relation between the distribution of contractional deformation during nappe stacking and the distribution of subsequent extensional deformation remains unexplored, especially on a smaller, upper crustal scale. 


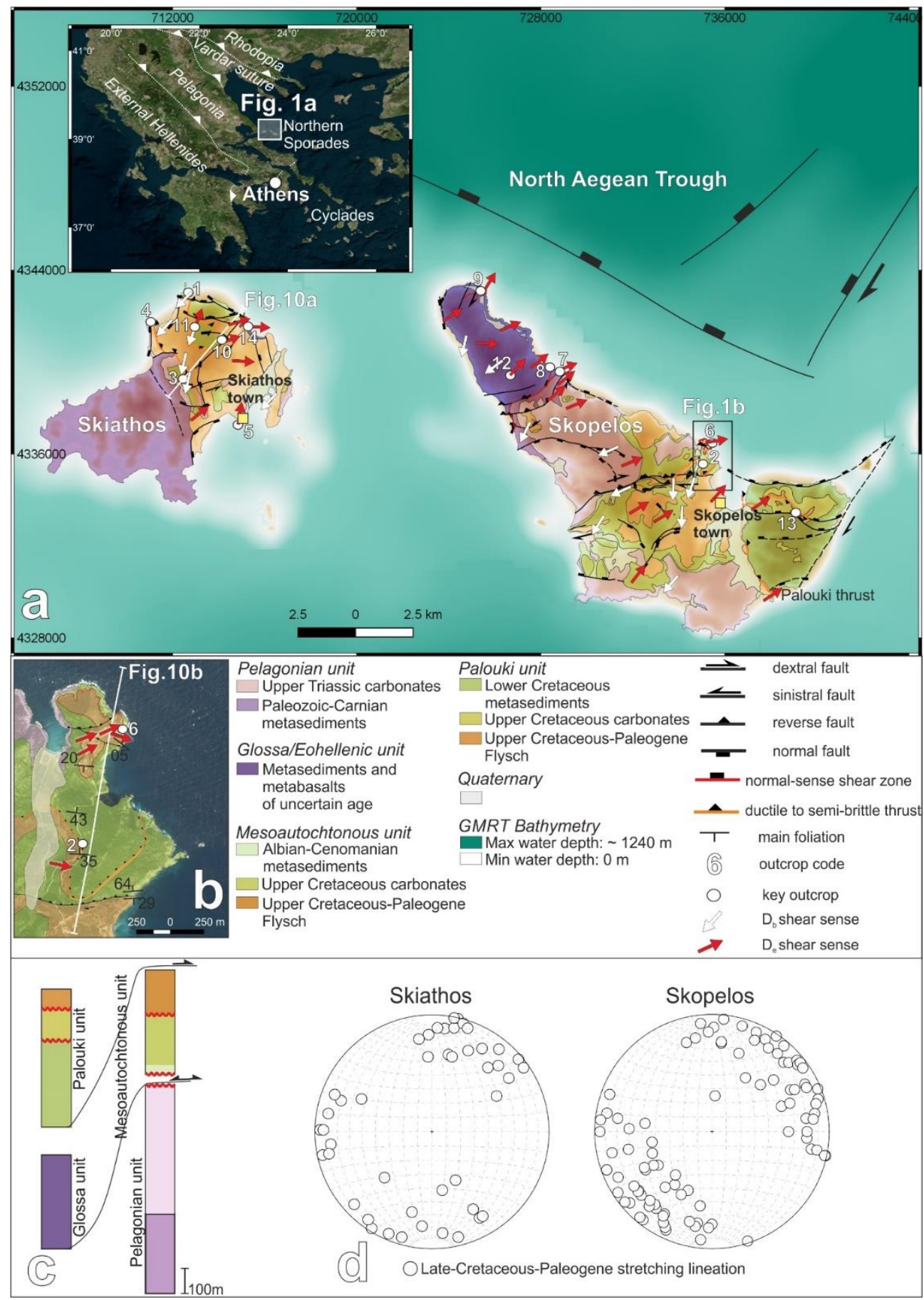

Figure 3.1. (a) Geological maps of Skiathos (after Ferentinos, 1973) and Skopelos (after Porkoláb et al., 2019b) highlighting the locations of key outcrops discussed in the text; (b) Magnified detail of Figure 3.1a; (c) Tectono-stratigraphic column of Skiathos and Skopelos displaying the approximate outcropping thicknesses of the formations and the tectonic units established prior to 
this study (Ferentinos, 1973; Heinitz and Richter-Heinitz, 1983; Jacobshagen and Wallbrecher, 1984; Matarangas, 1992); (a) Stereographic projection of stretching lineations measured on Skiathos and Skopelos.

We focus our study on the metasedimentary cover of the Pelagonian thrust sheet (Internal Hellenides) outcropping on the islands of Skiathos and Skopelos (Figure 3.1). Different to Rhodopia in the north and the Cyclades in the south, where the extensional style is of localized core-complex type (Brun and Sokoutis, 2007; Brun and Sokoutis, 2018; Gautier and Brun, 1994; Jolivet et al., 2010), extension in our study area is distributed over multiple small-scale (up to a few 10 meters thick) extensional shear zones. We aim to understand strain localization on the scale of the Pelagonian metasedimentary cover formations (Late Paleozoic to Paleogene), from the initial stages of shortening, through nappe stacking, to extensional exhumation. We present detailed structural geological analyses supplemented by ${ }^{40} \mathrm{Ar} /{ }^{39} \mathrm{Ar}$ dating of key shear zones and discuss the kinematics of burial exhumation and the importance of mechanical stratigraphy and structural inheritance. We revise the nature of contacts between different geological units on the islands of Skiathos and Skopelos, identifying multiple thrusts and normal-sense shear zones that were previously mapped as stratigraphic contacts (Ferentinos, 1973; Heinitz and Richter-Heinitz, 1983; Matarangas, 1992). We compare our findings on the conditions of distributed extensional shearing with type locations of localized, core-complex-style extension to develop the understanding of post-orogenic extensional strain localization.

\subsection{Tectonic and Geological setting}

The Aegean is an excellent location for investigating the burial and exhumation of continental crust, as Cretaceous to Early Paleogene nappe stacking and metamorphism of continental crust was followed by extensional exhumation starting during the Eocene (Brun and Sokoutis, 2007; van Hinsbergen and Schmid, 2012; Jolivet and Brun, 2010). This burialexhumation cycle occurred in context of Africa - Europe convergence, which also led to the closure of the Mesozoic Neotethys ocean and the subduction and accretion of largely upper crustal continental thrust sheets (Pelagonian, Pindos, Gavrovo-Tripolitza, and Ionian thrust sheets) derived from the Adria microplate (Brunn et al., 1976; Jacobshagen, 1978; Jolivet and Brun, 2010; Ricou et al., 1998; Schmid et al., 2019; van Hinsbergen et al., 2005). The accretion of buoyant material to the upper plate (Rhodopia i.e. Eurasia) triggered the retreat of the subduction trench resulting in upper plate extension (Brun and Faccenna, 2008). Following the initiation of slab-rollback, early-stage extension was accommodated by a major top-SW detachment in Rhodopia (Brun and Sokoutis, 2007; Brun and Sokoutis, 2018; Dinter and Royden, 1993; Sokoutis et al., 1993), and a top-NE detachment(s) at the Cyclades (Gautier and Brun, 1994; Jolivet et al., 2010), implying that initial extension was highly localized in those regions. In Neogene times, the rate of slab rollback substantially accelerated following the tearing of the Hellenic slab, resulting in a more distributed pattern of brittle extensional structures related to an increase in mechanical coupling among layers, throughout the Aegean (Brun et al., 2016; Brun, 1999). 
The Northern Sporades island group is part of the Pelagonian zone in Greece (Aubouin et al., 1976; Jacobshagen, 1978) and consists of three major islands (Skiathos, Skopelos, and Alonnisos) that are largely made up by low-grade metasediments (Jacobshagen and Wallbrecher, 1984). In the Northern Sporades, the Pelagonian zone consists predominantly of metamorphosed cover sequences and upper crustal rocks that were decoupled from the subducting lower crust and lithospheric mantle during the collision with Eurasia (e.g. Jolivet and Brun, 2010; van Hinsbergen et al., 2005). The oldest outcropping formations are Paleozoic meta-siliciclastics locally intruded by granites, which are overlain by thick $(\sim 3 \mathrm{~km})$ Middle Triassic to Middle Jurassic platform carbonates (dolostones and limestone marbles) and a much thinner Middle-Late Jurassic deep water sequence (radiolarites and greywackes). This succession was deposited on the east-facing Pelagonian/Adriatic passive margin (De Bono, 1998; De Bono et al., 2001; Scherreiks, 2000; Scherreiks et al., 2010) and is structurally overlain by obducted Middle-Late Jurassic ophiolites and sub-ophiolitic metasediments that originated in the eastward enclosing Neotethys ocean (Dimo-Lahitte et al., 2001; Scherreiks, 2000; Spray et al., 1984). On the Northern Sporades, the ophiolites that are almost completely eroded (Bortolotti et al., 2013 and references therein; Jacobshagen and Wallbrecher, 1984), and comprise together with the underlying sub-ophiolitic metasediments the Eohellenic nappe (Jacobshagen et al., 1978; Jacobshagen and Wallbrecher, 1984) or the Western-Vardar Ophiolitic unit (Schmid et al., 2019). On Skopelos, the metamafic and metasedimentary rocks of the Eohellenic nappe are referred to as the "Glossa unit", which covers the northern part of the island (Figure 3.1a) (Matarangas, 1992). On Skiathos, the Glossa unit was not distinguished on the maps of Ferentinos (1973) or Heinitz and RichterHeinitz (1983), and it seems to be largely eroded. The Paleozoic-Mesozoic formations below the ophiolites were metamorphosed during the Early Cretaceous, probably related to a phase of continental subduction below the oceanic upper plate (Kilias et al., 2010; Lips et al., 1998; Lips et al., 1999; Most, 2003; Porkoláb et al., 2019b). Burial was followed by exhumation, regional erosion, and the deposition of Late Cretaceous-Paleogene sedimentary formations. On the Northern Sporades, the Late Cretaceous - Paleogene formations comprise the Mesoautochtonous unit deposited on Triassic and Jurassic rocks, and the Palouki unit, which was thrust on top of the Mesoautochtonous unit following the deposition of the Upper Cretaceous - Paleogene flysch (Jacobshagen and Wallbrecher, 1984; Matarangas, 1992) (Figure 3.1c). These units consist of a transgressive sequence of coarse siliciclastic sediments which are followed by shallow water carbonates (dominantly rudist-bearing limestones), and a quartz-rich flysch succession marking the final closure of the Neotethys ocean (Ferentinos, 1973; Jacobshagen and Wallbrecher, 1984; Matarangas, 1992). On Skiathos, Vidakis (1995) re-interpreted the entire flysch formation as the Eohellenic nappe, however, we consider this erroneous and use the original classification of Ferentinos (1973). During latest Cretaceous - Early Paleogene times, all the formations of the Northern Sporades were affected by tectonic burial leading to greenschist to locally blueschist facies metamorphism, followed by the erosion of the nappe stack and extensional exhumation (Porkoláb et al., 2019b). In the following sections we present our results on the strain localization during this phase of burial and exhumation on the islands of Skiathos and Skopelos. 


\subsection{Strain localization and the kinematics of deformation}

Our fieldwork included detailed mapping of ductile and brittle structures focusing on the kinematics of deformation and delineating the main zones of strain localization. Mapping was based on detailed stratigraphic studies of Skiathos (Ferentinos, 1973; Heinitz and Richter-Heinitz, 1983) and Skopelos (Matarangas, 1992). Regarding the structural build-up of Skopelos, we follow the new map of Porkoláb et al. (2019b). We present the results of our structural mapping in the form of geological maps of the two islands (Figure 3.1), interpretations of key outcrops (Figures 3.2, 3.3, 3.4, 3.5, 3.6 and 3.7), and cross sections (Figure 3.10).

The pre-Upper Cretaceous formations of the Northern Sporades (the Paleozoic to Middle Triassic metaclastics and Upper Triassic platform carbonates of the Pelagonian unit, and the Glossa unit) preserve structural elements related to an Early Cretaceous tectonometamorphic event. In these rocks, the Late-Cretaceous - Paleogene tectono-metamorphic event is already $\mathrm{D}_{2}$, while in the Upper Cretaceous - Paleogene lithologies it is the first phase, $\mathrm{D}_{1}$ (Porkoláb et al., 2019b). In the present study, we only focus on the Late Cretaceous Paleogene burial-exhumation cycle which affected all the outcropping formations on Skiathos and Skopelos. Contraction during tectonic burial and extensional exhumation are from now on indexed as $D_{b}$ and $D_{e}$, respectively. Regarding the distribution of deformation in a given rock volume, we use the expressions "localized" and "distributed" always with respect to the scale of observation. Therefore, what is described as "localized" deformation on the scale of the islands, may be part of a "distributed" deformation pattern on a larger scale. 


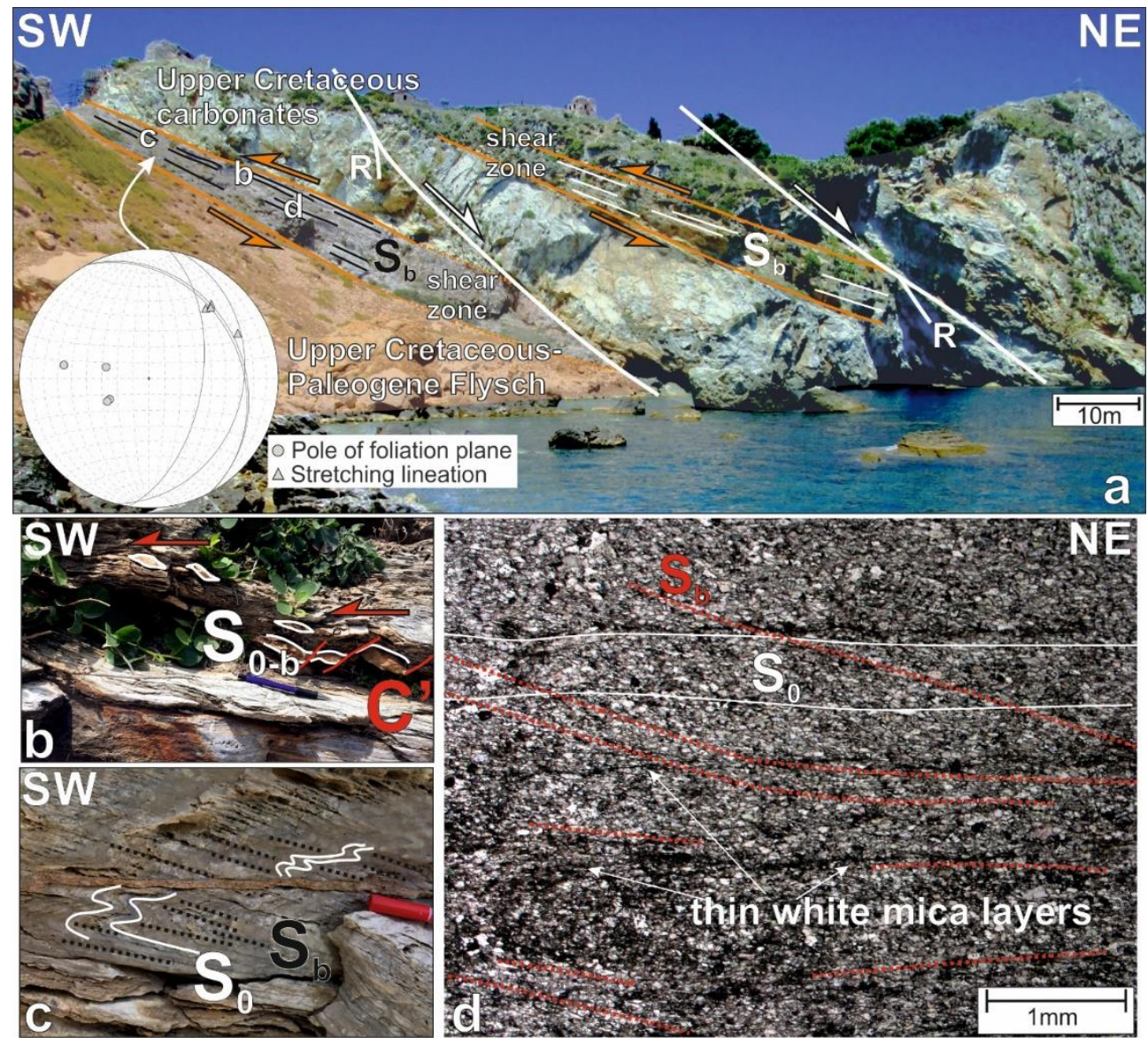

Figure 3.2. (a) Top-SW reverse-sense shear zone (Kastro shear zone) at Location 1 emplacing the Upper Cretaceous carbonates on top of the Upper Cretaceous-Paleogene Flysch. Stereographic projection of structural measurements is included; (b) C'-type shear bands and $\sigma$-clasts showing top-SW sense of shear, pencil for scale; (c) Relation between the tightly folded $\mathrm{S}_{0}$ bedding of the marble and the newly formed $S_{b}$ foliation; (d) Plain polarized microscope image of the sample from Location 1 showing the microscale structure of the marble mylonite. Red lines highlight the shape-preferred orientation of the calcite crystals ( $\sim 95 \%$ of the rock mass) that is slightly oblique to the $\mathrm{S}_{0}$ original bedding (white lines). Discontinuous white mica layers ( $\sim 5 \%$ of the rock mass) follow the $\mathrm{S}_{0}$ bedding.

\subsubsection{Contractional structures related to tectonic burial $\left(D_{b}\right)$}

All the geological units of the islands are characterized by a penetrative tectonic foliation $\left(\mathrm{S}_{\mathrm{b}}\right)$ which is the axial planar cleavage of $\mathrm{F}_{\mathrm{b}}$ tight to isoclinal folds. The foliation is poorly or not developed in the dolomitized parts of the Upper Triassic carbonates, but especially well-developed in the calcite marble layers (Figures 3.2 and 3.3). Up to a few hundreds of meters thick calcite marble layers are found in the Upper Triassic part of the Pelagonian unit, and in the Cenomanian - Turonian part of the Mesoautochtonous unit. Thin 
marble layers are also found in the Glossa unit, which also show well-developed $S_{b}$ foliation planes (Figures 3.6 and 3.7b). The $S_{b}$ foliation in the metaclastic rocks (Paleozoic - Carnian part of the Pelagonian unit, some parts of the Glossa unit, and the Upper Cretaceous Paleogene flysch) is largely defined by recrystallized white micas, chlorite, and occasionally oriented quartz observed macroscopically and in thin sections. The penetrative foliation carries a stretching lineation $\left(\mathrm{L}_{b}\right)$ which is defined by stretched calcite aggregates in marbles, and white mica or chlorite in the metaclastic rocks and the metabasalts of the Glossa unit. The best developed stretching lineations are observed in calcite marbles, while stretching lineations in the Upper Cretaceous - Paleogene flysch are often poorly developed. The general trend of stretching lineations is NE-SW on both islands. $\mathrm{L}_{\mathrm{b}}$ stretching lineations are generally associated with top-SW to top-S sense of shear described in detail in section 3.1.1., observed on both islands (Figure 3.1). These kinematic directions are typically distributed over the entire thickness of the strata. Additionally, localized $\mathrm{D}_{\mathrm{b}}$ deformation was also observed in a few, 5-15 m thick shear zones showing a mylonitic foliation, well-developed stretching lineations, and more intense shear fabric compared to the ductile strain recorded outside of these zones. At such shear zones, the Cenomanian - Turonian marbles are found on top of the Late Cretaceous - Paleogene flysch unit, or Upper Triassic Pelagonian carbonates on top of the Upper Cretaceous carbonates or flysch of the Mesoautochtonous unit (Figure 3.1). Such relationships are observed on both islands at multiple locations, providing the clearest marker for post-Upper Cretaceous thrusting on the Northern Sporades (Figure 3.1).

\subsubsection{Key outcrops}

On Skiathos, the Cenomanian - Santonian carbonates of the Mesoautochtonous unit are in many cases found on top of the younger flysch formation (Figure 3.1a). Previous works focusing on lithological mapping defined these as stratigraphic contacts (Ferentinos, 1973; Heinitz and Richter-Heinitz, 1983), not explaining the structural position of the formations.

Location 1 (Kastro shear zone) (Figure 3.2a) provides the best exposed section to study this relationship at the historical village of Kastro. The village is built on a cliff made up by the Cenomanian - Santonian carbonates which dip $30-45^{\circ}$ to the NE. The flysch (dark grey to brown quartz-rich metasandstones, slates, and phyllites) is outcropping below the carbonates, with an identical orientation. The carbonates show an alternation of well-foliated and massive parts (Figure 3.2a), while the flysch carries a moderately developed main foliation $\left(S_{b}\right)$ subparallel with the $S_{0}$ compositional layering (bedding), and a weakly developed NE-plunging stretching lineation. The two formations are separated by $5-10 \mathrm{~m}$ thick zone with a very closely spaced mylonitic foliation and intense stretching lineations. The mylonitic foliation is NE dipping and carries a down-dip stretching lineation. Both structural elements are similarly oriented as the weakly or moderately developed $S_{b}$ and $L_{b}$ in the flysch below, indicating that the tectonic transport along the shear zone was subparallel to the orientation of the $S_{0}$ sedimentary foliation. The shear zone consists of nearly pure calcite marble with minor amount (estimated as $<5 \%$ based on the thin section) of finegrained white micas found in discontinuous layers along the $S_{0}$ bedding (Figure 3.2d). The original bedding is preserved, suggesting that the protolith of the marble mylonite was a wellbedded rather than a massive limestone (Figure 3.2a). Shape-preferred orientation of the calcite crystals attesting to dynamic recrystallization defines the $S_{b}$ foliation that makes a small $\left(10-20^{\circ}\right)$ angle to the $\mathrm{S}_{0}$ bedding and defines a $\mathrm{SW}$-ward structural vergence (Figure 
3.2d). This agrees with asymmetric boudinage and $\sigma$-clasts showing top-SW sense of shear (Figure 3.2b). A similar zone of very well-foliated marble was identified higher up in the outcrop (Figure 3.2a). The shear zones are cut by two northerly-dipping normal faults which belong to a later phase of extension. The same top-SW shear zone (Figure 3.2a) can be followed from Location 1 towards the South, outcropping at the base of the carbonate hilltops (Figure 3.1a).
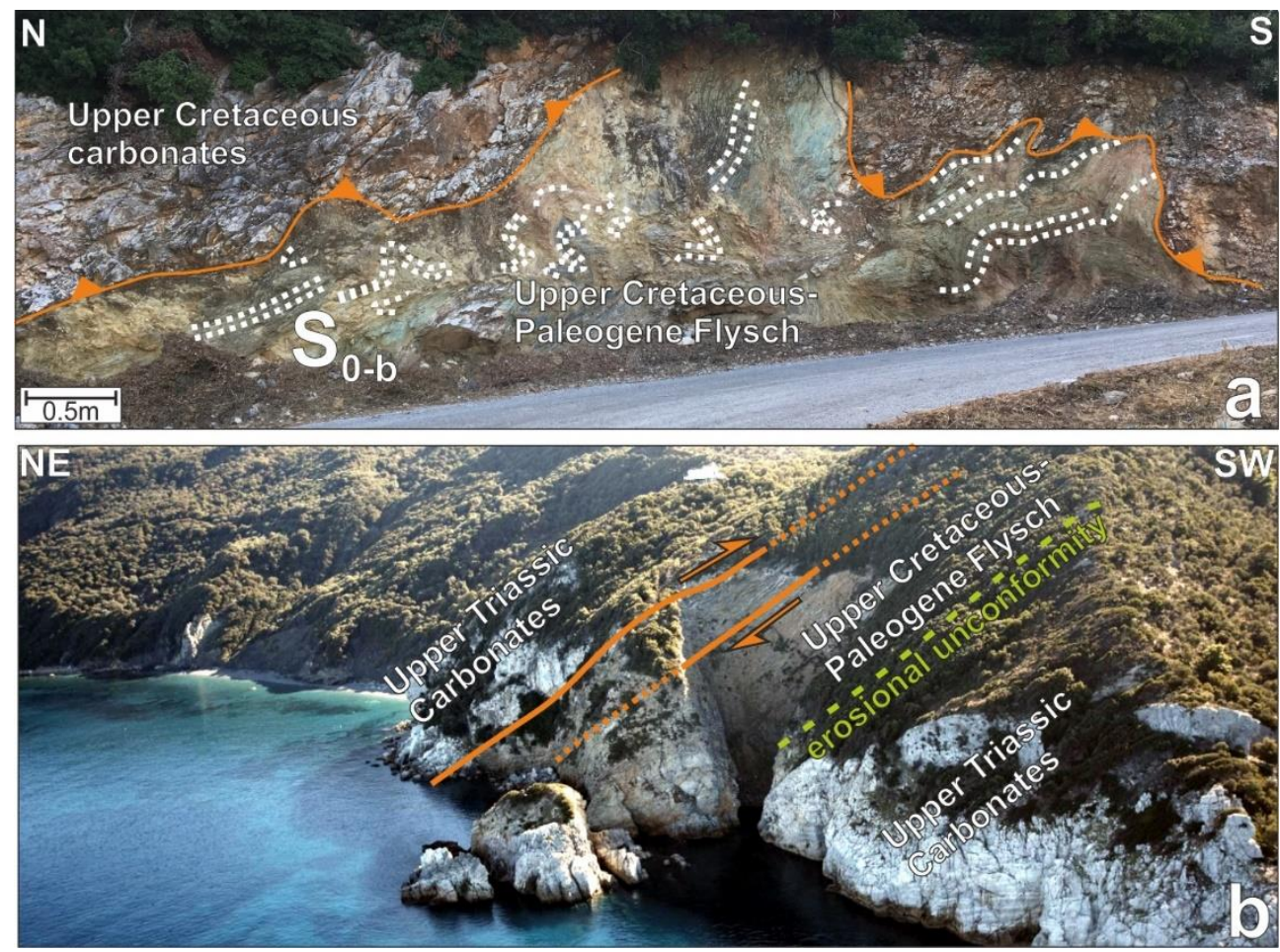

Figure 3.3. Key outcrops displaying reverse-sense shear zones. For locations see Figure 3.1; (a) Folded nappe contact at Location 2 between the Upper Cretaceous carbonates and the Upper Cretaceous-Paleogene Flysch; (b) Aerial view (photo from tripinview.com) of a reverse-sense shear zone at Location 4 emplacing the Upper Triassic carbonates on top of the Upper CretaceousPaleogene Flysch.

A similar relationship between the same units is found on the island of Skopelos, at Location 2 (Figures 3.1b and 3.3a). This contact was previously mapped as a stratigraphic contact (Matarangas, 1992), but has recently been identified as a thrust emplacing the carbonates on top of the flysch (Porkoláb et al., 2019b). However, the contact and the key structural elements are difficult to analyze and measure, since it has been overprinted by younger deformation phases as shown by the folded, irregular, and brecciated nature of the outcrop (Figure 3.3a) and the different structural elements cutting through nearby (Figure 3.1b). Both the carbonates and the flysch have a well-developed $S_{b}$ tectonic foliation, implying that at least one stage of thrusting took place under ductile conditions. To delineate the main structure, detailed mapping of the area was performed, showing that the thrust is dipping in a northerly direction, making a highly curved intersection with the topography (Figures 3.1b and 3.3a). The orientation of the thrust and the $\mathrm{S}_{0}-\mathrm{S}_{\mathrm{b}}$ composite foliation in the 
surrounding outcrops point to a low-angle thrust geometry (Figures 3.1b and 3.3a). The carbonates are characterized by a well-developed tectonic foliation and stretching lineation. However, the $\mathrm{L}_{b}$ stretching lineations that belong to the thrusting have been overprinted by $\mathrm{L}_{\mathrm{e}}$ stretching lineations, which locally trend E-W and are associated with top-E sense of shear (Figure 3.1b). The general orientation of the thrust and the foliation (N-dipping) in the surrounding rocks, and the frequently observed top-S shearing in the Mesoautochtonous unit on Skopelos (Figure 3.1) suggests that the original $\mathrm{D}_{\mathrm{b}}$ transport direction at Location 2 was similar to Location 1 on Skiathos, top-S or SW.

Location 3 and 4 on Skiathos exhibit a contact where Upper Triassic carbonates of the Pelagonian unit are lying on top of the Mesoautochtonous unit; in case of Location 3 on the Cenomanian-Santonian carbonates, while in case of Location 4 on the Upper CretaceousPaleogene flysch (Figure 3.1a). At Location 3, Upper Triassic dolomite boulders are found on top of the hill. The dolomites overlie a zone of 5-10 m thick calcite marble with a very closely spaced mylonitic foliation $\left(\mathrm{S}_{\mathrm{b}}\right)$ that is dipping $\sim 30^{\circ}$ to the NE. The mylonitic foliation carries a well-developed N-S trending stretching lineation associated with top-S sense of shear based on asymmetric calcite aggregates and C' shear bands. The marble mylonites overlie the Upper Cretaceous rudist-bearing carbonates with a less intense $\mathrm{S}_{0-\mathrm{b}}$ foliation that has the same, NE-dipping orientation as the mylonites above. The marble mylonites clearly define a shear zone of highly localized strain during top-S ductile thrusting $\left(D_{b}\right)$, similarly to Location 1.

The shear zone is difficult to follow towards the NE due to vegetation and steep topography; however, it crops out on the shoreline cliffs at Location 4 (Figures 3.1a and $3.3 b$ ). Here the footwall unit of the ductile thrust is the Upper Cretaceous - Paleogene flysch, which directly overlies the Upper Triassic carbonates with an erosional unconformity (Figure 3.3b). The shear zone is delineated by a very well-foliated part below the massive Upper Triassic carbonates in the hangingwall. The white color of the well-foliated part implies that most of the ductile strain localized in carbonate material similarly to Location 1 or Location 3. The shear zone is subparallel with the main foliation of the outcrop (Figure 3.3b).

\subsubsection{Extensional structures related to exhumation $\left(D_{e}\right)$}

Structures that are related to Top-S to SW ductile thrusting and distributed shearing accommodated tectonic burial $\left(\mathrm{D}_{\mathrm{b}}\right)$ and are often pervasively overprinted by structures related to the extensional exhumation of the rocks from ductile to brittle conditions $\left(\mathrm{D}_{\mathrm{e}}\right)$. Ductile $D_{e}$ shearing did in most cases not lead to the formation of a separate $S_{e}$ foliation. Instead, shearing occurred parallel to the already existing $S_{b}$ foliation planes, resulting in the deformation of the $\mathrm{S}_{\mathrm{b}}$ foliation (Figures 3.4, 3.5, 3.6, and 3.7). $\mathrm{L}_{\mathrm{e}}$ stretching lineations trend on average NE-SW (Figure 3.1) and are defined by the same minerals as $\mathrm{L}_{\mathrm{b}}$ such as chlorite, white micas, calcite, and quartz. Therefore, $\mathrm{L}_{b}$ and $\mathrm{L}_{\mathrm{e}}$ only differ on the sense of shear, which is generally top-NE in case of $D_{e}$ and top $S W$ for $D_{b}$, respectively (Figure 3.1). Top-NE ductile shearing was observed in numerous outcrops on Skopelos and Skiathos (Figure 3.1a) and is not restricted to shear zones, attesting to a distributed mode of deformation during $D_{e}$ phase. Zones of localized $\mathrm{D}_{\mathrm{e}}$ strain (i.e. top-NE shear zones) showing a transition from ductile to brittle shearing have been mapped as well and are presented in details in the following section. In zones of localized $D_{e}$ shear, the meta-basalts of the Glossa unit and 
occasionally the Upper Cretaceous - Paleogene flysch formation are heavily chloritized (Figures 3.7b and c). Strain localization was observed at several inherited reverse-sense shear zones (Figures 3.6b and 3.7a) and stratigraphic contacts (Figures 3.4, 3.5, 3.6c, and 3.6d). $\mathrm{D}_{\mathrm{e}}$ shear zones are parallel/subparallel with the $\mathrm{S}_{0 \text {-b }}$ composite foliation and therefore do not cut out major parts of the stratigraphy. Differences in the metamorphic grade between the footwall and hangingwall of $\mathrm{D}_{\mathrm{e}}$ shear zones were also not observed. Ductile top-NE shearing was followed by asymmetric, semi-brittle to brittle, northerly dipping normal faulting observed in many outcrops, providing clear evidence for the extensional nature of top-NE shearing and the gradual change in the deformation conditions from ductile to brittle (Figures $3.4,3.5,3.6$, and 3.7c-e). These northerly dipping normal faults are often tilted and link to pre-existing, ductile to brittle, normal-sense shear zones with similar kinematics (Figures 3.4 and 3.5). Asymmetric (northerly dipping) normal faulting was followed by more symmetric normal faulting (northerly and southerly dipping) as shown by our dataset of mesoscale normal faults measured on both islands (Figure 3.8). Two main sets of normal faults can be delineated with no clear overprinting relations between them; one trending NE-SW, and the other trending NW-SE (Figure 3.8). The major normal faults (with at least a few tens of meters of displacement, e.g. on Figure 3.5a) have been mapped and are presented on Figure 3.1, showing that the majority of map-scale normal faults are trending $\sim$ NW-SE (Figure 3.1). 


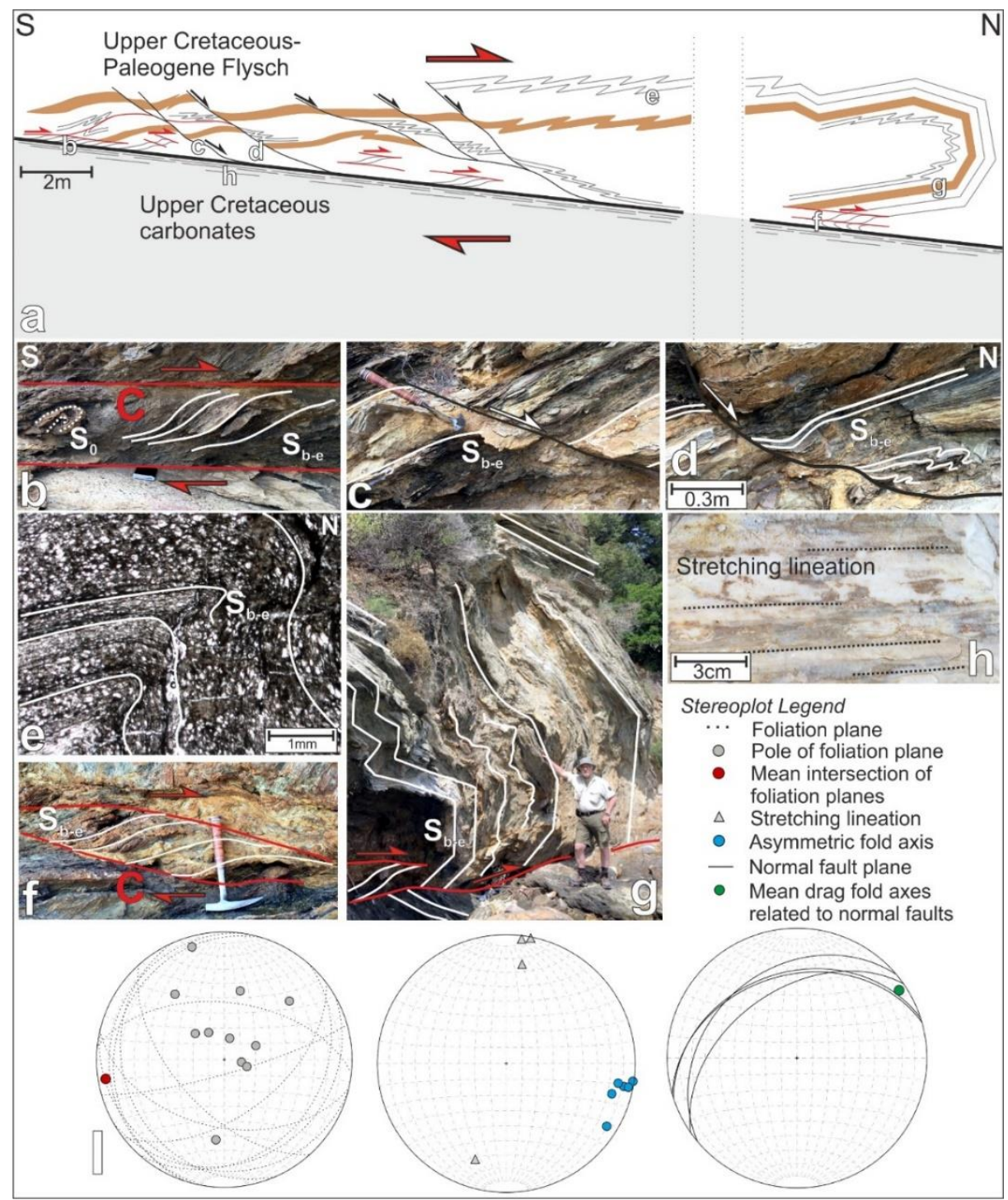

Figure 3.4. (a) Top-NNE extensional shear zone at Location 5 activating the stratigraphic contact between the Upper Cretaceous carbonates in the footwall and the Upper Cretaceous-Paleogene Flysch in the hangingwall. Details of the shear zone are highlighted in the subfigures; (b) TopNNE semi-brittle shear bands at the contact of the two formations, notebook for scale; (c) NWdipping, low-angle normal fault, hammer for scale; (d) NW-dipping normal fault with semi-brittle asymmetric folds in the hangingwall; (e) Plain polarized microscope image of the sample from Location 5 showing a single tectonic foliation that is subparallel to the $S_{0}$ bedding. Sedimentary features such as the inverse grading of quartz grains are still visible. The asymmetric top-NNE fold also observed in the outcrop (Figure 3.3) did not develop an axial planar cleavage supporting the idea of semi-brittle to brittle flexural folding; (f) Ductile top-NNE shear band in the mylonitic contact zone, hammer for scale; (g) Recumbent box-fold in the hangingwall of the shear zone, Dimitrios for scale; (h) Strong stretching lineation in the footwall marble; (i) Stereographic projections of structural elements measured in the outcrop. 


\subsubsection{Key outcrops}

Location 5 (Skiathos town shear zone) at Skiathos city, provides an excellent section to study strain localization during $\mathrm{D}_{\mathrm{e}}$ deformation phase. The lower part of the outcrop consists of Upper Cretaceous calcite marbles, which are overlain by the Upper Cretaceous Paleogene flysch formation (Figure 3.4a). The contact is low-angle, on average dipping $\sim 10^{\circ}$ to the North. Close to the contact, the marbles exhibit a closely spaced, subhorizontal mylonitic foliation and an intensely developed stretching lineation trending NNE-SSW (Figures 3.4h and i). The flysch above is also well-foliated, and consists of quartz-rich, finegrained metasandstone intercalated with some mica-rich layers. Sericites define the foliation and also the NNE-SSW oriented stretching lineation. Both in the carbonates and the flysch, only one main tectonic foliation is found $\left(\mathrm{S}_{\mathrm{b}}-\mathrm{S}_{\mathrm{e}}\right.$ composite foliation) which is subparallel with the original $\mathrm{S}_{0}$ bedding. The flysch shows an intensely sheared fabric which is best developed close to the contact towards the carbonates. We identified two sets of C-type shear bands; one which rotates the foliation without cutting through the foliation planes, thus attesting to deformation by ductile creep (Figure 3.4f), and one which not only drags, but clearly cuts the foliation planes in a brittle manner associated with thin fault gouges or fine-grained breccias along the shear planes (Figure 3.4b). Both types of shear bands document the same top-NNE kinematics, providing evidence for perseverant kinematics of the shear zone under decreasing temperature conditions.

The flysch also shows a large number of asymmetric, close to tight folds, which have a consistent top-NNE vergence (Figures 3.4a, d, e, and g) and are not developed in the carbonates below. These folds do not have an axial planar cleavage, implying that metamorphic conditions at the stage of folding were probably not high enough to induce ductile creep in the quartz-rich layers (Figure 3.4e). Most of these small asymmetric folds are parasitic to a large, recumbent, box-type fold structure which probably formed by flexural slip along the foliation planes of the flysch (Figure 3.4g). The folds are cut by numerous small-scale normal faults that have $<1 \mathrm{~m}$ displacement (Figure 3.1a) and consistently dip towards the NNW (Figures 3.4a, c, and d). This represents a continuous record of northward displacement in the shear zone including stages of ductile shearing, semi-brittle shearing and folding, and normal faulting related to extensional exhumation of the rocks. The normal faults are moderately inclined $\left(30-40^{\circ}\right)$ suggesting that the rotation of the shear zone took place during or after its main activity. The shear zone clearly localized at the original stratigraphic contact between the carbonates and the flysch. The carbonates seem to accommodate large amount of ductile strain showing more intense stretching lineation and mylonitic foliation; while semi-brittle and brittle strain is more localized in the metaclastic flysch formation. Figure 3.3a shows that the normal faults do not cut through the contact between the marbles and the flysch, instead they join and reactivate the contact between the two formations which was previously sheared in a ductile manner. 


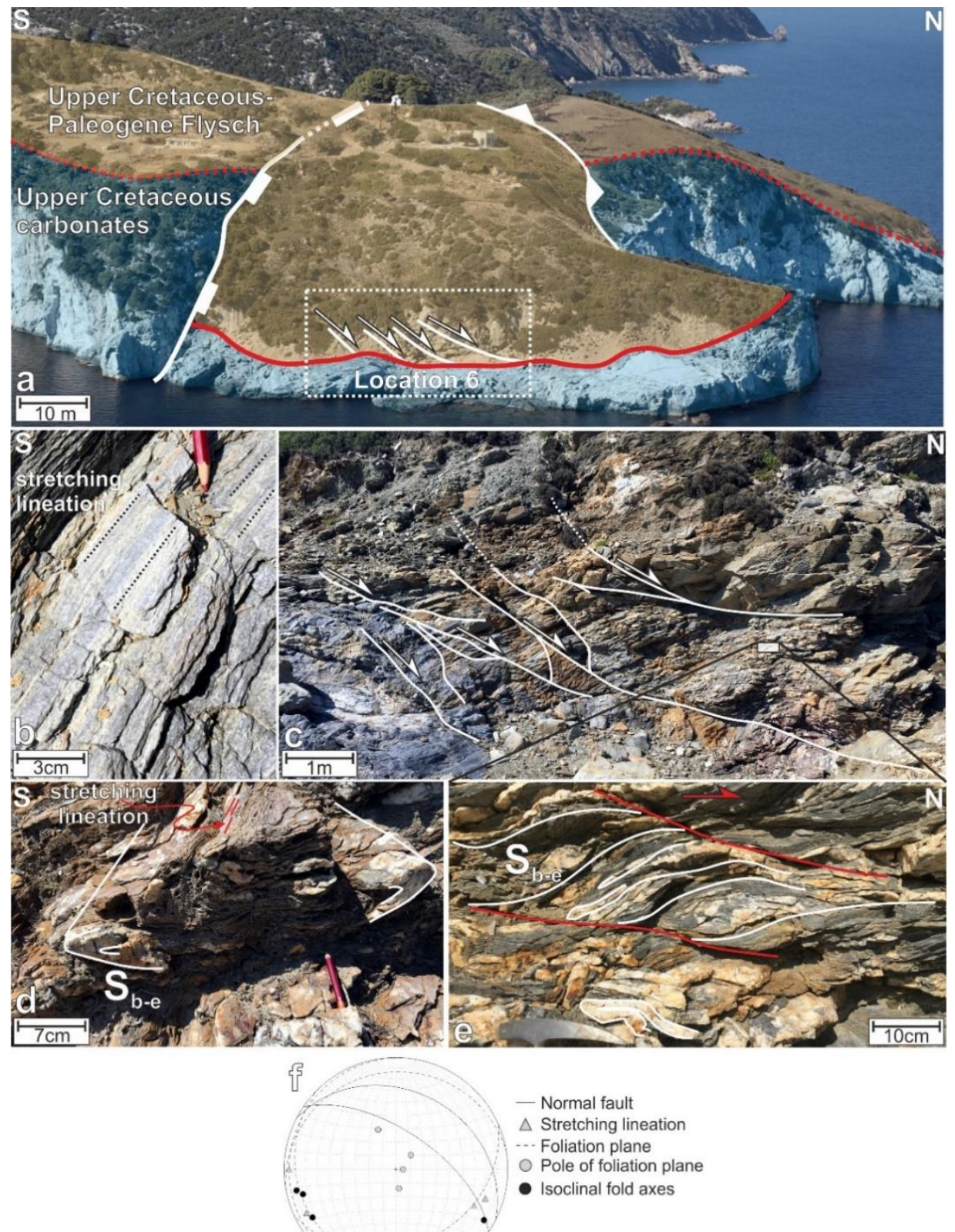

Figure 3.5. Top-NE to E extensional shear zone at Location 6 activating the stratigraphic contact between the Upper Cretaceous carbonates and the Upper Cretaceous-Paleogene Flysch. (a) Aerial view (photo from tripinview.com) of the shear zone and its surroundings; (b) Well-developed stretching lineation; (c) A network of flat, NE-dipping normal faults that link to the shear zone below; (d) Non-cylindrical (sheath) fold with fold axes subparallel with the stretching lineations; (e) Top-NE C-S type shear bands overprinting previously formed isoclinal folds in the shear zone; (f) Stereographic projections of structural elements measured in the outcrop. 
Location 6 on Skopelos (Figure 3.5) provides a section that is very similar to Location 5 on Skiathos; it also exhibits Upper Cretaceous carbonates overlain by the Upper Cretaceous - Paleogene flysch formation, with an intensely deformed stratigraphic contact in between (Figure 3.5). The Upper Cretaceous marble and the carbonate-rich layers of the flysch show a well-developed mylonitic foliation $\left(\mathrm{S}_{\mathrm{b}}-\mathrm{S}_{\mathrm{e}}\right.$ composite foliation) and stretching lineations (Figure 3.5b). The stretching lineations trend ESE-WNW to NE-SW (Figure 3.5f) and are associated with top-ESE to NE sense of shear evidenced by C-type shear bands (Figure 3.5e). Top-ESE to NE shear bands consistently overprint previously formed isoclinal folds (Figure $3.5 \mathrm{e}$ ), but are associated with the formation of non-cylindrical folds (sheath folds) trending subparallel with the stretching lineations (Figure 3.5d). The mylonitic foliation and the sheath folds are restricted to the shear zone which is 10-15 meters thick. The ductile shear structures have been overprinted by a series of NE-dipping normal faults that joined the main shear zone and reactivated it in a brittle manner (Figures 3.5a and c). Some of the normal faults are low-angle, probably attesting to the rotation of the shear zone, while some of them are close to the ideal $60^{\circ}$ probably related to a later, post-tilt phase of normal faulting (Figure 3.5a). Similarly, to Location 5, this outcrop provides an example for the progressive extensional exhumation of the rocks from ductile shearing to asymmetric normal faulting.

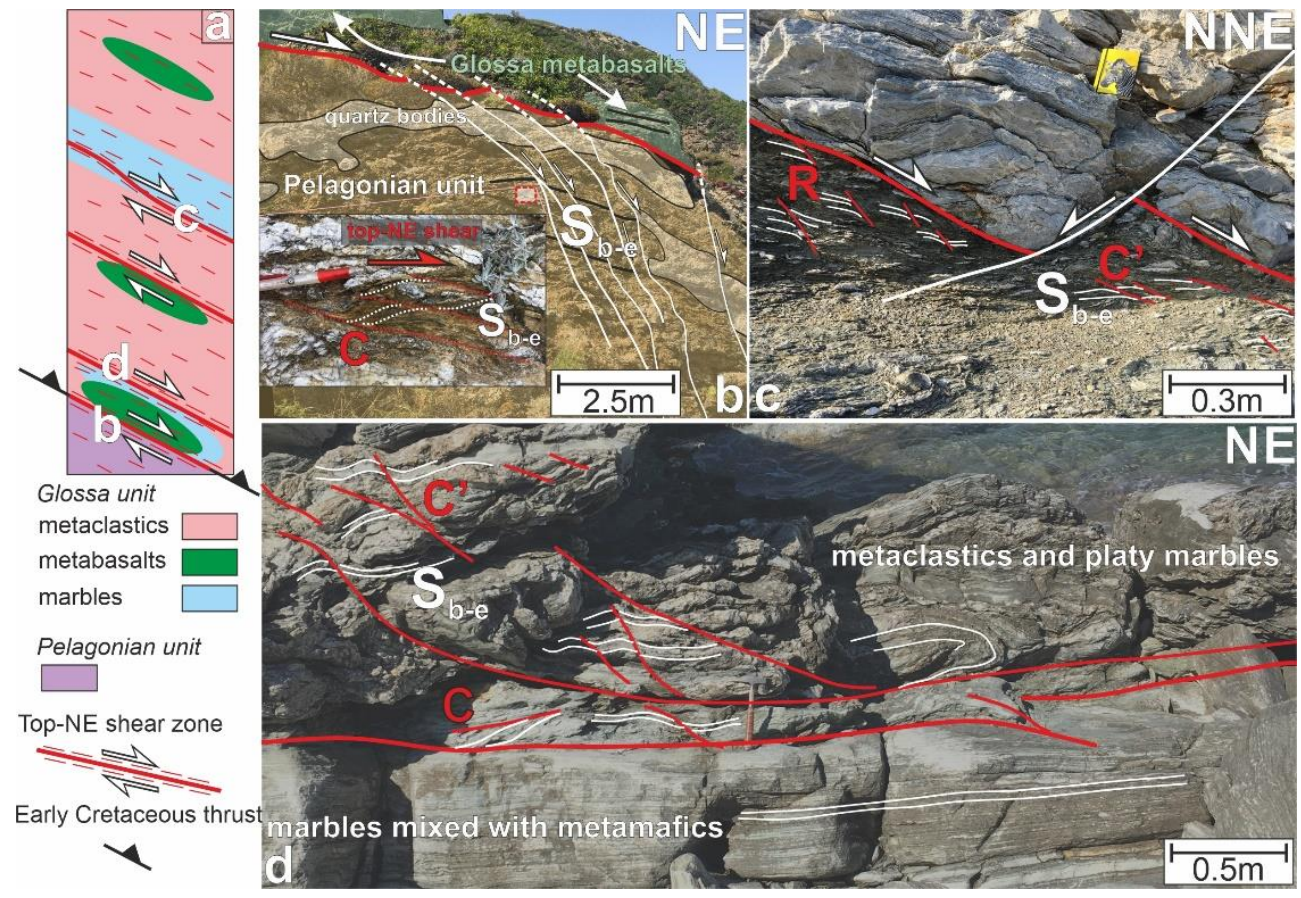

Figure 3.6. Extensional strain localization in the Glossa unit, on Skopelos; (a) Schematic tectonostratigraphic column of the Glossa unit, highlighting the position of extensional shear zones and key outcrops; (b) Extensional reactivation of the Early Cretaceous nappe contact between the Pelagonian and Glossa units by top-NE shearing and normal faulting, modified after Porkoláb et al. (2019b) (Location 7); (c) Top-NNE ductile to brittle extensional shear zone between the metaclastic and marble formations of the Glossa unit (Location 9); (d) top-NE shear zone between the mixed metabasalt-marble and the metaclastic formations of the Glossa unit (Location 8). 
The Glossa unit on Skopelos displays further examples of extensional strain localization (Figure 3.6). Figure 3.6a shows that the entire Glossa unit was affected by distributed topNE shearing, while localized top-NE shearing occurred along 1) the inherited Early Cretaceous nappe contact between the Pelagonian and the Glossa units (Figure 3.6b, Location 7, discussed in Porkoláb et al. (2019b)); 2); the contact between the marbles/metabasalts and the metaclastics (Figure 3.6d, Location 8); and 3) the contact between the metaclastic and marble formations (Figure 3.6c, Location 9). Location 7 is an outcrop of a 10-15 m thick shear zone separating the Pelagonian and Glossa units, displaying mylonitic foliation, NESW trending stretching lineations, top-NE C-type shear bands, and large amount of secondary quartz overgrowth near the main movement zone. The ductile shear zone shows a brittle overprint that does not precisely reactivate the ductile shear zone as a low-angle normal fault, but largely cuts through it with steeper normal faults (Figure 3.6b). Location 8 shows a topNE shear zone between the mixed marbles-metabasalts and the metaclastics of the Glossa unit (Figure 3.6d). The calcite-rich footwall rocks have an extremely fine mylonitic foliation and very well-developed NE-SW trending stretching lineations, while the quartz-rich hangingwall shows strong folding and quartz precipitation. Both $\mathrm{C}$ and $\mathrm{C}^{\prime}$-type shear bands were observed, the $\mathrm{C}^{\prime}$-types showing a transition from ductile (curving the foliation planes) to brittle (cutting the foliation planes) style of deformation. Location 9 displays a ductile to brittle shear zone separating the marbles and metaclastics of the Glossa unit (Figure 3.6c). Both rock types were strongly sheared and display intense NNE-SSW trending stretching lineations, associated with top-NE C'-type shear bands. The shear zone was reactivated as a brittle, low-angle normal fault as evidenced by cataclastic bands and local brecciaction of the metaclastic rocks. The C'-type ductile shear bands have the same orientation as the overprinting brittle Riedel-planes (Figure 3.6b). The foliation planes are cut by the main slip surface at the steeper fault segments, showing that the shear zone was not entirely layerparallel in the brittle stage. 

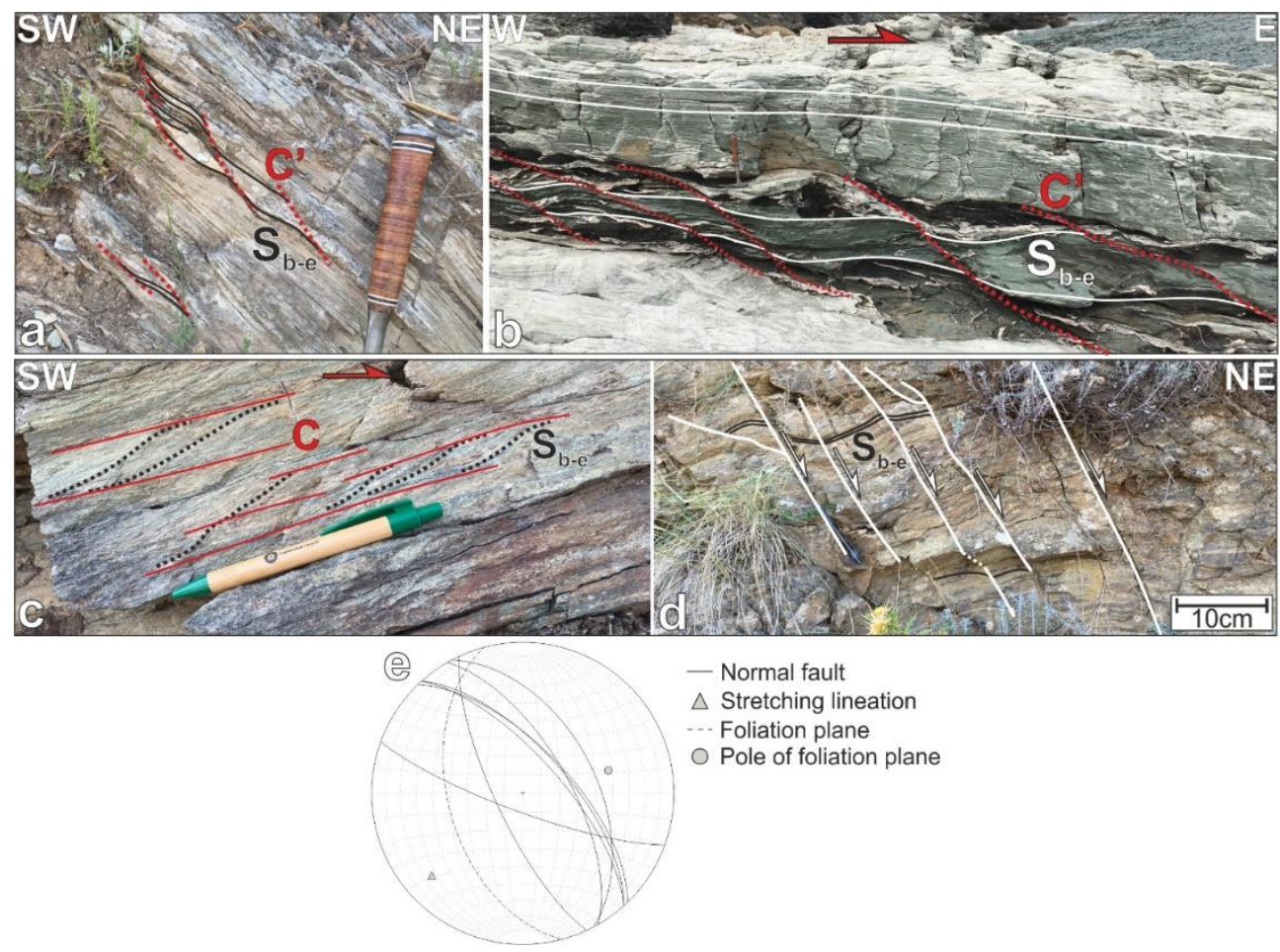

Figure 3.7. Examples of top-NE to E extensional shearing; (a) Top-NE C' shear bands at Location 10 showing the reactivation of a top-SW nappe contact that previously emplaced the Upper Cretaceous carbonates on top of the Upper Cretaceous-Paleogene Flysch; (b) Well-developed topE C' shear bands in the mafic metavolcanics in contact with marbles of the Glossa unit at Location 14. The dark green color of the metavolcanic rock is related to strong chloritization; (c) Top-NE $\mathrm{C}$-S shear bands in the metavolcanics of the Glossa unit at Location 12. The green bands in the rock are heavily chloritized; (d) top-NE normal faults in the same outcrop (Location 12) showing to continuity of tectonic transport through the cooling (exhumation) of the rocks; (e) Stereographic projections of structural elements measured at Location 12.

Locations 10 and 11 on Skiathos are located just above the top-SW ductile thrust that emplaced the Upper Cretaceous carbonates on the of the Upper Cretaceous - Paleogene flysch (Figure 3.1a). The outcrops exhibit a shear zone at the base of the marbles with a mylonitic foliation, NE-SW trending stretching lineations, and $\mathrm{SW}$-verging $\mathrm{S}_{0}-\mathrm{S}_{\mathrm{b}}$ relations, confirming that we find here the southward continuation of the shear zone at Location 1 (Figure 3.2). However, both Locations 10 and 11 show the dominance of opposite, top-NE shear sense indicators within the marble mylonites (Figure 3.7a). This implies, that top-NE shearing localized at the pre-existing top-SW shear zone, which was consequently reactivated in an opposite sense. 

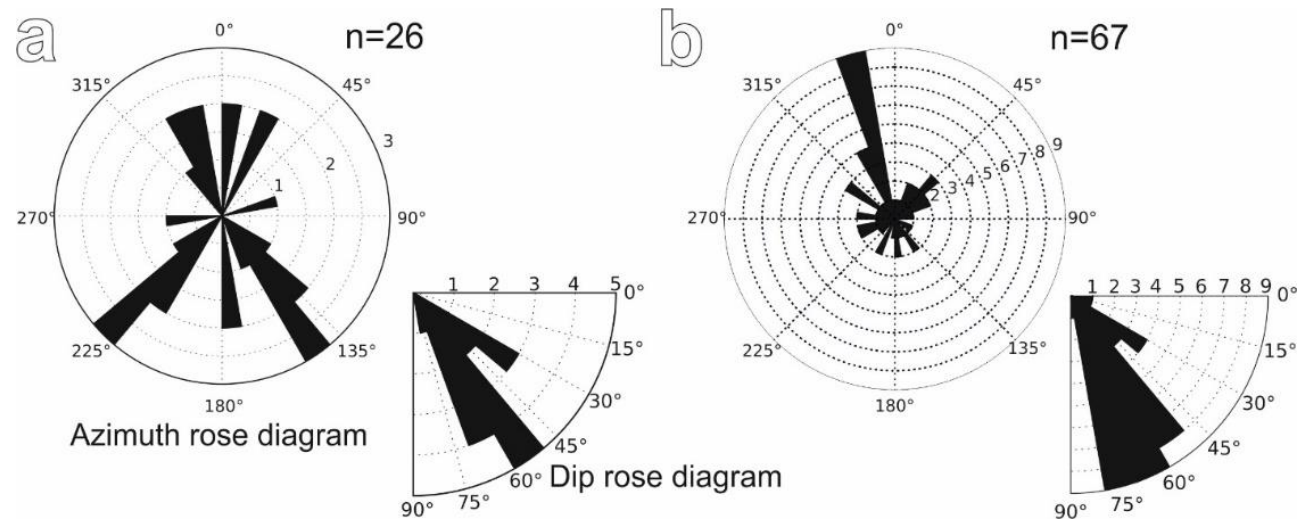

Figure 3.8. Azimuth and dip rose diagram of small-scale (up to several meters of displacement) normal faults measured (a) on Skiathos; and (b) on Skopelos.

\section{$3.4{ }^{40} \mathrm{Ar} /{ }^{39} \mathrm{Ar}$ dating of key shear zones}

We performed ${ }^{40} \mathrm{Ar} /{ }^{39} \mathrm{Ar}$ dating of white micas from two key shear zones at Location 1 and Location 5 (Figures 3.2 and 3.4, respectively) in order to constrain the timing of shear zone activity. It has been demonstrated on the island of Skopelos that resetting of the white mica Ar-system in the greenschist facies rocks of the Northern Sporades was achieved by deformation-induced crystallization of the foliation rather than thermally activated diffusion, thus the produced ages can be treated as time constraints for the deformation events (Porkoláb et al., 2019b).

In case of Location 1, we sampled the marble mylonites which constitute the shear zone between the Upper Cretaceous carbonates and the Flysch formation below (Figure 3.2). The marble consists of $>95 \%$ calcite, but contains minor amount of fine-grained white micas (sericite) (Figure 3.9a) which were separated in the grain size range of 100-250 $\mu \mathrm{m}$ for the dating, using a Faul vibrating table.

In case of Location 5 (Figure 3.4), we sampled the flysch formation which contained sufficient amount of sericite along the foliation planes (Figure 3.9b). The individual sericite crystals were too small to be separated, so we used ground mass separates $(250-500 \mu \mathrm{m})$ following the methodology of Pascual et al. (2013) and Porkoláb et al. (2019b).

The samples were packed in aluminium foil packages and stacked in an aluminium tube that was irradiated for 18 hours in the CLICIT facility of the Oregon State University TRIGA Reactor. For both irradiations the neutron flux was monitored by standard bracketing with the DRA sanidine standard with an age of $25.52 \pm 0.08 \mathrm{Ma}$, modified from Wijbrans et al. (1995) to be consistent with Kuiper et al. (2008). The step heating experiments were carried out in the Vrije University Amsterdam argon geochronology laboratory with $25 \mathrm{~W} \mathrm{CO}_{2}$ laser heating samples loaded on Cu-trays. The sample holder was connected to a three-stage extraction line and a quadrupole mass spectrometer (Schneider et al., 2009). Data was reduced in ArArCalc 2.50 (Koppers, 2002). Procedure blanks were monitored and diluted air shots were measured in the sequence to track mass discrimination. 


\subsubsection{Activity of the Kastro shear zone (Location 1): ${ }^{40} \mathrm{Ar} /{ }^{39} \mathrm{Ar}$ age spectra}

The dated sample from the Kastro shear zone (Location 1) was taken from the marble mylonites that contain $\sim 5 \%$ white micas. The thin section displays evidences for deformation by dislocation creep such as sutured grain boundaries, shape preferred orientation, and undulatory extinction (Figure 3.9a). The dynamically recrystallized calcite crystals went through grain size reduction during mylonitization as shown by the dominance of $\sim 100 \mu \mathrm{m}$ grain size and minor amount of remaining larger grains. Figure 3.9c shows the age spectra of the white micas separated from the sample. The majority of the heating steps define a dominant $\sim 55 \mathrm{Ma}$ age, while the three early steps show a staircase shape going down to 35 $40 \mathrm{Ma}$ (Figure 3.9c). Since the resetting of the Ar-system was achieved by deformationinduced crystallization of the white micas during the development of the foliation, we can interpret the $\sim 55 \mathrm{Ma}$ resetting as the main fabric forming event in the shear zone, which was related to the top-SW ductile thrusting. The three-younger steps in the staircase either suggest an overprinting event around 35-40 Ma, or alternatively gradual Ar-loss between $55 \mathrm{Ma}$ and 35-40 Ma. From a structural geological point of view, continuous deformation and thus foliation development for 20 Myrs is unlikely, therefore we suggest that the 35-40 Ma represents reactivation of the top SW shear zone, which has partially reset the Ar-system of the white micas. This view is in line with our field observations, which show top-NE normal sense reactivation of the shear zone (Figure 3.7a).
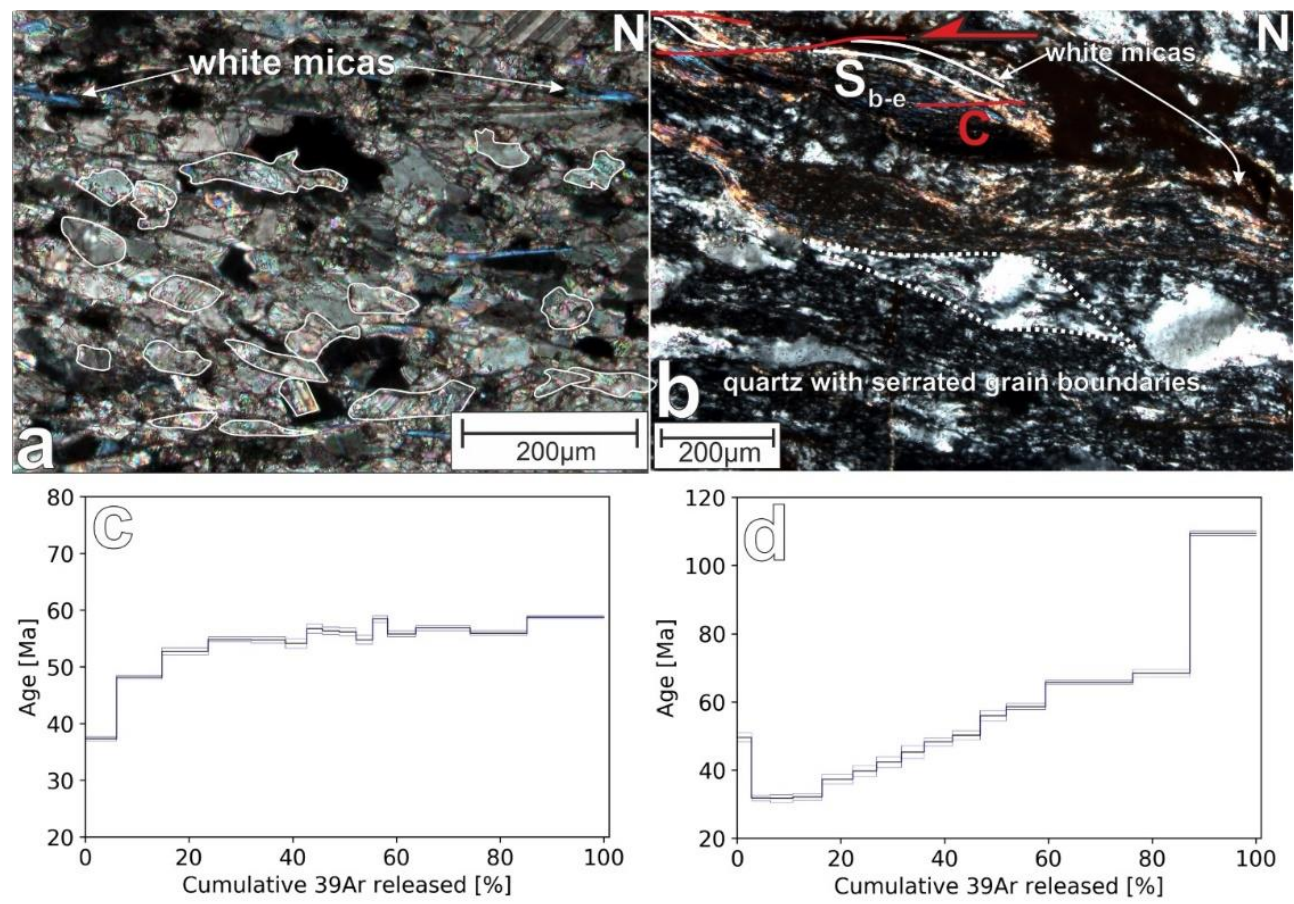

Figure 3.9. Results of ${ }^{40} \mathrm{Ar} /{ }^{39} \mathrm{Ar}$ step heating experiments and microstructural characterization of the dated samples. For locations see Figure 1; (a) Cross polarized image of the sample from Location 1 showing sutured grain boundaries in calcite attesting to deformation by dislocation 
creep and the presence of white mica flakes that were separated for dating; (b) Cross polarized image of the sample from Location 5. The sample largely consists of dynamically recrystallized quartz $(\sim 90 \%)$ and fine-grained white mica crystals. The top-SSW shear criteria presumably attesting to the tectonic burial of the rocks was not observed in the outcrop, which only exhibits top-NNE shear criteria related to extension (Figure 3.4); (c) Age spectra of the sample from Location 1. (d) Age spectra of the sample from Location 5. The horizontal axes show the cumulative ${ }^{39} \mathrm{Ar}$ released during the step heating, while vertical axes show the age of Ar-loss.

\subsubsection{Activity of the Skiathos town shear zone: ${ }^{40} \mathrm{Ar} /{ }^{39} \mathrm{Ar}$ age spectra}

Figure 3.9d shows the age spectra of the ground mass separates from the UpperCretaceous - Paleogene flysch at Location 5 (Skiathos town, Figure 3.4). The spectra reveal multiple elements of the history of white micas in the sample. The last heating step yielded an age of $\sim 110 \mathrm{Ma}$, the previous four steps are in between 55 and $65 \mathrm{Ma}$, while the last 9 steps define a prominent staircase-shaped spectra ranging from 50 to $30 \mathrm{Ma}$. The last heating step yielding the oldest age clearly shows that detrital white micas are still present in the flysch, which has also been reported from Skopelos (Porkoláb et al., 2019b). The presence of this detrital age confirms that the micas have not been reset by thermal diffusion under greenschist facies conditions, and that not all white micas are reset when the tectonic foliation developed in the rock. The previous four heating steps show ages between 55 and $65 \mathrm{Ma}$, probably attesting to the same burial-related fabric-forming event that is more dominant in the sample from the Kastro shear zone. This interpretation is supported by microstructural analysis of the dated sample: Figure 3.9b shows that our sample preserves inherited structures that were presumably related to burial and associated top-SW shearing and foliationdevelopment, which was not observed in the outcrop (Figure 3.4). The 55-65 Ma steps are preceded by 9 steps defining a staircase-pattern, which ranges from $\sim 50 \mathrm{Ma}$ to 30-35 Ma defining a similar young overprinting event as in case of Location 1, yet it seems to be more significant in this sample. The strong overprint is in very good agreement with our observations regarding the top-NNE extensional shearing at Location 5 which gradually shifted to normal faulting (Figure 3.4). We suggest that the rocks at Location 5 first developed a tectonic foliation during the top-SW burial of the rocks around 55-60 Ma, which was strongly overprinted by top-NE shearing around 30-35 Ma during the extensional exhumation of the rocks.

\subsection{Discussion}

\subsubsection{Implications for the nappe structure of the Northern Sporades}

Our field observations led to a substantial revision regarding the tectono-stratigraphy of Skiathos and Skopelos. In case of Skopelos, we use the published map of Porkoláb et al. (2019b), but we highlight different structural elements that have not been discussed before, and present a new, smaller scale cross section (Figure 3.10b). 
In earlier studies, no structures related to post-Cretaceous shortening have been reported from Skiathos. Our field results, maps and cross sections (Figures 3.1 and 3.9), however, show that both Skiathos and Skopelos exhibit several reverse-sense shear zones, which produce repetitions in the upper parts of the stratigraphy. These repetitions were either not observed, or incorrectly interpreted as stratigraphic contacts by previous works on Skiathos (Ferentinos, 1973; Heinitz and Richter-Heinitz, 1983) or Skopelos. On Skiathos, these are 1) the top-SW shear zones outcropping at Locations 1 and 8 that emplaces the Upper Cretaceous carbonates on top of the flysch; and 2) the top-SSW shear zone outcropping at Location 3 and 4 that emplaces the Upper Triassic carbonates on top of the Upper Cretaceous carbonates or the flysch formation. On Skopelos, these are 1) the N-dipping thrust outcropping at Location 2 that emplaces the Upper Cretaceous carbonates on top of the flysch; and 2) a Sdipping backthrust at Location 10 that similarly emplaces the Upper Cretaceous carbonates on top of the flysch (Figures 3.1 and 3.9).
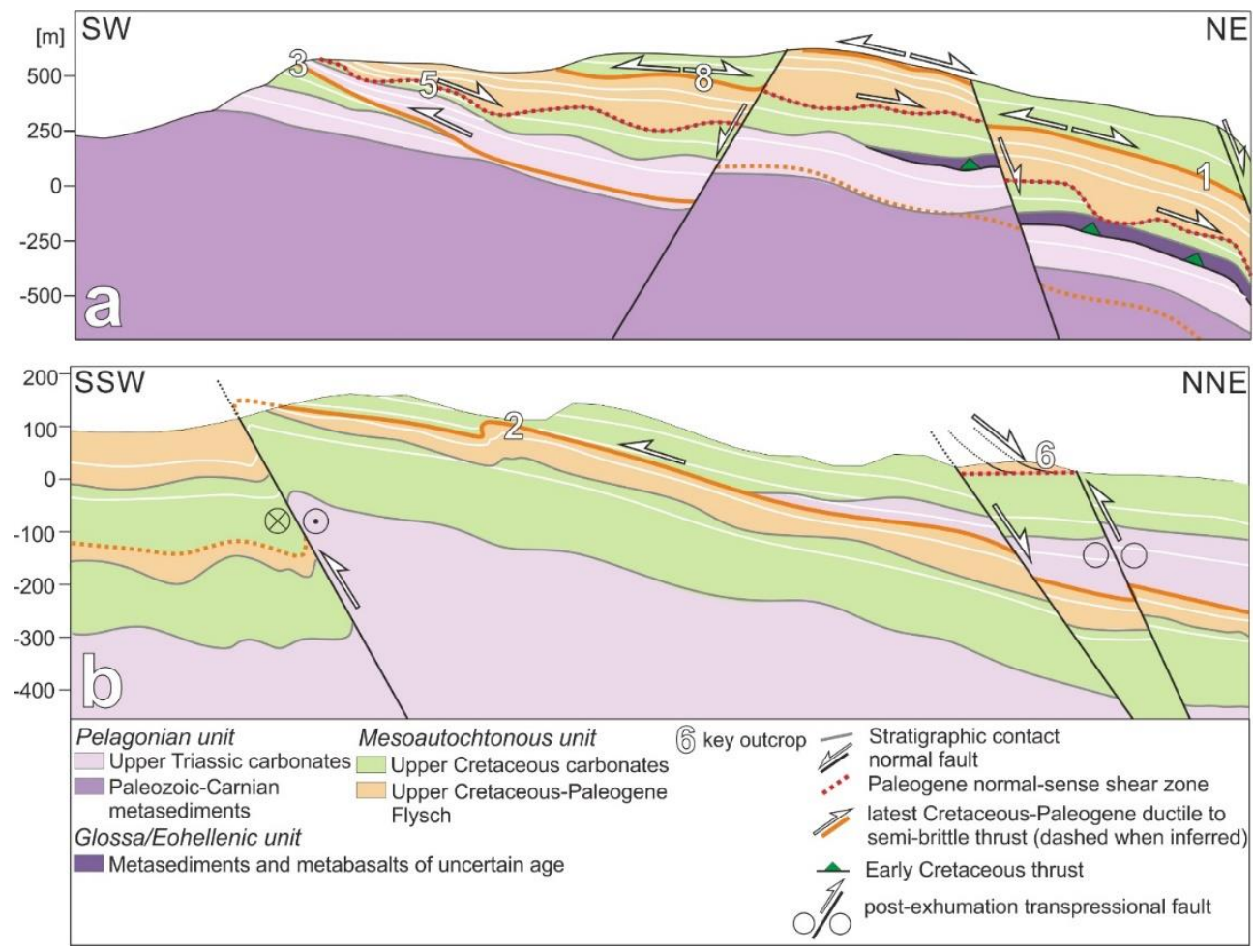

Figure 3.10. Cross sections from (a) Skiathos; and (b) Skopelos. For map-view traces of the cross sections see Figure 3.1 .

These structures are all low-angle $\left(<30^{\circ}\right)$ and produced a tectonic transport that was subparallel with the $S_{0}$ bedding in the formations (Figure 3.10). Most of the ductile strain was localized in the relatively weak parts of the carbonate formations (Upper Triassic and Upper Cretaceous) that show a well-developed mylonitic foliation and stretching lineation as opposed to the surrounding massive carbonates (partly dolomites, partly massive calcite marbles) and siliciclastic formations. The flat-lying, top-SW shear zones produced smallscale nappes (several 100 meters thick) which seem to be rooted in a relatively shallow part 
of the Pelagonian strata: no hangingwall unit older than Upper Triassic was observed along these thrusts (Figure 3.10). The estimated timing of top-SW thrusting on Skiathos $(\sim 55 \mathrm{Ma}$ in this study) is consistent with the findings of Porkoláb et al. (2019b) reporting dominantly 55-65 Ma ${ }^{40} \mathrm{Ar} /{ }^{39} \mathrm{Ar}$ white mica fabric ages from Skopelos. Our discovery of the $\mathrm{D}_{\mathrm{b}}$ shear zones shows that post-Cretaceous shortening was much more pronounced on Skiathos than previously thought (Ferentinos, 1973; Heinitz and Richter-Heinitz, 1983).

\subsubsection{Geometry of upper crustal shortening: the role of stratigraphy}

The Aegean consists of exhumed upper crustal thrust sheets derived from the Adria microcontinent, while most of the lower crust and lithospheric mantle subducted into the asthenosphere (Ricou et al., 1998; van Hinsbergen et al., 2005). Decoupling of the upper crust from the rest of the continental lithosphere in numerical models is explained by a major weak zone at the base of the upper crust, defined by the compositional difference between the upper crust and the lower crust (e.g. Vogt et al., 2017). Such models may explain the formation of an upper crustal nappe stack, but lack resolution to account for strain localization in multi-layer systems within the upper crust. In this section, we discuss the intraupper crustal strain localization during the collision of Pelagonia with Rhodopia based on our key observations.

Our observations suggest that weak calcite layers have played a key role in localizing top-SW shearing following the onset of shortening (Figures 3.2 and 3.3). We have identified two main decoupling levels that determine the geometry of thrusting; namely the relatively weak parts of the Upper Cretaceous and the Upper Triassic shallow-water carbonates (Figures 3.2 and 3.3). In order to understand the stratigraphic control on the thrusting geometries, we discuss the rheology of the initial, pre-shortening ( $70 \mathrm{Ma})$ lithological succession of the Pelagonian upper crust (Figures 3.11a and b). Our simplified lithological succession consists of (from top to bottom): 1) Upper Cretaceous - Paleogene flysch which is predominantly quartz-rich sandstone; 2) Upper Cretaceous shallow water carbonates containing both massive and layered (weaker) limestones; 3) Ophiolites (mafics and ultramafics) that are partially or completely eroded depending on the exact location, subophiolitic metasediments, siliciclastic sediments of the Albian transgressive sequence; 4) Jurassic and Upper Triassic shallow water carbonates containing both massive, dolomitic, and weaker, layered calcite limestones; 5) Pre-Middle Triassic clastic metasediments and continental crystalline basement rocks.

The observed strain gradients (strain localization in the weak carbonates) suggest that certain parts of the shallow-water carbonates are significantly weaker under low-grade metamorphic conditions than the quartz-rich formations like the Upper Cretaceous Paleogene flysch. Calcite flow laws based on the assumption that dislocation climb mechanism controls the ductile creep of calcite do not predict such strength differences compared to quartzite flow laws (e.g. Koch et al., 1989; Ranalli, 1995; Schmid et al., 1980). In contrary, a flow law based on the dislocation cross slip mechanism of calcite marbles by De Bresser (2002) predicts creep behavior for calcite layers already at the depth of several kilometers (depending on the geotherm and stress state), resulting in higher predicted strain rates (i.e. strain localization) for calcite layers then for wet quartzites. 
We show a simplified strength profile of the top $15 \mathrm{~km}$ of the crust considering two calcite layers within the Upper Cretaceous and Upper Triassic carbonate formations which behave according to the cross slip flow law (De Bresser, 2002). All other layers are assumed to behave according to a wet quartzite rheology (Koch et al., 1989) (Figure 3.11b). Our calculations show, that the two calcite layers are substantially weaker than the surrounding rocks due to the difference in deformation mechanism (ductile creep for the calcite, brittle failure for the wet quartzite). Consequently, the localization of deformation in the calcite layers is predicted for the shallow upper crust, showing a good fit with our observations (Figures 3.2 and 3.3). Ductile creep in the wet quartzite initiates at the depth of 9-10 km, and around the depth of 13-14 km, the strength of the calcite layers and the wet quartzite become comparable, predicting a more distributed style of deformation. On the scale of the crust, the base of the upper crust (between 15 and $20 \mathrm{~km}$ ) is still predicted to be the most important weak layer being responsible for the decoupling of the upper crust from the rest of the lithosphere. However, the two weak calcite layers define significant, shallow decoupling horizons, where intra-upper crustal shortening would localize (Figure 3.11a and b). The three main ductile shear zones are connected by ductile (below $\sim 10 \mathrm{~km}$ ) or brittle (above $\sim 10 \mathrm{~km}$ ) thrust segments, resulting in a ductile flat-brittle ramp type of thrusting geometry (Figure 3.11a). 

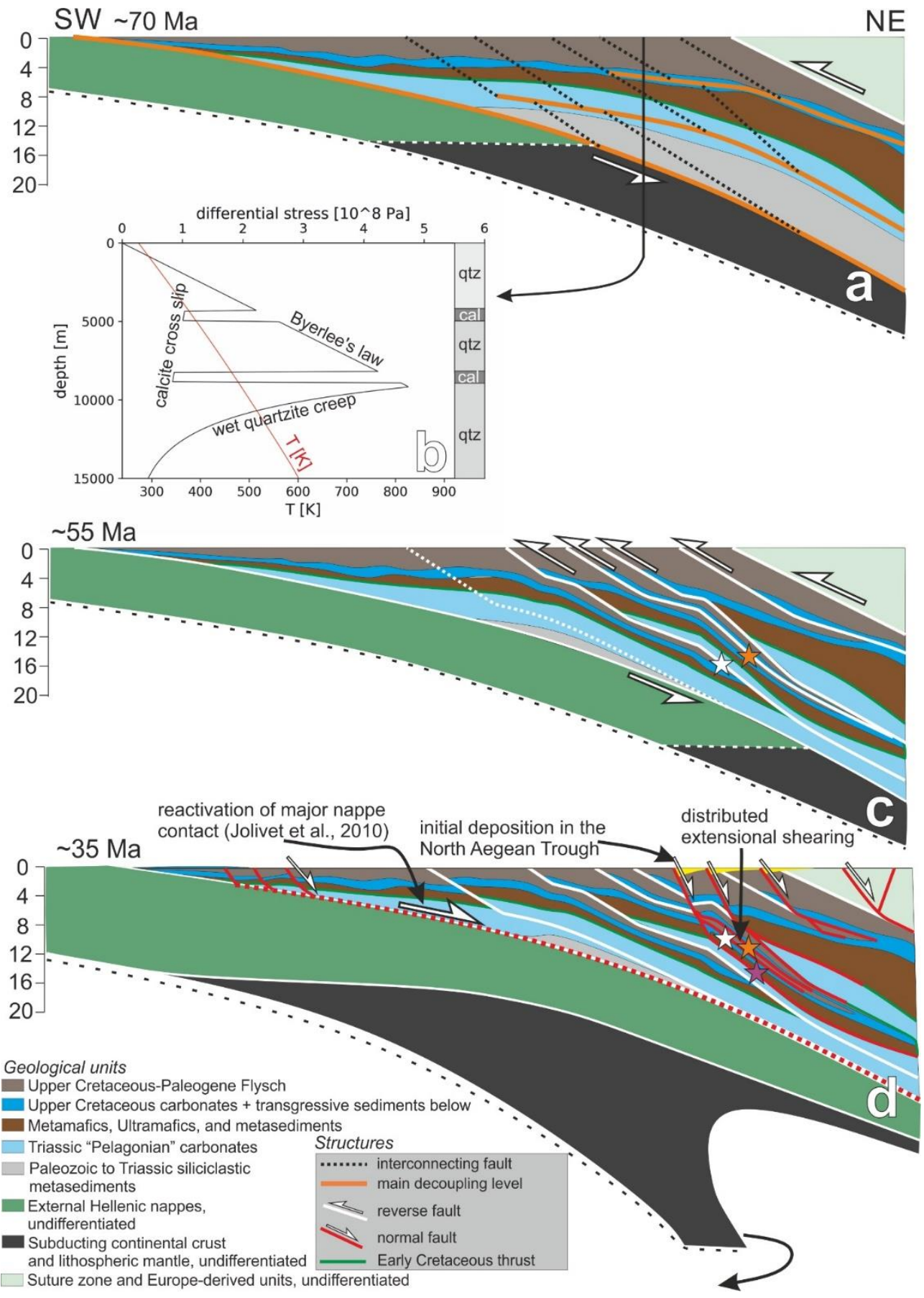

Figure 3.11. Schematic evolutionary model of the Pelagonian upper crust from $\sim 70$ to $\sim 35 \mathrm{Ma}$; (a) Simplified lithological model of the Pelagonian upper crust prior to nappe stacking. The thicknesses of the formations correspond to regional values taken from the literature. The stratigraphic thickness of the flysch formation is difficult to estimate as it is eroded and structurally 
disrupted to thin slices (e.g. Clift and Robertson, 1989; Sharp and Robertson, 2006; present study), but when it is preserved, it can reach a thickness of a few kilometers (Toljić et al., 2018); (b) Strength profile calculated for the uppermost $15 \mathrm{~km}$ of the crust assuming an average continental geotherm (corresponding to $65 \mathrm{~mW} / \mathrm{m}^{\wedge} 2$ surface heat flow) and a strain rate of $10^{\wedge}-141 / \mathrm{s}$. Two calcite layers are taken into account that follow the calcite cross slip flow law by de De Bresser (2002). The rest of the upper crust is approximated with a wet quartzite rheology (Koch et al., 1989); (c) Top-SW nappe stacking at 55 Ma. The equivalents of our key observations regarding the emplacement of Upper Cretaceous and Upper Triassic carbonates on top of younger formations (Locations 1, 2 and 3, 4) are highlighted by orange and white stars, respectively; (d) Top-NE extensional inversion of the nappe stack at $~ 35$ Ma. The equivalents of our key observations regarding the localized shearing at stratigraphic contacts (Figures 3.4 and 3.5), the reactivation of top-SW marble mylonite shear zones (Figure 3.7a), and the reactivation of an Early Cretaceous nappe contact are highlighted by orange, white, and purple stars, respectively.

Figure $3.11 \mathrm{~b}$ shows our schematic interpretation of intra-upper crustal thrusting at $\sim 55$ Ma. By that time, all the formations reached greenschist facies metamorphic conditions (Porkoláb et al., 2019b, this study). Imbrication of the upper crust took place by top-SW thrusting, subparallel to the $S_{0}$ bedding in the rocks, coeval to the development of the pervasive $S_{b}$ tectonic foliation. The presence of two shallow decoupling levels resulted in the formation of thin nappes that are rooted in the upper parts of the original stratigraphy (Figure 3.11b).

Our timing constraints with respect to top-SW thrusting and related fabric forming ( $55 \mathrm{Ma}$ ) are consistent with geochronological results from the surrounding regions (Lips et al., 1998; Lips et al., 1999; Most, 2003; Porkoláb et al., 2019b; Schermer et al., 1990) and confirm large-scale models that the Pelagonian upper crust accreted to the Eurasian upper plate during early Paleogene times by top-SW thrusting (Brun and Faccenna, 2008; Jolivet and Brun, 2010). Following its accretion, the Pelagonian thrust sheet was emplaced on top of the more external Hellenic units (Figure $3.11 \mathrm{~b}$ and c), namely the Pindos, GavrovoTripolitza, and Ionian upper crustal thrust sheets, which also accreted to the upper plate oneby one, between $\sim 45$ and $~ 30$ Ma (Jolivet and Brun, 2010; Schmid et al., 2019; van Hinsbergen et al., 2005). The accretion of crustal units to the upper plate triggered the southward retreat of the subduction trench, which has been driving extension in the Aegean since 40 Ma (Bonev et al., 2013; Brun and Faccenna, 2008; Brun et al., 2016; Brun and Sokoutis, 2007; Rohrmeier et al., 2013). The exhumation of the metamorphosed continental nappes is generally attributed to extension, and the role of erosion in the unroofing of the nappe stack is yet to be explored. The proper estimation of the time distribution and the amount of eroded material from the Northern Sporades is presently hindered by the poor quality of available seismic lines and the lack of borehole data in the North Aegean Trough (Beniest et al., 2016).

\subsubsection{Strain localization during extensional exhumation}

\subsubsection{Geometry and evolution of extensional shear zones}

The top-SW nappe stacking was overprinted by opposite sense, on average top-NE, greenschist facies shearing, which we relate to the extension of the Pelagonian nappe stack. The tectonic foliation developed during the burial of the rocks $(\sim 55 \mathrm{Ma})$ was deformed and 
partially recrystallized during extension ( 30 - 35 Ma according to the overprinting of the white mica Ar-system). We note that no separate extensional foliation cross-cutting $\mathrm{S}_{\mathrm{b}}$ was observed. Most outcrops on both islands display small increments of layer -parallel $\sim$ topNE shearing (Figure 3.7c) implying that the entire thickness of the strata was affected by distributed ductile shearing. Additionally, several sections show localized, ductile to brittle, top-NE shearing on the scale of the islands (Figures 3.4, 3.5, and 3.6). These extensional shear zones are parallel/subparallel with the pre-existing $\mathrm{S}_{0}-\mathrm{S}_{\mathrm{b}}$ foliation, up to 15 meters thick, and do not produce an observable difference in the metamorphic grade between the footwall and hangingwall units, attesting to relatively minor displacements (probably up to a few hundreds of meters). Our observations suggest that both stratigraphic and tectonic (thrust) contacts were oriented favorably (dipping to N-NE) to enhance extensional reactivation of these structures (Figure 3.11d). Top-SW imbrication developed a dense network of N-NE dipping weak zones (thrust or sheared stratigraphic contacts) which resulted in a characteristic, distributed extensional shearing pattern using multiple small shear zones rather than localization along a single, major detachment (Figure 3.11d). These shear zones show evidences of progressive deformation starting under ductile and continuing under brittle conditions (Figures 3.4, 3.5, and 3.6). We interpret these observations as the gradual extensional exhumation of the rocks starting with top-NE ductile shearing, continuing with transitional shearing, semi-brittle folding, and finishing with normal faulting. Alternatively, the embrittlement of the shear zones due to increasing fluid pressure during mylonitization and mineralization could be envisaged to explain the switch from ductile to brittle shearing (Selverstone et al., 2012). Normal faults that developed in the same rock volume following the localized ductile shearing in the rocks typically appear in asymmetric sets dipping the same way as the shear zones (Figure 3.4 and 3.5). The observation that most of the normal faults join the shear zones rather than crosscutting them (Figure 3.4 and 5) suggests that the shear zones remained important decoupling horizons also under brittle conditions and have been reactivated as low-angle normal faults. The majority of the normal faults are rather lowangle $\left(30-40^{\circ}\right)$, implying that rotation took place during the exhumation of the rocks similar to large-scale detachment systems in nature (e.g. Lister and Davis, 1989), or in analogue models (Brun et al., 1994). Alternatively, the formation of low-angle normal faults could be explained by an inclined rather than vertical sigma 1 orientation (Axen, 2019). The key characteristics (relatively small, no linkage with each other, showing transition from ductile to brittle extensional shearing) of the extensional shear zones of Skiathos and Skopelos are identical to the minidetachments described from the proximity of the Whipple detachment in California (Axen, 2019; Axen and Selverstone, 1994). In the case of the Whipple detachment, the linkage of minidetachments at the brittle-ductile transition zone (BDTZ) lead to the formation of the main structure which eventually accommodated most of the displacement (Axen, 2019). Many other detachments over the globe show such strain localization at the BTDZ (e.g. Arca et al., 2010; Martínez-Martínez and Azañón, 1997; Reynolds and Lister, 1990; Selverstone, 1988), and its mechanics has also been shown plausible by numerical and analogue experiments (Brun et al., 1994; Tirel et al., 2008). A key condition for detachment formation at the BDTZ thus is the existence of a favored decoupling level where the normal faults that cut the brittle upper crust are rooted (Figure 3.12a). In contrast, Skiathos and Skopelos display multiple decoupling levels defined by the network of N-NE-dipping heterogeneities (Figure 3.11d) which resulted in multiple similarly sized (5-15m thick) shear zones, but no linkages between them. A similar case of distributed extension has been 
reported from the Apennines, where the W-dipping thrusts of the nappe stack are partially reactivated in extension as low-angle normal faults. These structures do not link up with each other to form a major detachment, and individually accommodate minor amounts of extension (Keller et al., 1994). Figure 3.12c shows our simple model of such a distributed style of extension which is accommodated largely by layer-parallel shearing along multiple horizons (minidetachments), and does not result in the formation of a major detachment due to the lack of linkages between the small shear zones. We note however, that the amount of extension applied to the system is certainly crucial. Substantially more extension applied to the nappe stack of the Northern Sporades would most likely have resulted in the linkage of the shear zones to form a major detachment, and a related metamorphic core complex.

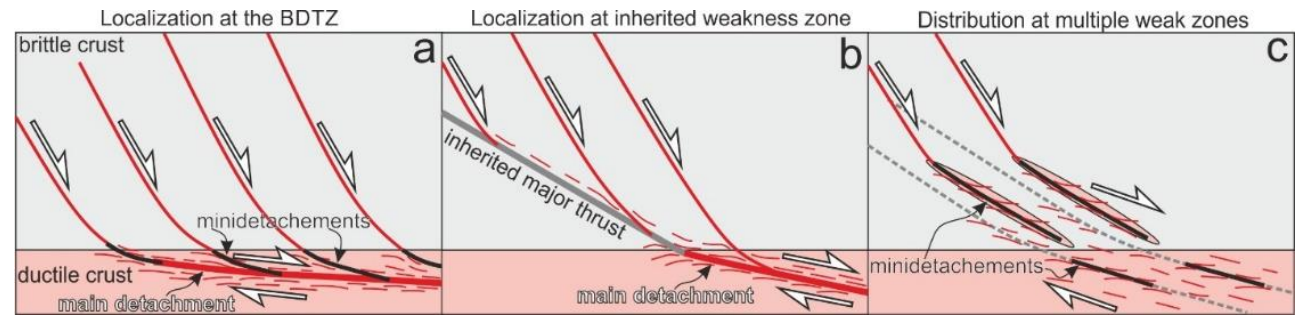

Figure 3.12. End-members of extensional strain localization; (a) Localization of a detachment at the Brittle-Ductile Transition Zone (BDTZ); (b) Localization of a detachment at a major inherited weakness zone (e.g. inherited nappe contact or suture zone); (c) Distribution of extensional shearing over multiple weak zones (inherited faults with dashed grey lines), with no major detachment localized due to the lack of linkage between the shear zones.

\subsubsection{The role of structural inheritance in extensional strain localization: the Aegean example}

The formation of detachments may also occur by the extensional reactivation of major weakness zones such as nappe contacts; examples have been described from Corsica (Daniel et al., 1996), from the Himalaya (Patel et al., 1993), and from the Aegean (Jolivet et al., 2010). Identically to detachment localization at the BDTZ, the normal faults that cut the upper brittle layer of the crust are rooted in a single detachment which controls the exhumation of the footwall (Figures 12a and b). Such highly localized extensional patterns have been described from the more external Hellenic thrust sheets outcropping on the northern Cyclades (e.g. Jolivet et al., 2010; Lister et al., 1984) and from Rhodopia (e.g. Brun and Sokoutis, 2007; Sokoutis et al., 1993), standing in contrast with the distributed extensional style of Skiathos and Skopelos.

The Cycladic metamorphic units were exhumed by a top-NE detachment or detachment system, resulting in discrete jumps in the metamorphic grade between footwall and hangingwall units, and the exhumation of higher-grade metamorphic rocks compared to the Northern Sporades. It has been suggested that the localization of the North Cycladic Detachment was controlled by the major top-SW nappe contact separating the formations of the Pelagonian (Internal Hellenic) thrust sheet which did not witness Eocene HP-LT metamorphism from the Pindos/Cycladic blueschist (External Hellenic) units which followed an Eocene HP-LT and Oligocene-Miocene HT-LP metamorphic path (Jolivet et al., 2010 and references therein) (Figure 3.11). In contrast, the internal shortening of the Pelagonian thrust sheet - as observed on Skiathos and Skopelos - was characterized by a more distributed 
thrusting pattern - due to the multiple weak zones in the upper crust - accommodating the shortening on multiple smaller thrusts, hence not producing one prominent rheological weakness zone in the crust. Thus, the difference in the magnitude and localization of postorogenic, top-NE, extensional shearing between the northern Cyclades and the Northern Sporades may originate in the different distribution of the preceding shortening.

In case of Southern Rhodopia, a highly localized, opposite-sense, top-SW extensional detachment (Kerdylion detachment) controlled the exhumation of a metamorphic core complex consisting largely of amphibolite facies gneisses, marbles, micaschists, and migmatites (Brun and Sokoutis, 2007; Brun and Sokoutis, 2018; Dinter and Royden, 1993; Sokoutis et al., 1993). The reason for the opposite sense of the Kerdylion detachment is yet to be thoroughly investigated, but a possible explanation has been proposed by Jolivet et al. (2018). The authors argue, that back-arc basins opened by slab rollback (such as the Aegean) are subjected to large-scale simple shear induced by the faster trenchward flow of the mantle below the weak crust of the upper plate. The shearing is becoming more effective as the core complexes evolve due to the increasing area affected by the basal drag, and might result in a temporal switch between dominant detachment kinematics; from top-SW (Rhodopia) to topNE (Cyclades) in case of the Aegean (Jolivet et al., 2018). In addition to this, we suggest, that the opposite sense of the Kerdylion detachment might also be influenced by structural inheritance. In contrast with the Adria-derived tectonic units, Rhodopia was subjected to a change in subduction polarity, from SW-dipping during the Jurassic and Early Cretaceous to NE-dipping during the Late Cretaceous - Paleogene (e.g. Jahn-Awe et al., 2010). The former SW-dipping subduction resulted in the formation of major top-NE thrusts which produced a penetrative SW-dipping fabric in the rocks (Bonev and Stampfli, 2003; Okay et al., 2001; Schmid et al., 2019). These structures might have controlled strain localization during the Eocene extension and localized the main detachment along a SW-dipping pre-existing weak zone.

\subsubsection{Late-stage brittle extension}

The initial geometry of the normal faulting linked to the flat-lying decoupling horizons was characterized by asymmetric, predominantly northerly-dipping fault sets which often have been rotated (Figures 3.4, 3.5, and 3.10d). However, following the further exhumation of the rocks, more symmetric (both northerly and southerly dipping) normal faults formed, most of which have not been substantially rotated based on their dip angle (Figure 3.8), and accommodated map-scale extensional deformation (Figure 3.1 and 3.9). Widespread normal faulting and related development of Neogene basins in the Aegean has been attributed to the acceleration of slab-rollback from $\sim 15 \mathrm{Ma}$, possibly induced by the tearing of the Hellenic slab (Brun et al., 2016; Brun and Sokoutis, 2010). We suggest that the majority of non-tilted, symmetric normal fault sets on Skiathos and Skopelos are related to this accelerated phase of extension during the Neogene. This idea is supported by the thick (possibly up to $6 \mathrm{~km}$ ) Neogene sediments deposited in the North Aegean trough north of Skopelos (Beniest et al., 2016; Jongsma, 1975; Mascle and Martin, 1990) (Figure 3.1). The small-scale faults (up to a several meters of displacements) have a highly varying orientation with no clear evidence for overprinting relations between the differently oriented sets, thus making a paleostress analysis of the faults pointless (Figure 3.8). The two main sets (NW-SE trending and NE-SW 
trending) of small-scale normal faults imply perpendicular extensional directions, corresponding to trench-perpendicular $(\sim \mathrm{NE}-\mathrm{SW})$ and trench-parallel $(\sim \mathrm{NW}-\mathrm{SW})$ directions in reference to the Hellenic subduction zone. It has been suggested that trench-perpendicular extension driven by trench retreat and trench-parallel extension driven by the opposite-sense rotation of the eastern and western Aegean are of comparable magnitude (van Hinsbergen and Schmid, 2012). Trench-parallel extension resulted in the enhanced thinning of the South Aegean nappe stack, however, its effect must have been much less in the North Aegean where oroclinal bending was not as pronounced (Hinsbergen and Schmid, 2012). Our maps and cross sections show that the majority of the map-scale faults (minimum a few tens of meters of displacement) are oriented roughly NW-SE on Skiathos and Skopelos, supporting the idea that trench-perpendicular extension has been predominant in the area of the Northern Sporades (Figures 3.1 and 3.9). However, the presence of numerous NE-SW trending smallscale faults (Figure 3.8) suggests that the second and third principal stress axes $\left(\sigma_{2}\right.$ and $\left.\sigma_{3}\right)$ had roughly the same magnitude for a period of time, allowing the switch from NE-SW to $\mathrm{NW}$-SE oriented $\sigma_{3}$.

\subsection{Concluding remarks}

We presented a case study on how strain is distributed within a major upper crustal nappe (Pelagonian thrust sheet), from the initial stages of tectonic burial to the extensional exhumation of the formations. Detailed structural analysis on two islands (Skiathos and Skopelos) supplemented by ${ }^{40} \mathrm{Ar} /{ }^{39} \mathrm{Ar}$ dating of key shear zones led to the following conclusions:

- The Northern Sporades display several thin thrust sheets consisting of shallow upper crustal formations. Our structural mapping resulted in the definition of two thrust contacts on Skiathos that are reported here for the first time.

- Thrusting predominantly took place by ductile top-SW shearing under low-grade metamorphic conditions, localized in weak calcite marble layers within the Upper Cretaceous and Upper Triassic carbonates at $\sim 55 \mathrm{Ma}$. We show that the rheological heterogeneity defined by the pre-shortening stratigraphy is key in understanding strain localization during the tectonic burial of the continental upper crust. The multiple decoupling levels in the upper crust of the Northern Sporades resulted in distributed top-SW thrusting, i.e. the formation of thin, small-scale nappes.

- Our kinematic and timing constraints support model implications suggesting that extension initiated following the Early Paleogene accretion of the Pelagonian upper crust to Eurasia (e.g. Brun and Faccenna, 2008).

- Extensional inversion of the nappe stack initiated by opposite-sense, generally top$\mathrm{NE}$, ductile shearing, which localized at inherited heterogeneities such as reversesense shear zones and stratigraphic contacts at $\sim 35 \mathrm{Ma}$. The dense network of northerly-dipping, inherited weakness zones resulted in a highly distributed pattern of ductile extensional deformation (layer-parallel shearing). The shear zones did not link up with each other and consequently no major extensional detachment formed. We argue that the contrasting distribution and kinematics of post-orogenic extension 
in the different regions of the Aegean (Cyclades, Northern Sporades, and Southern Rhodopia) was influenced by structural inheritance.

- Ductile top-NE shearing was gradually replaced by semi-brittle shearing and normal faulting attesting to the extensional exhumation of the rocks. Dominantly northerly dipping normal faulting linked to the northerly dipping decoupling levels was later replaced by more symmetric normal faulting. The orientation of normal faults suggests variable extensional directions (mainly trench-perpendicular and trenchparallel), with the predominance of NE-SW, trench-perpendicular extension. 


\section{Chapter 4. Two Cenozoic burial phases revealed by structural and geochronological data from the Nevado-Filábride complex (Sierra de los Filábres, SE-Spain) ${ }^{3}$}

3 This chapter is based on Porkoláb, K., Matenco, L., Hupkes, J., Willingshofer E., Wijbrans J., van Hinsbergen, D., in preparation for Tectonics 


\subsection{Introduction}

The Betic-Rif orogen in the Western Mediterranean region (Figure 4.1a) has been instrumental for understanding the role of slab dynamics and continental subductionexhumation processes (Booth-Rea et al., 2015; Platt et al., 2003a; Spakman et al., 2018). In a simplified form, the orogen consists of an Eocene and younger metamorphosed nappe stack, derived mainly from subducted continental crust (the internal Betics or the Alboran zone), which was emplaced during Miocene times over an imbricated, mostly non-metamorphosed sedimentary cover of the Iberian and North African margins (the external Betic and external Rif zones), and the Atlantic oceanic crust in the Gulf of Cadiz (e.g., Azañón et al., 1998; Balanyá and García-Dueñas, 1987; Martínez Martínez, 1986; Platt et al., 2003a; van Hinsbergen et al., 2020). Tectonic reconstructions and seismic tomographic images have shown that the burial and exhumation history was associated with $400-800 \mathrm{~km}$ of subduction, even though the Africa-Iberia absolute plate convergence was less than $100 \mathrm{~km}$ (Booth-Rea et al., 2007; Faccenna et al., 2004; van Hinsbergen et al., 2014). The excess in the amount of subduction is interpreted to result from slab roll-back that included a significant amount of westward slab retreat, more or less orthogonal to the N-S convergence direction between Africa and Iberia (Lonergan and White, 1997; Rosenbaum et al., 2002). In this general framework, the original geometry of the subduction zone (dipping N-NW versus SE) and the exact amount of slab roll-back are still debated, which has resulted in a number of different paleogeographic and geodynamic scenarios (e.g. Faccenna et al., 2004; Handy et al., 2010; Pedrera et al., 2020; Romagny et al., 2020; van Hinsbergen et al., 2020; van Hinsbergen et al., 2014; Vergés and Fernàndez, 2012). This debate is ultimately rooted in different interpretations of the timing and direction of nappe stacking, metamorphism and exhumation of the units in the internal Betic orogen, and particularly in the Nevado-Filábride Complex (NFC, Figure 4.1b). The NFC is a composite unit that contains both oceanic and continental rocks metamorphosed at eclogite-facies conditions, which has yielded both Eocene and Miocene geochronological ages, interpreted as prograde metamorphism (Augier et al., 2005a; Kirchner et al., 2016; Li and Massonne, 2018; Monié et al., 1991; Platt et al., 2006; SánchezVizcaíno et al., 2001). The NFC contains a (ultra)mafic unit, where the presence of often metamorphosed Jurassic gabbros, dolerites, (pillow)basalts, pelagic sediments, and peridotites implies a dominantly ocean-derived character (Puga et al., 2011; Puga et al., 1999). However, a number of observations such as the presence of depleted and serpentinized mantle rocks, Al-rich xenolits in the metabasites, mafic dykes intruded into continental formations, and the analysis of detrital $\mathrm{U}-\mathrm{Pb}$ zircon populations suggest that the rock succession might have originated from a hyper-extended continental margin setting (GomezPugnaire and Munoz, 1991; Jabaloy-Sánchez et al., 2021; Laborda-López et al., 2020; Morten et al., 1987), similar to the the West Iberian Atlantic margin (e.g. Reston et al., 2007).

The NFC is truncated at the top by a major extensional detachment (Martínez-Martínez et al., 2002; Platt and Vissers, 1980) that separates it from the continental Alpujárride Complex (AC). The continental-derived AC was buried to high pressure-low temperature (HP-LT) metamorphic conditions in Eocene times (Azañón, 1997; Bessière, 2019; BoothRea et al., 2002; Goffé et al., 1989; Monié et al., 1994; Platt et al., 2005) below rock units of the structurally highest, Maláguide Complex (MC). The AC and MC were interpreted to be derived from the $\mathrm{AlKaPeCa}$ microcontinental fragment that existed within the Alpine Tethys 
Ocean, together with formations exposed in the Kabylides units of Northern Africa and units exposed on Sicily and Calabria (Bouillin et al., 1986; Handy et al., 2010; van Hinsbergen et al., 2014).

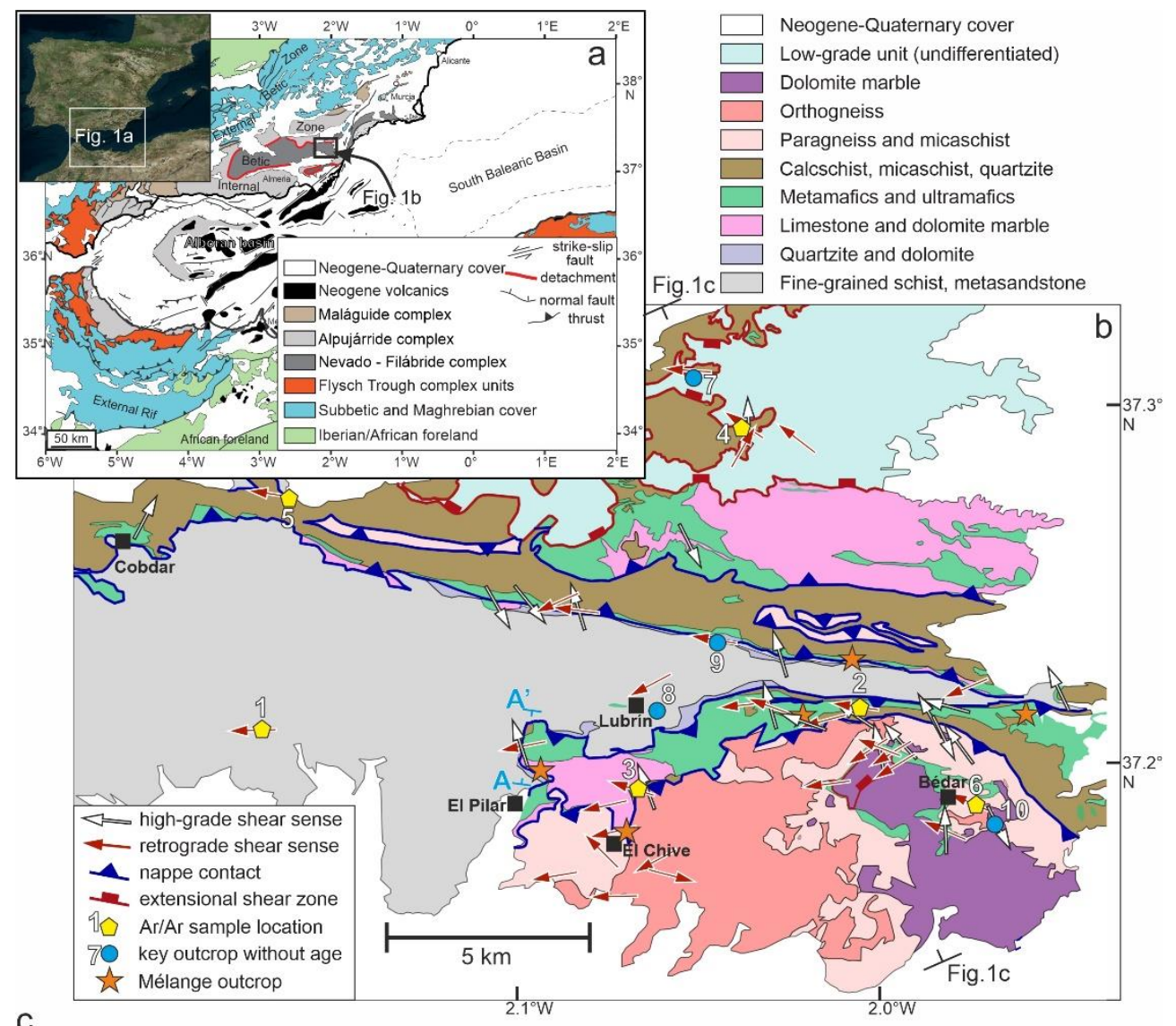

C

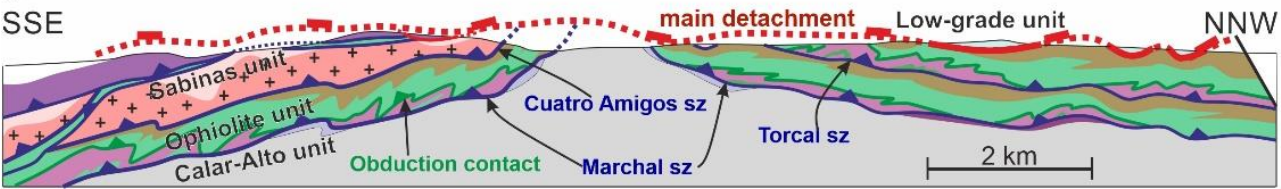

Figure 4.1. (a) Large-scale geological map of the Gibraltar arc(modified after Comas et al., 1999). (b) Geological map of the study area (eastern Sierra de los Filábres), modified after Garcia Monzón et al. (1974), containing shear sense indicators, the locations of dating samples and the location of other key outcrops. A-A' is the location of the cross section in Figure 4.5a. (c) NNWSSE cross section through the study area highlighting the major geological structures (sz=shear zone).

Two contrasting interpretations have been offered for the timing of burial in the NFC, based on different (or differently interpreted) geochronological data. One interpretation is based on Paleogene geochronological data derived from the continental units of the NFC in terms of ${ }^{40} \mathrm{Ar} /{ }^{39} \mathrm{Ar}$ ages on amphiboles (Monié et al., 1991) and white micas (Augier et al., 2005a; de Jong et al., 1992), and U-Th-Pb ages on monazites (Li and Massonne, 2018), 
interpreted as HP-LT metamorphism in the continental NFC starting at $48 \mathrm{Ma}$, simultaneously with the burial of the structurally higher AC. This interpretation assumes Paleogene burial, while other Miocene geochronological ages are thought to reflect a stage of slow exhumation, resulting in a correlation of the NFC with the same paleogeographic continental unit as the $\mathrm{AC}$ and $\mathrm{MC}$ (AlKaPeCa unit, Bouillin et al., 1986). This interpretation is difficult to reconcile with the limited amount of Eocene convergence inferred by paleogeographic reconstructions ( $<100 \mathrm{~km}$, e.g. van Hinsbergen et al., 2020), which appears to be insufficient for the burial of the entire oceanic to continental NFC domain.

Another interpretation is based on U-Pb zircon dating of mafic eclogites (SánchezVizcaíno et al., 2001), Lu-Hf garnet dating of oceanic and continental rocks (Platt et al., 2006), and ${ }^{87} \mathrm{Rb} /{ }^{86} \mathrm{Sr}$ multi-mineral dating of one mafic eclogite and two metapelite samples (Kirchner et al., 2016), which yielded Miocene ages ( 20-12 Ma). These ages are interpreted to reflect prograde burial metamorphism, which implies that the NFC belonged to the Iberian continental margin that subducted below Alboran domain (AC and $\mathrm{MC}$ ) during Miocene times. These studies however do not account for the Paleogene geochronological results and consider those datasets unreliable therefore, discard the interpretation of Paleogene NFC burial (e.g. Behr and Platt, 2012; Platt et al., 2006). Furthermore, a precise structural differentiation between nappe contacts and extensional detachments is still unclear across the NFC (e.g., Martínez-Martínez et al., 2002). The current NFC and AC definition in the key area exposing the (ultra)mafic unit (eastern Sierra de los Filábres) follows the contrast in metamorphic grade, which was created by the tectonic omission along the extensional detachment after nappe stacking (Martínez-Martínez and Azañón, 1997; Martínez-Martínez et al., 2002; Platt and Vissers, 1980). Such a definition is difficult to be directly used for distinguishing paleogeographic domains stacked in a subduction zone.

Here we aim to reconcile the tectonic architecture of the internal Betics in the key area of the eastern Sierra de los Filábres, by focusing in particular on the juxtaposition of continental and ocean-derived units and the geometry, kinematics, and timing of main shear zones. We complement the extensive database of previous studies by kinematic mapping and structural analyses, together with single grain fusion ${ }^{40} \mathrm{Ar} /{ }^{39} \mathrm{Ar}$ dating of white micas in structurally strategic outcrops. We re-evaluate the kinematics and timing of tectonic burial in the NFC, allowing us to revisit the structural definition of tectonic units, constrain the paleogeographical and kinematic reconstructions of the Alboran region, and provide new insights on the mechanics of Cenozoic burial-exhumation processes.

\subsection{Geological setting}

The internal Betic nappe stack consists of three major nappe complexes, from top to bottom the low-grade to non-metamorphic Maláguide (MC), the low-grade to high-grade Alpujárride (AC), and the high-grade Nevado-Filábride (NFC) (e.g., Azañón, 1997; Balanyá and García-Dueñas, 1987; Booth-Rea et al., 2002; Martínez Martínez, 1984; Platt et al., 2003b; van Hinsbergen et al., 2014; Vissers, 2012). The NFC is located in the core of an elongated, E-W oriented metamorphic dome, while the AC and the MC makes up the flanks of this structure (Figure 4.1a). In our study area of the eastern Sierra de los Filábres (Figure 4.1b), only the AC and the NFC are exposed. 
The AC consists of a Paleozoic succession of metapelites (phyllites) and quartzites, overlain by a Triassic succession of meta-clastic sediments, evaporites (gypsum) and (meta)carbonates, as well as including mafic intrusive bodies (Garcia Monzón et al., 1974). The AC is exposed on the northern flank of the eastern Sierra de los Filábres and has been separated from the NFC based on its (locally) substantially lower metamorphic grade (e.g. Booth-Rea et al., 2002; Garcia Monzón et al., 1974; Martínez-Martínez et al., 2002). The base of the AC is defined by a zone of retrograde mylonites and cataclasites that represent a major extensional detachment known as the Betic Movement Zone, separating the AC in the hanging-wall from the NFC in the footwall across a significant tectonic omission (MartínezMartínez et al., 2002; Platt et al., 1984; Platt and Vissers, 1980). The AC in the eastern Betics reached low-temperature blueschist facies metamorphic conditions with a peak temperature of $350-450{ }^{\circ} \mathrm{C}$ (Booth-Rea et al., 2002) in Eocene times, interpreted as subduction-related metamorphism (Bessière, 2019; Goffé et al., 1989; Monié et al., 1994; Platt et al., 2005). Subduction of the AC was followed by its extensional exhumation and a related HT-LP metamorphic overprint during the early Miocene (Azañón et al., 1998; Booth-Rea et al., 2004; García-Dueñas et al., 1992; Lonergan and Johnson, 2002; Platt et al., 2003b; Rossetti et al., 2005).

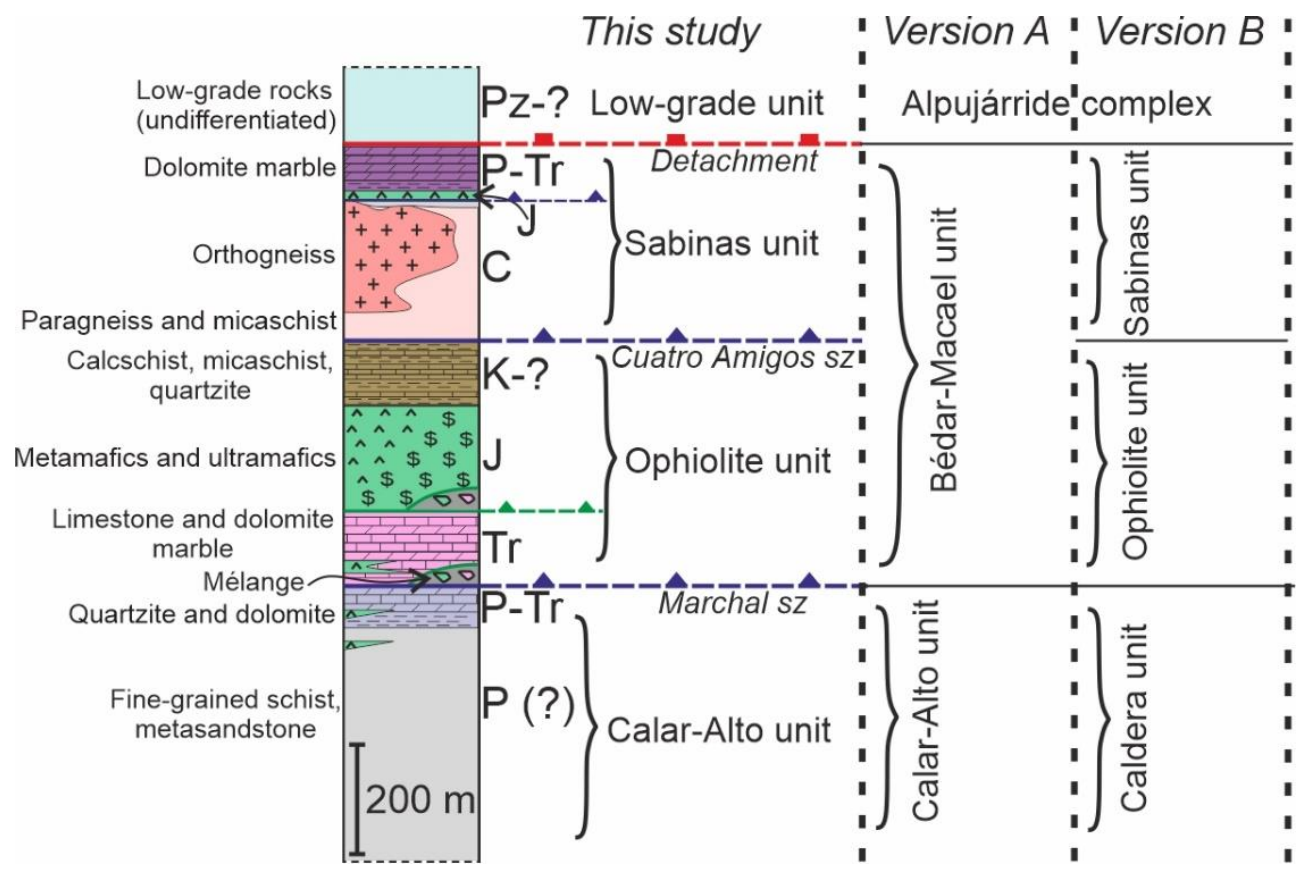

Figure 4.2. Tectono-stratigraphic column of the study area with the results of this study and the tectonic subdivisions used by previous studies, Version A (e.g. Booth-Rea et al., 2015; GarcíaDueñas et al., 1988; Martínez-Martínez et al., 2002; Martínez Martínez, 1984; Platt et al., 2006), and Version B (Puga et al., 2002; Puga et al., 2017; Puga et al., 2011).

The NFC is defined as all rock units situated in the footwall of the Betic Movement Zone and is commonly subdivided into three tectonic units characterized by upward increasing metamorphic grade across the separating thrusts, while upward decreasing metamorphic grade within a single unit (Figure 4.2, Augier et al., 2005a; Augier et al., 2005b; 
Booth-Rea et al., 2015; Martínez-Martínez et al., 2002; Martínez Martínez, 1986). In the eastern Sierra de los Filábres (Figure 4.1b), the Calar-Alto unit, equivalent of the Caldera unit (Puga et al., 2002), is composed of a thick (up to $1500 \mathrm{~m}$ ), likely Permian succession of dark to light, pelitic schists (Tahal formation), overlain by Permian to Triassic metaconglomerates, quartzites, and carbonates, intercalated with small lenses of meta-mafic rocks (meta-dolerites) (Figures 4.1b, c, Figure 4.2, Garcia Monzón et al., 1974; Martínez Martínez, 1984; Martínez Martínez, 1986). This unit is structurally overlain by the previously described (ultra)mafic unit thought to contain the remnants of a former oceanic lithosphere and those of a hyper-extended continental passive margin (Gomez-Pugnaire and Munoz, 1991; Laborda-López et al., 2020; Puga, 2005; Puga et al., 2011). The (ultra)mafic succession contains (meta)gabbros, mantle peridotites of spinel-lherzolite composition and other, more or less depleted mantle rocks, such as cumulus troctolites, and are crosscut by doleritic and plagiogranitic dykes, which are best exposed in the area of Cobdar (Figure 4.1b, Puga, 2005). It furthermore contains (meta)basalts showing preserved pillow and flow structures (Puga, 2005). The igneous age of the mafic rocks was determined by U-Pb dating of metagabbros and metadolerites yielding Early Jurassic ages (185 \pm 3 Ma, Puga et al., 2011). The (ultra)mafic succession is overlain by metasediments (quartzites, micaschists, and calcschists), interpreted to be part of a pelagic sequence that formed on the ocean floor possibly during Cretaceous time (Puga et al., 2011; Tendero et al., 1993).

The structural separation of the (ultra)mafic unit is debated. One group of studies include these rocks in a Bédar-Macael unit that also contains Paleozoic and Mesozoic continental formations (version A on Figure 4.2, e.g. Augier et al., 2005a; Martínez-Martínez et al., 2002; Martínez Martínez, 1984; Platt et al., 2006). The observation of small mafic bodies and dykes intruding the continental formations of the Calar-Alto unit and the overlying carbonates (Booth-Rea et al., 2009a, b; Morten et al., 1987), U-Pb age populations of detrital zircons (Jabaloy-Sánchez et al., 2018; Jabaloy-Sánchez et al., 2021), and stratigraphic studies (Ortí et al., 2017; Simon, 1987) support the common origin of the mixed continental-oceanic NFC succession, which might have belonged to a former hyper-extended continental margin (Booth-Rea et al., 2015; Gomez-Pugnaire and Munoz, 1991; LabordaLópez et al., 2020). This interpretation does not account for the observations that the (ultra)mafic rock sequence contains all the elements of a typical (although dismembered and metamorphosed) oceanic lithosphere sheet, favored by the second group of studies defining a separate Ophiolite unit (version B on Figure 4.2, Puga et al., 2002; Puga et al., 2011). Regardless the structural definition, the (ultra)mafic unit is interpreted by geophysical studies to have a significantly larger thickness $(4-9 \mathrm{~km})$ at depth, beneath Sierra de los Filábres (Pedrera et al., 2009).

An interesting structural situation is the contact between the (ultra)mafic unit and the overlaying sequence, best exposed in the area of Bédar (Figure 4.1b). Here, the (ultra)mafic unit is overlain by a large Carboniferous orthogneiss (meta-granite) body (Martínez-Martínez et al., 2010), which is intruded into metasediments (paragneisses and micaschists) of possibly pre-Carboniferous age, interpreted to be part of the same Bédar-Macael unit (version A on Figure 4.2, García-Dueñas et al., 1988; Martínez-Martínez et al., 2010; Martínez-Martínez et al., 2002) or in a different interpretation the Sabinas unit (version B on Figure 4.2, Puga et al., 2002; Puga et al., 2011). The contact between the Carbonifeous and underlying Jurassic (-Cretaceous?) rocks (Figure 4.2) is interpreted to be either a thrust (Puga et al., 2002) or the result of a large-scale recumbent fold with the orthogneiss in its core (García-Dueñas et al., 
1988; Martínez-Martínez et al., 2010; Martínez-Martínez et al., 2002). This controversy is just apparent, since the recumbent fold (if present) must be sheared along the overturned flank to explain the rapid change in age, consequently resembling a thrust geometry (fold nappe). Therefore, we use the former definition and further study the tectonic contact between the (ultra)mafic unit and the overlying orthogneiss (Figures 4.1c, 2).

\subsubsection{Metamorphic conditions and kinematic characteristics of the NFC}

The Calar-Alto unit (Figure 4.2) reached eclogite-grade peak burial metamorphic conditions in the order of $14 \mathrm{kbar} / 550{ }^{\circ} \mathrm{C}$ (Augier et al., 2005a), 20-22 kbar/470-490 ${ }^{\circ} \mathrm{C}$ (Santamaría-López et al., 2019), or 16.2-18.6 kbar/519-543 ${ }^{\circ} \mathrm{C}$ (Li and Massonne, 2018). In the thick metapelite formation, the HP-LT mineral paragenesis consists of garnet, chloritoid, phengite, chlorite, kyanite, and rutile (e.g. Augier et al., 2005a; Booth-Rea et al., 2015). The micaschists and orthogneiss bodies of the Sabinas unit reached similar or slightly higher eclogite-grade peak burial conditions with thermodynamic estimations of $20 \mathrm{kbar} / 520{ }^{\circ} \mathrm{C}$ (Santamaría-López et al., 2019), 10-14 kbar/500-600 ${ }^{\circ} \mathrm{C}$ (Augier et al., 2005a), or 20-22 kbar/550-600 ${ }^{\circ} \mathrm{C}$ (Ruiz-Cruz et al., 2015). The (ultra)mafic unit (Figure 4.2) reached similar eclogite-grade peak metamorphic conditions, developing a mineral paragenesis consisting largely of omphacite, garnet, and phengite in the meta-mafic rocks (e.g. Puga et al., 1999). Thermodynamic estimates of peak metamorphic conditions for the mafic eclogites are in the range of 14-22 kbar/570-675 ${ }^{\circ} \mathrm{C}$ (Puga et al., 2000), 16-17 kbar/680-710 ${ }^{\circ} \mathrm{C}$ (Padrón-Navarta et al., 2010), 20-22 kbar/550-600 ${ }^{\circ} \mathrm{C}$ (Ruiz-Cruz et al., 2015), or $16-22 \mathrm{kbar} / 500-700{ }^{\circ} \mathrm{C}$ (Augier et al., 2005a).

Numerous studies have interpreted that both the continental and (ultra)mafic protoliths experienced an additional episode of heating during their decompression, i.e. exhumation (Booth-Rea et al., 2015; Li and Massonne, 2018; Puga et al., 2000; Santamaría-López et al., 2019), although retrograde P-T paths implying isothermal decompression (Augier et al., 2005a) or cooling during decompression (e.g. Behr and Platt, 2012) have also been reported. Retrograde metamorphism in the metapelites of the Calar-Alto and Bédar-Macael units is characterized by the abundant growth of chlorite, albite, white mica, and quartz, which define the post-HP tectonic foliation(s)(Augier et al., 2005a; Booth-Rea et al., 2015). Following medium-to low-temperure retrograde metamorphism, the NFC experienced significant further cooling and exhumation to (or near) the surface during the late Miocene (Johnson, 1997; Lonergan and Johnson, 2002; Vázquez et al., 2011).

The kinematics of deformation during HP-LT metamorphism in the NFC is unknown due to obliteration during the subsequent moderate-to low-temperature shearing (e.g. Augier et al., 2005a). Retrograde mineral assemblages in the NFC overgrow a relic $\mathrm{S}_{0}$ sedimentary layering and the early, HP-LT, $S_{1}$ tectonic foliation, which is preserved in the deeper sections of the Calar-Alto unit, and is progressively obliterated towards the Marchal shear zone (García-Dueñas et al., 1988), where the $\mathrm{S}_{2}$ or younger foliations become more closely spaced (Augier et al., 2005a; Booth-Rea et al., 2015). The pervasive $S_{2(-3)}$ foliation(s) carries stretching lineations that are dominantly associated with a top-W sense of shear during exhumation, especially close to the main extensional detachment system or Betic Movement Zone (Augier et al., 2005a; Booth-Rea et al., 2015; Martínez-Martínez et al., 2002; Platt and Vissers, 1980). Augier et al. (2005c) furthermore reported the divergence of this generally 
westward shear direction on either limbs of the NFC dome. Retrograde shearing in the formations of the NFC finally transitioned to semi-brittle to brittle shearing and normal faulting along the Betic Movement Zone (Augier et al., 2005c; Martínez-Martínez et al., 2002).

\subsection{Structural and tectono-stratigraphic results}

We complement the extensive available kinematic database by conducting a fieldwork with the aim of detailing the geometry, kinematics, and metamorphic conditions of the main shear zones as well as making new observations regarding the present structural relationship between the original continental and (ultra)mafic protoliths. We build on the already established petrological data and use further field criteria to infer the kinematics of shearing during the established metamorphic stages. To that end we used stretching lineations and associated kinematic indicators such as shear bands (C-S or C'-S structures, Figures 4.3c, 4.4f), or asymmetric porphyroblasts (Simpson and Schmid, 1983) to infer tectonic transport directions under different metamorphic conditions. The measured stretching lineations can be generally grouped in two categories: moderate-temperature (developed $>=450{ }^{\circ} \mathrm{C}$ ), representing near-peak metamorphic conditions prevailing during deep burial and early exhumation (e.g. Booth-Rea et al., 2015), and low-temperature, representing the retrograde metamorphic stage during significant decompression (exhumation) in the NFC (Figures 4.1b, 4.3a, e.g. Augier et al., 2005a). Moderate-temperature stretching lineations are usually defined by black and blue amphiboles and plagioclase in the metamafic rocks. Lowtemperature stretching lineations are defined when arguments for retrograde mineral growth with respect to near-peak conditions were found in the field or thin sections. These are situations when: 1) low-grade minerals, most frequently chlorite and albite (Augier et al., 2005a) overgrow higher-grade fabrics with no moderate-temperature lineation preserved (see also Augier et al., 2005a); 2) a moderate-temperature stretching lineation is still preserved, but it is overprinted by retrograde lineations while keeping the same sense of shear; 3) a moderate-temperature stretching lineation is still preserved in some foliation planes, but a second set of stretching lineations overprint the first set with a different orientation, defined by different minerals, such as chlorite, albite, green amphibole, white mica, quartz or calcite. 


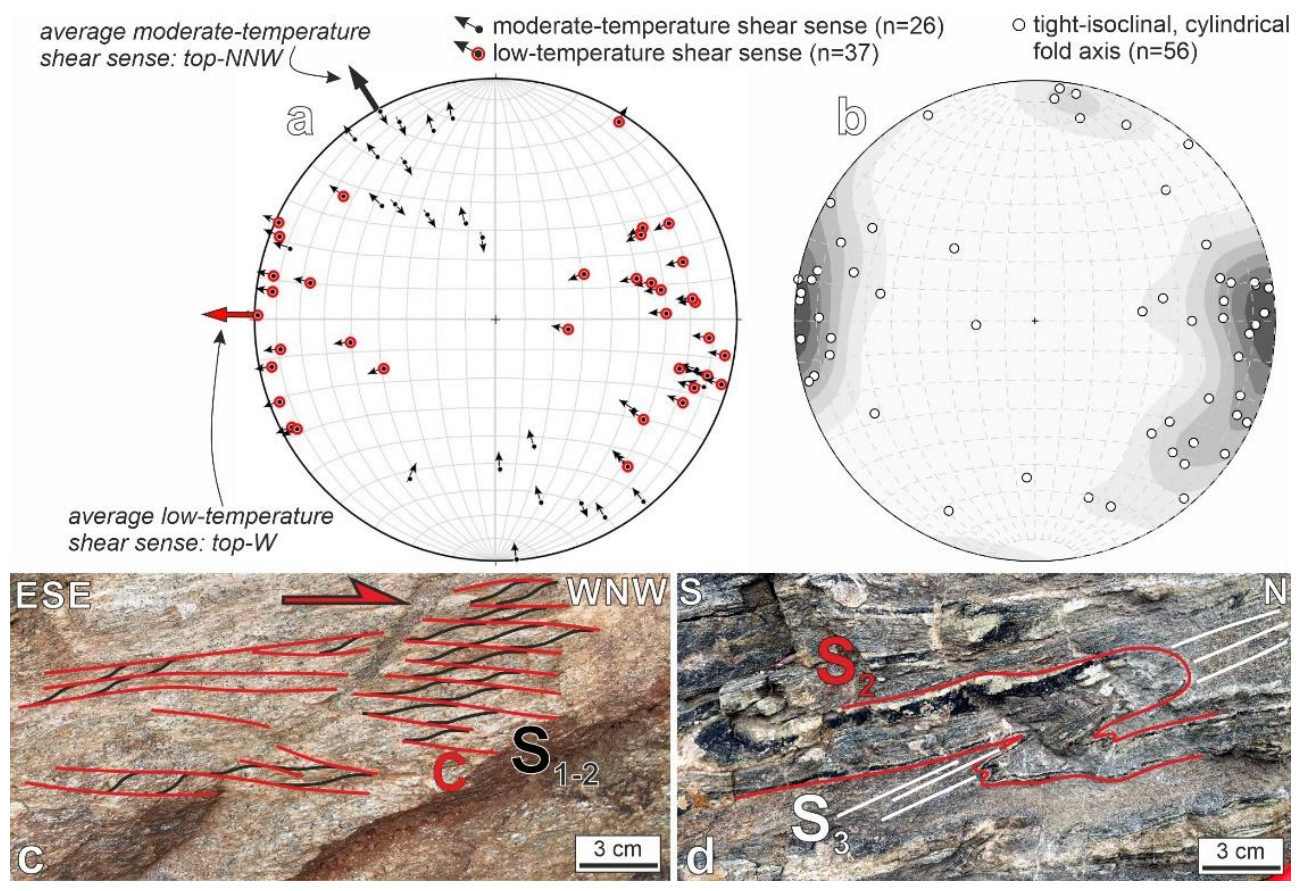

Figure 4.3. (a) Stereographic projection of moderate and low-temperature stretching lineations and associated kinematic indicators (b) Stereographical projection of cylindrical, asymmetric, tight-isoclinal fold axes $\left(\mathrm{F}_{2-3}\right)$. (c) $\mathrm{C}$-S shear fabric in garnet-micaschist at the top of the Ophiolite unit (Cuatro Amigos shear zone) showing top-WNW sense of shear. (d) Tight, asymmetric, Nverging fold $\left(\mathrm{F}_{3}\right)$ in mafic amphibolite showing the crystal-plastic deformation (flow) of plagioclase.

\subsubsection{Kinematics of deformation}

Our kinematic observations are largely similar to previous stuctural studies (e.g. Augier et al., 2005a; Booth-Rea et al., 2015; Martínez-Martínez et al., 2002), with a few key ellements and differences that are herewith described in more details. The NFC in the eastern Sierra de los Filábres displays a gradual change of ductile structural elements from the core of the dome (deeper sections of the Calar-Alto unit) towards its flanks, where the Marchal and Cuatro Amigos shear zones crop out (Figures 4.1b, c). The metapelites in the core of the dome show a distinct succession of folds and related axial planar cleavages that are largely obliterated in the proximity of these shear zones. A generation of early isoclinal folds $\left(\mathrm{F}_{1}\right)$ is only observed in the metapelites of the Calar-Alto unit. These folds affect the $\mathrm{S}_{0}$ sedimentary layering, are generally rootless and transposed into the tectonic foliation of the subsequent folds $\left(S_{2}\right.$, Figures $\left.4.4 a, e\right) . F_{2}$ isoclinal folds are associated with a pervasive $S_{2}$ foliation. The $\mathrm{S}_{0}, \mathrm{~S}_{1}$ and $\mathrm{S}_{2}$ foliations are generally (sub-)parallel in the areas close to the shear zones (composite $\mathrm{S}_{0-2}$ foliation, Figures $4.4 \mathrm{~b}, \mathrm{f}$ ), while in the deeper sections of the Calar-Alto unit $\mathrm{S}_{2}$ foliation defines a strong crenulation cleavage in the meta-pelitic rocks (Figures 4.4a, e). Tight to isoclinal, dominantly asymmetric folds $\left(F_{3}\right)$ refold the pervasive $S_{2}$ foliation and $F_{2}$ isoclinal folds, associated with an occasionally strongly developed $\mathrm{S}_{3}$ tectonic foliation 
(Figure 4.3d). In the shear zones, the tight $\mathrm{F}_{3}$ asymmetric folds are flattened to isoclinal fold geometries and the $S_{3}$ foliation becomes sub-parallel to the $S_{2}$ foliation, making their distinction difficult in places. These two generations of tight-isoclinal, cylindrical folds $\left(\mathrm{F}_{2}\right.$ 3) were measured in all exposed units of the NFC in our study area and show dominant E-W oriented fold axes (Figure $4.3 \mathrm{~b}$ ), and flat $\left(<45^{\circ}\right)$ axial planes. The consistency of the asymmetric fold geometry and the dominantly $\sim \mathrm{N}$-ward vergence (e.g., Figures $4.1 \mathrm{c}$ and 4.3d) implies a significant component of non-coaxial deformation (simple shear) in the formation of these folds. The exception is the El Pilar - El Chive area, where consistent southward vergence of asymmetric $\mathrm{F}_{3}$ folds is observed in the meta-mafic and carbonate rocks (Figures $4.4 \mathrm{a}, \mathrm{d}$ ). $\mathrm{F}_{2-3}$ folds display ductile deformation (flow) and oriented growth of plagioclase and black to blue amphiboles in the meta-mafic rocks, implying that the formation of these folds was coeval with near-peak metamorphism (Figure 4.3d). $\mathrm{S}_{2}$ and subordinately $\mathrm{S}_{3}$ foliation planes carry well-developed stretching lineations. Based on field and micro-structural observations, two generations of stretching lineations can be distinguished. Moderate-temperature stretching lineations show an average top-NNW (top$330^{\circ}$ ) sense of shear, while low-temperature stretching lineations (including a transition from moderate to low-temperature while keeping the same sense of shear) show an average top$\mathrm{W}$ (top-271 ${ }^{\circ}$ ) sense of shear (Figure 4.3a). The more northerly directed tectonic transport during near-peak metamorphic conditions is in agreement with the dominantly E-W trending and $\mathrm{N}$-verging, cylindrical, asymmetric $\mathrm{F}_{2-3}$ folds (Figures $4.3 \mathrm{a}, \mathrm{b}$ ). The westward retrograde shearing implies that tectonic transport direction substantially changed $\left(\sim 60^{\circ}\right)$ from a higher temperature deformation stage to a subsequent lower temperature one. 

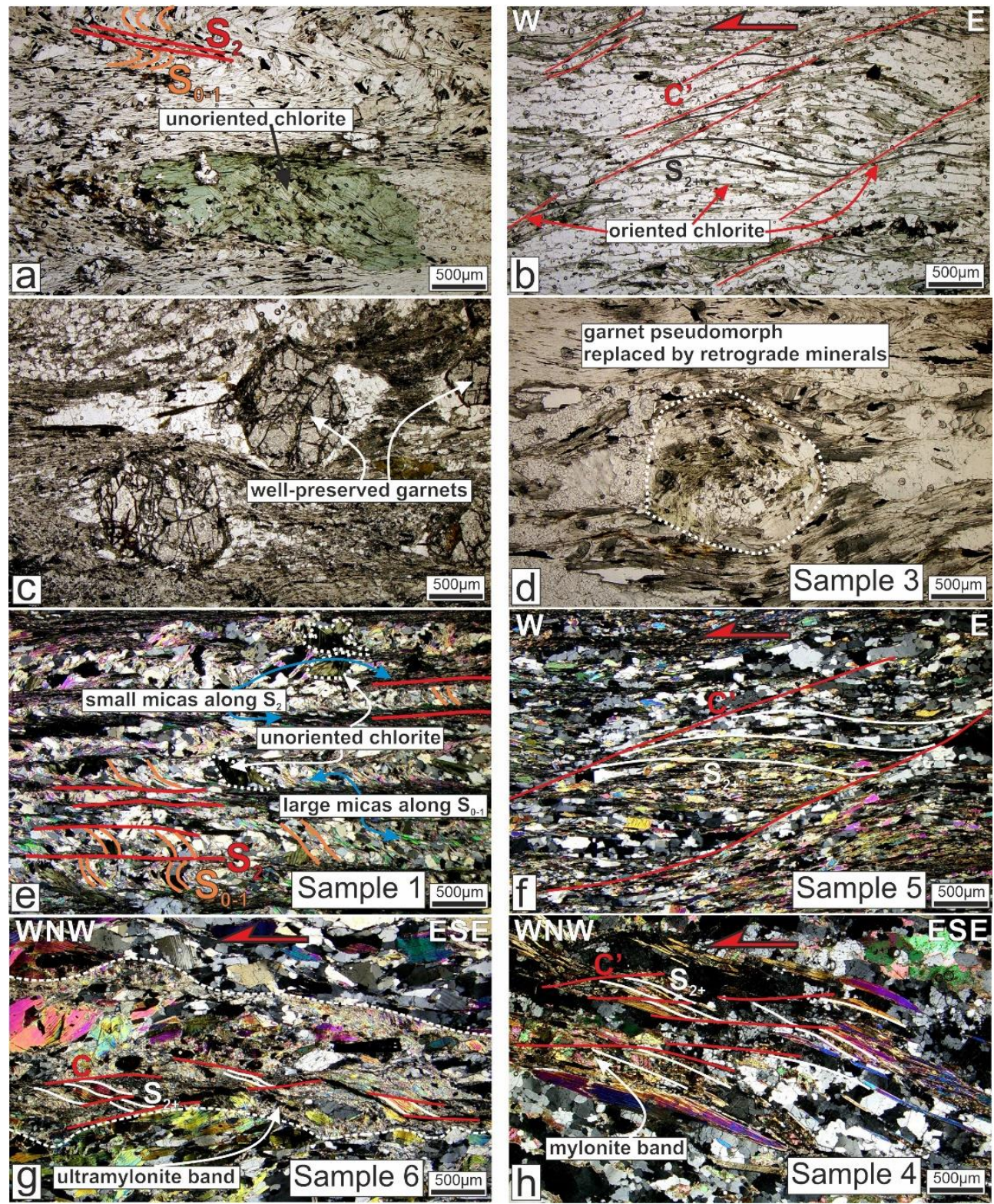

Figure 4.4. Interpreted thin sections photos showing the microstructure of geochronologically dated and other key samples. The sample location is plotted on Figure 4.1b. (a) Plain polarized thin section image of the Tahal formation, outside of the Marchal shear zone (Key outcrop 8 on Figure 4.1b), showing unoriented chlorite growth during retrogression and the preservation of an early $\mathrm{S}_{0-1}$ foliation in relic crenulations. (b) Plain polarized thin section image of the Tahal formation, inside the Marchal shear zone (Key outcrop 9 on Figure 4.1b), showing oriented chlorite growth. Older fabrics $\left(\mathrm{S}_{0}, \mathrm{~S}_{1}\right.$, possibly $\left.\mathrm{S}_{2}\right)$ are completely overprinted by the shear zone foliation. C'-type shear bands imply top-W sense of shear. (c) Plain polarized thin section image of well-preserved garnets in the Sabinas unit (Key outcrop 10 on Figure 4.1b) outside of the main shear zones. (d) Plain polarized thin section image of a garnet pseudomorph within the Cuatro 
Amigos shear zone, largely replaced by white mica and quartz (Sample 3 on Figure 4.1b). (e) Cross-polarized image of Sample 1 showing the preservation of the early $\mathrm{S}_{0-1}$ foliation in crenulations and the unoriented growth of chlorite. Large mica crystals define the $S_{0-1}$ foliation, while small micas define the $S_{2}$ foliation. (f) Cross-polarized image of Sample 5 showing a mylonitic foliation and top-W C'-type shear bands. (g) Cross-polarized image of Sample 6 showing an ultramylonite band associated with top-WNW sense of shear in the orthogneiss of the Sabinas unit. (h) Cross-polarized image of Sample 4 showing mylonite bands associated with topWNW sense of shear directly below the main detachment.

\subsubsection{Shear zones and tectonic units in the eastern Sierra de los Filábres}

Mapping of the main shear zones complimented with new observations regarding the tectono-stratigraphic superposition of the formations, led to the refinement of the commonly used subdivision of tectonic units for the eastern Sierra de los Filábres (Figures 4.1c and 4.2). The base of the Calar-Alto unit is not exposed in our study area. The top of this unit is defined by the Marchal shear zone (García-Dueñas et al., 1988). This shear zone is often observed in mylonitic quartzites and marbles situated in the uppermost part of the Calar-Alto unit or in the marbles and amphibolites situated in the lower part of the Ophiolite unit (Figures 4.1c and 2). The shear zone shows NW-SE to E-W oriented stretching lineations and associated top-NW to W sense of shear (Figure 4.4b). Along the northern flank of the Sierra de los Filábres, a repetition of the the Ophiolite unit is observed (Figures 4.1b, c). The repetition is caused by a reverse-sense shear zone (herewith named Torcal shear zone), which does not exhibit consistent shear sense directions (both top-E and top-W kinematic indicators). The top of the Ophiolite unit is marked by the basal shear zone of the Sabinas unit, herewith named the Cuatro Amigos shear zone, which is observed in the amphibolites, micaschists and calcschists of the Ophiolite unit, and in the Carboniferous orthogneiss of the Sabinas unit. The shear zone exhibit mylonites and ultramylonites, where the observed stretching lineations are dominantly retrograde, trending WNW-ESE associated with a top-WNW sense of shear, as observed, for instance by a well-developed C-S fabric in the micaschists of the Ophiolite unit (Figure 4.3c). Given that the significantly older Carboniferous orthogneiss tectonically overlies the Ophiolite unit, we interpret this contact between the Ophiolite and Sabinas units as an initial thrusting shear zone (the Cuatro Amigos shear zone, Figure 4.2). These observations and their interpretation are not incompatible with the fold-nappe solution described in details by García-Dueñas et al. (1988), with the exception that the overturned flank of the fold-nappe must have accommodated larger amounts of thrusting (shearing) than hitherto assumed. The Sabinas unit is further dissected by multiple shear zones causing a complex repetition of formations including a thin sliver of mafic amphibolites and serpentinites outcropping below Triassic dolomite marbles (Figures $4.1 \mathrm{c}$ ).

\subsubsection{Lithostratigraphy and structure of the Ophiolite unit}

Starting from the lithological composition and the mafic-ultramafic petrography of the Ophiolite unit extensively described by previous studies (e.g. Puga et al., 2011; Puga et al., 1999; Puga et al., 2000), our observations show that the base of this unit generally displays Triassic meta-carbonates (dominantly limestone marbles and subordinately dolomite marbles) folded together with thin layers of meta-mafic rocks (Figures 4.5a, g). The metacarbonates are in most sections overlain by the Jurassic mafic and ultramafic rock succession 
that can reach a thickness of $250 \mathrm{~m}$. Mafic rocks are dominantly fine to coarse grained amphibolites, often containing relics with the texture of the basaltic, doleritic or gabbroic protoliths. The amphibolites are characterized by clearly developed, often mylonitic foliation defined by stretched plagioclase and oriented amphibole crystals. The mineralogical association of the amphibolites often includes epidote and garnet. Other rocks observed are large bodies of serpentinites, locally reaching a thickness of $150 \mathrm{~m}$, (Figure 4.5f), serpentinite-schists, and talc-schists. In the Cobdar area (Figure 4.1b), previous studies have described extensively the structure, composition and petrography of mantle rocks, such as peridotites or cumulus troctolites, affected by a significant degree of metasomatism and alteration from serpentinites to talc, together with gabbros, dolerites and pillow basalts (e.g. Puga et al., 2017; Puga et al., 2011; Puga et al., 1999). The crustal rocks are cut by numerous dykes of (porphyric) basalts and plagiogranites (or plagio-gneisses when metamorphosed) that locally retain the typical sheeted-dykes geometry or composition (Figure 4.5e). The mafic and ultramafic rocks are overlain by calc-schists, garnet-micaschists, and quartzites, interpreted to represent a syn- to post- rift deep-water successions deposited on top of the oceanic rocks (Figure 4.5g, Puga et al., 2011; Tendero et al., 1993). These metasediments cover both the mafic and ultramafic rocks of the Ophiolite unit (Figure 4.5a). The different lithologies of the Ophiolite unit display various vertical superpositions of different rock types due to the effect of several successive deformation phases and is significally omitted in or near the vicinity with the main detachment or associated exhumation shear zones. 

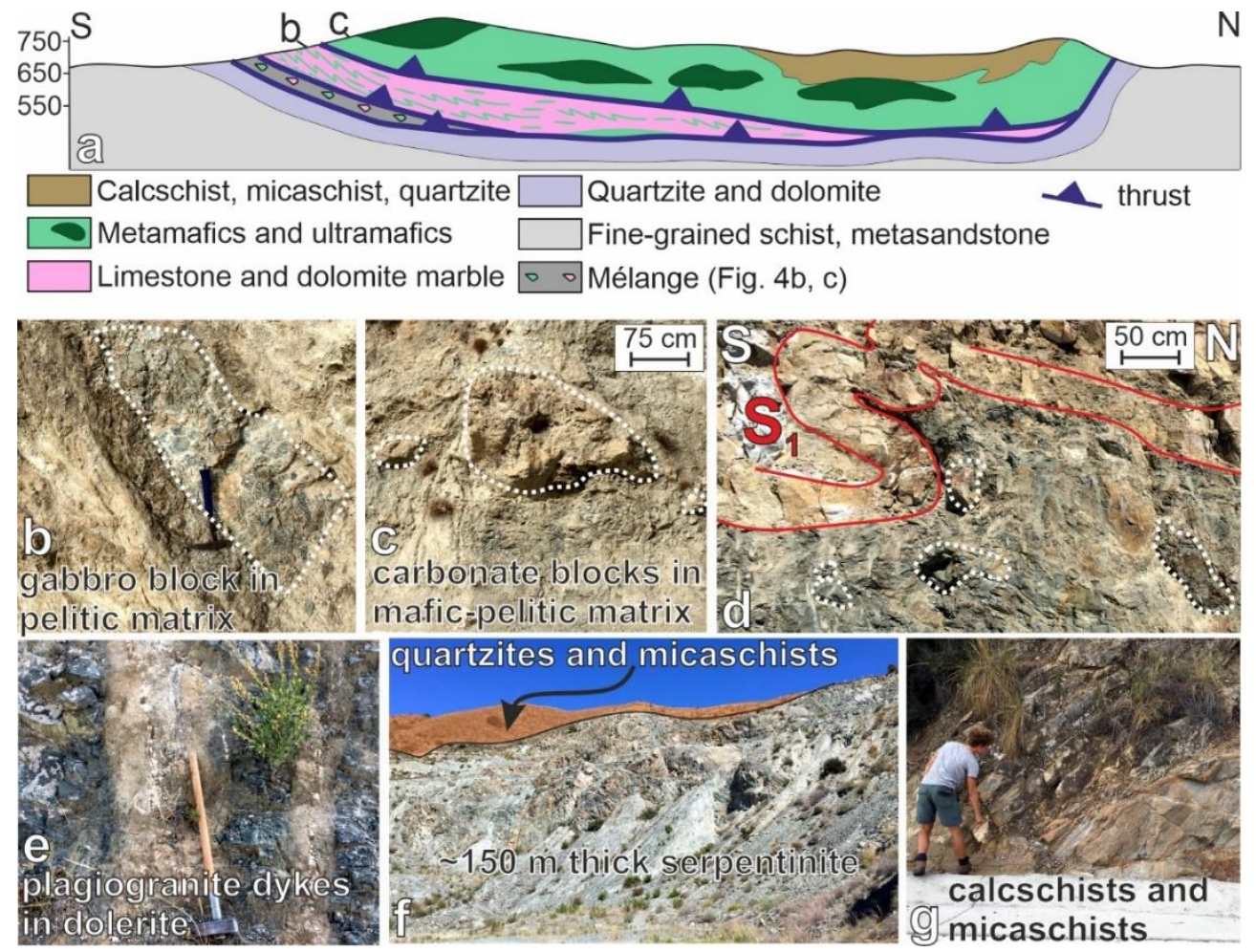

Figure 4.5. Structure and composition of the Ophiolite unit. (a) Cross section through the ophiolite unit at the El Pilar location (for map-view trace of the section see Figure 4.1b). Note the consistent southward vergence of asymmetric folds that affect thin slivers of metamafics and the metacarbonates together. (b) (Meta)Gabbro block in pelitic matrix in the mélange formation of the Ophiolite unit. See hammer for scale. (c) Carbonate block in mafic-pelitic matrix in the mélange of the Ophiolite unit. (d) SSW-verging asymmetric fold in shallow-water carbonates (limestone marble). The carbonate layer is underlain by fine-grained mafic amphibolite displaying several mafic blocks of similar composition. (e) Plagiogranite dykes in dolerite at Cobdar. (f) Thick body of serpentinite covered by quartzites and micaschists. (g) Calcschists and micaschists that cover the mafic and ultramafic formations of the Ophiolite unit.

One key observation not described previously is that the mafic, ultramafic, and sedimentary formations of the Ophiolite unit are often mixed in a mélange that still preserves often the olistostrome structure of the original protolith, despite the superimposed shearing and metamorphism (Figure 4.5a, Figure 4.1b). The mélange is largely made up by a talc, serpentinite or meta-siltic and pelitic matrix, surrounding centimetres to tens of metres sized meta-sedimentary and mafic blocks, such as limestone or dolomitic marbles (e.g., Figure $4.5 \mathrm{c}$ ), quartzites, various types of schists, basalt, dolerite, gabbro (e.g. Figure 4.5b), or metaconglomerates. The mafic blocks often preserve the original gabbroic, doleritic or basaltic texture (e.g., Figure 4.5b) and the surrounding matrix is typically rich in talc, serpentinite and meta-mafic minerals, mixed with meta-sedimentary blocks or matrix, sometimes including secondary gypsum. The proportion of mafic and siliciclastic material is highly variable within 
the mélange. The $S_{2-3}$ foliation is independent of the contacts between different lithologies within the mélange, generally crosscutting throughout the matrix and blocks of various composition, suggesting that the formation of the mélange predate the peak metamorphism. The best preserved section (from El Pilar towards Lubrin along the main road) displays a typical ophiolitic mélange facies, with mafic blocks mixed together with other blocks of meta-sediments, buried in a talc-and serpentinite-rich sedimentary matrix (Figures 4.5a, b, c). The mélange is cut by a series of late normal faults, however, the overall olistostrome structure of the formation is clear (Figures $4.5 \mathrm{a}, \mathrm{b}, \mathrm{c}$ ). The mélange formation outcrops at numerous locations in the eastern Sierra de los Filábres (Figure 4.1b), and exhibit various grades of metamorphism and deformation. The deformation observed in the Ophiolite unit is similar with the one observed in all other units. The exception is the area of the El Pilar and El Chive (Figures 4.1b and 4.4a), where the meta-mafic and ultramafic rocks and the ophiolitic mélange are better exposed and preserved. In this area, a generation of asymmetric folds has been observed, which has a consistent top-SSW vergence (Figure 4.4d), in contrast to the typical $\mathrm{N}$-ward vergence of $\mathrm{F}_{2-3}$ asymmetric folds observed elsewhere.

\subsubsection{Additional tectono-stratigraphic observations in the Low-Grade unit}

Along the northern flank of the Sierra de los Filábres, a tectonic omission creates a significant offset from high-grade to low-grade metamorphic conditions, separated by a zone of retrograde mylonites and cataclasites that marks the previously mapped major extensional detachment, i.e. Betic Movement Zone of Platt and Vissers (1980). The retrogressed mylonites in the footwall largely consists of the garnet-micaschists that overly the mafic and ultramafic rocks of the Ophiolite unit (Figure 4.6a). These garnet-micaschists are characterized by the retrograde growth of chlorite, calcite, and quartz at the expense of the peak metamorphic mineral assemblage (Figure 4.6b). Stretching lineations in chlorite are associated with clear top-W shear sense indicators. The retrograde mylonites are often reworked as cataclasites and cut by numerous normal faults that post-date the cataclastic foliation (Figure 4.6c). The transport direction of the cataclastic shear bands and normal faults are also top-W, in agreement with the ductile kinematic indicators in the retrograde mylonites (Figure 4.6c). 


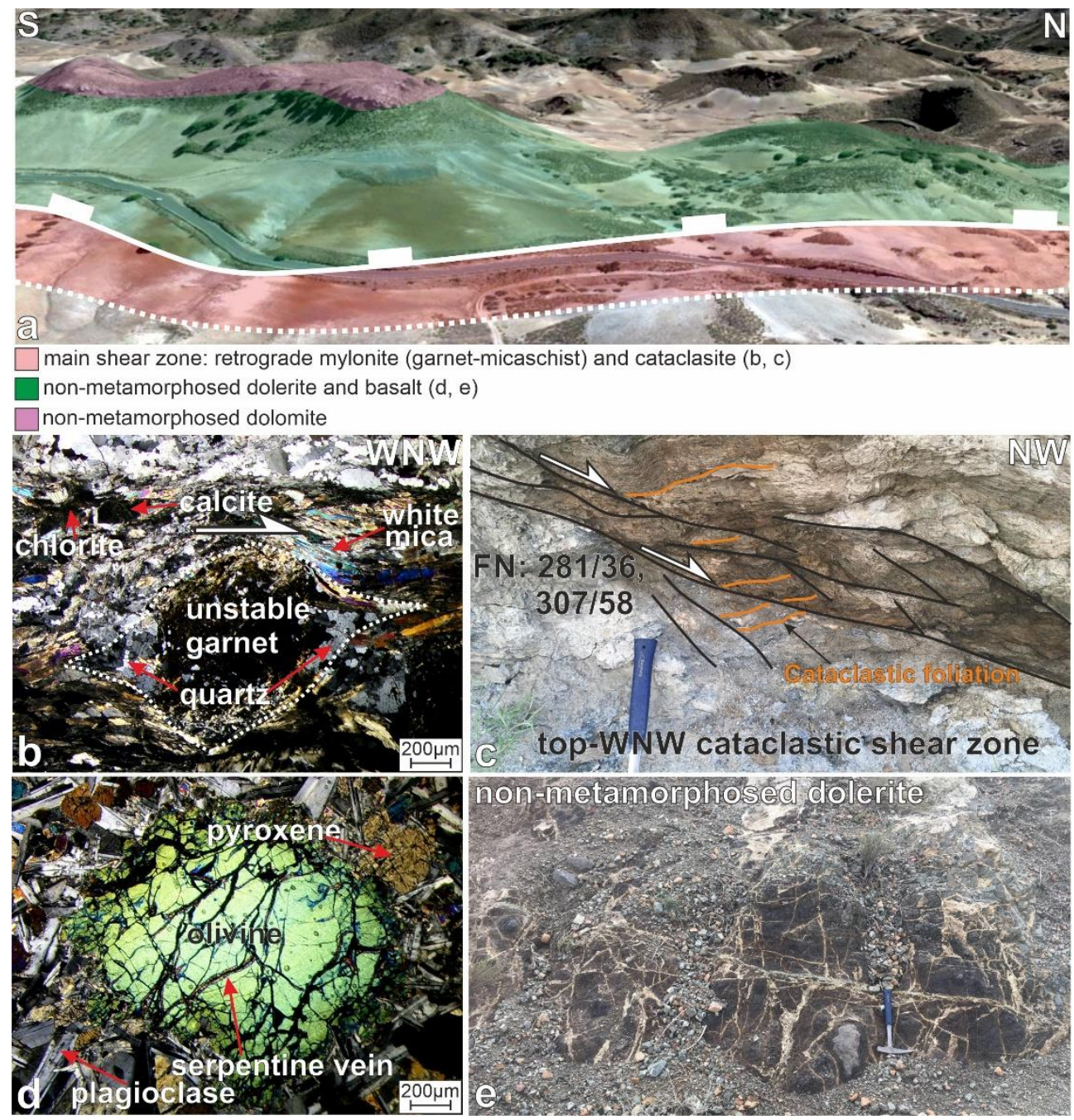

Figure 4.6. (a) Interpreted satellite image showing a typical exposure of the main extensional detachment. The location of the exposure is given on Figure 4.1b (Key outcrop 7). (b) Crosspolarized thin section image of the retrogressed garnet-micaschist directly underlying the detachment. The asymmetry of the garnet+quartz+white mica clast suggests top-WNW sense of shear. (c) Retrograde mylonite reworked as a cataclasite within the main damage zone of the detachment. Cataclastic shear bands and normal faults are dipping towards the WNW. (d) Crosspolarized thin section image of the non-metamorphic dolerite overlying the detachment. The dolerite preserved its original igneous texture and composition. (e) Outcrop image of the nonmetamorphic dolerite.

In the hanging-wall of the detachment, the low-grade formations show significant lithological similarity to the underlying formations of the NFC. The basal formation of the low-grade unit consists of thick successions of metapelites and quartzites that are the lowgrade equivalents of the Permian strata of the Calar-Alto unit. The metapelites only reach the grade of phyllitic cleavage in terms of fabric development, while the quartzites developed a 
less closely spaced tectonic foliation compared to those of the Calar-Alto unit. In some sections, the detachment is directly overlain by non-metamorphosed or very low-grade dolerites and basalts that preserved their igneous textures and mineral composition (Figures $4.6 \mathrm{~d}, \mathrm{e})$. These mafic rocks are the protolith equivalents of the Jurassic meta-mafic crustal rocks (fine and coarse-grained amphibolites) in the Ophiolite unit located beneath the detachment. These mafic rocks are also overlain by dolomites, which do not show a developed tectonic foliation or signs of metamorphic recrystallization, attesting to relatively low metamorphic temperatures (below $400{ }^{\circ} \mathrm{C}$ ). The dolomites are likely the protolith equivalents of the Triassic dolomite marbles observed in the NFC.

\subsubsection{Strain distribution during exhumation (retrograde metamorphism)}

Mapping of structural and metamorphic features with special attention to the superposition of moderate and low-temperature fabrics allowed us to delineate zones where strain localization during retrograde metamorphism (i.e. during exhumation) took place in our study area. A large amount of deformation was accommodated along the extensional detachment system (around $110 \mathrm{~km}$ of extension, Martínez-Martínez et al., 2002), as evidenced by the earlier described tectonic omission from the higher-grade footwall to the low-grade hanging-wall (see also Martínez-Martínez et al., 2002; Platt and Vissers, 1980).

Furthermore, the NFC in the footwall of the detachment records strain localization during the retrograde metamorphism, reflected in the development of retrograde shear fabrics across the dome. The metapelites in the core of the NFC preserve an early $\mathrm{S}_{0-1}$ foliation, overprinted by the dominant $S_{2}$ foliation (Figures $4.4 \mathrm{a}, \mathrm{e}$ ). Both foliations are overgrown by abundant and dominantly unoriented, retrograde chlorite (Figures $4.4 \mathrm{a}$, e), implying that the core of the NFC was not affected by significant deformation during the growth of chlorite. In contrast, the top few tens of meters of the same metapelite formation directly underlying the top-WNW Marchal shear zone shows oriented chlorite growth, defining the dominant stretching lineation and main foliation close to and within the shear zone (Figure 4.4b). This suggest that the Marchal shear zone was active during the exhumation of the NFC, but this deformation did not propagate deeper into the Calar-Alto unit, producing a transition from oriented to unoriented chlorite growth from the flanks to the core of the dome. A similar trend is observed in the upper two tectonic units of the NFC (Ophiolite and Sabinas units). In the proximity of the Cuatro Amigos shear zone, the higher-temperature fabric of the garnetmicaschists is generally replaced by retrograde white mica, chlorite, and quartz (Figure 4.4d). Furthermore, the oriented growth of chlorite at the expense of the higher-temperature fabric is observed in the micaschists and metamafics of the Ophiolite unit, as well as in the orthogneiss of the Sabinas unit. The orthogneiss also exhibits bands of ultramylonites associated with top-WNW sense of shear and growth of retrograde minerals such as sericite or chlorite (Figure 4.4g). Further away from the shear zone, garnets are typically better preserved (Figure 4.4c), retrograde stretching lineations are less frequent, and the dominant higher-grade sense of shear (top-NNW) is better preserved (Figure 4.1b). These observations suggest that the Cuatro Amigos shear zone was also active during the retrogression and thus exhumation of the NFC, similarly to the Marchal shear zone. 


\section{$4.4{ }^{40} \mathrm{Ar} /{ }^{39} \mathrm{Ar}$ dating}

\subsubsection{Methodology}

${ }^{40} \mathrm{Ar} /{ }^{39} \mathrm{Ar}$ dating of white micas was performed with the objective to constrain the timing of metamorphic fabric formation and the activity of shear zones in our study area by selecting 6 samples from key areas of the eastern Sierra de los Filábres (Figure 4.1b, see Figures 4.4d$\mathrm{h}$ for thin section images of dated samples). We applied the ${ }^{40} \mathrm{Ar} /{ }^{39} \mathrm{Ar}$ dating of large $(\geq 250$ $\mu \mathrm{m})$ white mica crystals with the multiple single grain fusion dating method (Uunk et al., 2018). The applicability of white mica ${ }^{40} \mathrm{Ar} /{ }^{39} \mathrm{Ar}$ single grain fusion dating approach for the detection tectono-metamorphic events has been proven by numerous works (Lips et al., 1998; Lister and Forster, 2016; Porkoláb et al., 2019b; Uunk et al., 2018; Wijbrans et al., 1990). The resetting of white mica Ar-systems may be achieved by thermal diffusion (allowing to constrain the timing of cooling below the closure temperature) or by deformation-induced or fluid-assisted (re)crystallization, which allows to constrain the timing of metamorphic fabric formation (e.g. Villa, 1998; Wijbrans and McDougall, 1986). Temperature-dependent resetting of white micas is a gradual process, and depends not only on the temperature itself but also on the duration of the overprinting event (Wijbrans and McDougall, 1986), as well as on the grain radius (de Jong et al., 1992). Hence, in case the metamorphic temperature was high enough and maintained long enough to reset all (small and large) mica crystals, homogenous age distribution of the dated single grains are expected (i.e. a single tectonometamorphic event will be detected by the dated grains). In case one criteria was only partially sufficient, partial resetting may take place, producing heterogeneous age distribution, i.e. detecting multiple resetting events and mixed ages in between (Lister and Forster, 2016; Uunk et al., 2018; Warren et al., 2012b). Complete resetting of the white mica Ar-system by thermal diffusion is thought to require temperatures higher than typical values of greenschist-blueschist facies metamorphism (> $500{ }^{\circ} \mathrm{C}$, Harrison et al., 2009; Warren et al., 2012b). If temperatures were not high enough (or the duration of heating not long enough) to reset the white mica Ar-system by thermal diffusion, some (or all) of the grains can still be reset by deformation-induced or fluid-assisted crystallization due to the formation of a tectonic foliation, producing similar homogenous or heterogeneous grain age distributions (Lister and Forster, 2016; Porkoláb et al., 2019b; Villa, 1998).

White mica crystals of the crushed samples were separated from 250-500 $\mu \mathrm{m}$ sieve fractions using a Faul vibrating table and heavy liquid density-based separation. Carbonate and dust contamination were removed by $\mathrm{HNO}_{3}$ treatment of the samples. Mica separates from 6 samples were selected for single grain fusion dating. The samples were packed in aluminium foil packages and stacked in an aluminium tube that was irradiated for 18hours in the CLICIT facility of the Oregon State University TRIGA Reactor. For both irradiations the neutron flux was monitored by standard bracketing with the DRA sanidine standard with an age of $25.52 \pm 0.08 \mathrm{Ma}$, modified from Wijbrans et al. (1995) to be consistent with Kuiper et al. (2008). Single grain fusion experiments were carried out in the Vrije University Amsterdam argon geochronology laboratory with $25 \mathrm{~W} \mathrm{CO}_{2}$ laser heating samples loaded on Cu-trays (185 individual $2 \mathrm{~mm}$ diameter, $3 \mathrm{~mm}$ deep holes for single grains). The sample holder was connected to a three-stage extraction line and a quadrupole mass spectrometer (Schneider et al., 2009). Data was reduced in ArArCalc 2.50 (Koppers, 2002). Procedure 
blanks were monitored and diluted air shots were measured in the sequence to track mass discrimination.
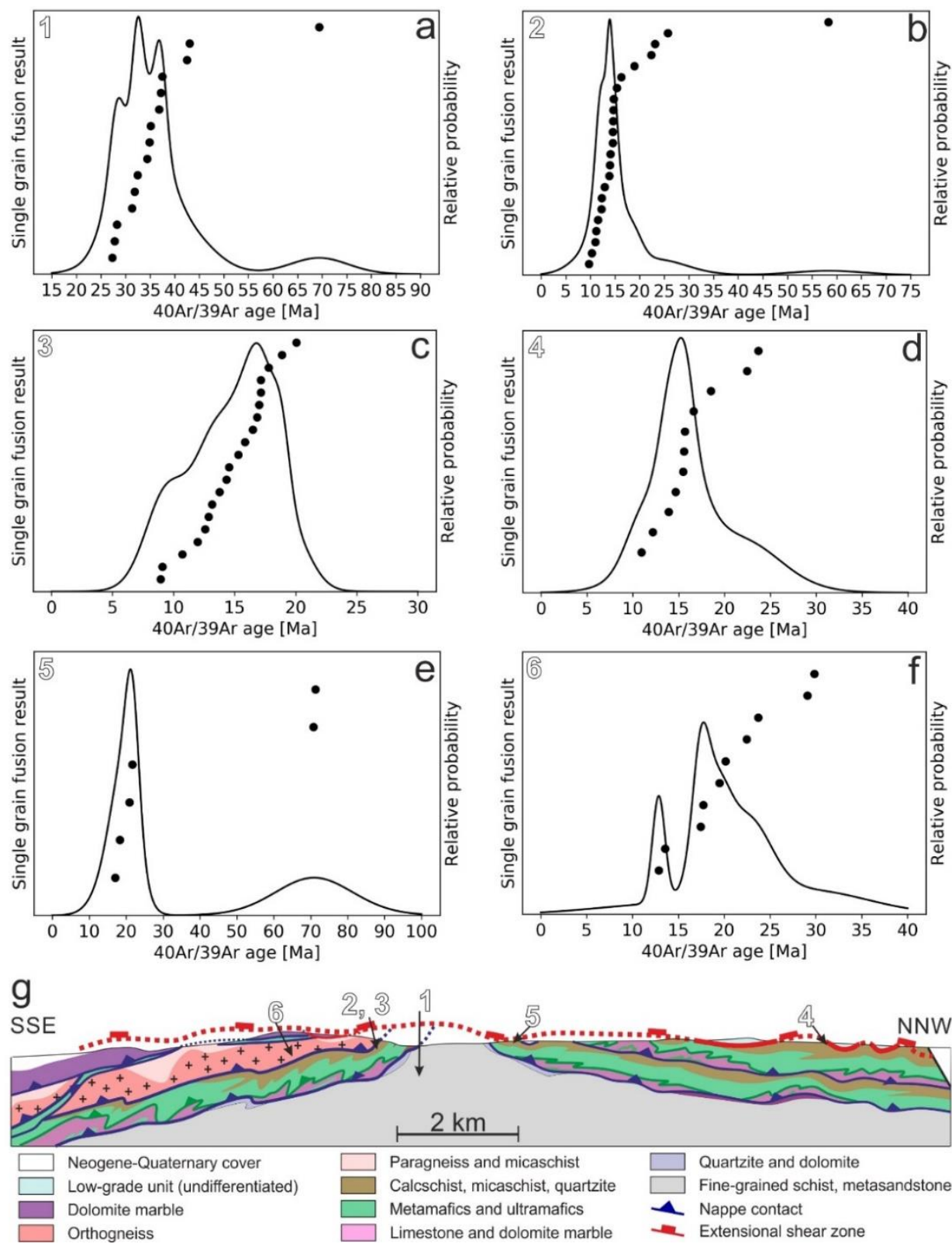

Figure 4.7. Results of single grain fusion white mica ${ }^{40} \mathrm{Ar} /{ }^{39} \mathrm{Ar}$ dating. (a)-(f) Plots of ${ }^{40} \mathrm{Ar} /{ }^{39} \mathrm{Ar}$ ages, where numbers indicate sample codes (for the map location of dated samples see Figure 4.1b). Black circles represent individual dated grains. Black lines show the relative probability, i.e. the cumulated 1-sigma normal distributions of every grain age in the samples. Peaks in the black lines hence show most likely dates of resetting in the samples. (g) Cross-section through our study area showing the projected locations of the dated samples. 


\subsection{2 ${ }^{40} \mathrm{Ar} /{ }^{39} \mathrm{Ar}$ dating results}

The dated samples show a variety in age results as well as in the distribution of the single grain ages within individual samples. A group of three samples (samples 2, 3, and 4) display homogenous single grain age distributions with a relative probability peak at $\sim 15$ Ma (Figures $4.7 \mathrm{~b}, \mathrm{c}, \mathrm{d}$ ), suggesting a single dominant process of resetting in these samples. The grains that define the $15 \mathrm{Ma}$ probability peak show ages between 12 and $22 \mathrm{Ma}$. Some grains with significant deviation from the mean are still present in these samples, showing older (20-25 Ma) or younger (10-12 Ma) ages. Sample 2 shows an outlier grain with substantially older (57 Ma) age, possibly related to incomplete (partial) resetting. Sample 1 also shows a largely homogenous age distribution, however, the peak relative probability of the ages is significantly older, $\sim 33 \mathrm{Ma}$ (Figure $4.7 \mathrm{a}$ ). The grains that define the probability peak are between 27 and $38 \mathrm{Ma}$, while two outlier grains are present in between 40 and 45 $\mathrm{Ma}$, and one grain at $70 \mathrm{Ma}$. Sample 5 contains 4 grains close to $20 \mathrm{Ma}$, and further two at $70 \mathrm{Ma}$ (Figure 4.7e), while sample 6 shows the most heterogeneous age distribution with three groups of grains at 12-14 Ma, 17-24 Ma, and 28-30 Ma (Figure 4.7f).

The location and microstructure of the dated samples highlight the possible importance of the age differences between Sample 1 and all the other samples (Figure $4.7 \mathrm{~g}$ ). Sample 1 was collected from the pelitic schist formation of the Calar-Alto unit, relatively far from the major shear zones in the area. This sample is the only one to preserve $S_{0-1}$ foliation in crenulations (Figure 4.4e), and thus probably preserved earlier mica generation(s) compared to the other samples (Figures $4.4 \mathrm{f}, \mathrm{g}, \mathrm{h}$ ). Furthermore, the grain size of the white micas in the relic $S_{0-1}$ foliation (typically $100-300 \mu \mathrm{m}$ ) is substantially larger than the grain size of white micas in the pervasive $S_{2}$ foliation (typically $50-150 \mu \mathrm{m}$, Figure $4.4 \mathrm{e}$ ). Hence, the dated micas most likely belong to the older $\mathrm{S}_{0-1}$ foliation, as all the selected single grains were larger than $250 \mu \mathrm{m}$. The mean age of $33 \mathrm{Ma}$ of this sample is significantly older than the mean age of the other samples (15-20 Ma) which were collected near (sample 6) or from the major shear zones (samples 2, 3, 4, 5, Figure 4.7g). In these samples the oldest $\mathrm{S}_{0-1}$ foliation is completely obliterated by the superposed foliation and shear fabric development due to shear zone activity, resulting in the formation of $S_{2}$ or younger shear zone foliations (Figures $4.4 \mathrm{f}, \mathrm{g}, \mathrm{h}$ ). Samples 2, 3, and 5 were collected from micaschists of the Ophiolite unit, incorporated into the shear zone that emplaced the Carboniferous formations of the Sabinas unit on top of the Ophiolite unit. The shear zone was later likely reactivated (or progressively used) during the exhumation of the NFC (see Section 3.2.3). Sample 4 was collected from the retrograde garnet-micaschists incorporated in the major extensional detachment that separates high-grade and low-grade units, while sample 6 was collected from a mylonitic horizon of the Carboniferous orthogneiss of the Sabinas unit. 


\subsection{Discussion}

\subsubsection{Interpretation of ${ }^{40} \mathrm{Ar} /{ }^{39} \mathrm{Ar}$ ages and timing of tectono-metamorphic events}

Our results are in agreement with in-situ laser ${ }^{40} \mathrm{Ar} /{ }^{39} \mathrm{Ar}$ white mica ages reported by Augier et al. (2005a), which shows older $\sim 45-25 \mathrm{Ma}$ ages for the preserved $\mathrm{S}_{0-1}$ foliation when compared with the $\sim 22-12 \mathrm{Ma}$ ages in places where such foliation was overprinted by the fabric of a shear zone.

Numerous studies have shown that Ar-loss in white micas is a complicated process, where thermal diffusion might only play a limited role in the resetting of the Ar-system, particularly when significant deformation or fluid flow is present in the given rock volume (Harrison et al., 2009; Lister and Forster, 2016; Uunk et al., 2018; Villa, 1998; Warren et al., 2012b). Our results and those of Augier et al. (2005a) indicate that structural criteria (preservation of a tectonic foliation) correlate with the age results, which implies that temperature is not the dominant mechanism of resetting. We hence argue that the dominant resetting mechanism in our samples was deformation-and possibly fluid-induced (re)crystallization during the development of tectonic foliations. Along these lines white micas constituting an older foliation $\left(\mathrm{S}_{0-1}\right)$ in the metapelites of the Calar-Alto unit yield older age clusters compared to samples where micas constitute younger fabrics $\left(S_{2}\right.$ or younger foliations developed during shear zone activity). Furthermore, these samples are located at a distance of ca, 1-2 km below the main shear zones (Marchal shear zone, see Figure 4.1c and Figure 1d in Augier et al., 2005a)) and do not exhibit evidence for significant deformation during the activity of the overlying shear zones (22-12 Ma). Hence, we assume a very limited deformation-or fluid flow-induced Ar-loss in these samples during the activity of the main shear zones. It follows that peak temperatures (ca. $470-550{ }^{\circ} \mathrm{C}$ ) in the Calar-Alto unit (Augier et al., 2005a; Li and Massonne, 2018; Santamaría-López et al., 2019) were not high enough (or not sustained long enough) to facilitate efficient thermal diffusion in the metapelites.

Several studies have suggested that excess argon might be responsible for the presence of older than Early Miocene white mica ${ }^{40} \mathrm{Ar} /{ }^{39} \mathrm{Ar}$ ages in the NFC (Behr and Platt, 2012; de Jong, 2003; De Jong et al., 2001; Kirchner et al., 2016; Platt et al., 2006). Excess argon incorporation in white micas has been attributed to sub-microscopic illitization during latestage hydraulic fracturing, where the density of the fracture network controls the grade of illitisation and hence the amount of excess argon incorporation on the scale of individual grains (De Jong et al., 2001). This process resulted in highly varying ${ }^{40} \mathrm{Ar} /{ }^{39} \mathrm{Ar}$ ages in samples of the Carboniferous orthogneiss, somewhat similar to sample 6 in our study taken from the same formation (Sabinas unit, Figures 4.2 and 4.7). In this sense, significant age variations in sample 6 , and possibly the significantly older, outlier grains in the other samples could also be explained by excess argon incorporation, not only by partial resetting (inherited argon). However, sample 1 shows a consistent, homogenous distribution of older ages between 27 and $38 \mathrm{Ma}$, which do not exhibit the typical variance caused by excess argon. In addition, the effect of excess argon (if present) is expected to be more profound in the coarser grained rocks such as the micaschists of the Ophiolite unit (samples 2, 3, 4, 5, yielding 1222 Ma grains) compared to the fine grained schists of the Calar-Alto unit (sample 1, yielding 27-38 Ma grains), therefore predicting that sample 1 should be less affected by this process (De Jong et al., 2001). Consequently, the above described correlation of the observed 
structural criteria (preservation of an older foliation far from the shear zones) with the older age clusters demonstrated in Augier et al. (2005a) and in this study is a more logical explanation for the variety of age data than assuming an unclear presence of excess argon in those samples. All these arguments consedered, we interpret our white mica ${ }^{40} \mathrm{Ar} /{ }^{39} \mathrm{Ar}$ ages as a record of two different fabric forming periods, i.e. (re)crystallization of white micas as a result of deformation events: 1) a Paleogene fabric evolution recorded by Sample 1 in the Calar-Alto unit (38-27 Ma), and 2) an Early-Middle Miocene fabric evolution recorded by the samples within or in the proximity of the main shear zones (22-12 Ma). Outlier grains (4 grains in all samples) with significantly older age results (60-70 Ma) and the significant age variation (heterogenous distribution) in sample 6 are possibly the result of inherited or excess argon in the samples.

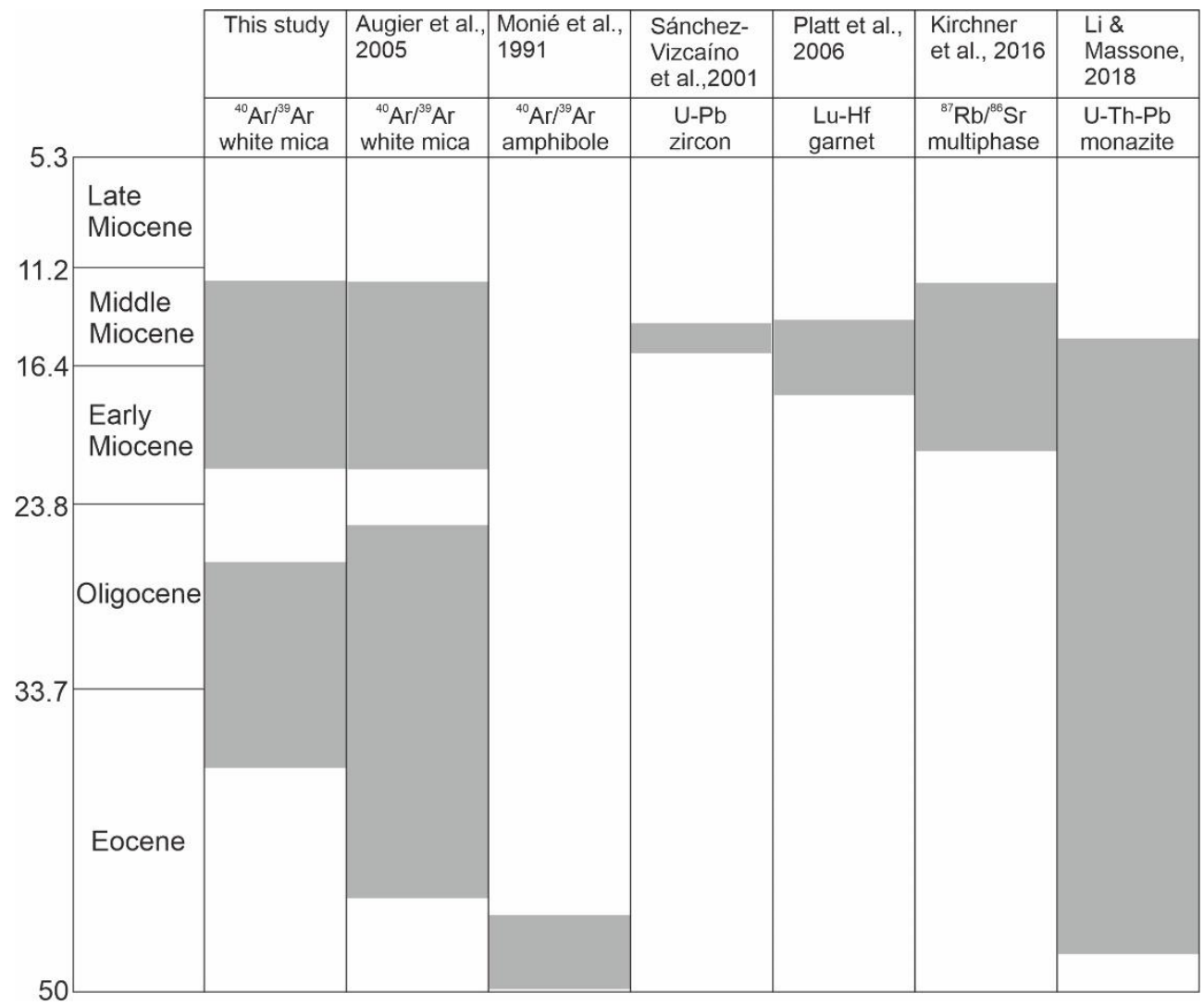

Figure 4.8. Summary of published geochronological results constraining the timing of tectonometamorphic events in the NFC.

Accounting for the full range of existing geochronological ages (Figure 4.8) shows that our Paleogene white mica ${ }^{40} \mathrm{Ar} /{ }^{39} \mathrm{Ar}$ ages and those of Augier et al. (2005a) are in agreement with amphibole ${ }^{40} \mathrm{Ar} /{ }^{39} \mathrm{Ar}$ and monazite U-Th-Pb data (Li and Massonne, 2018; Monié et al., 1991). Miocene U-Pb zircon, Lu-Hf garnet and ${ }^{87} \mathrm{Rb} /{ }^{86} \mathrm{Sr}$ multimineral ages that are supplemented by thermodynamic data constraining the P-T conditions of the dated minerals outline a second episode of prograde, HP-LT metamorphism (Kirchner et al., 2016; Platt et al., 2006; Sánchez-Vizcaíno et al., 2001). Accepting both sets of ages and their interpretations 
as burial-related metamorphism, we argue that the NFC might have experienced two phases of burial, in the Paleogene and subsequently in the Miocene.

\subsubsection{Superposition of Miocene thrusting and extension: the mechanics of exhumation and the structural definition of the NFC and the AC}

Our results suggest that the main nappe contacts of eastern Sierra de los Filábres formed during near-peak metamorphic conditions, with a kinematics of top to NW-NNW in presentday orientation. Furthermore, these shear zones display significant evidences of activity during the retrogression and exhumation that took place with a general top to WNW-WSW kinematics (in present-day coordinates). This observation implies that kinematics of the shear zones progressively changed from top to NW-NNW shearing during burial and possibly early exhumation to top to WNW-WSW shearing during the subsequent exhumation to mid-crustal levels. This significant change in the sense of shear during exhumation implies a different strain and stress pattern for mid-crustal levels compared to the subduction zone, most likely related to the localization of the main, top-WNW-WSW extensional detachment system at the brittle-ductile transition zone (BDTZ, Martínez-Martínez et al., 2002). Our results hence indicate that the exhuming NFC nappes were captured by the extensional detachment when reaching the BDTZ, which facilitated their further (final) exhumation and resulted in oblique shearing with respect to the nappe stacking direction (Figure 4.9). This interpretation is consistent with existing extrusion models of the NFC, where the formation of the extensional detachment system at the brittle-ductile transition zone took place coevally with the contractional exhumation (i.e. extrusion) of the NFC (Behr and Platt, 2012; Booth-Rea et al., 2015; Booth-Rea et al., 2005). These interpretations are further supported by the observation of E-W trending upright folding, related to N-S contraction, interpreted to be coeval with the formation of the extensional detachment system (Augier et al., 2005a; Martínez-Martínez et al., 2002). Therefore, in agreement with these studies, we interpret the exhumation of the NFC to be the result of an interplay between the extrusion of subducted crust in the deeper segments of the subduction zone, and coeval upper crustal extension in the orogen (Figure 4.9).

Established models of extrusion have shown that nappe formation and exhumation of deeply subducted continental material creates uplift and associated extension in the orogenic upper crust (Chemenda et al., 1997; Chemenda et al., 1996; Hacker et al., 2000; Herwegh et al., 2017; Platt, 1986). Applying these models to the Betics implies that the initial buoyancydriven extrusion of the subducted NFC may have triggered uplift and hence the localization of the extensional detachment system, which in turn accommodated the extrusion of the subducted crust. The extrusion of the NFC and the localization of the detachment system was facilitated by the westward migration of the slab, that created space for rock exhumation as well as for asthenospheric upwelling, which resulted in the observed high-T overprint (reheating) of the NFC during exhumation (Booth-Rea et al., 2015; Booth-Rea et al., 2005; Santamaría-López et al., 2019). The highly oblique (almost orthogonal) kinematics of the top-W or SW detachment compared to the original, top-NW nappe stacking direction (Figure 4.9, Behr and Platt, 2012; Martínez-Martínez et al., 2002; Platt et al., 2003a) is more compatible with an orogen-parallel (or trench parallel) extension mode that creates elongation domes associated with orogen perpendicular shortening during orogenic building 
(e.g. Brun, 1983; Rey et al., 2011), as previously suggested for the NFC (e.g. Behr and Platt, 2012; Martínez-Martínez et al., 2002), or observed elsewhere, such as in case of the Tauern or Danubian windows of the Eastern Alps and South Carpathians (e.g. Matenco and Schmid, 1999; Scharf et al., 2013).

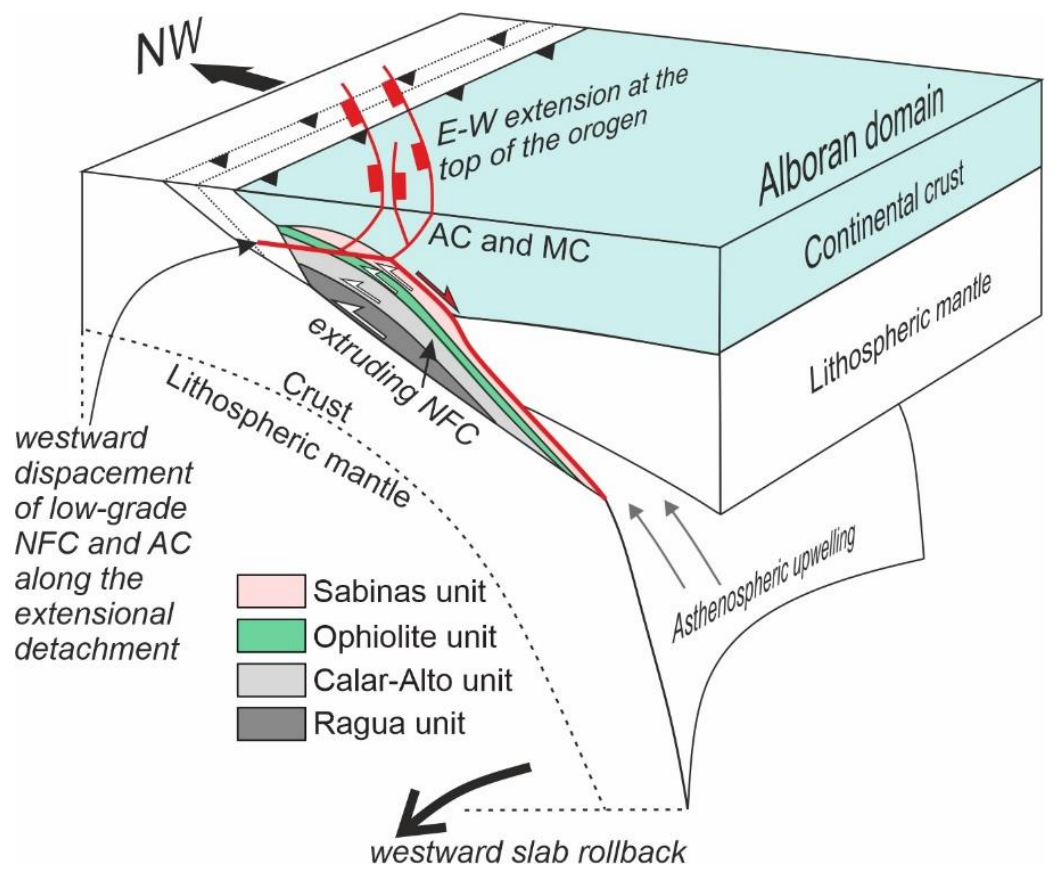

Figure 4.9. Schematic 3D sketch of the early exhumation (extrusion) stage of the NFC in the Early-Middle Miocene showing the superposition of nappe stacking and extensional detachment formation. Note that the original, $\sim$ top-NW nappe contacts were obliquely cut by the $\sim$ top-W extensional detachment that localized at the brittle-ductile transition zone. Therefore, it is possible, that low-grade and high-grade metamorphic equivalents of the same formations from the same nappe units are juxtaposed by the detachment.

The NFC and AC are not only defined as tectonic units, but also as paleogeographic units juxtaposed by thrusting in a subduction zone. To arrive at such interpretations, their definition must be based on the modern nappe structure (i.e. different units bounded by thrusts). However, the current definition of the AC and the NFC is also based on a contrast in metamorphic grade, created by a tectonic omission along an extensional detachment, instead of the original thrusts (Martínez-Martínez et al., 2002). Using a detachment between the AC and NFC as a nappe definition would be valid if the extensional detachment reactivated exactly the original nappe contacts, with an opposite sense of shear. This way of reactivating nappe contacts has been interpreted elsewhere in the Mediterranean to be an important mechanism of exhumation of metamorphic rocks (e.g., Jolivet et al., 2010). However, in case of the Betics, the highly oblique kinematics of the superposed nappe stacking and extension implies that the detachment obliquely cut through the nappe-stack (Figure 4.9), creating a tectonic omission between the NFC and the AC, and possibly reactivating pre-existing shear zones during the late-stage formation of the extensional dome (see also Martínez-Martínez et al., 2002). 
Due to the oblique displacement along the detachment with respect to the original nappe stacking shear zones, low-grade metamorphic formations that originally belong to the NFC are also expected to be observed in the hangingwall of the detachment, overlying their highgrade stratigraphic equivalents in the footwall (Figure 4.9). Examples for such formations could be the low-grade or non-metamorphosed basalts, dolerites, and gabbros (Figure 4.6), which are the protoliths of the high-grade amphibolites or eclogites in the Ophiolite Unit across the detachment. Similarly, the low-grade lithologies commonly assigned to the AC along the northern flank of the eastern Sierra de los Filábres such as Paleozoic phyllites and Triassic dolomites have high-grade equivalents below the detachment (schists and dolomite marbles). Therefore, we suggest that due to the oblique superposition of nappe stacking and extension, the low-grade formations in our study area are not necessarily part of the AC, but may also be part of the NFC in terms of paleogeographic provenance. Ultimately, we conclude that a separation between the extensional detachment creating the observed tectonic omission and the nappe stacking reflecting the paleogeographic provenance of continental units should be further pursued in the Sierra de los Filábres and elsewhere in the Internal Betics.

\subsubsection{Origin and emplacement of the (ultra)mafic unit}

The mafic-ultramafic rock succession of the NFC is most commonly interpreted in the context of a magma-poor, hyper-extended (Iberian-derived) continental margin, which contains intruded mafic dykes as well as areas with mantle rocks exhumed to the seafloor (e.g. Booth-Rea et al., 2015; Gomez-Pugnaire and Munoz, 1991; Laborda-López et al., 2020). The same rock succession is also interpreted as a separate tectonic unit (Ophiolite unit, Puga et al., 2002; Puga et al., 2011), representing the metamorphosed remanants of an independent ophiolite sheet. Our observations are consistent with large parts of both interpretations, which in our view are not exclusive.

A key observation is the presence of a mixture of sedimentary and (ultra)mafic rocks, interpreted as an ophiolitic mélange. The combination of an olistostrome and a shear zone is typical for an ophiolitic melange, which forms by gravity emplaced (ultra)mafic blocks and rocks scraped from the undelying continental formations. The different blocks are buried in a sedimentary matrix derived partly from alteration reactions of (ultra)mafic minerals, and are thrusted by ophiolite sheets during their obduction over continental margins (Figure 4.10c). Such ophiolitic mélanges have been described from ophiolite complexes worldwide (Andersen et al., 1990; Schmid et al., 2008; Yilmaz and Maxwell, 1984). We argue that the mélange of the (ultra)mafic unit cannot simply represent a brittle shear zone where the different lithologies are mixed in the damage zone, because the sedimentary olistostrome fabric of the original protolith is still preserved in some outcrops (e.g. Figure 4.5b, c), although sheared during burial and sometimes also cut by late extensional shear zones and normal faults during exhumation.

The interpretation of an ophiolitic mélange associated with an obduction of ophiolites does not exclude the presence of a hyper-extended continental margin, whose continental mantle could have been connected to - a probably narrow or embryonic - oceanic lithosphere (Fig. 10b). Therefore, there is no conflict between ophiolite and hyper-extended continental margin interpretations, because both can be part of the same paleogeographic domain. 
These considerations can be placed in the context of two alternative scenarios. If we account for our Paleogene geochronological ages (Figure 4.8) to reflect tectonic burial and metamorphism, an obducted oceanic lithosphere connected with a hyper-extended continental margin could provide the overburden required for the burial metamorphism. The obduction of oceanic lithosphere or arc-continent collisions are commonly associated with the regional burial metamorphism of continental margins (e.g. Agard and Vitale-Brovarone, 2013; Goffé et al., 1988; Porkoláb et al., 2021; Pourteau et al., 2013; van Hinsbergen et al., 2016). In this preferred scenario, the Paleogene white mica ${ }^{40} \mathrm{Ar} /{ }^{39} \mathrm{Ar}$ ages of the relic $\mathrm{S}_{0-1}$ foliation could be explained by burial metamorphism during obduction (Figure 4.10c), whose record is preseved only in the deeper sections of the Calar-Alto unit, at far distances from the Miocene shear zones (Figure 4.7g).

In the alternative scenario where the Paleogene geochronological ages are not interpreted as burial metamorphism, the Miocene subduction of the entire NFC is the simplest solution (Booth-Rea et al., 2015; Kirchner et al., 2016; Platt et al., 2006; Sánchez-Vizcaíno et al., 2001). We also consider this interpretation as entirely valid, since the debate on the reliability of different geochronological data appears to be far from over. However, these interpretations should also account for an oceanic lithosphere connected to the hyperextended Iberan margin, and explain the presence of the ophiolitic mélange. 


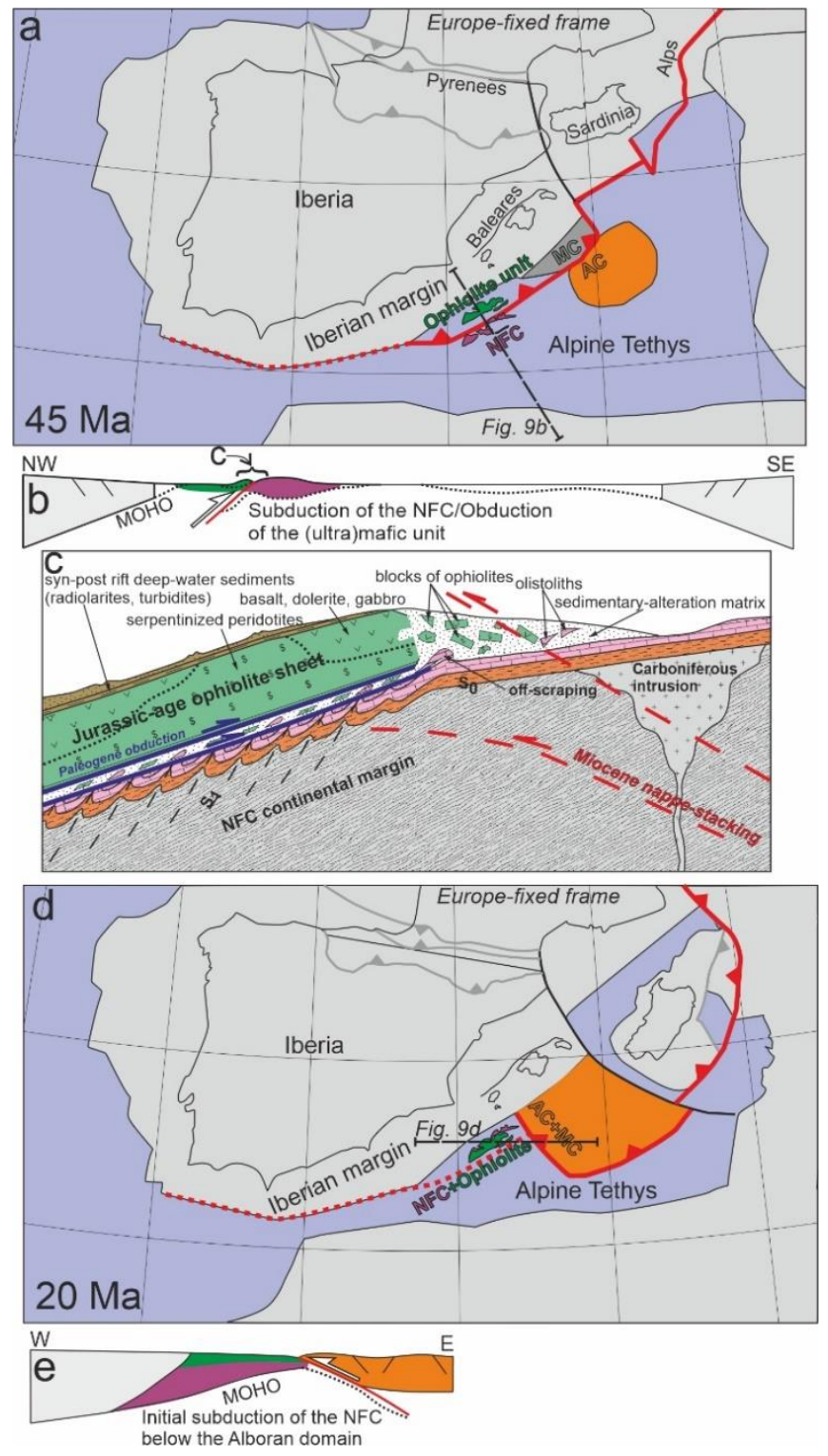

Figure 4.10. Tectonic reconstruction of the Western Mediterranean region highlighting the relevant tectonic units of the Betics, modified after van Hinsbergen et al. (2020) (a) Snapshot at 45 Ma showing the Paleogene subduction of the NFC and the AC below oceanic (Ophiolite unit) and continental (MC) upper plate segments, respectively. (b) Schematic cross-section through the $45 \mathrm{Ma}$ reconstruction snapshot. (c) Schematic sketch of the obduction process magnified from the cross-section of Figure b, highlighting the possible positions of different lithologies (mafic and ultramafic rocks capped by syn-post-rift sediments, ophiolitic mélange, and the downgoing continental formations) observed in the continental NFC and Ophiolite unit. (d) Snapshot at 20 Ma showing the initial Early Miocene subduction of the NFC below the Alboran domain containing the MC and the AC. (e) Schematic cross-section through the 20 Ma reconstruction snapshot. 


\subsubsection{Implications for tectonic reconstructions}

Reconstructions of the Betics orogen have placed the continental NFC either in the $\mathrm{AlKaPeCa}$ terrane (i.e. a pre-subduction microcontinent or extensional allochthon), to explain Paleogene burial ages (e.g. Vissers et al., 1995), or on the SE-Iberian margin, to explain Miocene burial ages (e.g. Platt et al., 2006). Based on the combination of our results and literature data (e.g. Figure 4.8), we suggest that these interpretations are not mutually exclusive, and we envisage a two-stage evolution for the NFC that contains both phases of burial.

The Paleogene burial ages of the continental NFC place these units within the $\mathrm{AlKaPeCa}$ terrane, which differs from recent paleogeographic reconstructions (e.g. van Hinsbergen et al., 2020; van Hinsbergen et al., 2014). The burial of the NFC and AC are simultaneous, and given the very low convergence rates of only $\mathrm{mm} / \mathrm{year}$ in the Eocene, this requires that the NFC and $\mathrm{AC}$ were lateral paleogeographic units that were both part of the $\mathrm{AlKaPeCa}$ terrane (part of the same continental block or laterally separated blocks, Figure 4.10a). The AC was buried below the MC that was presumably either the most distal forearc of Iberia, or a continental nappe that was also derived from the AlKaPeCa. There is no structurally higher unit above the MC to give a conclusive answer. The NFC was buried below oceanic crust (the Ophiolite unit), and we therefore envisage that the subduction zone transitioned from along the Iberian continental margin into the oceanic crust of the Alpine Tethys, such that a narrow strip of oceanic crust was located in the upper plate, below which the NFC subducted in Eocene time (Figures 4.10a, b, c).

The Miocene burial of the NFC plus the overlying ophiolites below the AC requires that the pivot point around which the trench rotated was located between the two units (Figure 4.10d). As a result, the NFC and the overlying Ophiolite unit were part of the Iberian margin (lower plate), whilst the AC was part of the upper plate, i.e the Alboran domain (Figures 4.10d, e). The Alboran domain started to thrust over the NFC and the Ophiolite unit in the Miocene, with an almost opposite vergence compared to Paleogene thrusting (Figures 4.10a, d). This Miocene history is the same as in van Hinsbergen et al. (2020). The difference is that instead of assuming an undeformed Iberian margin, our reconstruction implies that the Iberian margin already hosted an Eocene fold-thrust belt related to ophiolite obduction, prior to the Miocene subduction below the Alboran domain.

This model explains the two phases of burial in the NFC, corresponding to Paleogene and Miocene geochronological data, and only one, Paleogene phase of burial in the AC, while keeping the consistency with all other geological and geophysical data described in van Hinsbergen et al. (2020). It also explains the presence of an ophiolitic mélange associated with the (meta-)mafics and ultramafics of the Ophiolite Unit by incorporating Paleogene obduction (Figure 4.10c). The Paleogene obduction might also play an important role in the rheological weakening of the Iberian margin, which might be important for facilitating the westward rollback of the slab along the margin (Chertova et al., 2014). In our reconstrution, the NFC undergoes $\sim 25^{\circ}$ clockwise rotation following the Early Miocene subduction. As the initial Miocene burial direction was top-W (Figure 4.10d), the presently observed NW-SE orientation of the moderate-temperature stretching lineations are explained by the clockwise rotation (the originally E-W trending lineations are rotated to NW-SE). Furthermore, this rotation might also explain the observed top-SSW vergence in and above the ophiolitic 
mélange formation (Figure 4.5a, d): the Paleogene vergence of obduction was top-SE (Figure 4.10a), which rotates to a more southerly ( top S) direction after the Early Miocene.

\subsection{Conclusions}

We presented the results of a structural analysis and single grain fusion ${ }^{40} \mathrm{Ar} /{ }^{39} \mathrm{Ar}$ dating of white micas to address the paleogeographic and tectonic evolution of the Betics mountain range in SE Spain. We refined the tectonic subdivision of the eastern Sierra de los Filábres to document strain localization during the burial and exhumation of the NFC. Our results show that the main nappe contacts in the NFC were active during the Miocene continental subduction-exhumation cycle both at near-peak metamorphic conditions during the late burial stage and at retrograde conditions during the early exhumation stage of the NFC. The kinematics of shearing along the nappe contacts gradually changed from top-NNW to top-W as the rocks were being exhumed and captured by the top-W-WSW extensional detachment localized at the brittle-ductile transition zone. The observed change in the sense of shear during exhumation suggest that the extensional detachment obliquely cut the inherited nappe contacts, hence the low-grade formations exposed along the northern flank of the Sierra de los Filábres do not necessarily belong to the AC, but may also belong to the NFC in terms of paleogeographic provenance. We documented the existence of an ophiolitic mélange formation, which suggests that the (ultra)mafic succession of the NFC (Ophiolite unit) is a dismembered ophiolite sheet originally emplaced by an obduction process. White mica ${ }^{40} \mathrm{Ar} /{ }^{39} \mathrm{Ar}$ ages correlate with the preservation or obliteration of an early, relic, metamorphic fabric in the rocks of the NFC. Our white mica ${ }^{40} \mathrm{Ar} /{ }^{39} \mathrm{Ar}$ ages hence largely record Ar-loss due to deformation/fluid-induced recrystallization during two fabric-forming periods at 38$27 \mathrm{Ma}$ and 22-12 Ma. The combination of our results with previously published geochronological data in the NFC suggests a tectonic model with two phases of burial (subduction) in the Paleogene and subsequently in the Early-Middle Miocene. Our proposed tectonic reconstruction accounts for Paleogene obduction of the Ophiolite unit over the continental formations of the NFC, which explains Paleogene geochronological data in the NFC as well as the presence of an obduction mélange in the Ophiolite unit. 


\section{Chapter 5. Extrusion of subducted crust explains the emplacement of far-travelled ophiolites ${ }^{4}$}

${ }^{4}$ This chapter is based on Porkoláb, K., Duretz, T., Yamato, P., Auzemery, A., Willingshofer E., 2021, Nature Communications, 12, 1499. 


\subsection{Introduction}

Finding physical mechanisms that explain how dense oceanic lithosphere, referred to as ophiolite, is emplaced on top of lighter continental plates (i.e. obduction) has prompted a long-standing scientific discussion(Agard et al., 2014; Coleman, 1971; Dewey, 1976). Ophiolites may be accreted to continents by being scraped off from the subducting oceanic lower plate (Coleman, 1971; Oxburgh, 1972), or emplaced on top of the continent in a continental lower plate - oceanic upper plate subduction setting (Boudier et al., 1988; Duretz et al., 2016a). In the latter case, subduction typically initiates within the ocean resulting in the formation of high temperature-low/medium pressure (HT-LP/MP) metamorphic soles at the base of the upper plate (Agard et al., 2016; van Hinsbergen et al., 2015). Intra-oceanic subduction is followed by continental subduction below the oceanic upper plate when the continental margin enters the subduction zone. Such ophiolite belts exhibit high pressure-low temperature $(H P-L T)$ metamorphic units structurally underlying the ophiolite (Figures 5.1 a, $\mathrm{b}, \mathrm{c})$. These $H P-L T$ units predominantly consist of continental upper crust that represents the former passive margin of the subducting continent (Kilias et al., 2010; van Hinsbergen et al., 2016; Yamato et al., 2007). The subduction and exhumation of these units appear to be a relatively short-lived process, as evidenced by the characteristic duration of 10-30 Myr for the subduction-exhumation cycle recorded in the metamorphic rocks (Figure 5.1e). The exhumed continental units are typically found between an ophiolite sheet that was transported for tens or even hundreds of kilometers over the continent (far-travelled ophiolite sheets) and the rest of the oceanic domain (open ocean or suture zone of the former ocean) (Figures 5.1a, b). Far-travelled ophiolite sheets are up to $10 \mathrm{~km}$ thick, and their average width is $50-55 \mathrm{~km}$ (Figure 5.1e), suggesting that their dimensions are mechanically limited during emplacement. 
a Oman

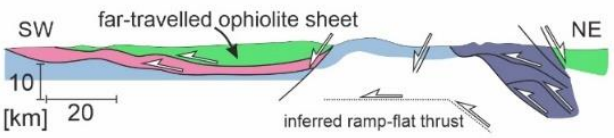

b New Caledonia
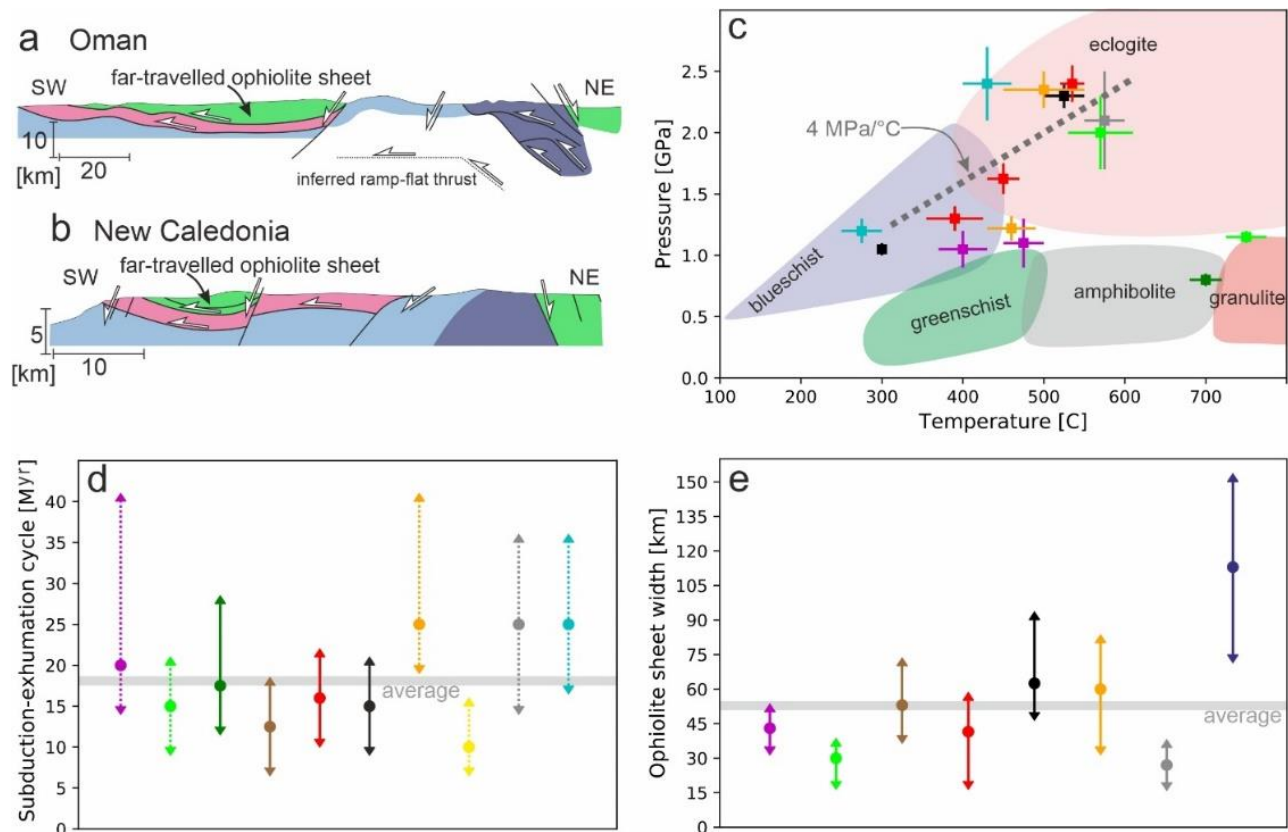

Legend for cross sections (a, b)

$\square$ oceanic lithosphere

non-metamorphic sediments

accreted to the oceanic upper plate

non-metamorphic to medium-grade

(HP-LT) continental crust

medium to high-grade (HP-LT)

Legend for data plots (c, d, e)

Brooks Range

Cuba

Kirşehir block (NE-Anatolia)

Lesser Caucasus

continental crust

Figure 5.1. Datasets collected from natural ophiolite belts. For detailed explanation and references regarding the datasets (c, d, e) see Supplementary Note 1 and Supplementary Tables 5.1, 5.2. Simplified cross sections showing the structure of the Oman (Searle, 2007) (a) and New Caledonia (Maurizot et al., 2020; Patriat et al., 2018) (b) ophiolites and their structural relationship to the underlying continental rocks. The far-travelled ophiolite sheets are separated from their oceanic root by exhumed continental units, which show a transition from non-metamorphic to high metamorphic grade. (c) Peak pressure-temperature $(P-T)$ data collected from the subducted and exhumed geological units in natural ophiolite belts. Multiple data points from the same location represent the peak conditions of different structural levels. Error bars represent the uncertainty of thermodynamic calculations. (d) Duration of the continental subductionexhumation cycle below the oceanic upper plate as recorded by the buried and exhumed continental formations. The duration is calculated from the arrival of the continental margin in the subduction zone to the near surface/surface exhumation of the subducted formations and is indicated by colored circles. Error bars show uncertainties associated with the duration of the subduction-exhumation cycle, where solid lines reflect well-constrained and dotted lines poorly constrained cases, respectively (see Supplementary Note 1). e Average width of far-travelled ophiolite sheets (colored circles) and the deviation from the average along strike (error bars) in natural ophiolite belts. The width was measured along 3-8 cross sections along each ophiolite belt.

Models of ophiolite emplacement hence have to account for 1) short-lived continental subduction below the oceanic upper plate followed by exhumation of the subducted upper crust, and 2) the observed dimensions of ophiolite sheets. Recent numerical modelling studies 
achieved these conditions by imposing convergence to reach the state of continental subduction, and subsequently imposing divergence to exhume the continental margin and thin the oceanic upper plate (Duretz et al., 2016a; Hässig et al., 2016). However, these models do not lead to nappe formation in the subducted continental crust, which is a key feature of natural systems and seems to play an important role in the exhumation of the HP-LT continental rocks (Kilias et al., 2010; Pourteau et al., 2013; Searle, 2007). Moreover, stacking of continental nappes below the oceanic upper plate is critical for inducing uplift on top of the rising thrust sheet(s), which in turn may lead to gravity-driven extension in the upper plate (Agard et al., 2010; Chemenda et al., 1996; Lagabrielle et al., 2013). Extension in the upper plate might significantly contribute to the unroofing of the subducted continental rocks as well as in separating the far-travelled ophiolite sheet from its root (Chemenda et al., 1996; Lagabrielle et al., 2013). Hence, exploring decoupling and nappe formation mechanisms in the continental lower plate is crucial to understanding the deformation of the oceanic upper plate and far-travelled ophiolite emplacement.

Here, we combine numerical thermo-mechanical simulations of oceanic upper platecontinental lower plate subduction systems and data acquired in ophiolite belts worldwide to unravel the physical processes that explain the structure of ophiolite belts. We highlight the genetic link between the extrusion of the subducted continental crust and the emplacement of far-travelled ophiolite sheets, and further identify the key parameters controlling this process.

\subsection{Results}

\subsubsection{Modelling strategy}

We designed 2D thermo-mechanical numerical simulations governed by momentum, mass, and heat conservation equations and a visco-elasto-plastic rheological model (see Methods for details of numerical modeling techniques and further model setup description). A total plate convergence velocity of $3 \mathrm{~cm} / \mathrm{yr}$ is achieved by prescribing constant normal inflow velocities of $\left|\mathbf{V}_{\text {in }}\right|=1.5 \mathrm{~cm} / \mathrm{yr}$ along the upper $140 \mathrm{~km}$ of the two model sides. Mass conservation is satisfied by gradually increasing outflow below $140 \mathrm{~km}$ (Figure 5.2a). A convergence velocity test was performed to explore the role of this parameter (Supplementary Note 5.2, Supplementary Figure 5.1). The top boundary of the model is a true free surface (Duretz et al., 2016b). The initial model geometry is inspired by reconstructions of preobduction geodynamic settings where intra-oceanic subduction is initiated relatively close $(<$ $400 \mathrm{~km}$ ) to the continental passive margin, which arrives to the subduction zone after $\sim 10$ Myr of oceanic subduction (Maffione and van Hinsbergen, 2018; Maffione et al., 2017; Searle and Cox, 1999). Subduction is designed to initiate along an inclined weak zone (equivalent to an oceanic detachment) close to the mid-ocean ridge to achieve a right-dipping subduction zone and a thermally young ophiolite front, in agreement with natural ophiolite belts (Maffione et al., 2015). A simplified continental passive margin geometry is implemented by linearly decreasing crustal thickness over the distance of $200 \mathrm{~km}$ (Figure 5.2a). The continental basement is divided in two parts (upper and lower crust) constituted of different materials (Tables 5.1, 5.2), which introduces a decoupling level at the base of the 
upper crust (Figure 5.2a). A resolution test was performed to verify the robustness of the model results (Supplementary Figure 5.2).

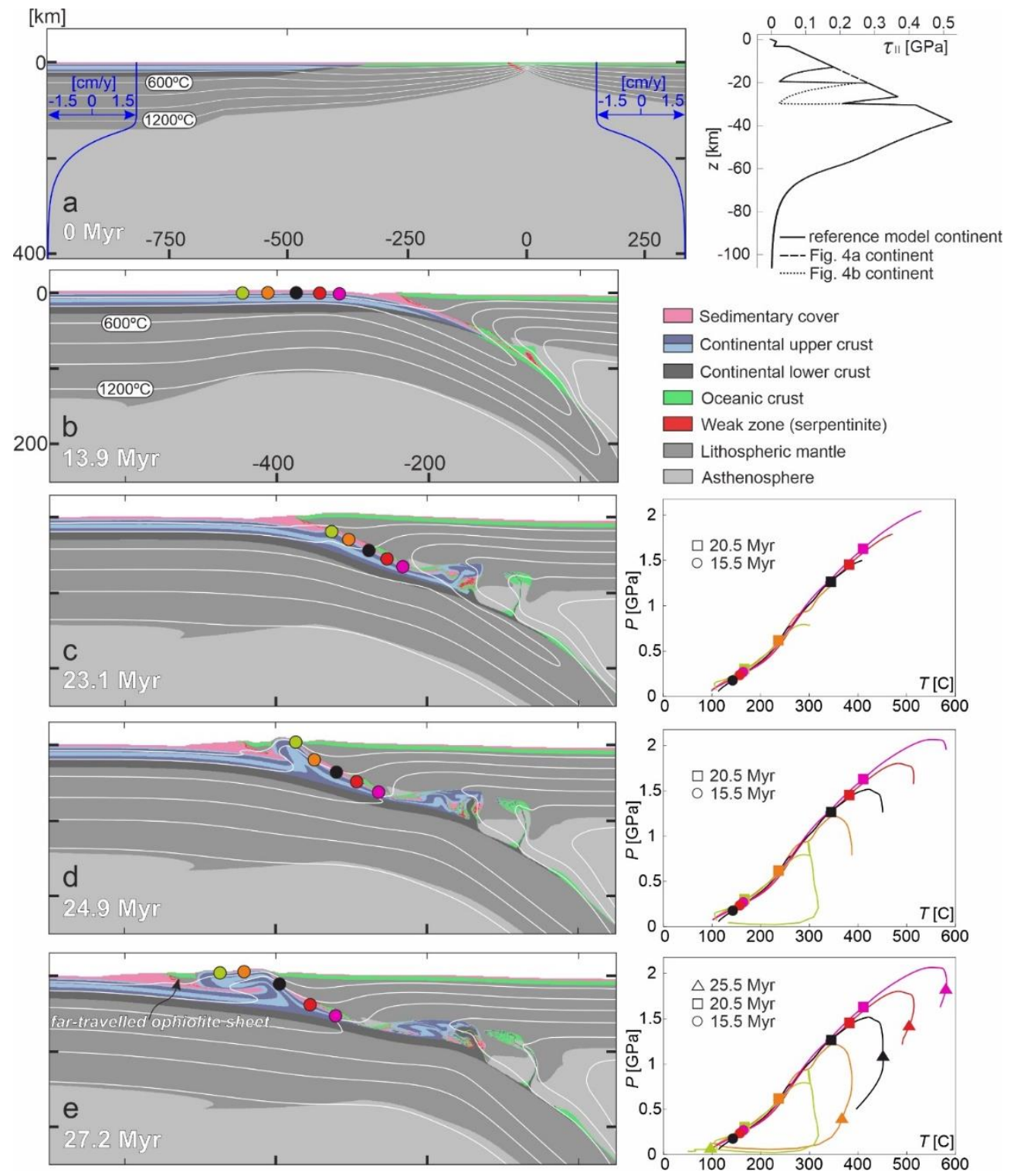

Figure 5.2. Model setup and evolution of the reference model. The compositional evolution and associated $P-T$ paths are presented in Figures b-e on the left and right side, respectively. Colored circles are the positions of selected particles for recording $P-T$ conditions and correspond to the colored lines on the left-side $P$ - $T$ diagrams. (a) Model setup showing the initial distribution of compositional domains, the velocity boundary condition, and the strength profile (second stress invariant vs depth, assuming a transcurrent setting) for the continental domain. For thermal and rheological parameters of the model compositions see Table 5.1. Layering in the continental upper crust corresponds to passive strain markers. White lines are isotherms from 200 to $1200{ }^{\circ} \mathrm{C}$. (b) Early-stage continental subduction at 13.9 Myr after the subduction of the left-side ocean between 
0 and 10 Myr. (c) Late-stage continental subduction after the initiation of upper crustal decoupling. (d) Breaking of the oceanic upper plate and accelerated extrusion of the subducted upper crust. (e) Emplacement of the far-travelled ophiolite sheet further leftwards on top of the continent, dictated by crustal extrusion.

\subsubsection{General evolution of the reference model}

Intra-oceanic subduction initiation is followed by the subduction of oceanic lithosphere until 10 Myr. The passive margin of the continent then starts to subduct below the oceanic upper plate (i.e. obduction; Figure 5.2b), and experiences HP-LT metamorphism up to eclogite facies $P-T$ conditions (Figure 5.2c). The $3 \mathrm{~km}$ thick sedimentary cover of the passive margin partially subducts with the rest of the continental lithosphere, but is largely stacked and accreted to the front of the oceanic upper plate (Figure 5.2). After reaching eclogite facies conditions, the burial velocity of the upper crust decreases from $\sim 3 \mathrm{~cm} / \mathrm{yr}$ at $18 \mathrm{Myr}$ to near zero at $23 \mathrm{Myr}$. This is the moment when the upper crust starts to decouple from the lower crust and the lithospheric mantle. Decoupling results in the localization of a major reversesense shear zone along which the subducted upper crust is extruded upwards and leftwards (Figure 5.2d). The oceanic upper plate undergoes gravity-driven extension when being pushed up by the extruding thrust sheet. Extension leads to the breaking of the oceanic upper plate, which enables the continental upper crust to be rapidly extruded to the surface, separating a $50 \mathrm{~km}$ wide and maximum $13 \mathrm{~km}$ thick far-travelled ophiolite sheet from the rest of the oceanic lithosphere (Figures 5.2d, e). 


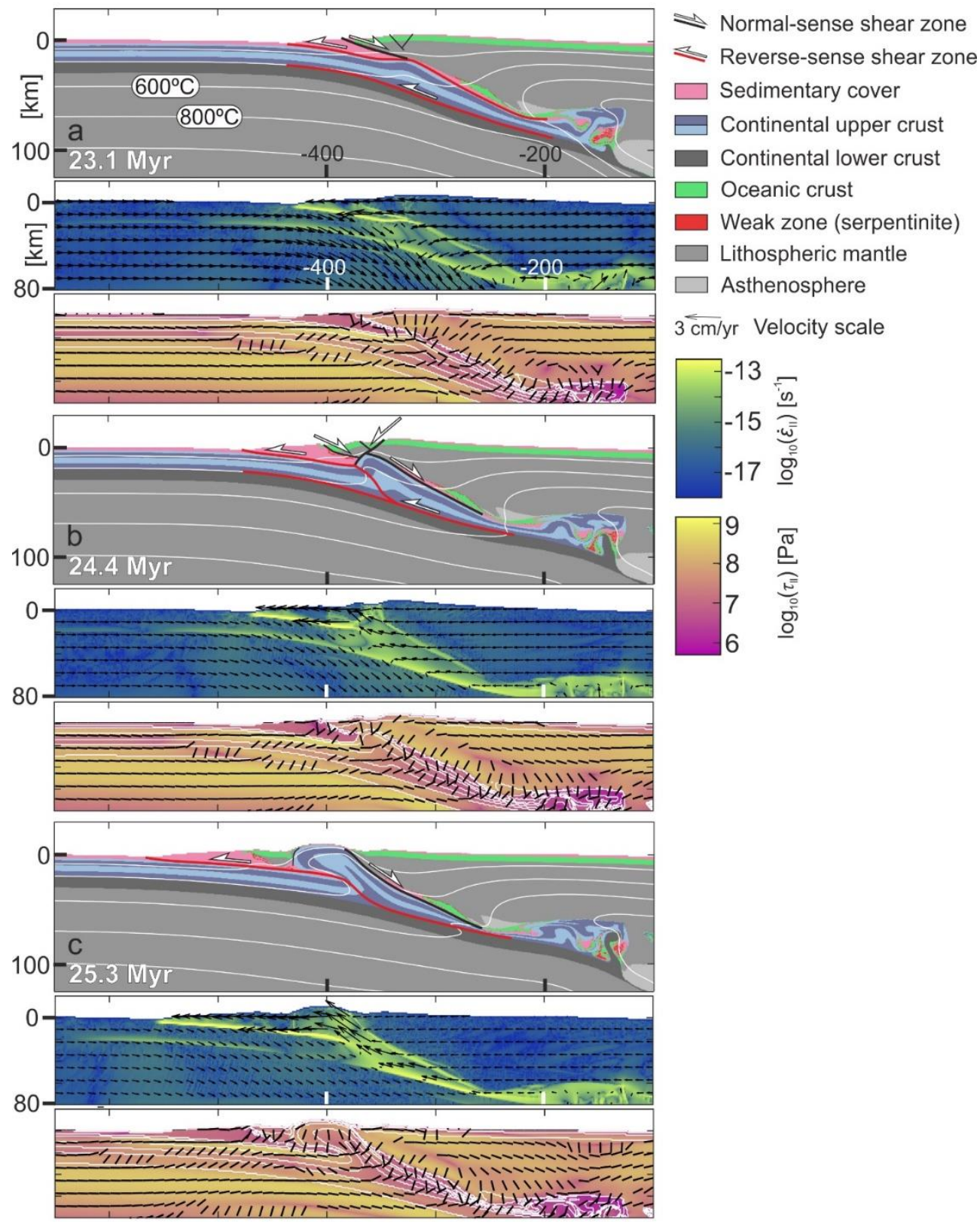

Figure 5.3. Kinematic and dynamic evolution of continental upper crust extrusion and upper plate necking. Top panels show the compositional domains with the interpreted main structures (shear bands in the brittle domain are interpreted as faults), the middle panels provide information of the strain rate with velocity arrows, while the bottom panels on the second stress invariant with the orientation of the most compressive principal stress $\left(\sigma_{1}\right)$. The color fill of the middle and bottom panels are based on scientific colormaps (Crameri, 2018). The orientations of $\boldsymbol{\sigma}_{\mathbf{1}}$ on bottom panels are shown by black lines, horizontal for compression, vertical for extension. The boundaries of different compositional domains presented on the top panels are highlighted with 
white contour lines on the lower right panels. (a) Decoupling of the upper crust and initiation of upper plate extension. (b) Further localization of main thrust and extensional accommodation structures that break the upper plate. (c) Emplacement of far-travelled ophiolite sheet by further crustal extrusion.

\subsubsection{Ductile nappe formation: the onset of exhumation}

Burial of continental crust below a denser oceanic plate leads to a progressive increase of the buoyancy force that resists subduction despite the continuously imposed plate convergence. From $21 \mathrm{Myr}$ (i.e. after $11 \mathrm{Myr}$ of continental subduction) the velocity of the subducting continental upper crust becomes near zero, while the lower crust and the lithospheric mantle still subduct at $\sim 1.5 \mathrm{~cm} / \mathrm{yr}$ (Figure 5.3a). This kinematic setting leads to an increase of deviatoric stress within the lower crust, which meets the conditions for strain localization by thermal softening (Kiss et al., 2019). As a result, a major reverse-sense shear zone develops and exhibits strain rates of $>10^{-13} \mathrm{~s}^{-1}$ (Figure 5.3a). The shear zone is initially low-angle, and propagates along the base of the upper crust, which is the weakest horizon in the continental crust (Figures 5.2a, 5.3a). The shear zone thus facilitates decoupling between the crustal layers, which is further accommodated by distributed deformation (folding) at a strain rate of $\sim 10^{-14} \mathrm{~s}^{-1}$ in the entire subducted upper crust.

\subsubsection{Interplay between crustal extrusion and upper plate necking}

Upper crustal decoupling and nappe formation results in uplift, which triggers extension of the oceanic upper plate over a $50 \mathrm{~km}$ wide zone (Figure 5.3a). Extension leads to the formation of normal faults and to the normal-sense reactivation of the original plate boundary thrust (Figure 5.3a).

Further strain localization results in the connection of the two flat reverse-sense shear zone segments by a steeper ramp segment. This structure separates very-low-grade to nonmetamorphic upper crust from the low-grade to eclogite-facies upper crust (Figure 5.3b). The localization of the main shear zone facilitates the acceleration of upper crustal extrusion (from $0.5-1 \mathrm{~cm} / \mathrm{yr}$ until 24.5 Myr to $1.5-3 \mathrm{~cm} / \mathrm{yr}$ from $25 \mathrm{Myr}$ ), which is accommodated by increasing displacement along the right-and left-dipping extensional shear zones and leads to the necking of the oceanic upper plate (Figures 5.3b, c). Through this process a sheet of oceanic lithosphere (the future far-travelled ophiolite) gets disconnected from the oceanic plate along the left-dipping normal fault, which joins the upper flat segment of the main thrust in depth (Figure 5.3b). Subsequently, the far-travelled ophiolite sheet is emplaced on top of the continent and transported to the left along the upper flat thrust segment (Figure 5.3c). This process is driven by the progressive extrusion of the continental crust. 

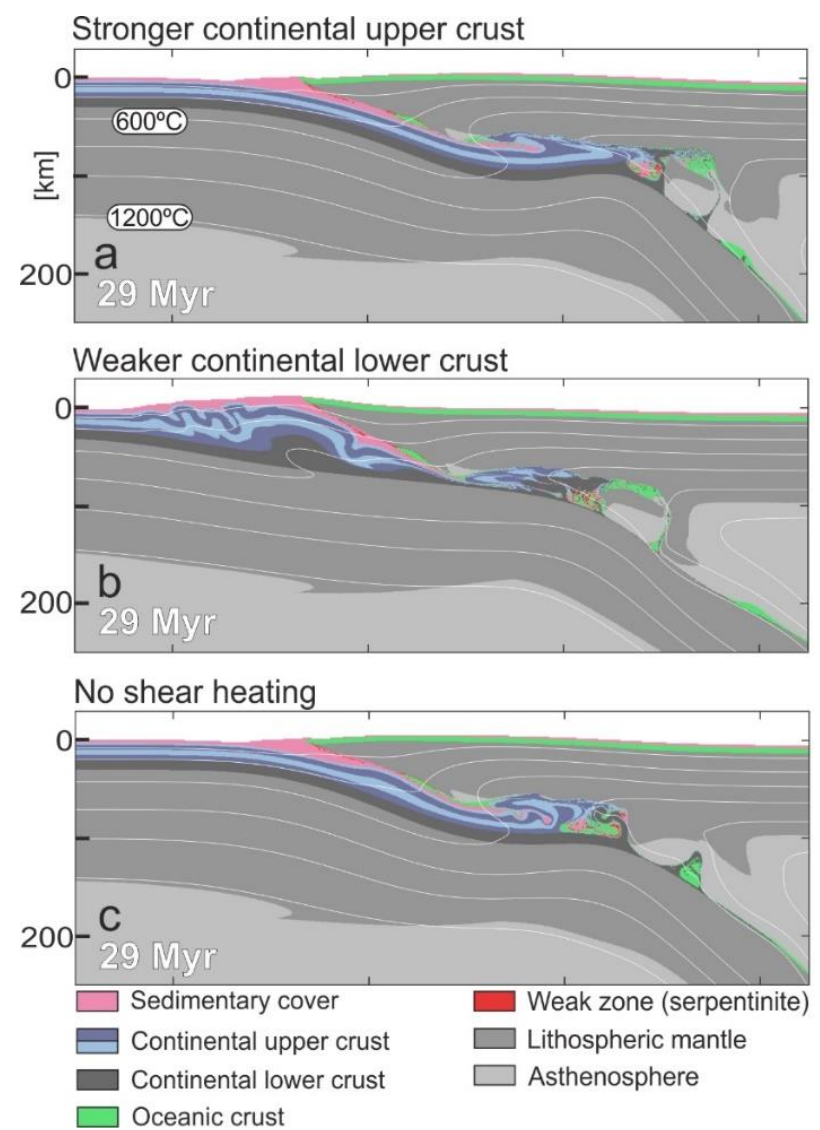

Figure 5.4. Effects of changing key parameters compared to the reference model setup. (a) Model compositions at 29 Myr with stronger upper crust rheology (Maryland diabase instead of Westerly granite) (Carter and Tsenn, 1987; Hansen and Carter, 1983). For the initial strength profile of the continental domain see Figure 5.2a. (b) Model compositions at $29 \mathrm{Myr}$ with weaker lower crust rheology (Maryland diabase instead of mafic granulite) (Carter and Tsenn, 1987; Ranalli, 1995). For the initial strength profile of the continental domain see Figure 5.2a. (c) Model compositional domains at 29 Myr with shear heating switched off.

\subsubsection{Key parameters controlling crustal extrusion and far-travelled ophiolite emplacement}

Extensive tests have been performed on the reference model to determine key parameters that control the extrusion of the upper crustal thrust sheet, which is instrumental for the necking of the upper plate and the emplacement of far-travelled ophiolite sheets (Figure 5.4). In particular, we evaluated the impact of the crustal rheology of the subducting plate and shear heating on the process of nappe formation.

In the reference model, a decoupled crustal rheology is achieved by using the Westerly granite flow law (Hansen and Carter, 1983) for the continental upper crust, and a mafic granulite flow law (Ranalli, 1995) for the lower crust (Figure 5.2a). Using a stronger 
Maryland diabase flow law (Carter and Tsenn, 1987) for the upper crust results in a more coupled, stronger crustal rheology (Figure 5.2a). This prevents upper crustal decoupling after reaching eclogite-facies conditions and inhibits subsequent nappe formation and extrusion (Figure 5.4a). Instead, the upper crust is subducted to greater depth and enhanced underplating occurs compared to the reference model.

A more coupled, but relatively weak crustal rheology can be achieved by decreasing the strength of the continental lower crust (Figures 5.2a, 5.4b). Such a rheology results in the decoupling of the entire continental crust from the lithospheric mantle rather than the decoupling of the upper crust from the lower crust (Figure 5.4b). This leads to distributed folding and thrusting in the lower plate rather than localized nappe formation and extrusion of the subducted upper crust. Our results thus indicate that both strong (Figure 5.4a) and weak (Figure 5.4b) coupled crustal rheologies inhibit upper crustal extrusion and associated the emplacement of far-travelled ophiolites. We further tested different types of decoupled crustal rheological models to determine the effect of smaller compositional or thermal differences. The results show that slight variations in the thermal and material properties lead to different timing and thus position of crustal decoupling, which is reflected in different amounts of underplated continental upper crust below the oceanic upper plate (Supplementary Figure 5.3). Rheology and coupling of the continental crust hence are key factors that control nappe formation, upper crust extrusion and upper plate necking.
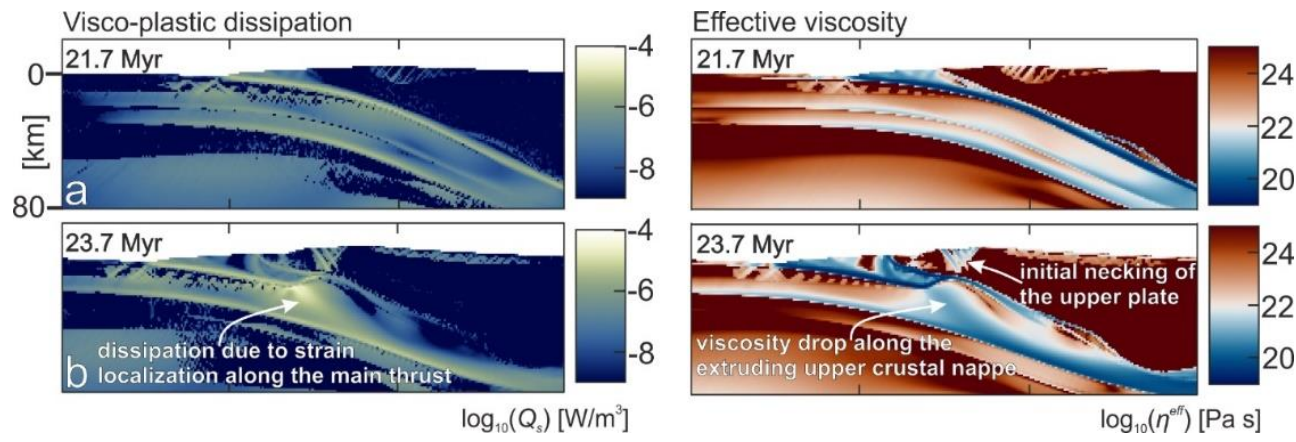

Figure 5.5. The effect of shear heating. (a) Plot of visco-plastic dissipation of mechanical energy in the form of heat $\left(Q_{\mathrm{s}}\right)$ (left panel) and effective viscosity ( $\eta^{\text {eff }}$, right panel) at the $21.6 \mathrm{Myr}$ snapshot of the reference model, prior to nappe formation in the subducting continental crust. (b) Plots of visco-plastic dissipation of mechanical energy in the form of heat (left panel) and effective viscosity (right panel) at the $23.7 \mathrm{Myr}$ snapshot of the reference model, after nappe formation at in the subducted continental crust. Color fills of the plots are based on scientific colormaps(Crameri, 2018).

The degree of coupling in the subducting continental crust is also affected by shear heating, a process that dissipates mechanical energy in the form of heat, facilitating shear zone formation in the lithosphere (Duretz et al., 2015; Kiss et al., 2019). In our reference model shear heating results in heat production that can be up to two orders of magnitude larger than the average radiogenic heat production in the continental crust (Figure 5.5b, see Table 5.1 for radiogenic heat production $\left(Q_{\mathrm{r}}\right)$ values). This effect is transient and has limited spatial extent, but it induces thermal softening of the ductile material and may trigger the formation of a shear zone. This is documented by a reduction of the effective viscosity at the base of the incipient nappe at the boundary of the lower and upper continental crust and 
further along the steeper ramp section (Figure 5.5). This allows an upper crustal nappe to decouple from the rest of the subducting lithosphere and extrude upwards and leftwards along the shear zone (Figures 5.3b, 5.5). The model which does not include shear heating (Figure 5.4c) shows that strain localization and nappe formation fails to initiate, or is significantly delayed compared to the reference model (Figure 5.3). Without shear heating, the coupling between the upper crust and the subducting lithosphere is too high to allow for nappe formation and its subsequent extrusion. Instead, buoyancy force leads to the underplating of the subducted upper crust. This demonstrates that shear heating is essential for strain localization and nappe formation in our reference model.

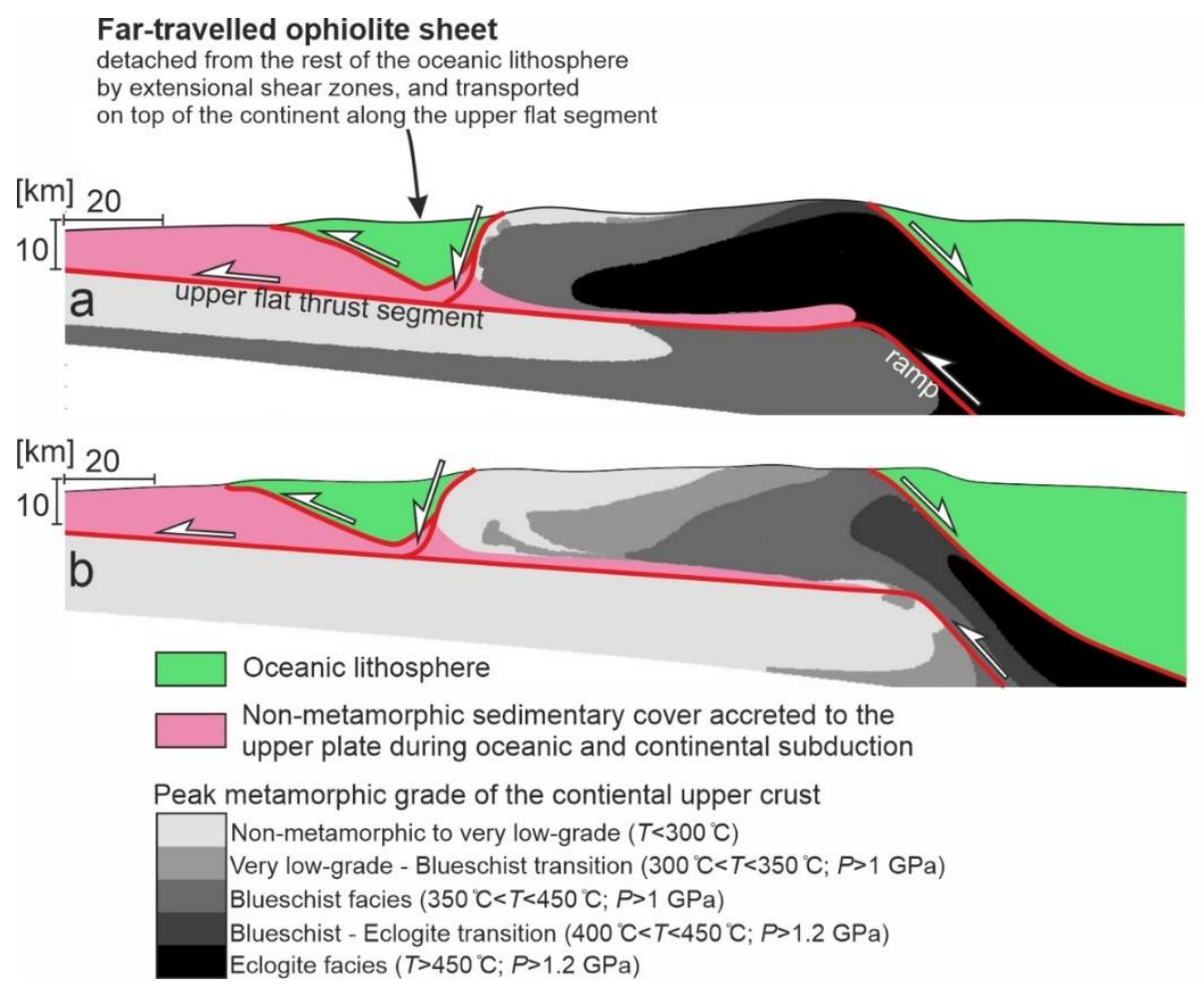

Figure 5.6. Near-surface composition and structure of final model snapshots. The peak metamorphic zonation of the exhumed continental upper crust is plotted for (a) the reference model and (b) the Mod 1 model variant (for model parameters see Table 5.2, for initial strength profile see Supplementary Fig. 3). The panels are a combination of calculated metamorphic domains for the continental upper crust, compositional domains for the sedimentary cover and the oceanic lithosphere, and line interpretations of the main shear zones. The peak metamorphic zones are defined based on the recorded maximum pressure $(P)$ and temperature $(T)$ values of the upper crustal particles throughout the entire model evolution, and hence represent the theoretical maximum metamorphic grade reached by the given crustal domains. In both cases, a transition from non-metamorphic to eclogite-grade metamorphic rocks are observed within the upper crustal tectonic window. The reference model (Figure 5.6a) has a higher initial continental geothermal gradient $\left(T_{\mathrm{MOHO}}=510{ }^{\circ} \mathrm{C}\right)$, therefore it shows higher peak metamorphic grades compared to the model (Mod 1) with colder Moho temperature $\left(T_{\mathrm{MOHO}}=375^{\circ} \mathrm{C}\right)$ (Figure 5.6b). 


\subsection{Comparison to natural ophiolite belts}

Our models display many first-order features of natural ophiolite belts that are related to continental subduction below an oceanic upper plate (Figure 5.6). It produces a fartravelled ophiolite sheet as the structurally highest unit, separated from its root by buried and then exhumed HP-LT continental rocks, and underlain by accreted non-metamorphic to lowgrade sedimentary cover units (Figures 5.1a, 5.1b and 5.6). The tectonic window of exhumed continental crust shows a gradual decrease in metamorphic grade from blueschist-eclogite facies to non-metamorphic towards the far-travelled ophiolite sheet (Figure 5.6). The reference model has a relatively warm initial continental geotherm $\left(T_{\mathrm{MOHO}}=510{ }^{\circ} \mathrm{C}\right)$, and therefore shows higher peak metamorphic grades than the Mod 1 variant, which has an initially colder continent $\left(T_{\mathrm{MOHO}}=375^{\circ} \mathrm{C}\right)$ (Figures 5.6a and b, respectively). As such, the reference model closer resembles natural sites where the tectonic window largely consists of metamorphosed crust. Such a case is observed in New Caledonia or Western-Central Anatolia, where the majority of the exposed continental crust reached $P>1 \mathrm{GPa}$ and $T$ between 300 and $600{ }^{\circ} \mathrm{C}$ (Brovarone and Agard, 2013; Okay, 2002; Potel et al., 2006; Pourteau et al., 2013). On the other hand, Mod 1 fits better to natural examples where large fractions of the tectonic window exhibit no or very low-grade metamorphic overprint, with relatively minor volumes of high- $T$ blueschist and eclogite facies rocks (e.g. the Oman or Lesser Caucasus ophiolite belts (Hässig et al., 2016; Searle et al., 2004)). In both cases, the highest-grade continental rocks are separated from the oceanic lithosphere to the right by a major normal-sense shear zone that accommodated the extrusion of the subducted continental crust (Figure 5.6). The ophiolite sheet and the underlying accreted sedimentary units are resting on the upper flat thrust segment of the main shear zone system that further transported the upper plate units (far-travelled ophiolite sheet and accreted sediments) leftwards during the extrusion of the continental crust. The normal-sense shear zone that separated the fartravelled ophiolite sheet from its root during the extrusion joins this upper flat thrust segment. The prograde $P-T$ ratio and peak $P-T$ conditions recorded by the deeper parts of the subducted upper crust in our reference model $\left(4 \mathrm{MPa} /{ }^{\circ} \mathrm{C}\right.$ and $\sim 2 \mathrm{GPa}$ at $500-600{ }^{\circ} \mathrm{C}$, respectively) are average values compared to those of natural cases (Figures 5.1c, 5.2d, Supplementary Table 5.1). The duration of the continental subduction-exhumation cycle (15-20 Myr) is in agreement with the well-constrained ophiolite belts like Oman or New Caledonia, and appears to be slightly shorter than the sites where subduction and/or exhumation of the continental formations is poorly dated or debated (e.g. Brooks Range, Hellenides-Dinarides, Southern Ural; see Figure 5.1e, Supplementary Note 1, Supplementary Table 5.2). Observations such as post-subduction ductile to brittle extensional deformation (Rawling and Lister, 2002; Searle, 2007), or the coexistence of opposite shear sense directions in the former passive margin units (Porkoláb et al., 2019b; van Hinsbergen et al., 2016) fit well with the structural evolution of our model, which involves top-left shearing (thrusting) during burial and both top-left and top-right shearing during exhumation (normal faulting) (Figures 5.3, 5.6). The width of the far-travelled ophiolite sheet $(50 \mathrm{~km})$ predicted by the model $(\mathrm{s})$ agrees very well with the average width $(53 \mathrm{~km})$ of natural ophiolite belts (Figure 5.1e, Supplementary Note 1).

Hence, the structure, dimensions, composition, and P-T-t conditions of our model closely resemble those of natural ophiolite belts. The geometry and time evolution of our 
model also allows comparison with the currently active continental subduction of the Australian continental margin below the oceanic Banda arc. The Australian continental margin has been subducting for $\sim 10 \mathrm{Myr}$ (Keep and Haig, 2010), which roughly equals the duration of upper crustal subduction in our reference model. Reconstruction of the stacked and accreted sedimentary cover shows that $215-230 \mathrm{~km}$ of continental lithosphere has been subducted, but only the uppermost $2 \mathrm{~km}$ of sedimentary cover was accreted to the upper plate (Tate et al., 2015). Hence the present-day structure and dimensions of the Australian continental subduction are very similar to those of our reference model in the 20-23 Myr snapshots (Figure 5.2c).

\subsection{Discussion}

Our results have important implications for the dynamics of ophiolite emplacement in oceanic upper plate-continental lower plate subduction systems, and thus may be widely applied to understand geological observations in natural ophiolite belts. While plate kinematic changes may play an important role in initiating intra-oceanic subduction (Agard et al., 2007), or in the cessation of contraction at continental subduction zones (Duretz et al., 2016a), we show that the emplacement of far-travelled ophiolite sheets can result from synconvergence, buoyancy-driven decoupling and upward extrusion of the subducted continental upper crust accommodated by the necking of the oceanic upper plate. Crustal extrusion and the resulting necking of the upper plate in our model are consistent with cases studies from Oman (Chemenda et al., 1996) and New Caledonia (Lagabrielle et al., 2013). Extrusion of the subducted upper crust requires nappe formation. In agreement with previous studies (Duretz et al., 2015; Kiss et al., 2019), the results show that shear heating is an important mechanism that facilitates strain localization and nappe formation. The precise reproduction of smaller scale nappes (nappe thickness of several kilometers) which is often observed in case of continental subduction (Kilias et al., 2010; Searle, 2007) would require very high-resolution numerical modeling and built-in heterogeneities inside the upper crust to localize shear zones at multiple horizons (Duretz et al., 2016c; Kiss et al., 2020; Reuber et al., 2016). Our results also indicate that crustal decoupling and exhumation may take place with different timing and position in the subducted continent depending on the rheology of the continental crust (Vogt et al., 2017; Willingshofer et al., 2013). Variations in thermal or compositional properties thus might control the surface preservation (exhumation) or the subduction and recycling of different types of continental passive margins (e.g. magmatic or magma-poor passive margins) (Franke, 2013; Tugend et al., 2020; Yamato et al., 2008).

Numerous natural ophiolites show evidence for supra-subduction zone magmatism in the upper plate following intra-oceanic subduction initiation, which results in thermally younger, thus thinner upper plates (Meffre et al., 1996; Pearce et al., 1984; Tamura and Arai, 2006; van Hinsbergen et al., 2015). Our model does not account for such effects and hence may overestimate upper-plate thickness. Thinner upper plates would result in flatter continental subduction, which may lead to crustal decoupling and upper plate necking further away from the ophiolite front. If so, the size of the resulting far-travelled ophiolite sheets would be comparable to the widest far-travelled ophiolite sheets in Oman and Anatolia (80$150 \mathrm{~km}$ ) (see Supplementary Note 1). 
The current subduction of the Australian plate below the oceanic Banda arc provides an exciting example for a prospective future ophiolite belt. As more than $200 \mathrm{~km}$ of continental crust has already subducted below the oceanic plate (Tate et al., 2015), it most likely has reached eclogite facies conditions. Based on our model, decoupling of the Australian upper crust has already begun, or will begin in the geological near future. If decoupling is followed by nappe formation, the extrusion of the upper crust and simultaneous necking of the oceanic upper plate may lead to the emplacement of far-travelled ophiolites.

\subsection{Methods}

\subsubsection{Numerical modelling}

The above-presented modeling results were obtained by solving the coupled set of nonlinear thermo-mechanical equations. The steady state momentum equation, the heat transfer equation and the incompressible mass conservation equations are formulated as:

$$
\begin{gathered}
\frac{\partial \boldsymbol{\tau}_{i j}}{\partial x_{j}}-\frac{\partial P}{\partial x_{i}}=-\rho \mathbf{g}_{i} \\
\rho c_{p} \frac{D T}{D t}=\frac{\partial}{\partial x_{i}}\left(k \frac{\partial T}{\partial x_{i}}\right)+Q_{r}+Q_{s} \\
\frac{\partial \mathbf{v}_{i}}{\partial x_{i}}=0
\end{gathered}
$$

where $\mathbf{v}$ is the velocity vector, $T$ is the temperature, $k$ is the thermal conductivity, $\rho$ is the density, $c_{p}$ is the heat capacity at constant pressure, $Q_{r}$ is the radiogenic heat production, $\tau$ is the deviatoric stress tensor, $\dot{\varepsilon}$ is the deviatoric strain rate tensor, $P$ is the pressure and $\mathbf{g}$ is the gravity acceleration vector. The visco-plastic dissipation or shear heating, $Q_{s}$, is expressed as:

$$
Q_{s}=\boldsymbol{\tau}_{i j}\left(\dot{\boldsymbol{\varepsilon}}_{i j}-\dot{\boldsymbol{\varepsilon}}_{i j}^{\mathrm{e}}\right)
$$

where $\dot{\boldsymbol{\varepsilon}}_{i j}^{\mathrm{e}}$ the elastic portion of the deviatoric strain rate.

The density field evolves according the following equation of state:

$$
\rho=\rho_{0}\left(1-\alpha\left(T-T_{0}\right)\right)\left(1+\beta\left(P-P_{0}\right)\right)
$$

where $\rho_{0}$ is the reference density, $\alpha$ is the thermal expansivity, $\beta$ is the compressibility, $T_{0}$ and $P_{0}$ are the reference temperature and pressure which were respectively set to $0{ }^{\circ} \mathrm{C}$ and $10^{5} \mathrm{~Pa}$. We use the Boussinesq approximation; hence both density changes in the mass conservation equation and adiabatic heating are neglected.

The effective viscosity $(\eta)$ relates to the deviator stress and strain rate tensor:

$$
\boldsymbol{\tau}_{i j}=2 \eta \dot{\boldsymbol{\epsilon}}_{i j}=\left(\frac{1}{\eta^{v}}+\frac{1}{\eta^{e}}+\frac{1}{\eta^{p}}\right)^{-1} \dot{\boldsymbol{\epsilon}}_{i j}
$$

using a visco-elasto-plastic rheological model:

$$
\dot{\boldsymbol{\varepsilon}}_{i j}=\dot{\boldsymbol{\varepsilon}}_{i j}^{\mathrm{V}}+\dot{\boldsymbol{\varepsilon}}_{i j}^{\mathrm{e}}+\dot{\boldsymbol{\varepsilon}}_{i j}^{\mathrm{p}} \text { where } \dot{\boldsymbol{\varepsilon}}_{i j}^{\mathrm{V}}=\dot{\boldsymbol{\varepsilon}}_{i j}^{\mathrm{dis}}+\dot{\boldsymbol{\varepsilon}}_{i j}^{\text {Peierls }}
$$


where the v, e, and p superscripts stand for viscous, elastic and plastic and the superscripts dis and Peierls correspond to dislocation and Peierls creep mechanisms.

The viscous strain rate account for contributions of both Peierls and dislocation creep. The contribution of dislocation creep is expressed as:

$$
\dot{\boldsymbol{\varepsilon}}_{i j}^{\mathrm{dis}}=\dot{\boldsymbol{\varepsilon}}_{\mathrm{II}}^{\mathrm{dis}} \frac{\boldsymbol{\tau}_{i j}}{\tau_{\mathrm{II}}}=\left(2 A^{\frac{-1}{n}} f e^{\frac{Q}{n R T}}\right)^{-n} \tau_{\mathrm{II}}^{n} \frac{\boldsymbol{\tau}_{i j}}{\tau_{\mathrm{II}}}
$$

where $A$ is a pre-factor, $Q$ is the activation energy, $n$ is the stress exponent $R$ is the universal gas constant and $f$ is a correction factor (Schmalholz and Fletcher, 2011). The subscripts II stand for the square root of the second tensor invariant. The Peierls mechanism is taken into account in the mantle using the regularized formulation (Kameyama et al., 1999). The Peierls strain rate is expressed as:

$$
\dot{\boldsymbol{\varepsilon}}_{i j}^{\text {Peierls }}=\dot{\varepsilon}_{\mathrm{II}}^{\text {Peierls }} \frac{\boldsymbol{\tau}_{i j}}{\tau_{\mathrm{II}}}
$$

where the second invariant strain rate is spelled as:

$$
\left\{\begin{array}{c}
\dot{\boldsymbol{\varepsilon}}_{\mathrm{II}}^{\text {Peierls }}=\left(2 A^{\text {Peierls }}\right)^{-s} \tau_{\mathrm{II}}^{S} \frac{\boldsymbol{\tau}_{i j}}{\tau_{\mathrm{II}}} \\
A^{\text {Peierls }}=f^{\text {Peierls }} \gamma \sigma^{\text {Peierls }}\left(E^{\text {Peierls }} e^{-\frac{(1-\gamma)^{2} Q^{\text {Peierls }}}{R T}}\right)^{\frac{-1}{s}} \\
s=\frac{Q^{\text {Peierls }}}{R T}(1-\gamma)^{(q-1) q \gamma}
\end{array}\right.
$$

where $s$ is an effective temperature-dependent stress exponent, $Q^{\text {Peierls }}$ is the activation energy $(=540 \mathrm{~kJ} / \mathrm{mol}), \sigma^{\text {Peierls }}$ is the Peierls stress $\left(=8.510^{9} \mathrm{~Pa}\right), E^{\text {Peierls }}\left(=5.710^{11} \mathrm{~s}^{-1}\right)$, $q(=2.0)$, and $\gamma(=0.1)$ (Evans and Goetze, 1979).

The elastic strain rate is written as:

$$
\dot{\boldsymbol{\varepsilon}}_{i j}^{\mathrm{e}}=\frac{\breve{\tau}_{i j}}{2 G} \frac{\boldsymbol{\tau}_{i j}}{\tau_{\mathrm{II}}}
$$

where $\check{\tau}_{i j}$ is the corotational time derivative of the stress tensor (Jaumann rate) and $G$ is the shear modulus $\left(=10^{10} \mathrm{~Pa}\right)$.

The plastic strain rate takes the form of:

$$
\begin{aligned}
\dot{\boldsymbol{\varepsilon}}_{i j}^{\mathrm{p}}=\dot{\boldsymbol{\varepsilon}}_{\mathrm{II}}^{\mathrm{p}} \frac{\tau_{i j}}{\tau_{\mathrm{II}}} \text { with } \dot{\boldsymbol{\varepsilon}}_{\mathrm{II}}^{\mathrm{p}}= & \frac{F}{2 \eta^{\mathrm{ve}}} \text { and is defined only if } F=\tau_{\mathrm{II}}-C \cos \varphi- \\
& P \sin \varphi>0
\end{aligned}
$$

where $\varphi$ is the friction angle and $C$ is the cohesion (see Table 5.1 for reference model values). The coefficient $\eta^{\mathrm{ve}}$ is a visco-elastic coefficient dependent on both viscous and elastic moduli and on the time discretization (Moresi et al., 2003). No plastic strain softening was applied in the presented simulations.

The temperature is fixed at both the surface of the model $\left(0{ }^{\circ} \mathrm{C}\right)$ and the lower boundary $(1330$ ${ }^{\circ} \mathrm{C}$ ). No heat flows through the right and left boundaries. A plate convergence rate of 3 $\mathrm{cm} /$ year is achieved by prescribing constant normal inflow velocities of $\left|\mathbf{V}_{\text {in }}\right|=1.5 \mathrm{~cm} /$ year along the upper $140 \mathrm{~km}$ of the two model sides, while mass conservation is satisfied by gradually increasing outflow below $140 \mathrm{~km}$. The shear stress is set to zero along the left, right and lower boundaries. The upper boundary is a true free surface (Duretz et al., 2016b), thus its position evolves in response to tectonic loading. The initial topography is set to $0 \mathrm{~km}$. The initial temperature field is computed by solving the heat transfer equation assuming steady state and neglecting visco-plastic dissipation using the reference thermal parameters (Table 
5.1). During this initialization step, quasi-adiabatic mantle conditions are reached by assuming an artificially high conductivity within the asthenosphere.

The thermo-mechanical equations are solved using the finite difference/marker-in-cell technique (Gerya and Yuen, 2003). The global linearized system of mechanical equations is solved with a direct-iterative scheme that combines both Powell-Hestenes iterations and Cholesky factorization (Räss et al., 2017). Due to the non-linear nature of the considered rheological model, non-linear iterations are required at both local and global levels. At the local level, an exact partitioning of the strain rate tensor is obtained via successive Newton iterations(Popov and Sobolev, 2008; Schmalholz and Duretz, 2017). At the global level, Picard iterations are used to best-satisfy mechanical equilibrium equations (to an absolute tolerance of $10^{-6}$ and within a maximum of 20 iterations).

\begin{tabular}{|c|c|c|c|c|c|c|c|c|c|}
\hline & $\begin{array}{c}\rho \\
\left(\mathrm{kg} \cdot \mathrm{m}^{-3}\right)\end{array}$ & $\begin{array}{c}k \\
\left(\mathrm{~W} \cdot \mathrm{m}^{-1} \cdot \mathrm{K}^{-1}\right)\end{array}$ & $\begin{array}{c}Q_{\mathrm{r}} \\
\left(\mathrm{W} \cdot \mathrm{m}^{-3}\right)\end{array}$ & $\alpha\left(\mathrm{K}^{-1}\right)$ & $C(\mathrm{MPa})$ & $\begin{array}{c}\phi \\
\left({ }^{\circ}\right)\end{array}$ & $\begin{array}{c}A \\
\left(\mathrm{~Pa}^{-} \cdot \mathrm{s}^{-1}\right)\end{array}$ & $n$ & $\begin{array}{c}Q \\
\left(\mathrm{~J} \cdot \mathrm{mol}^{-1}\right)\end{array}$ \\
\hline $\begin{array}{c}\text { Sedimentary } \\
\text { cover (mica) }\end{array}$ & 2700 & 2.55 & $2.9 \mathrm{e}-6$ & $3.0 \mathrm{e}-5$ & 10 & 15 & $1.0 \mathrm{e}-138$ & 18 & $51.0 \mathrm{e} 3$ \\
\hline $\begin{array}{c}\text { Continental upper } \\
\text { crust (Westerly } \\
\text { granite) }\end{array}$ & 2750 & 2.8 & $1.65 \mathrm{e}-6$ & $3.0 \mathrm{e}-4$ & 10 & 30 & $\begin{array}{c}3.1623 \mathrm{e}- \\
26\end{array}$ & 3.3 & $186.5 \mathrm{e} 3$ \\
\hline $\begin{array}{c}\text { Continental lower } \\
\text { crust (mafic } \\
\text { granulite) }\end{array}$ & 2900 & 2.8 & $1.65 \mathrm{e}-6$ & $3.0 \mathrm{e}-4$ & 10 & 30 & $\begin{array}{c}8.8334 \mathrm{e}- \\
22\end{array}$ & 4.2 & $445.0 \mathrm{e} 3$ \\
\hline $\begin{array}{c}\text { Oceanic crust } \\
\text { (Maryland } \\
\text { diabase) }\end{array}$ & 2900 & 3.0 & $1.0 \mathrm{e}-10$ & $3.0 \mathrm{e}-5$ & 10 & 30 & $3.2 \mathrm{e}-20$ & 3.0 & $276.0 \mathrm{e} 3$ \\
\hline $\begin{array}{c}\text { Lithospheric } \\
\text { mantle (dry } \\
\text { olivine) }\end{array}$ & 3300 & 3.0 & $1.0 \mathrm{e}-10$ & $3.0 \mathrm{e}-5$ & 10 & 30 & $1.1 \mathrm{e}-16$ & 3.5 & $530.0 \mathrm{e} 3$ \\
\hline $\begin{array}{c}\text { Asthenosphere } \\
\text { (dry olivine) }\end{array}$ & 3300 & 3.0 & $1.0 \mathrm{e}-10$ & $3.0 \mathrm{e}-5$ & 10 & 30 & $1.1 \mathrm{e}-16$ & 3.5 & $530.0 \mathrm{e} 3$ \\
\hline $\begin{array}{c}\text { Weak zone } \\
\text { (serpentinite) }\end{array}$ & 2900 & 3.0 & $1.0 \mathrm{e}-10$ & $3.0 \mathrm{e}-5$ & 0 & 30 & $\begin{array}{c}4.4738 \mathrm{e}- \\
38\end{array}$ & 3.8 & $8.9 \mathrm{e} 3$ \\
\hline
\end{tabular}

Table 5.1. Thermal and rheological parameters used for different compositions in the reference model. The heat capacity $\left(C_{\mathrm{p}}\right)$ and the compressibility $(\beta)$, were set to $1,050 \mathrm{~J} \mathrm{~kg}^{-1}$ $\mathrm{K}^{-1}$ and $10^{-11} \mathrm{~Pa}^{-1}$ for all compositions, respectively. Rheological parameters (preexponential factor $(A)$, stress exponent $(n)$, and creep activation energy $(Q))$ are set according to flow laws of mica (Kronenberg et al., 1990), Westerly granite (Hansen and Carter, 1983), mafic granulite (Ranalli, 1995), Maryland diabase (Carter and Tsenn, 1987), dry olivine (Hirth and Kohlstedf, 2003), and serpentinite (Hilairet et al., 2007), from top to bottom in the table. Other material properties are $\rho$ : density, $k:$ thermal conductivity, $Q_{\mathrm{r}}$ : radiogenic heat production, $\alpha$ : coefficient of thermal expansion, $C$ : cohesion, $\phi$ :friction angle. 


\begin{tabular}{|c|c|c|c|c|c|c|c|c|c|}
\hline & $\begin{array}{c}\rho \\
\left(\mathrm{kg} \cdot \mathrm{m}^{-3}\right)\end{array}$ & $\begin{array}{c}k \\
\left(\mathrm{~W} . \mathrm{m}^{-1} \cdot \mathrm{K}^{-1}\right)\end{array}$ & $\begin{array}{c}Q_{\mathrm{r}} \\
\left(\mathrm{W} \cdot \mathrm{m}^{-3}\right)\end{array}$ & $\begin{array}{c}\alpha \\
\left(\mathrm{K}^{-1}\right)\end{array}$ & $\begin{array}{c}C \\
(\mathrm{MPa})\end{array}$ & $\begin{array}{c}\phi \\
\left({ }^{\circ}\right)\end{array}$ & $\begin{array}{c}A \\
\left(\mathrm{~Pa}^{-\mathrm{n}} \cdot \mathrm{s}^{-1}\right)\end{array}$ & $\begin{array}{c}Q \\
\left(\mathrm{~J} \cdot \mathrm{mol}^{-1}\right. \\
)\end{array}$ \\
\hline $\begin{array}{c}\text { Sedimentary cover } \\
\text { (mica) }\end{array}$ & 2700 & 2.55 & $2.9 \mathrm{e}-6$ & $\begin{array}{c}3.0 \mathrm{e}- \\
5\end{array}$ & 10 & 15 & $1.0 \mathrm{e}-138$ & 18 & $51.0 \mathrm{e} 3$ \\
\hline $\begin{array}{c}\text { Continental upper } \\
\text { crust (wet quartzite) }\end{array}$ & 2750 & 2.8 & $0.5 \mathrm{e}-6$ & $\begin{array}{c}3.0 \mathrm{e}- \\
4\end{array}$ & 10 & 30 & $\begin{array}{c}5.0717 \mathrm{e}- \\
18\end{array}$ & 2.3 & $154.5 \mathrm{e} 3$ \\
\hline $\begin{array}{c}\text { Continental lower } \\
\text { crust (felsic } \\
\text { granulite) }\end{array}$ & 2900 & 2.8 & $0.5 \mathrm{e}-6$ & $\begin{array}{c}3.0 \mathrm{e}- \\
4\end{array}$ & 10 & 30 & $\begin{array}{c}2.0095 \mathrm{e}- \\
21\end{array}$ & 4.2 & $243.0 \mathrm{e} 3$ \\
\hline $\begin{array}{c}\text { Oceanic crust } \\
\text { (Maryland diabase) }\end{array}$ & 2900 & 3.0 & $1.0 \mathrm{e}-10$ & $\begin{array}{c}3.0 \mathrm{e}- \\
5\end{array}$ & 10 & 30 & $3.2 \mathrm{e}-20$ & 3.0 & $276.0 \mathrm{e} 3$ \\
\hline $\begin{array}{c}\text { Lithospheric mantle } \\
\text { (dry olivine) }\end{array}$ & 3300 & 3.0 & $1.0 \mathrm{e}-10$ & $\begin{array}{c}3.0 \mathrm{e}- \\
5\end{array}$ & 10 & 30 & $1.1 \mathrm{e}-16$ & 3.5 & $530.0 \mathrm{e} 3$ \\
\hline $\begin{array}{c}\text { Asthenosphere (dry } \\
\text { olivine) }\end{array}$ & 3300 & 3.0 & $1.0 \mathrm{e}-10$ & $\begin{array}{c}3.0 \mathrm{e}- \\
5\end{array}$ & 10 & 30 & $1.1 \mathrm{e}-16$ & 3.5 & $530.0 \mathrm{e} 3$ \\
\hline $\begin{array}{c}\text { Weak zone } \\
\text { (serpentinite) }\end{array}$ & 2900 & 3.0 & $1.0 \mathrm{e}-10$ & $\begin{array}{c}3.0 \mathrm{e}- \\
5\end{array}$ & 0 & 30 & $\begin{array}{c}4.4738 \mathrm{e}- \\
38\end{array}$ & 3.8 & $8.9 \mathrm{e} 3$ \\
\hline
\end{tabular}

Table 5.2. Thermal and rheological parameters used for different compositions in the Mod 1 model variant. The heat capacity $\left(C_{\mathrm{p}}\right)$ and the compressibility $(\beta)$, were set to $1,050 \mathrm{~J} \mathrm{~kg}^{-1} \mathrm{~K}^{-1}$ and $10^{-11} \mathrm{~Pa}^{-1}$ for all compositions, respectively. Rheological parameters (pre-exponential factor $(A)$, stress exponent $(n)$, and creep activation energy $(Q))$ are set according to flow laws of mica (Kronenberg et al., 1990), wet quartzite(Ranalli, 1995), felsic granulite (Ranalli, 1995), Maryland diabase (Carter and Tsenn, 1987), dry olivine (Hirth and Kohlstedf, 2003), and serpentinite (Hilairet et al., 2007), from top to bottom in the table. Other material properties are $\rho:$ density, $k$ : thermal conductivity, $Q_{\mathrm{r}}$ : radiogenic heat production, $\alpha$ : coefficient of thermal expansion, $C$ : cohesion, $\phi$ :friction angle.

\subsubsection{Model geometry}

The computational domain is a cross section of $1330 \mathrm{x} 410 \mathrm{~km}$. The model resolution is $1 \mathrm{~km}$ in both directions. The initial compositional geometry is inspired by reconstructions of pre-obduction geodynamic settings. It contains an oceanic domain (660 km wide) with a spreading ridge and a tilted weak zone in the center that ensures left-dipping intra-oceanic subduction initiation. The thermal structure of the oceanic lithosphere is calculated by applying a half-space cooling age model from 1.5 Myr at the center to $50 \mathrm{Myr}$ at the edges of the ocean. The oceanic crust is $6 \mathrm{~km}$ thick and is overlain by a layer of uppermost sedimentary cover that linearly thickens from the ridge $(0 \mathrm{~km})$ towards the right edge of the continental domain $(3 \mathrm{~km})$. The transition from the continent to the ocean is defined by a passive margin geometry where the continental upper and lower crust linearly thin from 30 $\mathrm{km}$ to $5 \mathrm{~km}$ over the distance of $200 \mathrm{~km}$. The uppermost sedimentary cover layer has a constant $3 \mathrm{~km}$ thickness over the continental domain. 


\subsection{Supplementary Note 1: Explanation for the datasets collected from natural ophiolite belts (Figure 5.1)}

Datasets of 1) peak pressure-temperature $(P-T)$ conditions, 2) duration of continental subduction-exhumation cycle, and 3) width of ophiolite sheets were collected from ophiolite belts worldwide in order to show key characteristics and provide a robust base for comparison with our numerical simulations.

Peak $P$ - $T$ conditions of the lower plate units in obduction systems were collected from 8 ophiolite belts, from multiple structural levels, when possible (Supplementary Table 5.1). The dataset shows the dominance of $H P-L T$ metamorphism that is typical for subduction zones. Two outliers of high temperature-medium pressure $(H T-M P)$ peak conditions have been reported from Cuba (García-Casco et al., 2001) and Eastern Anatolia (Lefebvre et al., 2015). These exceptions might be explained by oblique subduction below the oceanic upper plates and/or active rifting in the upper plate still ongoing during the initial stages of continental subduction (Plunder et al., 2018; van Hinsbergen et al., 2016).

The duration of continental subduction-exhumation cycle was assessed at each natural example based on a broad literature review focusing on 1) the timing of continental subduction initiation (following the subduction of the oceanic lower plate), that is in most cases constrained by the age of the youngest passive margin sediments accreted to the front of (or overridden by) the oceanic upper plate; 2) geochronological data that constrains the timing of prograde, peak, and retrograde metamorphism and/or cooling of the continental lower plate; 3) timing indications for the surface exposure of the previously subducted continental units (timing of erosion and/or deposition of unconformably overlying sediments). Both the initiation of continental subduction and the exhumation to surface/near surface conditions are loaded with timing uncertainties. For plotting, we used the best estimation of the time that passed from the initiation of continental subduction to surface/near surface exhumation of the continental lower plate units (colored circles on Figure 5.1d). Error bars correspond to timing uncertainties that express the possible deviation from our best estimation allowed by available data. Sites where the uncertainty is well-constrained (enough data is available to bracket the uncertainty with confidence, and the interpretation of the data is not ambiguous), we used solid arrow lines for the plot (Figure 5.1d). There are sites with very limited information available regarding the timing of exhumation (e.g. Hellenides, Brooks Range), or the interpretation of geochronological data that aims to constrain exhumation (retrograde metamorphism) is debatable (e.g. Southern Ural, Cuba, Brooks Range). In these cases, we used dashed arrow lines for plotting. For the data used for plotting and main references see Supplementary Table 5.2.

We further measured the width of far-travelled ophiolite sheets that are separated from their oceanic roots (open ocean or suture zone of former ocean) by the subducted and exhumed continental units (Figure 5.1e). We measured the width in each cases along multiple sections (3-8 sections depending on the length of the ophiolite belt). The colored circle on the plot is the average of the measurements, while the error bars correspond to the maximum deviation from the average to show along-strike variation of the width. In cases where postemplacement deformation disrupted the previously coherent far-travelled sheet, we took the sum of the smaller detached sheets along the sections. A special case of far-travelled ophiolite sheets is Anatolia, where unusually large amount of ophiolite is distributed over a $400 \mathrm{~km}$ 
wide area. Reconstructions imply, that all the ophiolites currently lying on top of the continent originated from a single ocean, and were later disrupted and distributed due to postemplacement roof thrusting and extensional deformation (van Hinsbergen et al., 2016; van Hinsbergen et al., 2020). Roof-thrusting of the ophiolites occurred during the subduction and exhumation of not only one, but three major continental units below the upper plate (Kirşehir/ Tavşanl1, Afyon, and Taurides thrust sheets) that subducted one-by-one, while the previously subducted continental unit(s) was already being exhumed as part of the upper plate (van Hinsbergen et al., 2016). We therefore took the sum of the disrupted smaller ophiolite sheets along several sections as the width of the far-travelled ophiolite sheet, which can reach 150 $\mathrm{km}$, making the Anatolian sheet by far the largest (Figure 5.1e). In case of New Caledonia, our far-travelled ophiolite sheet measurements took into account the offshore extrapolation of the sheet and the exhumed HP-LT units (Patriat et al., 2018).

\subsection{Supplementary Note 2: Convergence velocity test}

Convergence velocity plays an important role in any geodynamic setting as it dictates the rate of tectonic movements and thus influences all the forces acting on the tectonic plates. Most notably, convergence velocity dictates strain rate, which has a major influence on stress distribution of the ductile lithospheric layers. Differential stress magnitudes in the ductile layers determine the degree of coupling between the brittle and ductile layers, thus strain rate (and so convergence velocity) is a key parameter in strain localization (Brun, 2002; Brun, 1999). The continental crust in our model consists of an upper and a lower crust, both constituted by brittle and ductile layers (Figure 5.2a). The coupling between these layers is substantially influenced by the strain rate (higher strain rate results in higher differential stress levels in the ductile layers, which results in higher degree of coupling). Our velocity test shows, that decreasing the convergence velocity leads to the extrusion of all the subducted continental upper crust (Supplementary Figure 5.1a), while in our reference model some of the subducted upper crust remains underplated (Figure 5.2e). This can be explained by the decreased coupling between brittle and ductile layers of the subducted crust due to the decrease in strain rate (Brun, 2002). In contrast, increasing the convergence velocity results in increased strain rates and increased coupling in the subducted crust, and hence leads to delayed extrusion (Supplementary Figure 5.1b), or no extrusion (Supplementary Figure 5.1c) of the upper crust. It has to be noted, that higher convergence velocities ( $>=5 \mathrm{~cm} / \mathrm{yr}$ ) could also produce extrusion of the upper crust similar to our reference model, if the crustal flow laws would be adjusted to the faster velocities (i.e. higher strain rates compensated by using weaker upper crustal material). 

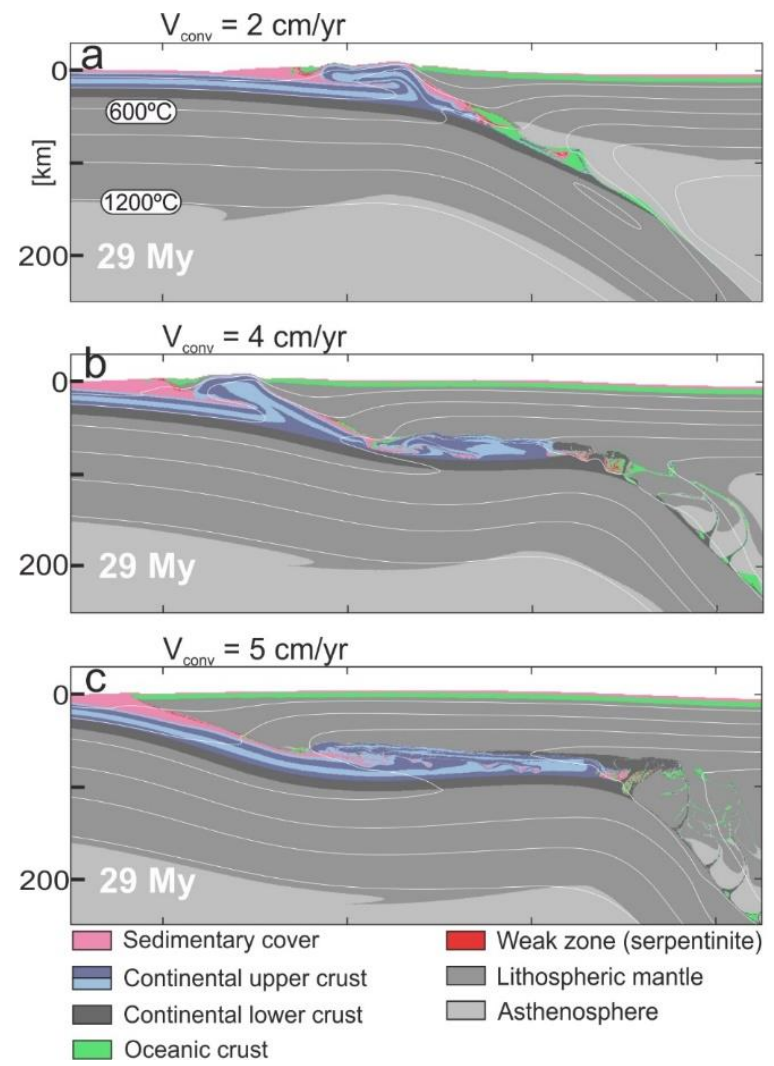

Supplementary Figure 5.1. Convergence velocity test of the reference model (Convergence velocity of the reference model is $3 \mathrm{~cm} / \mathrm{yr}$ ). (a) Model compositions at $29 \mathrm{Myr}$ for the model variant with $2 \mathrm{~cm} / \mathrm{yr}$ convergence velocity. (b) Model compositions at $29 \mathrm{Myr}$ for the model variant with $4 \mathrm{~cm} / \mathrm{yr}$ convergence velocity. (c) Model compositions at $29 \mathrm{Myr}$ for the model variant with 5 $\mathrm{cm} / \mathrm{yr}$ convergence velocity. 

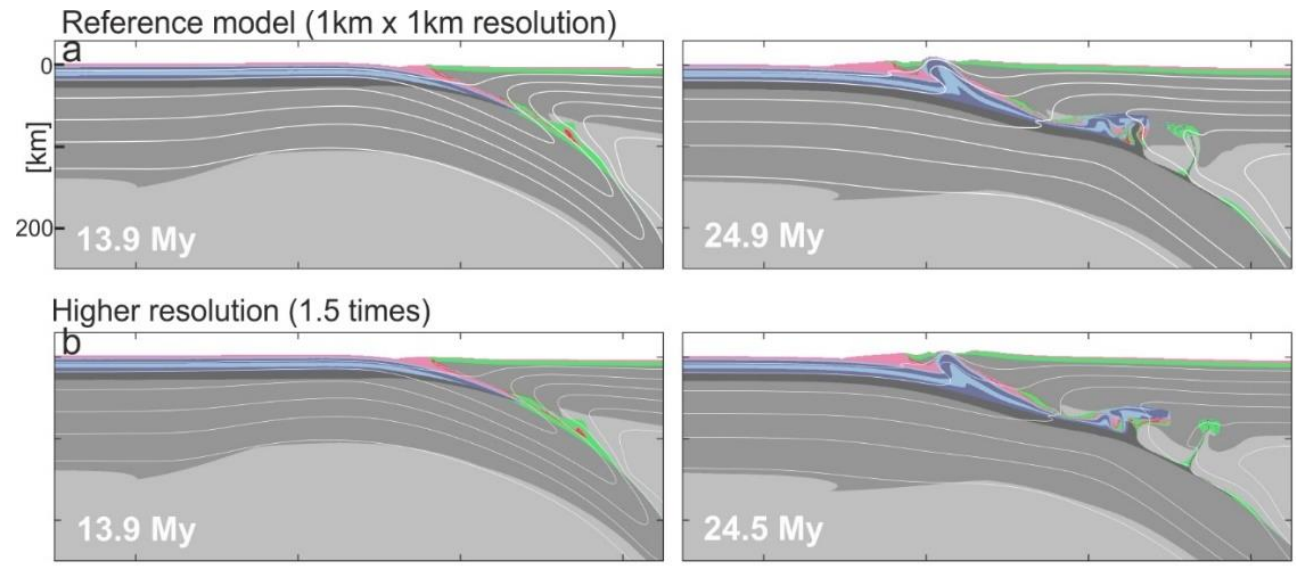

Lower resolution (1.5 times)
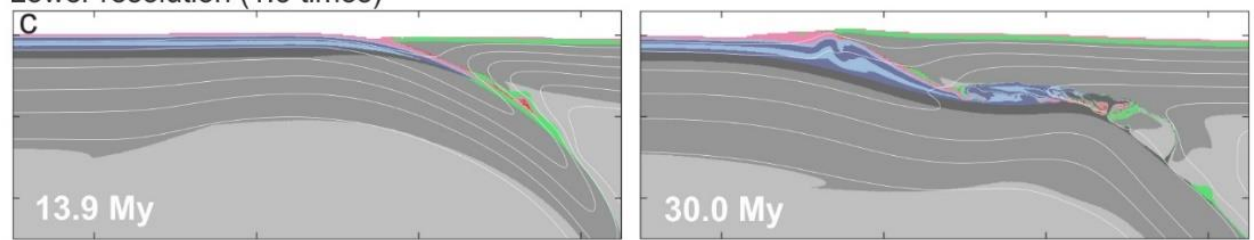

Sedimentary cover

Weak zone (serpentinite)

$\Xi$ Continental upper crust

Continental lower crust

Lithospheric mantle

Oceanic crust

Asthenosphere

Supplementary Figure 5.2. Resolution test of the reference model. (a) Reference model compositions at two snapshots. (b) Increased resolution model reproduces the reference model results with minimal differences confirming the accuracy of the results. (c) Decreased resolution model fails to reproduce reference model results as strain localization and nappe formation is prevented by the coarse resolution. 

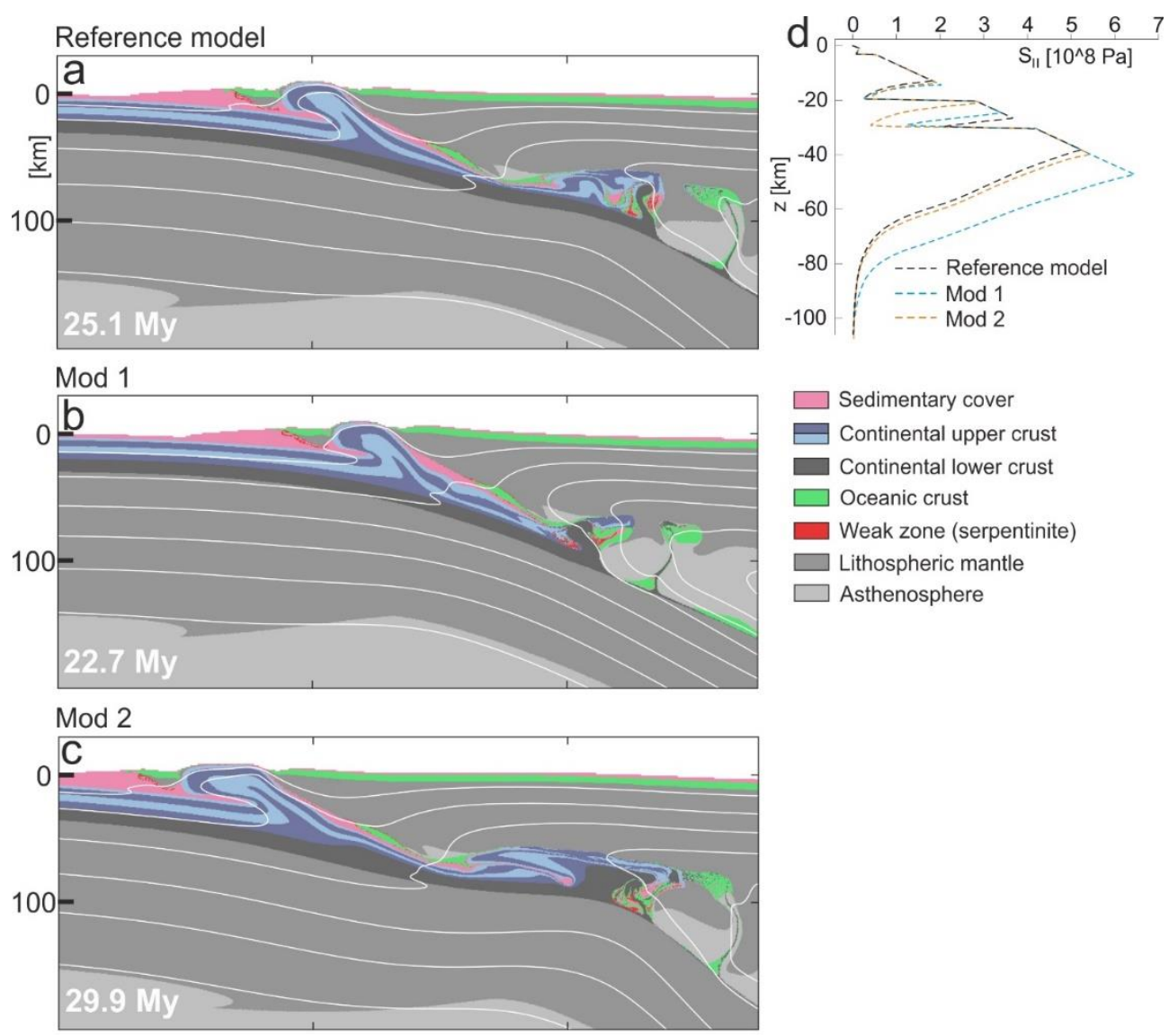

Supplementary Figure 5.3. Timing and localization of upper crustal extrusion as the function of thermal and compositional changes in a decoupled continental lithosphere. (a) Reference model compositions at 25.1 My showing moderate amount of upper crustal underplating ( 180 km long upper crust basement of the thinned passive margin), while the majority of the subducted upper crust is extruded upwards. For model parameters see Table 5.1. (b) Mod 1 variant of the reference model at 22.7 My where the heat production $(Q r)$ of the continental crust was set to $0.5 \mathrm{e}-6 \mathrm{~W} . \mathrm{m}^{-3}$, and wet quartzite/felsic granulite flow laws (Ranalli, 1995) were used for the continental upper crust/lower crust. Almost the entire subducted upper crust is being extruded with minimal underplating. (c) Mod 2 variant of the reference model at 29.9 My where the heat production $(Q r)$ of the continental crust was set to $1.5 \mathrm{e}-6 \mathrm{~W} . \mathrm{m}^{-3}$, and westerly granite/Maryland diabase flow laws (Carter and Tsenn, 1987; Hansen and Carter, 1983) were used for the continental upper crust/lower crust. A significant portion of the subducted upper crust $(\sim 300 \mathrm{~km})$ is not involved in extrusion and thus remains underplated below the oceanic upper plate. (d) Continental strength profiles (second stress invariant (Sii) vs depth (z)) of the three models (a, b, c), plotted for the initial conditions $(\mathrm{t}=0)$. 
Chapter 5: Extrusion of subducted crust explains the emplacement of far-travelled ophiolites

\begin{tabular}{|c|c|c|c|c|c|}
\hline Location & $\mathbf{T}\left[{ }^{\circ} \mathbf{C}\right]$ & P [GPa] & $\mathbf{T}_{\text {error }}\left[{ }^{\circ} \mathbf{C}\right]$ & $\mathbf{P}_{\text {error }}[\mathrm{GPa}]$ & Reference \\
\hline Oman & 525 & 2.3 & 25 & 0.1 & $\begin{array}{r}\text { (Agard et al., } \\
2010)\end{array}$ \\
\hline Oman & 300 & 1.05 & 5 & 0.05 & $\begin{array}{r}\text { (Agard et al., } \\
2010) \\
\end{array}$ \\
\hline New Caledonia & 450 & 1.625 & 20 & 0.125 & $\begin{array}{r}\text { (Brovarone and } \\
\text { Agard, 2013) }\end{array}$ \\
\hline New Caledonia & 535 & 2.4 & 15 & 0.15 & $\begin{array}{r}\text { (Brovarone and } \\
\text { Agard, 2013) } \\
\end{array}$ \\
\hline New Caledonia & 390 & 1.3 & 35 & 0.1 & $\begin{array}{r}\text { (Potel et al., } \\
2006)\end{array}$ \\
\hline Cuba (Escambray) & 570 & 2 & 40 & 0.3 & $\begin{array}{r}\text { (Stanek et al., } \\
2006)\end{array}$ \\
\hline Cuba (Pinos) & 750 & 1.15 & 25 & 0.05 & $\begin{array}{r}\text { (García-Casco et } \\
\text { al., 2001) }\end{array}$ \\
\hline Kırşehir & 700 & 0.8 & 20 & 0.05 & $\begin{array}{r}\text { (Lefebvre et al., } \\
2015)\end{array}$ \\
\hline Tavşanlı & 430 & 2.4 & 30 & 0.3 & (Okay, 2002) \\
\hline Tavşanlı & 275 & 1.2 & 25 & 0.1 & $\begin{array}{r}\text { (Plunder et al., } \\
2015)\end{array}$ \\
\hline Brooks range & 475 & 1.1 & 25 & 0.2 & $\begin{array}{r}\text { (Gottschalk and } \\
\text { Oldow, 1988) }\end{array}$ \\
\hline Brooks range & 400 & 1.05 & 30 & 0.15 & (Patrick, 1995) \\
\hline Hellenides & 500 & 2.35 & 50 & 0.15 & $\begin{array}{l}\text { (Mposkos and } \\
\text { Perraki, 2001) }\end{array}$ \\
\hline Hellenides & 460 & 1.22 & 30 & 0.1 & $\begin{array}{r}\text { (Kilias et al., } \\
2010)\end{array}$ \\
\hline Southern Ural & 575 & 2.1 & 25 & 0.4 & $\begin{array}{r}\text { (Dobretsov, } \\
1991)\end{array}$ \\
\hline
\end{tabular}

Supplementary Table 5.1. Pressure (P) and Temperature (T) data collected from the lower plate of natural ophiolite belts. 
Chapter 5: Extrusion of subducted crust explains the emplacement of far-travelled ophiolites

\begin{tabular}{|c|c|c|c|c|}
\hline Location & $\mathbf{t}[\mathbf{M y}]$ & $\mathbf{t}+[\mathbf{M y}]$ & $\mathbf{t}-[\mathbf{M y}]$ & Reference \\
\hline Brooks range & 20 & 20 & 5 & $\begin{array}{r}\text { (Harris, 1992; Hoiland } \\
\text { et al., 2018; Wirth et al., } \\
1993)\end{array}$ \\
\hline Caribbean (Pinos and Escambray) & 15 & 5 & 5 & $\begin{array}{l}\text { (García-Casco et al., } \\
\text { 2008) and references therein }\end{array}$ \\
\hline Kırşehir & 17.5 & 10 & 5 & $\begin{array}{l}\text { (van Hinsbergen et al., } \\
\text { 2016) and references therein }\end{array}$ \\
\hline Lesser Caucasus & 12.5 & 5 & 5 & $\begin{array}{r}\text { (Hässig et al., 2016; } \\
\text { Hässig et al., 2013; Rolland } \\
\text { et al., 2010) }\end{array}$ \\
\hline New Caledonia & 16 & 5 & 5 & $\begin{array}{r}\text { (Lagabrielle et al., } \\
\text { 2013; Patriat et al., 2018) } \\
\text { and references therein }\end{array}$ \\
\hline Oman & 15 & 5 & 5 & $\begin{array}{r}\text { (Agard et al., 2010; } \\
\text { Searle and Cox, 1999; } \\
\text { Searle, 2007) and references } \\
\text { therein }\end{array}$ \\
\hline Hellenides-Dinarides & 25 & 15 & 5 & $\begin{array}{r}\text { (Kilias et al., 2010; } \\
\text { Schmid et al., 2019) and } \\
\text { references therein }\end{array}$ \\
\hline Quebec & 10 & 5 & 2.5 & $\begin{array}{r}\text { (Schroetter et al., } \\
\text { 2006; Schroetter et al., 2005; } \\
\text { Whitehead et al., 1995) }\end{array}$ \\
\hline Southern Ural & 25 & 10 & 10 & $\begin{array}{r}\text { (Chemenda et al., } \\
\text { 1997; Glodny et al., 2002) } \\
\text { and references therein }\end{array}$ \\
\hline Tavşanlı & 25 & 10 & 7.5 & $\begin{array}{r}\text { (Pourteau et al., 2013; } \\
\text { van Hinsbergen et al., 2016) } \\
\text { and references therein }\end{array}$ \\
\hline
\end{tabular}

Supplementary Table 5.2. Best estimation of the continental subduction-exhumation cycle (t) based on available data, and timing uncertainties ( $t+$ and $t-)$. 


\section{Chapter 6. Synthesis}


The research objective of the presented thesis was to constrain the tectonic evolution of buried and subsequently exhumed units of continental crust and hence to improve the understanding of convergent plate boundary zones. In order to explore a wide range of processes involved, field studies were conducted in two regions of the Mediterranean orogenic system that exhibit different characteristics in terms of structure and metamorphic history: the Northern Sporades islands in Greece (Chapters 2, 3) and the Sierra de los Filábres within the Betics mountain range in SE-Spain (Chapter 4). The rocks outcropping on the Northern Sporades are characterized by low metamorphic grade (greenschist and lowtemperature blueschist facies) attesting to relatively shallow accretion of the rock units to the upper plate of the subduction system (Chapters 2, 3, Matarangas, 1992; Mposkos and Liati, 1991b). In contrast, the Sierra de los Filábres displays the high-grade metamorphic (eclogite facies) Nevado-Filábride complex attesting to the deep rock burial during subduction. The eclogite facies rocks are separated from the low-grade (low-temperature blueschist facies) Alpujárride complex by a major extensional detachment, implying significant tectonic omission along the contact (e.g. Martínez-Martínez et al., 2002; Platt et al., 1984). Therefore, these two field areas allow addressing processes associated with relatively shallow (Northern Sporades) and deep (Sierra de los Filábres) burial and subsequent exhumation of continental crust. Both areas were affected by obduction of oceanic lithosphere that were coeval with a phase of burial of continental crust. Therefore, we have supplemented our field studies by a numerical thermo-mechanical modelling study focused on understanding the process of upper crustal burial and extrusion in an obduction setting (Chapter 5). In this chapter, we compare and combine the results of the different thesis chapters in order to gain further insights regarding the evolution of continental burial-exhumation cycles.

\subsection{The tectono-metamorphic interpretation of Ar/Ar ages}

Chapters 2, 3, and 4 provide new examples that the ${ }^{40} \mathrm{Ar} /{ }^{39} \mathrm{Ar}$ dating of white micas remains a powerful tool in constraining tectonic processes, especially when combined with strategic sampling with respect to tectonic contacts and further microstructural/petrological information. The general complexity of interpreting argon data in metamorphic rocks is related to the slow and inefficient thermal diffusion under low to moderate metamorphic temperatures (< ca. $500{ }^{\circ} \mathrm{C}$, i.e. greenschist-blueschist facies conditions), which preclude the appropriate definition of 'cooling ages' related to the exhumation of the rocks (Harrison et al., 2009; Warren et al., 2012a). Hence, under metamorphic conditions that are typical for large volumes of buried and exhumed crust on Earth, the cooling age concept is not applicable. In these cases, the Ar-system is reset by deformation and/or fluid-induced crystallization processes (Villa, 1998). Consequently, the most likely events to reset the Arsystem in these rocks are fabric forming events (the formation of new tectonic foliations), which are typically related to regional deformation events during subduction and exhumation. In this sense, strategic sampling within or across shear zones (Chapters 3, 4), or the application of grain size-dependent dating corresponding to different foliations (Chapter 2) provide useful data when constraining tectonic processes. The application of multiple single grain fusion dating (Chapter 2,4) is especially advantageous as the individually calculated grain ages provide substantially more information on the overall tectonic evolution 
of the metamorphic rocks compared to conventional multi-grain methods, where the endmembers of the age mixture are unknown (e.g. Uunk et al., 2018). This thesis provides further evidence for the applicability of Ar-data in metamorphic terrains and shows that the detailed structural understanding of the dated rocks and the study area are crucial for the meaningful application of the method.

\subsection{Kinematic characteristics of continental burial-exhumation cycles}

The formations of the Northern Sporades experienced top-SW shearing during tectonic burial, and opposite-sense, top-NE shearing during exhumation (Chapters 2, 3). Top-SW shearing was related to thrusting in an accretionary wedge, while the opposite-sense, top-NE shearing during exhumation was related to the extensional reactivation of inherited thrusts and stratigraphic contacts (Chapter 3). These results fit in the regional deformation pattern of the Aegean system, as the syn-to-post-nappe stacking extensional kinematics (generally topNE, or top-SW in case of the Southern Rhodope core complex, Brun et al., 2016; Brun and Sokoutis, 2007) was (sub)parallel with the top-SW nappe stacking, and hence perpendicular to the subduction trench or the trend of the Hellenides orogen. Such a case of orogenperpendicular extension implies, that the original nappe contacts are in a favorable orientation for extensional reactivation. In the Aegean, the N-NE dipping, top-S-SW thrusts were reactivated with the opposite, top-N-NE kinematics, as observed in the area of the Northern Sporades (Chapters 2, 3), or in case of the North Cycladic extensional detachment system (Brun and Faccenna, 2008; Jolivet et al., 2010). The orogen-perpendicular direction of synto-post-orogenic extension in the Aegean region was driven by the southward direction of slab rollback (SSW in the west while SSE in the east, e.g. van Hinsbergen and Schmid, 2012), a process that created space for the extension and allowed the buried and accreted continental units to be exhumed back to the surface (Brun et al., 2016; Jolivet and Brun, 2010).

The Betics mountain range exhibit a strikingly different case regarding the relative kinematics of nappe stacking and extension. In present day orientation, the nappe contacts in the Sierra de los Filábres recorded a top-NNW sense of shear, which is at a high angle of $60^{\circ}$ to $90^{\circ}$ to the subsequent, top-W to SW displacement along the main extensional detachment system (Chapter 4, Behr and Platt, 2012). Therefore, the internal Betics document a case of orogen-parallel extension, similar to the Eastern Alps (Frisch et al., 2000), or the Southern Carpathians (Schmid et al., 1998). In such cases, contraction in one direction (ca. NW-SE in the Betics) is accommodated by perpendicular extension. In the Sierra de los Filábres, the detachment system, which accommodated the major part of syn-to-post orogenic extension, truncated the inherited, perpendicular thrusts, and localized along the brittle-ductile transition zone (Chapter 4, Martínez-Martínez and Azañón, 1997; Martínez-Martínez et al., 2002; Platt and Vissers, 1980). The opposite-sense reactivation of nappe contacts (as in case of the Aegean) was likely prohibited by the difference in the relative directions of nappe stacking and extension. The orogen-parallel extensional direction in the Betics was facilitated by the highly curved and confined slab, which retreated westward, creating space in an E-W direction (Chapter 4, e.g. van Hinsbergen et al., 2014). 


\subsection{Exhumation mechanisms of buried continental crust}

The studied field regions allowed to analyze both shallow (Northern Sporades) and deep (Sierra de los Filábres) burial and subsequent exhumation of continental crustal units. The formations of the Northern Sporades recorded ductile top-SW shearing during their latest Cretaceous-Paleogene burial, in the footwall of the Europe-derived units and the Vardar suture zone. The formations did not subduct to large depth but were accreted to the base of an accretionary wedge at low-grade (generally greenschist, locally blueschist facies) metamorphic conditions by top-S to SW thrusts. The top-SW shear fabrics are overprinted by top-NE shear fabrics, which show a gradual transition from ductile to brittle deformation mechanisms, attesting to cooling during progressive exhumation of the rocks. Top-NE shearing shows a transition to normal faulting, suggesting that the rocks were exhumed under extension (Chapters 2, 3, Figure 6.1). Prevailing extension in the accretionary wedge following the accretion of the formations suggests continuous and substantial basal accretion to the wedge, inducing uplift (Platt, 1986), and/or the retreat of subduction trench, creating space for the rocks to exhume (Brun and Faccenna, 2008).

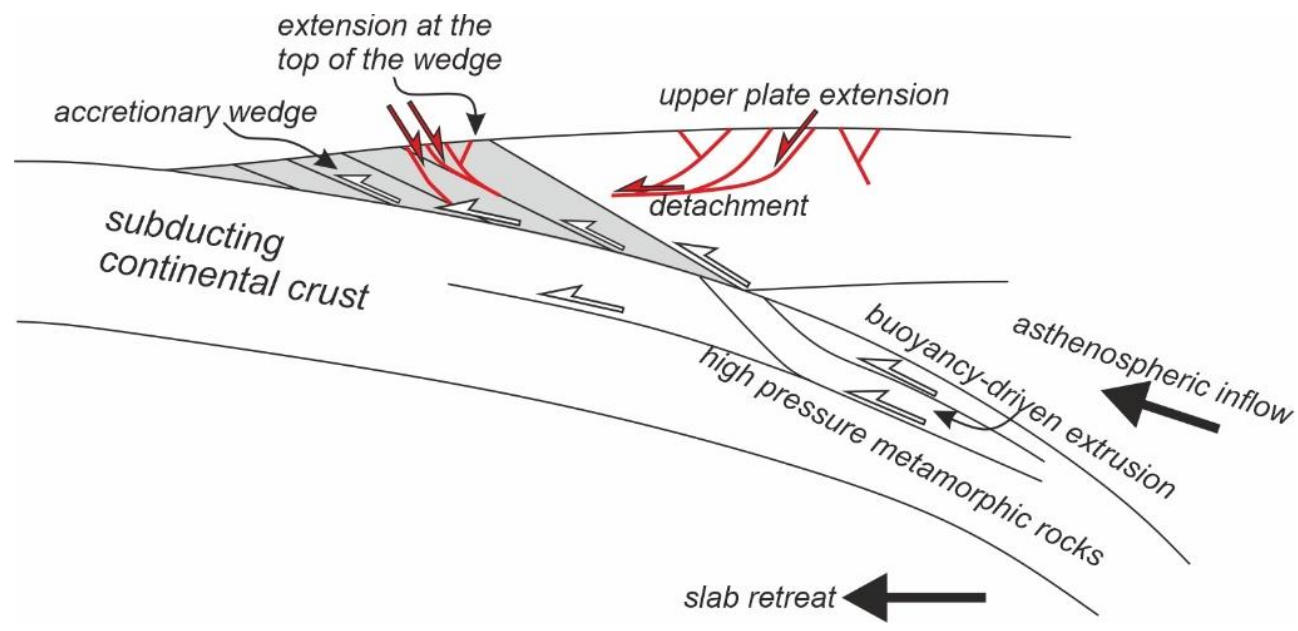

Figure 6.1. Schematic drawing of a continental subduction system highlighting the processes discussed in Chapter 6.2. Substantial crustal accretion to the accretionary wedge may result in extension at the top of the wedge, contributing to the exhumation of low-grade metamorphic rocks. The subducted part of the continental crust resists further sinking into the mantle due to its buoyancy and starts to extrude along deep thrusts. The initial extrusion of the subducted crust leads to uplift and extension in the upper plate of the subduction system and may trigger the formation of an extensional detachment along the brittle-ductile transition zone. In addition, the retreat of the subducting slab provides space for the rock exhumation.

In the Betics mountain range, the Nevado-Filábride complex experienced deep burial (subduction) below the Alboran continental domain. The main thrusts of the NevadoFilábride complex show a gradual decrease from high to low-grade metamorphic conditions during their activity, implying that nappe stacking was associated with significant exhumation. This exhumation via thrusting was coevally accommodated by the localization 
of a major extensional detachment at the brittle-ductile transition zone, above the exhuming rocks. Hence, exhumation was driven by contraction in the deeper part of the subduction zone and simultaneous extension in the upper and middle crust of the orogen (Chapter 4, Behr and Platt, 2012; Booth-Rea et al., 2015). Contractional exhumation (extrusion) of subducted continental material is typically driven by the buoyancy of the subducted continental material (Chapter 5, e.g. Chemenda et al., 1996), possibly with the additional effect of slab steepening and roll-back (Brun and Faccenna, 2008), and asthenospheric upwelling (e.g. Booth-Rea et al., 2005; Brun and Faccenna, 2008). The thermo-mechanical models in Chapter 5 show that nappe formation in the subducted upper crust also triggers uplift and local extension of the upper plate in an obduction setting. There, the extensional shear zones accommodate the extrusion of the upper crust and break the oceanic upper plate, eventually leading to fartravelled ophiolite emplacement. A similar causal relationship between crustal extrusion and detachment formation could be envisaged for the exhumation of the Nevado-Filábride complex in the Betics orogen (Figure 6.1). In the Betics, the main extensional detachment that cut through the former nappe contacts might have formed as a response to the uplift induced by the initial extrusion of the subducted Nevado-Filábride complex, as supported by timing, petrological, and structural data (Chapter 4, Behr and Platt, 2012; Booth-Rea et al., 2015). While acknowledging the importance of buoyancy forces, the generic model of Brun and Faccenna (2008) invokes slab steepening and retreat as the main drivers for the exhumation of subducted rocks. This model includes asthenospheric inflow during the exhumation of high-pressure rocks, allowed by the delamination of the lithospheric mantle. This and similar interpretations invoking asthenospheric upwelling have been widely considered to explain the re-heating of the high pressure-low temperature rocks during their exhumation, including the Nevado-Filábride complex (Behr and Platt, 2012; Booth-Rea et al., 2005) and the Cycladic high pressure-low temperature rocks in the Aegean region (Brun et al., 2016; Jolivet and Brun, 2010), suggesting that besides crustal buoyancy, the interplay between slab rollback, lithospheric mantle delamination, and asthenospheric upwelling is key in the exhumation of subducted continental crust and the formation of extensional orogenic domes. 


\section{Summary}

Continental burial-exhumation cycles play a major role in the evolution of subduction zones, one of the main drivers behind our dynamic planet. Constraining the structural and temporal evolution of continental subduction systems is hence crucial for understanding the geodynamic evolution of Earth and the architecture of mountain belts. The investigation of continental burial-exhumation processes requires the application of multiple research methods, to constrain the structure (structural geology), timing (geochronology), pressuretemperature conditions (metamorphic petrology), and the overall physical evolution (geodynamic modelling).

The thesis aims to improve the understanding of continental burial-exhumation cycles by using structural analysis, ${ }^{40} \mathrm{Ar} /{ }^{39} \mathrm{Ar}$ dating of white micas, petrological observations, and numerical thermo-mechanical modelling. The studies furthermore build on the large amount of previously published data - mostly in the Mediterranean region but also elsewhere - that serve as a basis for comparison and combination with the presented new data. The thesis contains field studies of continental burial-exhumation cycles from the Eastern Mediterranean (Hellenides, Chapters 2 and 3) and the Western Mediterranean (Betics, Chapter 4), and a numerical modelling study validated against a global geological dataset, investigating the dynamics of obduction systems (Chapter 5).

Chapter 2 presents a field study from the island of Skopelos (Northern Sporades, Greece) that integrates structural and petrological analyses with white mica ${ }^{40} \mathrm{Ar} /{ }^{39} \mathrm{Ar}$ dating in order to delineate phases of tectonic burial and exhumation and to determine their timing, kinematics, and metamorphic conditions. Two major progressive phases of ductile deformation are documented, which are related to distinct episodes of tectonic burial and exhumation of the Pelagonian continental margin. The first phase of tectonic burial and exhumation is defined by Early Cretaceous $(\sim 105-135 \mathrm{Ma}){ }^{40} \mathrm{Ar} /{ }^{39} \mathrm{Ar}$ white mica single grain fusion ages, correlated with the initial closure of the Neotethys/Vardar ocean by ophiolite obduction and the underthrusting of the Pelagonian margin below the oceanic upper plate. Underthrusting was followed by exhumation and the deposition of Late CretaceousPaleogene sediments. The second phase of burial and exhumation is characterized by NESW tectonic transport, greenschist to blueschist facies metamorphism, and latest CretaceousEarly Eocene ${ }^{40} \mathrm{Ar} /{ }^{39} \mathrm{Ar}$ white mica fabric ages. Burial of the Pelagonian crust below the Eurasian continent (Rhodopia) resulted in top-SW shearing, followed by opposite-sense topNE shearing during extensional exhumation. The defined tectono-metamorphic events are further correlated within the broad Dinarides-Hellenides orogenic system based on literature data.

The geological record of the second, latest Cretaceous-Paleogene burial-exhumation cycle is well-preserved in the upper crustal metasedimentary rocks that constitute the Northern Sporades islands. Hence, the islands provide an excellent opportunity to study strain localization processes during the burial and exhumation of the continental upper crust, which is the focus of Chapter 3. In particular, we studied the role of structural inheritance in the evolution of extensional shear zones as well as the role of mechanical stratigraphy in strain localization during burial and exhumation. We applied detailed structural analysis 
supplemented by the ${ }^{40} \mathrm{Ar} /{ }^{39} \mathrm{Ar}$ dating of key shear zones on the islands of Skiathos and Skopelos. The results show that the presence of shallow decoupling levels in the upper crust due to mechanical stratigraphy resulted in the formation of thin (several $100 \mathrm{~m}$ thick) thrust sheets that are defined for the first time on Skiathos. Subsequently, extension was accommodated by opposite-sense, generally top-NE, ductile to brittle shearing, which localized at inherited heterogeneities such as reverse-sense shear zones and stratigraphic contacts. The dense network of northerly-dipping, inherited weakness zones resulted in a highly distributed pattern of extensional deformation dominated by layer-parallel shearing.

The mechanics of superposed nappe-stacking and extensional exhumation, and their implications for the geodynamics of mountain belts and paleo-geographic reconstructions, also remain key problems in the Western Mediterranean region. Chapter 4 presents a field study applying structural analysis and ${ }^{40} \mathrm{Ar} /{ }^{39} \mathrm{Ar}$ dating in the Sierra de los Filábres (Betics mountain range, SE-Spain) in order to constrain the timing of subduction, the definition of tectonic units including the significance of ocean-derived rocks, and the kinematic evolution of main shear zones in the core of the orogen (Nevado-Filábride Complex). Benefiting from the large available dataset of previous studies, the new results demonstrate a novel separation of continental- and oceanic- derived tectonic units that were stacked during a two-stage tectonic evolution. Our ${ }^{40} \mathrm{Ar} /{ }^{39} \mathrm{Ar}$ ages display two age populations (38-27 Ma and 22-12 Ma), interpreted as the record of Ar-loss due to deformation-or fluid-induced recrystallization during two distinct fabric-forming periods, related to successive burial-exhumation cycles. We interpret the Paleogene burial of the NFC to be the result of the obduction of an oceanic lithosphere, formed in the Alpine Tethys adjacent to the Iberian margin. Obduction was followed by the Miocene subduction of the Nevado-Filábride Complex together with the obducted ophiolites, below the Alboran continental crust. Subsequent exhumation of the rocks was controlled by a major extensional detachment, which obliquely cut through the inherited nappe stack, possibly resulting in the juxtaposition of the same original lithologies metamorphosed in contrasting grades.

The interplay between continental subduction-exhumation dynamics and the obduction of ophiolite sheets remains an enigmatic chapter in plate tectonics. Here we combine data collected from ophiolite belts worldwide with thermo-mechanical simulations of continental subduction dynamics to show the causal link between the extrusion of subducted continental crust and the emplacement of far-travelled ophiolite sheets. Our results reveal that buoyancydriven extrusion of subducted crust triggers necking and breaking of the overriding oceanic upper plate. The broken-off piece of oceanic lithosphere is then transported on top of the continent along a flat thrust segment and becomes a far-travelled ophiolite sheet separated from its root by the extruded continental crust. Our model carries implications for the tectonic evolution of ophiolite belts worldwide as well as for continental subduction-exhumation processes in general. 


\section{Samenvatting}

Cycli van continentale begraving-en-exhumatie spelen een grote rol in de ontwikkeling van subductiezones, die een van de belangrijkste geodynamische processen zijn van onze planeet. Het onderzoeken en karakteriseren van de ontwikkeling van subductiezones is dan ook van cruciaal belang om de geodynamische evolutie van de aarde te begrijpen, en daarmee ook de opbouw van gebergteketens. Een combinatie van onderzoeksmethodieken is nodig om de structuur (structurele geologie), duur (geochronologie), druk- en temperatuurcondities (metamorfe petrologie) en de grootschalige fysieke evolutie (geodynamisch modelleren) van continentale begravings-en-exhumatieprocessen te kunnen bestuderen.

Dit promotieonderzoek richtte zich op een beter begrip van continentale begravings- en exhumatiecycli door een gecombineerde studie van structurele analyse, ${ }^{40} \mathrm{Ar} /{ }^{39} \mathrm{Ar}$ datering van witte mica's, petrologische gegevens en numeriek thermo-mechanisch modelleren. Deze onderzoeken zijn mede gebaseerd op een groot aantal eerder gepubliceerde gegevens (meest afkomstig uit het Mediterrane gebied, maar ook van elders), die gebruikt worden als vergelijkingsmateriaal en gecombineerd met nieuwe gegevens. De dissertatie beschrijft de resultaten van veldstudies van continentale begravings- en exhumatiecycli in de oostelijke Mediterranee (de Helliniden, hoofdstukken 2 en 3) en de westelijke Mediterranee (Betics, hoofdstuk 4), en van een numerieke modelleerstudie van de dynamica van obductiesystemen, gevalideerd met wereldwijde geologische gegevens (hoofdstuk 5).

In Hoofdstuk 2 worden de resultaten gepresenteerd van een veldstudie van het Griekse eiland Skopelos (noordelijke Sporaden). Hierin worden structureel geologische en petrologische analyses gecombineerd met ${ }^{40} \mathrm{Ar} /{ }^{39} \mathrm{Ar}$ ouderdomsdatering van witte mica's voor het identificeren van fases, timing, en kinematische en metamorfe condities van tektonische begraving en opheffing. Er blijken twee grote, progressieve fasen van ductiele deformatie te zijn, beide gerelateerd aan concrete perioden van tektonische begraving en exhumatie van de Pelagonische continentale marge. De eerste fase wordt gekarakteriseerd door Vroeg Krijt ( $105-135 \mathrm{Ma}){ }^{40} \mathrm{Ar} /{ }^{39} \mathrm{Ar}$ ouderdommen van witte mica korrelversmelting, die gecorreleerd kan worden met initiële sluiting van de Neotethys/Vardar oceaan door ofioliet-obductie en met het onderschuiven van de Pelagonische marge onder de oceanische plaat. Dit onderschuiven werd gevolgd door exhumatie en depositie van Laat Krijt-Paleogene sedimenten. De tweede fase wordt gekarakteriseerd door NE-SW tektonisch transport, groenschist tot blauwschist metamorfisme, en Laat Krijt/Vroeg Eocene ${ }^{40} \mathrm{Ar} /{ }^{39} \mathrm{Ar}$ ouderdommen van witte mica's. De begraving van de Pelagonische korst onder het Euraziatische continent (Rhodopia) leidde eerst tot top-SW verschuiving, daarna gevolgd door tegengesteld gerichte top-NE verschuiving tijdens rek-gerelateerde exhumatie.

De geologische geschiedenis van de tweede, Laat Krijt-Paleogene begraving-exhumatie cyclus is goed bewaard gebleven in de meta-sedimentaire bovenkorstgesteenten waaruit de noordelijke Sporaden bestaan. Deze eilanden bieden dan ook een ideale gelegenheid voor het bestuderen van lokalisatie van deformatie tijdens het begraven en exhumeren van continentale bovenkorst, wat het onderwerp is van Hoofdstuk 3. Daarbij is met name gekeken naar de invloed van al bestaande structuren op de ontwikkeling van extensie gerelateerde verschuivingszones, en naar de rol van mechanische stratificatie op lokalisatie van deformatie tijdens begraving en exhumatie. Er is, in combinatie met ${ }^{40} \mathrm{Ar} /{ }^{39} \mathrm{Ar}$ ouderdomsdatering, een gedetailleerde structureel geologische analyse uitgevoerd van de belangrijkste 
verschuivingszones op de eilanden Skiathos en Skopelos. In dit onderzoek wordt voor het eerst aangetoond dat er op Skiathos door mechanische stratificatie in de bovenkorst, ondiepe ontkoppelingsniveaus aanwezig zijn die verantwoordelijk zijn voor de vorming van dunne (enkele $100 \mathrm{~m}$ dikke) overschuivingslagen. Daaropvolgende rek werd geaccommodeerd door ductiel-brosse verschuiving in tegengestelde, meest NE richting, die zich lokaliseerde op al bestaande heterogeniteiten, zoals tegengesteld-gerichte verschuivingszones en stratigrafische contacten. Het dichte netwerk van de al bestaande noord-hellende zwaktezones resulteerde in een wijdverbreid patroon van extensiedeformatie, gedomineerd door laag-parallelle verschuiving.

De mechanica van de opeenvolging van nappe-stapeling en extensie-exhumatie, en de implicaties daarvan voor de geodynamica van gebergteketens en paleo-geografische reconstructies, blijven een belangrijk probleem in de westelijke Mediterranee. Hoofdstuk 4 presenteert de resultaten van een veldstudie in de Sierra de los Filábres (Betics gebergte, ZOSpanje), waar een structureel geologische analyse en ${ }^{40} \mathrm{Ar} /{ }^{39} \mathrm{Ar}$ ouderdomsdatering zijn uitgevoerd voor het bepalen van de timing van subductie, het definiëren van tektonische eenheden inclusief het belang van oceanische gesteenten, en de kinematische ontwikkeling van grote verschuivingszones in de kern van het orogeen (Nevado-Filábride Complex, NFC). De nieuwe resultaten demonstreren, mede dankzij de grote hoeveelheid beschikbare gegevens afkomstig van eerdere studies, een nieuw mechanisme van scheiding van continentale en oceanische tektonische eenheden, die gestapeld worden in een tweetraps tektonische evolutie. De bepaalde ${ }^{40} \mathrm{Ar} /{ }^{39} \mathrm{Ar}$ ouderdommen zijn verdeeld in twee groepen (38$27 \mathrm{Ma}$ en 22-12 Ma). Dit is het gevolg van Ar-verlies veroorzaakt door deformatie- of vloeistof-geïnduceerde rekristallisatie tijdens twee discrete perioden van (her)vorming van gesteentestructuur, gerelateerd aan opeenvolgende begravings- en-exhumatie cycli. De Paleogene begraving van het NFC wordt geïnterpreteerd als zijnde het resultaat van obductie van oceanische lithosfeer, gevormd in de Alpiene Tethys naast de Iberische marge. De obductie werd in het Mioceen gevolgd door subductie van het NFC en de geöbduceerde ofiolieten onder de Alboran continentale korst. Daaropvolgende exhumatie was het gevolg van een grote extensie ontkoppeling die schuin door de geërfde nappe-stapeling sneed, en die mogelijk resulteerde in een juxtapositie van eenheden van dezelfde lithologie, maar met verschillende gradaties van metamorfose.

De wisselwerking tussen het dynamisch continentale subductie-exhumatie proces en de obductie van ofiolietbladen blijft een raadsel in plaattektoniek. In dit onderzoek zijn wereldwijde gegevens van ofiolietgordels gecombineerd met thermo-mechanische computersimulaties van dynamische continentale subductieprocessen om het causale verband aan te tonen tussen extrusie van gesubduceerde continentale korst en de plaatsing van over grote afstand verschoven ofiolietbladen. De resultaten van het onderzoek laten zien dat de, door het drijfvermogen geinduceerde, extrusie van gesubduceerde korst leidt tot het plaatselijk verdunnen en uiteindelijk opbreken van de bovenliggende oceanische plaat. Het afgebroken stuk oceanische plaat schuift daarbij op het continent langs een platte overschuivingsbreuk, en wordt op die manier een ofioliet die door de geëxtrudeerde continentale korst ver verwijderd is van zijn oorsprong. Het gepresenteerde nieuwe model heeft implicaties voor zowel de tektonische ontwikkeling van ofiolietgordels overal op de aarde, alsmede meer in het algemeen voor continentale subductie-exhumatie processen. 


\section{Acknowledgements}

This thesis is a summit that follows some very exciting and eventful years in my life, which materialized with the help and support of many people around me.

Firstly, I thank my promoters, Dimitrios and Liviu, and my co-promoters, Ernst and Fred for giving me the opportunity to carry out a $\mathrm{PhD}$ project in the excellent research environment of the Tectonics group.

Ernst, your enthusiastic and constructive supervision was very much appreciated all the way through. Thank you for always being there and ready when I had anything to discuss, for supporting the research directions I initiated, for always providing constructive feedback, and for the great times in the field.

Dimitrios, your stylish guidance was much appreciated in the first half of my project. Special thanks is due for properly introducing me to Greece and to the loukoumades. The field work on the Sporades was sublime fun that I will never forget.

Liviu, I am really grateful that you brought me to the Betics, for your enthusiastic supervision in that chapter, and for the plenty of helpful advises throughout my whole project. I will keep on trying to see through the metamorphism.

Jan, your expert guidance on Ar/Ar dating and constructive feedback on the manuscripts were greatly appreciated.

Thibault and Philippe, thank you for welcoming me in Rennes and for your quick and constructive help throughout our very exciting project, it has all been a great pleasure.

I would like to express my gratitude to the members of the reading committee: Prof. Carmen Gaina, Prof. Franz Neubauer, Prof. Frédèric Gueydan, Prof. Martyn Drury, and Dr. Evangelos Moulas.

I am really grateful for the research funding, excellent field trips, short courses, project meetings, and alternative forms of entertainment during the three years of the SUBITOP project. I learned a lot, and had the chance to be part of a really inspiring and fun group of researchers. Big thank you for the whole SUBITOP team!

Many thanks to the colleagues in the Tectonics group who provided me with a great working atmosphere and plenty of splendid discussions: Sierd, Ylona, Jan-Diederik, Jeroen, Damien, Nevena, Inge, Alessio, Magdala, Lukman, Fauzi, Job, Manfred, István, and all other Tectos I had the pleasure to meet. It was great to have Dani and Attila around for a while and enjoy some Hungarian-style quality time. I have very nice memories of pre-covid activities in and around Utrecht, which would not have been the same without the excellent company of Antoine, Tracy, Nemanja, Jon, Marije, and Simon. Here I also thank Antoine and Eszti for being my paranymphs, your company and support of many kinds were invaluable during my $\mathrm{PhD}$. 
I always enjoyed and learned a lot from co-supervising my BSc or MSc students in the field or back in the office. Special thanks goes to Iverna and Jasper, who accompanied me for multiple research projects.

I really appreciated the teaching experience in the Betics, many thanks to Hans, Frits, Douwe, and Liviu for the excellent company and guidance.

A year before I started my $\mathrm{PhD}$, I had a fantastic sailing holiday with the négyes around the Northern Sporades islands. Those islands ended up being the main field area for my $\mathrm{PhD}$ work, hence my appreciation goes to haversrácok for laying such a solid emotional foundation for the project.

Last but not least, I would like to say köszönöm to my family and all of my friends for the support and good times. I specially thank my daughter, Anna, for being a very good sleeper as well as a fun company; her contribution to the thesis in these manners must be immense. I finally thank my wonderful wife, Eszti, for being constantly by my side. This thesis and everything else in our lives is achieved and enjoyed in great togetherness. 
Agard, P., Jolivet, L., and Goffe, B., 2001, Tectonometamorphic evolution of the Schistes Lustres Complex; implications for the exhumation of HP and UHP rocks in the Western Alps: Bulletin de la Société géologique de France, v. 172, no. 5, p. 617 636.

Agard, P., Jolivet, L., Vrielynck, B., Burov, E., and Monie, P., 2007, Plate acceleration: the obduction trigger?: Earth and Planetary Science Letters, v. 258, no. 3-4, p. 428-441.

Agard, P., Searle, M. P., Alsop, G. I., and Dubacq, B., 2010, Crustal stacking and expulsion tectonics during continental subduction: P-T deformation constraints from Oman: Tectonics, v. 29, no. 5.

Agard, P., and Vitale-Brovarone, A., 2013, Thermal regime of continental subduction: the record from exhumed HP-LT terranes (New Caledonia, Oman, Corsica): Tectonophysics, v. 601, p. 206-215.

Agard, P., Yamato, P., Soret, M., Prigent, C., Guillot, S., Plunder, A., Dubacq, B., Chauvet, A., and Monié, P., 2016, Plate interface rheological switches during subduction infancy: Control on slab penetration and metamorphic sole formation: Earth and Planetary Science Letters, v. 451, p. 208-220.

Agard, P., Zuo, X., Funiciello, F., Bellahsen, N., Faccenna, C., and Savva, D., 2014, Obduction: Why, how and where. Clues from analog models: Earth and Planetary Science Letters, v. 393, p. 132-145.

Altherr, R., Schliestedt, M., Okrusch, M., Seidel, E., Kreuzer, H., Harre, W., Lenz, H., Wendt, I., and Wagner, G. A., 1979, Geochronology of high-pressure rocks on Sifnos (Cyclades, Greece): Contributions to Mineralogy and Petrology, v. 70, no. 3, p. 245-255.

Andersen, T., Skjerlie, K., and Furnes, H., 1990, The Sunnfjord Melange, evidence of Silurian ophiolite accretion in the west Norwegian Caledonides: Journal of the Geological Society, v. 147, no. 1, p. 59-68.

Arca, M. S., Kapp, P., and Johnson, R. A., 2010, Cenozoic crustal extension in southeastern Arizona and implications for models of core-complex development: Tectonophysics, v. 488, no. 1-4, p. 174-190.

Aubouin, J., Bonneau, M., Davidson, J., Leboulenger, P., Matesco, S., and Zambetakis, A., 1976, Esquisse structurale de 19Arc egeen externe; des Dinarides aux Taurides: Bulletin de la Societé géologique de France, v. 7, no. 2, p. 327-336.

Augier, R., Agard, P., Monié, P., Jolivet, L., Robin, C., and Booth-Rea, G., 2005a, Exhumation, doming and slab retreat in the Betic Cordillera (SE Spain): in situ40Ar/39Ar ages and P-T-d-t paths for the Nevado-Filabride complex: Journal of Metamorphic Geology, v. 23, no. 5, p. 357-381.

Augier, R., Booth-Rea, G., Agard, P., Martínez-Martínez, J. M., Jolivet, L., and Azañón, J. M., 2005b, Exhumation constraints for the lower Nevado-Filabride Complex (Betic Cordillera, SE Spain): a Raman thermometry and Tweequ multiequilibrium thermobarometry approach: Bulletin de la société géologique de france, v. 176, no. 5, p. 403-416.

Augier, R., Jolivet, L., and Robin, C., 2005c, Late Orogenic doming in the eastern Betic Cordilleras: Final exhumation of the Nevado-Filabride complex and its relation to basin genesis: Tectonics, v. 24, no. 4.

Axen, G. J., 2019, How a strong low-angle normal fault formed: The Whipple detachment, southeastern California: Geological Society of America Bulletin. 
Axen, G. J., Bartley, J. M., and Selverstone, J., 1995, Structural expression of a rolling hinge in the footwall of the Brenner Line normal fault, eastern Alps: Tectonics, v. 14, no. 6, p. 1380-1392.

Axen, G. J., and Selverstone, J., 1994, Stress state and fluid-pressure level along the Whipple detachment fault, California: Geology, v. 22, no. 9, p. 835-838.

Azañón, J., García-Dueñas, V., and Goffé, B., 1998, Exhumation of high-pressure metapelites and coeval crustal extension in the Alpujarride complex (Betic Cordillera): Tectonophysics, v. 285, no. 3-4, p. 231-252.

Azañón, J. M., Crespo-blanc, Ana, García-Dueñas, V, 1997, Continental collision, crustal thinning and nappe forming during the pre-Miocene evolution of the Alpujarride Complex (Alboran Domain, Betics): Journal of Structural Geology, v. 19, no. 8, p. 1055-1071.

Balanyá, J., and García-Dueñas, V., 1987, Les directions structurales dans le Domaine d'Alborán de part et d'autre du Détroit de Gibraltar: Comptes rendus de l'Académie des sciences. Série 2, Mécanique, Physique, Chimie, Sciences de l'univers, Sciences de la Terre, v. 304 , no. 15 , p. 929-932.

Balázs, A., Burov, E., Matenco, L., Vogt, K., Francois, T., and Cloetingh, S., 2017, Symmetry during the syn-and post-rift evolution of extensional back-arc basins: The role of inherited orogenic structures: Earth and Planetary Science Letters, v. 462, p. 86-98.

Barth, M. G., Mason, P. R., Davies, G. R., and Drury, M. R., 2008, The Othris Ophiolite, Greece: a snapshot of subduction initiation at a mid-ocean ridge: Lithos, v. 100, no. 1, p. 234-254.

Behr, W., and Platt, J., 2012, Kinematic and thermal evolution during two-stage exhumation of a Mediterranean subduction complex: Tectonics, v. 31, no. 4.

Beltrando, M., Lister, G. S., Forster, M., Dunlap, W. J., Fraser, G., and Hermann, J., 2009, Dating microstructures by the 40Ar/39Ar step-heating technique: deformationpressure-temperature-time history of the Penninic Units of the Western Alps: Lithos, v. 113, no. 3-4, p. 801-819.

Beniest, A., Brun, J.-P., Gorini, C., Crombez, V., Deschamps, R., Hamon, Y., and Smit, J., 2016, Interaction between trench retreat and Anatolian escape as recorded by Neogene basins in the northern Aegean Sea: Marine and Petroleum Geology, v. 77, p. 30-42.

Bessière, E., 2019, Évolution géodynamique des Zones Internes des Cordillères Bétiques (Andalousie, Espagne): Apports d'une étude pluridisciplinaire du Complexe Alpujárride: Université d'Orléans.

Blake, M., Bonneau, M., Geyssant, J., Kienast, J., Lepvrier, C., Maluski, H., and Papanikolaou, D., 1981, A geologic reconnaissance of the Cycladic blueschist belt, Greece: Geological Society of America Bulletin, v. 92, no. 5, p. 247-254.

Bonev, N., Spikings, R., Moritz, R., Marchev, P., and Collings, D., 2013, 40Ar/39Ar age constraints on the timing of Tertiary crustal extension and its temporal relation to ore-forming and magmatic processes in the Eastern Rhodope Massif, Bulgaria: Lithos, v. 180, p. 264-278.

Bonev, N. G., and Stampfli, G. M., 2003, New structural and petrologic data on Mesozoic schists in the Rhodope (Bulgaria): geodynamic implications: Comptes Rendus Geoscience, v. 335, no. 8, p. 691-699.

Booth-Rea, G., Azañón, J. M., and García-Dueñas, V. c., 2004, Extensional tectonics in the northeastern Betics (SE Spain): case study of extension in a multilayered upper crust with contrasting rheologies: Journal of Structural Geology, v. 26, no. 11, p. 20392058 . 
Booth-Rea, G., Azañón, J. M., Goffé, B., Vidal, O., and Martínez-Martínez, J. M., 2002, High-pressure, low-temperature metamorphism in Alpujarride units of southeastern Betics (Spain): Comptes Rendus Geoscience, v. 334, no. 11, p. 857-865.

Booth-Rea, G., Bardají Azcárate, T., and Santos-García, J. A., 2009a, Mapa Geologico MAGNA de Águilas (997), MAGNA de Murcia.

Booth-Rea, G., Bardají Azcárate, T., and Santos-García, J. A., 2009b, Mapa Geologico MAGNA de Puerto Lumbreras (975), MAGNA de Murcia.

Booth-Rea, G., Martínez-Martínez, J., and Giaconia, F., 2015, Continental subduction, intracrustal shortening, and coeval upper-crustal extension: PT evolution of subducted south Iberian paleomargin metapelites (Betics, SE Spain): Tectonophysics, v. 663, p. 122-139.

Booth-Rea, G., Azañón, J. M., Martínez-Martínez, J. M., Vidal, O., and García-Dueñas, V., 2005, Contrasting structural and P-T evolution of tectonic units in the southeastern Betics: Key for understanding the exhumation of the Alboran Domain HP/LT crustal rocks (western Mediterranean): Tectonics, v. 24, no. 2.

Booth-Rea, G., Ranero, C. R., Martínez-Martínez, J. M., and Grevemeyer, I., 2007, Crustal types and Tertiary tectonic evolution of the Alborán sea, western Mediterranean: Geochemistry, Geophysics, Geosystems, v. 8, no. 10.

Bortolotti, V., Chiari, M., Marroni, M., Pandolfi, L., Principi, G., and Saccani, E., 2013, Geodynamic evolution of ophiolites from Albania and Greece (Dinaric-Hellenic belt): one, two, or more oceanic basins?: International Journal of Earth Sciences, v. 102, no. 3, p. 783-811.

Bortolotti, V., Marroni, M., Pandolfi, L., and Principi, G., 2005, Mesozoic to Tertiary tectonic history of the Mirdita ophiolites, northern Albania: Island Arc, v. 14, no. 4, p. 471 493.

Bortolotti, V., and Principi, G., 2005, Tethyan ophiolites and Pangea break-up: Island Arc, v. 14 , no. 4 , p. $442-470$.

Boudier, F., Ceuleneer, G., and Nicolas, A., 1988, Shear zones, thrusts and related magmatism in the Oman ophiolite: initiation of thrusting on an oceanic ridge: Tectonophysics, v. 151, no. 1-4, p. 275-296.

Bouillin, J.-P., Durand-Delga, M., and Olivier, P., 1986, Betic-Rifian and Tyrrhenian arcs: distinctive features, genesis and development stages, Developments in Geotectonics, Volume 21, Elsevier, p. 281-304.

Bröcker, M., Baldwin, S., and Arkudas, R., 2013, The geological significance of 40Ar/39Ar and $\mathrm{Rb}-\mathrm{Sr}$ white mica ages from Syros and Sifnos, Greece: a record of continuous (re) crystallization during exhumation?: Journal of Metamorphic Geology, v. 31, no. 6, p. 629-646.

Bröcker, M., Kreuzer, H., Matthews, A., and Okrusch, M., 1993, 40Ar/39Ar and oxygen isotope studies of polymetamorphism from Tinos Island, Cycladic blueschist belt, Greece: Journal of metamorphic Geology, v. 11, no. 2, p. 223-240.

Brovarone, A. V., and Agard, P., 2013, True metamorphic isograds or tectonically sliced metamorphic sequence? New high-spatial resolution petrological data for the New Caledonia case study: Contributions to Mineralogy and Petrology, v. 166, no. 2, p. 451-469.

Brun, J.-P., 1983, L'origine des domes gneissiques; modeles et tests: Bulletin de la Société géologique de France, v. 7, no. 2, p. 219-228.

Brun, J.-P., 2002, Deformation of the continental lithosphere: Insights from brittle-ductile models: Geological Society, London, Special Publications, v. 200, no. 1, p. 355 370 . 
Brun, J.-P., and Faccenna, C., 2008, Exhumation of high-pressure rocks driven by slab rollback: Earth and Planetary Science Letters, v. 272, no. 1, p. 1-7.

Brun, J.-P., Faccenna, C., Gueydan, F., Sokoutis, D., Philippon, M., Kydonakis, K., and Gorini, C., 2016, The two-stage Aegean extension, from localized to distributed, a result of slab rollback acceleration 1: Canadian journal of earth sciences, v. 53, no. 11, p. 1142-1157.

Brun, J.-P., and Sokoutis, D., 2007, Kinematics of the southern Rhodope core complex (North Greece): International Journal of Earth Sciences, v. 96, no. 6, p. 1079-1099.

Brun, J.-P., and Sokoutis, D., 2010, 45 my of Aegean crust and mantle flow driven by trench retreat: Geology, v. 38, no. 9, p. 815-818.

Brun, J.-P., Sokoutis, D., Tirel, C., Gueydan, F., Van den Driessche, J., and Beslier, M.-O., 2018, Crustal versus mantle core complexes: Tectonophysics, v. 746, p. 22-45.

Brun, J.-P., Sokoutis, D., and Van Den Driessche, J., 1994, Analogue modeling of detachment fault systems and core complexes: Geology, v. 22, no. 4, p. 319-322.

Brun, J. P., 1999, Narrow rifts versus wide rifts: inferences for the mechanics of rifting from laboratory experiments: Philosophical Transactions of the Royal Society of London. Series A: Mathematical, Physical and Engineering Sciences, v. 357, no. 1753, p. 695-712.

Brun, J. P., and Sokoutis, D., 2018, Core complex segmentation in North Aegean, a dynamic view: Tectonics, v. 37, no. 6, p. 1797-1830.

Brunet, C., Monié, P., Jolivet, L., and Cadet, J.-P., 2000, Migration of compression and extension in the Tyrrhenian Sea, insights from 40Ar/39Ar ages on micas along a transect from Corsica to Tuscany: Tectonophysics, v. 321, no. 1, p. 127-155.

Brunn, J., Argyriadis, I., Ricou, L., Poisson, A., Marcoux, J., and De Graciansky, P., 1976, Eléments majeurs de liaison entre Taurides et Hellénides: Bulletin de la Societé géologique de France, v. 7, no. 2, p. 481-497.

Burg, J.-P., 2012, Rhodope: From Mesozoic convergence to Cenozoic extension: Journal of the Virtual Explorer, v. 42, p. 1.

Carosi, R., Cortesogno, L., Gaggero, L. t., and Marroni, M., 1996, Geological and petrological features of the metamorphic sole from the Mirdita nappe, northern Albania: Ofioliti, v. 21, no. 1, p. 21-40.

Carter, N. L., and Tsenn, M. C., 1987, Flow properties of continental lithosphere: Tectonophysics, v. 136, no. 1-2, p. 27-63.

Chemenda, A., Matte, P., and Sokolov, V., 1997, A model of Palaeozoic obduction and exhumation of high-pressure/low-temperature rocks in the southern Urals: Tectonophysics, v. 276, no. 1-4, p. 217-227.

Chemenda, A. I., Mattauer, M., and Bokun, A. N., 1996, Continental subduction and a mechanism for exhumation of high-pressure metamorphic rocks: new modelling and field data from Oman: Earth and Planetary Science Letters, v. 143, no. 1-4, p. 173-182.

Chertova, M., Spakman, W., Geenen, T., Van Den Berg, A., and Van Hinsbergen, D., 2014, Underpinning tectonic reconstructions of the western Mediterranean region with dynamic slab evolution from 3-D numerical modeling: Journal of Geophysical Research: Solid Earth, v. 119, no. 7, p. 5876-5902.

Clift, P., and Vannucchi, P., 2004, Controls on tectonic accretion versus erosion in subduction zones: Implications for the origin and recycling of the continental crust: Reviews of Geophysics, v. 42, no. 2.

Clift, P. D., and Dixon, J., 1998, Jurassic ridge collapse, subduction initiation and ophiolite obduction in the southern Greek Tethys: Eclogae Geologicae Helvetiae, v. 91, p. 123-138. 
Clift, P. D., and Robertson, A. H., 1989, Evidence of a late Mesozoic ocean basin and subduction-accretion in the southern Greek Neo-Tethys: Geology, v. 17, no. 6, p. 559-563.

Cloos, M., and Shreve, R. L., 1988, Subduction-channel model of prism accretion, melange formation, sediment subduction, and subduction erosion at convergent plate margins: 1. Background and description: Pure and Applied Geophysics, v. 128, no. 3-4, p. 455-500.

Coleman, R., 1971, Plate tectonic emplacement of upper mantle peridotites along continental edges: Journal of Geophysical Research, v. 76, no. 5, p. 1212-1222.

Comas, M., Platt, J., Soto, J., and Watts, A., 44. The origin and tectonic history of the Alboran Basin: insights from Leg 161 results, in Proceedings Proceedings of the Ocean Drilling Program Scientific Results1999, Volume 161, p. 555-580.

Connolly, J., 2009, The geodynamic equation of state: what and how: Geochemistry, Geophysics, Geosystems, v. 10, no. 10.

Connolly, J. A., 2005, Computation of phase equilibria by linear programming: a tool for geodynamic modeling and its application to subduction zone decarbonation: Earth and Planetary Science Letters, v. 236, no. 1-2, p. 524-541.

Crameri, F., 2018, Scientific colour-maps: Zenodo. doi, v. 10.

Dahlen, F., 1990, Critical taper model of fold-and-thrust belts and accretionary wedges: Annual Review of Earth and Planetary Sciences, v. 18, no. 1, p. 55-99.

Danelian, T., and Robertson, A. H., 2001, Neotethyan evolution of eastern Greece (Pagondas Melange, Evia island) inferred from radiolarian biostratigraphy and the geochemistry of associated extrusive rocks: Geological Magazine, v. 138, no. 3, p. 345-363.

Daniel, J.-M., Jolivet, L., Goffe, B., and Poinssot, C., 1996, Crustal-scale strain partitioning: footwall deformation below the Alpine Oligo-Miocene detachment of Corsica: Journal of Structural Geology, v. 18, no. 1, p. 41-59.

De Bono, A., 1998, Pelagonian Margins in central Evia island (Greece): stratigraphy and geodynamic evolution: Université de Lausanne.

De Bono, A., Martini, R., Zaninetti, L., Hirsch, F., Stampfli, G. M., and Vavassis, I., 2001, Permo-Triassic stratigraphy of the pelagonian zone in central Evia island (Greece): Eclogae Geologicae Helvetiae, v. 94, p. 289-311.

De Bresser, J., 2002, On the mechanism of dislocation creep of calcite at high temperature: Inferences from experimentally measured pressure sensitivity and strain rate sensitivity of flow stress: Journal of Geophysical Research: Solid Earth, v. 107, no. B12, p. ECV 4-1-ECV 4-16.

de Jong, K., 2003, Very fast exhumation of high-pressure metamorphic rocks with excess 40Ar and inherited 87Sr, Betic Cordilleras, southern Spain: Lithos, v. 70, no. 3-4, p. 91-110.

de Jong, K., Féraud, G., Ruffet, G., Amouric, M., and Wijbrans, J., 2001, Excess argon incorporation in phengite of the Mulhacén Complex: submicroscopic illitization and fluid ingress during late Miocene extension in the Betic Zone, south-eastern Spain: Chemical Geology, v. 178, no. 1-4, p. 159-195.

de Jong, K., Wijbrans, J. R., and Féraud, G., 1992, Repeated thermal resetting of phengites in the Mulhacen Complex (Betic Zone, southeastern Spain) shown by40Ar/39Ar step heating and single grain laser probe dating: Earth and Planetary Science Letters, v. 110 , no. 1-4, p. 173-191.

Dewey, J., 1976, Ophiolite obduction: Tectonophysics, v. 31, no. 1-2, p. 93-120.

Dewey, J., 1988, Extensional collapse of orogens: Tectonics, v. 7, no. 6, p. 1123-1139. 
Dewey, J. F., and Bird, J. M., 1970, Mountain belts and the new global tectonics: Journal of geophysical Research, v. 75, no. 14, p. 2625-2647.

Dilek, Y., Furnes, H., and Shallo, M., 2007, Suprasubduction zone ophiolite formation along the periphery of Mesozoic Gondwana: Gondwana Research, v. 11, no. 4, p. 453 475.

Dimo-Lahitte, A., Monié, P., and Vergély, P., 2001, Metamorphic soles from the Albanian ophiolites: Petrology, 40Ar/39Ar geochronology, and geodynamic evolution: Tectonics, v. 20, no. 1, p. 78-96.

Dinter, D. A., and Royden, L., 1993, Late Cenozoic extension in northeastern Greece: Strymon Valley detachment system and Rhodope metamorphic core complex: Geology, v. 21, no. 1, p. 45-48.

Dobretsov, N., 1991, Blueschists and eclogites: a possible plate tectonic mechanism for their emplacement from the upper mantle: Tectonophysics, v. 186, no. 3-4, p. 253-268.

Duretz, T., Agard, P., Yamato, P., Ducassou, C., Burov, E. B., and Gerya, T. V., 2016a, Thermo-mechanical modeling of the obduction process based on the Oman ophiolite case: Gondwana Research, v. 32, p. 1-10.

Duretz, T., May, D. A., and Yamato, P., 2016b, A free surface capturing discretization for the staggered grid finite difference scheme: Geophysical Journal International, v. 204, no. 3, p. 1518-1530.

Duretz, T., Petri, B., Mohn, G., Schmalholz, S., Schenker, F., and Müntener, O., 2016c, The importance of structural softening for the evolution and architecture of passive margins: Scientific reports, v. 6, no. 1, p. 1-7.

Duretz, T., Schmalholz, S., and Podladchikov, Y., 2015, Shear heating-induced strain localization across the scales: Philosophical Magazine, v. 95, no. 28-30, p. 31923207.

Evans, B., and Goetze, C., 1979, The temperature variation of hardness of olivine and its implication for polycrystalline yield stress: Journal of Geophysical Research: Solid Earth, v. 84, no. B10, p. 5505-5524.

Faccenna, C., Becker, T. W., Auer, L., Billi, A., Boschi, L., Brun, J. P., Capitanio, F. A., Funiciello, F., Horvàth, F., and Jolivet, L., 2014, Mantle dynamics in the Mediterranean: Reviews of Geophysics, v. 52, no. 3, p. 283-332.

Faccenna, C., Piromallo, C., Crespo-Blanc, A., Jolivet, L., and Rossetti, F., 2004, Lateral slab deformation and the origin of the western Mediterranean arcs: Tectonics, v. 23, no. 1.

Farr, T. G., Rosen, P. A., Caro, E., Crippen, R., Duren, R., Hensley, S., Kobrick, M., Paller, M., Rodriguez, E., and Roth, L., 2007, The shuttle radar topography mission: Reviews of geophysics, v. 45, no. 2.

Faupl, P., Pavlopoulos, A., and Migiros, G., 1999, The Paleogene history of the Pelagonian zone SL (Hellenides, Greece): Heavy mineral study from terrigenous flysch sediments: Geologica Carpathica, v. 50, no. 6, p. 449-458.

Ferentinos, G. C., 1973, The geology-petrology of the island of Skiathos: $\Delta \varepsilon \lambda \tau i$ ov $\tau \eta \varsigma$

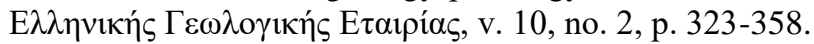

Franke, D., 2013, Rifting, lithosphere breakup and volcanism: Comparison of magma-poor and volcanic rifted margins: Marine and Petroleum geology, v. 43, p. 63-87.

Frisch, W., Dunkl, I., and Kuhlemann, J., 2000, Post-collisional orogen-parallel large-scale extension in the Eastern Alps: Tectonophysics, v. 327, no. 3-4, p. 239-265.

Froitzheim, N., Pleuger, J., Roller, S., and Nagel, T., 2003, Exhumation of high-and ultrahigh-pressure metamorphic rocks by slab extraction: Geology, v. 31, no. 10, p. 925-928. 
García-Casco, A., Iturralde-Vinent, M. A., and Pindell, J., 2008, Latest Cretaceous collision/accretion between the Caribbean Plate and Caribeana: origin of metamorphic terranes in the Greater Antilles: International Geology Review, v. 50, no. 9, p. 781-809.

García-Dueñas, V., Balanyá, J., and Martínez-Martínez, J., 1992, Miocene extensional detachments in the outcropping basement of the northern Alboran basin (Betics) and their tectonic implications: Geo-Marine Letters, v. 12, no. 2-3, p. 88-95.

García-Dueñas, V., Martinez Martinez, J., Orozco, M., and Soto, J., 1988, Plis-nappes, cisaillements syn-à post-métamorphiques et cisaillement ductiles-fragiles en distension dans les Nevado-Filábrides (Cordillères Bétiques, Espagne): Comptes rendus de l'Académie des sciences. Série 2, Mécanique, Physique, Chimie, Sciences de l'univers, Sciences de la Terre, v. 307, no. 11, p. 1389-1395.

García-Casco, A., Torres-Roldán, R., Millán, G., Monié, P., and Haissen, F., 2001, Highgrade metamorphism and hydrous melting of metapelites in the Pinos terrane (W Cuba): Evidence for crustal thickening and extension in the northern Caribbean collisional belt: Journal of Metamorphic Geology, v. 19, no. 6, p. 699-715.

Garcia Monzón, G., Kampschuur, W., and Verburg, J., 1974, Mapa geologico de Espana,Hoja 1031, Sorbas. Instituto Geologico y Minero de Espana (IGME), Ministerio deIndustria y Energía. Madrid, scale 1:50000.

Gautier, P., and Brun, J.-P., 1994, Crustal-scale geometry and kinematics of late-orogenic extension in the central Aegean (Cyclades and Ewia Island): Tectonophysics, v. 238, no. 1-4, p. 399-424.

Gawlick, H.-J., Sudar, M., Suzuki, H., Deric, N., Missoni, S., Lein, R., and Jovanović, D., 2009, Upper Triassic and Middle Jurassic radiolarians from the ophiolitic mélange of the Dinaridic Ophiolite Belt, SW Serbia: Neues Jahrbuch für Geologie und Paläontologie-Abhandlungen, v. 253, no. 2-3, p. 293-311.

Gealey, W., 1977, Ophiolite obduction and geologic evolution of the Oman Mountains and adjacent areas: Geological Society of America Bulletin, v. 88, no. 8, p. 1183-1191.

Gerogiannis, N., and Xypolias, P., 2017, Retroward extrusion of high-pressure rocks: An example from the Hellenides (Pelion Blueschist Nappe, NW Aegean): Terra Nova, v. 29 , no. 6 , p. 372-381.

Gerya, T. V., and Yuen, D. A., 2003, Characteristics-based marker-in-cell method with conservative finite-differences schemes for modeling geological flows with strongly variable transport properties: Physics of the Earth and Planetary Interiors, v. 140, no. 4, p. 293-318.

Glodny, J., Bingen, B., Austrheim, H., Molina, J. F., and Rusin, A., 2002, Precise eclogitization ages deduced from $\mathrm{Rb} / \mathrm{Sr}$ mineral systematics: the Maksyutov complex, Southern Urals, Russia: Geochimica et Cosmochimica Acta, v. 66, no. 7, p. 1221-1235.

Glodny, J., Kühn, A., and Austrheim, H., 2008, Geochronology of fluid-induced eclogite and amphibolite facies metamorphic reactions in a subduction-collision system, Bergen Arcs, Norway: Contributions to Mineralogy and Petrology, v. 156, no. 1, p. 27-48.

Goffé, B., Goffé-Urbano, G., and Saliot, P., 1973, Sur la présence d'une variété magnésienne de la ferrocarpholite en Vanoise (Alpes françaises): sa signification probable dans le métamorphisme alpin: Comptes Rendus de l'Académie des Sciences Paris, v. 277, p. 1965-1968.

Goffé, B., Michard, A., Garcia-Duenas, V., Gonzalez-Lodeiro, F., Monie, P., Campos, J., Galindo-Zaldivar, J., Jabaloy, A., Martinez-Martinez, J. M., and Simancas, J. F., 1989, First evidence of high-pressure, low-temperature metamorphism in the 
Alpujarride nappes, Betic Cordilleras (SE Spain): European Journal of Mineralogy, p. 139-142.

Goffé, B., Michard, A., Kienast, J. R., and Le Mer, O., 1988, A case of obduction-related high-pressure, low-temperature metamorphism in upper crustal nappes, Arabian continental margin, Oman: PT paths and kinematic interpretation: Tectonophysics, v. 151 , no. $1-4$, p. $363-386$.

Gomez-Pugnaire, M. T., and Munoz, M., 1991, Al-rich xenoliths in the Nevado-Filábride metabasites: evidence for a continental setting of this basic magmatism in the Betic Cordilleras (SE Spain): European Journal of Mineralogy, p. 193-198.

Gottschalk, R. R., and Oldow, J. S., 1988, Low-angle normal faults in the south-central Brooks Range fold and thrust belt, Alaska: Geology, v. 16, no. 5, p. 395-399.

Grasemann, B., Schneider, D. A., Stöckli, D. F., and Iglseder, C., 2012, Miocene bivergent crustal extension in the Aegean: Evidence from the western Cyclades (Greece): Lithosphere, v. 4, no. 1, p. 23-39.

Hacker, B. R., Ratschbacher, L., Webb, L., McWilliams, M. O., Ireland, T., Calvert, A., Dong, S., Wenk, H. R., and Chateigner, D., 2000, Exhumation of ultrahigh-pressure continental crust in east central China: Late Triassic-Early Jurassic tectonic unroofing: Journal of Geophysical Research: Solid Earth, v. 105, no. B6, p. 1333913364.

Handy, M. R., Schmid, S. M., Bousquet, R., Kissling, E., and Bernoulli, D., 2010, Reconciling plate-tectonic reconstructions of Alpine Tethys with the geologicalgeophysical record of spreading and subduction in the Alps: Earth-Science Reviews, v. 102 , no. 3-4, p. 121-158.

Hansen, F., and Carter, N., Semibrittle creep of dry and wet Westerly granite at $1000 \mathrm{MPa}$, in Proceedings The 24th US Symposium on Rock Mechanics (USRMS)1983, American Rock Mechanics Association.

Harris, R., 1992, Peri-collisional extension and the formation of Oman-type ophiolites in the Banda Arc and Brooks Range: Geological Society, London, Special Publications, v. 60, no. 1, p. 301-325.

Harrison, T. M., Célérier, J., Aikman, A. B., Hermann, J., and Heizler, M. T., 2009, Diffusion of 40Ar in muscovite: Geochimica et Cosmochimica Acta, v. 73, no. 4, p. 10391051.

Hässig, M., Rolland, Y., Duretz, T., and Sosson, M., 2016, Obduction triggered by regional heating during plate reorganization: Terra Nova, v. 28, no. 1, p. 76-82.

Hässig, M., Rolland, Y., Sosson, M., Galoyan, G., Müller, C., Avagyan, A., and Sahakyan, L., 2013, New structural and petrological data on the Amasia ophiolites (NW Sevan-Akera suture zone, Lesser Caucasus): insights for a large-scale obduction in Armenia and NE Turkey: Tectonophysics, v. 588, p. 135-153.

Heinitz, W., and Richter-Heinitz, I., 1983, Geologische Unteersuchungen im Nordost-Teil der Insel Skiathos (Griechenland): Berliner geowissenschaftliche Abhandlungen,(A), v. 48, p. 41-63.

Hejl, E., Riedl, H., and Weingartner, H., 1999, Cretaceous palaeokarst and Cenozoic erosion of the North Sporades (Greece): Results from geomorphological studies and fissiontrack analysis: Mitt. Oesterr. Geol. Ges, v. 90, p. 67-82.

Herwegh, M., Berger, A., Baumberger, R., Wehrens, P., and Kissling, E., 2017, Large-scale crustal-block-extrusion during late Alpine collision: Scientific reports, v. 7, no. 1, p. 1-10.

Hetényi, G., Molinari, I., Clinton, J., Bokelmann, G., Bondár, I., Crawford, W. C., Dessa, J.X., Doubre, C., Friederich, W., and Fuchs, F., 2018, The AlpArray seismic network: 
a large-scale European experiment to image the Alpine orogen: Surveys in geophysics, v. 39, no. 5, p. 1009-1033.

Hilairet, N., Reynard, B., Wang, Y., Daniel, I., Merkel, S., Nishiyama, N., and Petitgirard, S., 2007, High-pressure creep of serpentine, interseismic deformation, and initiation of subduction: Science, v. 318, no. 5858, p. 1910-1913.

Hirth, G., and Kohlstedf, D., 2003, Rheology of the upper mantle and the mantle wedge: A view from the experimentalists: GEOPHYSICAL MONOGRAPH-AMERICAN GEOPHYSICAL UNION, v. 138, p. 83-106.

Hoiland, C. W., Miller, E. L., and Pease, V., 2018, Greenschist facies metamorphic zircon overgrowths as a constraint on exhumation of the brooks range metamorphic core, Alaska: Tectonics, v. 37, no. 10, p. 3429-3455.

Jabaloy-Sánchez, A., Talavera, C., Gómez-Pugnaire, M. T., López-Sánchez-Vizcaíno, V., Vázquez-Vílchez, M., Rodríguez-Peces, M. J., and Evans, N. J., 2018, U-Pb ages of detrital zircons from the Internal Betics: A key to deciphering paleogeographic provenance and tectono-stratigraphic evolution: Lithos, v. 318, p. 244-266.

Jabaloy-Sánchez, A., Talavera, C., Rodríguez-Peces, M. J., Vázquez-Vílchez, M., and Evans, N. J., 2021, U-Pb geochronology of detrital and igneous zircon grains from the Águilas Arc in the Internal Betics (SE Spain): Implications for CarboniferousPermian paleogeography of Pangea: Gondwana Research, v. 90, p. 135-158.

Jacobshagen, V., 1978, Structure and geodynamic evolution of the Aegean region.

Jacobshagen, V., and Matarangas, D., 2004, Nappe structure of the North Sporades (Greece):

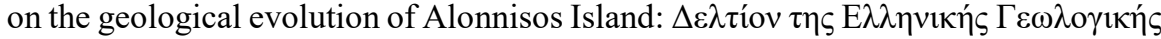

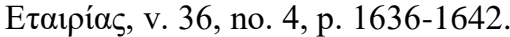

Jacobshagen, V., Skala, W., and Wallbrecher, E., 1978, Alpine structure and development of the southern Pelion peninsula and the North Sporades: Alps, Apennines, Hellenides Sci Report, v. 38, p. 484-488.

Jacobshagen, V., and Wallbrecher, E., 1984, Pre-Neogene nappe structure and metamorphism of the North Sporades and the southern Pelion peninsula: Geological Society, London, Special Publications, v. 17, no. 1, p. 591-602.

Jahn-Awe, S., Froitzheim, N., Nagel, T. J., Frei, D., Georgiev, N., and Pleuger, J., 2010, Structural and geochronological evidence for Paleogene thrusting in the western Rhodopes, SW Bulgaria: elements for a new tectonic model of the Rhodope Metamorphic Province: Tectonics, v. 29, no. 3.

Johnson, C., 1997, Resolving denudational histories in orogenic belts with apatite fissiontrack thermochronology and structural data: An example from southern Spain: Geology, v. 25, no. 7, p. 623-626.

Jolivet, L., and Brun, J.-P., 2010, Cenozoic geodynamic evolution of the Aegean: International Journal of Earth Sciences, v. 99, no. 1, p. 109-138.

Jolivet, L., Faccenna, C., Goffé, B., Burov, E., and Agard, P., 2003, Subduction tectonics and exhumation of high-pressure metamorphic rocks in the Mediterranean orogens: American Journal of Science, v. 303, no. 5, p. 353-409.

Jolivet, L., Lecomte, E., Huet, B., Denèle, Y., Lacombe, O., Labrousse, L., Le Pourhiet, L., and Mehl, C., 2010, The north cycladic detachment system: Earth and Planetary Science Letters, v. 289, no. 1-2, p. 87-104.

Jolivet, L., Menant, A., Clerc, C., Sternai, P., Bellahsen, N., Leroy, S., Pik, R., Stab, M., Faccenna, C., and Gorini, C., 2018, Extensional crustal tectonics and crust-mantle coupling, a view from the geological record: Earth-Science Reviews, v. 185, p. 1187-1209.

Jongsma, D., 1975, A marine geophysical study of the Hellenic Arc: University of Cambridge. 
Kameyama, M., Yuen, D. A., and Karato, S.-I., 1999, Thermal-mechanical effects of lowtemperature plasticity (the Peierls mechanism) on the deformation of a viscoelastic shear zone: Earth and Planetary Science Letters, v. 168, no. 1-2, p. 159-172.

Keep, M., and Haig, D. W., 2010, Deformation and exhumation in Timor: Distinct stages of a young orogeny: Tectonophysics, v. 483, no. 1-2, p. 93-111.

Kelepertsis, A., 1974, Geological structure of Alonnisos and Peristera islands (Aegaean Sea, Greece): Zeitschrift der Deutschen Geologischen Gesellschaft, p. 225-236.

Keller, J., Minelli, G., and Pialli, G., 1994, Anatomy of late orogenic extension: the Northern Apennines case: Tectonophysics, v. 238, no. 1-4, p. 275-294.

Kilias, A., Frisch, W., Avgerinas, A., Dunkl, I., Falalakis, G., and Gawlick, H.-J., 2010, Alpine architecture and kinematics of deformation of the northern Pelagonian nappe pile in the Hellenides.

Kilias, A., Kasselas, G., and Nastos, G., 1990, Quartz c-axis fabrics as a kinematic indicator of sense of nappe emplacement - an example from the NE Pieria mountain area (Greece): Zeitschrift für Angewandte Geologische, v. 36, no. 11, p. 427-433.

Kirchner, K. L., Behr, W. M., Loewy, S., and Stockli, D. F., 2016, Early Miocene subduction in the western Mediterranean: Constraints from $\mathrm{Rb}-\mathrm{Sr}$ multimineral isochron geochronology: Geochemistry, Geophysics, Geosystems, v. 17, no. 5, p. 1842-1860.

Kiss, D., Duretz, T., and Schmalholz, S., 2020, Tectonic inheritance controls nappe detachment, transport and stacking in the Helvetic Nappe System, Switzerland: insights from thermo-mechanical simulations: Solid Earth, v. 11, no. 2, p. 287-305.

Kiss, D., Podladchikov, Y., Duretz, T., and Schmalholz, S. M., 2019, Spontaneous generation of ductile shear zones by thermal softening: Localization criterion, 1D to 3D modelling and application to the lithosphere: Earth and Planetary Science Letters, v. 519, p. 284-296.

Koch, P. S., Christie, J. M., Ord, A., and George Jr, R. P., 1989, Effect of water on the rheology of experimentally deformed quartzite: Journal of Geophysical Research: Solid Earth, v. 94, no. B10, p. 13975-13996.

Koppers, A. A., 2002, ArArCALC - software for 40 Ar/39 Ar age calculations: Computers \& Geosciences, v. 28, no. 5, p. 605-619.

Koroneos, A., Christofides, G., Del Moro, A., and Kilias, A., 1993, Rb-Sr geochronology and geochemical aspects of the Eastern Varnountas plutonite (NW Macedonia, Greece): Neues Jahrbuch für Mineralogie, Abhandlungen, v. 165, no. 3, p. 297-315.

Kronenberg, A. K., Kirby, S. H., and Pinkston, J., 1990, Basal slip and mechanical anisotropy of biotite: Journal of Geophysical Research: Solid Earth, v. 95, no. B12, p. 1925719278.

Kuiper, K., Deino, A., Hilgen, F., Krijgsman, W., Renne, P., Wijbrans, and JR, 2008, Synchronizing rock clocks of Earth history: science, v. 320, no. 5875, p. 500-504.

Kydonakis, K., Brun, J.-P., Poujol, M., Monié, P., and Chatzitheodoridis, E., 2016, Inferences on the Mesozoic evolution of the North Aegean from the isotopic record of the Chalkidiki block: Tectonophysics, v. 682, p. 65-84.

Laborda-López, C., Marchesi, C., Sánchez-Vizcaíno, V. L., Gómez-Pugnaire, M. T., Dale, C. W., Jabaloy-Sánchez, A., Padrón-Navarta, J. A., Román-Alpiste, M. J., and Garrido, C. J., 2020, Geochemical evolution of rodingites during subduction: insights from Cerro del Almirez (southern Spain): Lithos, v. 370, p. 105639.

Lagabrielle, Y., Chauvet, A., Ulrich, M., and Guillot, S., 2013, Passive obduction and gravity-driven emplacement of large ophiolitic sheets: The New Caledonia ophiolite (SW Pacific) as a case study?: Bulletin de la Société géologique de France, v. 184, no. 6 , p. 545-556. 
Laurent, V., Huet, B., Labrousse, L., Jolivet, L., Monie, P., and Augier, R., 2017, Extraneous argon in high-pressure metamorphic rocks: Distribution, origin and transport in the Cycladic Blueschist Unit (Greece): Lithos, v. 272, p. 315-335.

Le Pichon, X., Angelier, J., Osmaston, M., and Stegena, L., 1981, The Aegean Sea [and Discussion]: Philosophical Transactions of the Royal Society of London A: Mathematical, Physical and Engineering Sciences, v. 300, no. 1454, p. 357-372.

Lefebvre, C., Peters, M. K., Wehrens, P. C., Brouwer, F. M., and van Roermund, H. L., 2015, Thermal history and extensional exhumation of a high-temperature crystalline complex (Hırkadağ Massif, Central Anatolia): Lithos, v. 238, p. 156-173.

Li, B., and Massonne, H. J., 2018, Two Tertiary metamorphic events recognized in highpressure metapelites of the Nevado-Filábride Complex (Betic Cordillera, S Spain): Journal of Metamorphic Geology, v. 36, no. 5, p. 603-630.

Liati, A., Gebauer, D., and Fanning, C. M., 2004, The age of ophiolitic rocks of the Hellenides (Vourinos, Pindos, Crete): first U-Pb ion microprobe (SHRIMP) zircon ages: Chemical Geology, v. 207, no. 3, p. 171-188.

Lips, A., White, S., and Wijbrans, J., 1998, 40 Ar/39 Ar laserprobe direct dating of discrete deformational events: a continuous record of early Alpine tectonics in the Pelagonian Zone, NW Aegean area, Greece: Tectonophysics, v. 298, no. 1, p. 133 153.

Lips, A., Wijbrans, J., and White, S., 1999, New insights from 40Ar/39Ar laserprobe dating of white mica fabrics from the Pelion Massif, Pelagonian Zone, Internal Hellenides, Greece: implications for the timing of metamorphic episodes and tectonic events in the Aegean region: Geological Society, London, Special Publications, v. 156, no. 1, p. 457-474.

Lips, A. L., White, S. H., and Wijbrans, J. R., 2000, Middle-late Alpine thermotectonic evolution of the southern Rhodope Massif, Greece: Geodinamica Acta, v. 13, no. 5, p. 281-292.

Lister, G., and Forster, M., 2016, White mica 40Ar/39Ar age spectra and the timing of multiple episodes of high-P metamorphic mineral growth in the Cycladic eclogiteblueschist belt, Syros, Aegean Sea, Greece: Journal of Metamorphic Geology, v. 34, no. 5, p. 401-421.

Lister, G. S., Banga, G., and Feenstra, A., 1984, Metamorphic core complexes of Cordilleran type in the Cyclades, Aegean Sea, Greece: Geology, v. 12, no. 4, p. 221-225.

Lister, G. S., and Davis, G. A., 1989, The origin of metamorphic core complexes and detachment faults formed during Tertiary continental extension in the northern Colorado River region, USA: 11, p. 65-94.

Lonergan, L., and Johnson, C., 2002, Reconstructing orogenic exhumation histories using synorogenic detrital zircons and apatites: an example from the Betic Cordillera, SE Spain: Basin Research, v. 10, no. 3, p. 353-364.

Lonergan, L., and White, N., 1997, Origin of the Betic-Rif mountain belt: Tectonics, v. 16, no. 3, p. 504-522.

Maffione, M., Thieulot, C., Van Hinsbergen, D. J., Morris, A., Plümper, O., and Spakman, W., 2015, Dynamics of intraoceanic subduction initiation: 1. Oceanic detachment fault inversion and the formation of supra-subduction zone ophiolites: Geochemistry, Geophysics, Geosystems, v. 16, no. 6, p. 1753-1770.

Maffione, M., and van Hinsbergen, D. J., 2018, Reconstructing plate boundaries in the Jurassic neo-Tethys from the east and west Vardar ophiolites (Greece and Serbia): Tectonics, v. 37 , no. 3 , p. 858-887.

Maffione, M., van Hinsbergen, D. J., de Gelder, G. I., van der Goes, F. C., and Morris, A., 2017, Kinematics of Late Cretaceous subduction initiation in the Neo-Tethys Ocean 
reconstructed from ophiolites of Turkey, Cyprus, and Syria: Journal of Geophysical Research: Solid Earth, v. 122, no. 5, p. 3953-3976.

Martínez-Martínez, J., Torres-Ruiz, J., Pesquera, A., and Gil-Crespo, P., 2010, Geological relationships and $\mathrm{U}-\mathrm{Pb}$ zircon and $40 \mathrm{Ar} / 39 \mathrm{Ar}$ tourmaline geochronology of gneisses and tourmalinites from the Nevado-Filabride complex (western Sierra Nevada, Spain): tectonic implications: Lithos, v. 119, no. 3-4, p. 238-250.

Martínez-Martínez, J., and Azañón, J., 1997, Mode of extensional tectonics in the southeastern Betics (SE Spain): Implications for the tectonic evolution of the periAlborán orogenic system: Tectonics, v. 16, no. 2, p. 205-225.

Martínez-Martínez, J., Soto, J., and Balanyá, J., 2002, Orthogonal folding of extensional detachments: structure and origin of the Sierra Nevada elongated dome (Betics, SE Spain): Tectonics, v. 21, no. 3, p. 3-1-3-20.

Martínez Martínez, J., 1984, Las sucesiones Nevado-Filabrides en la Sierra de los Filabres y Sierra Nevada. Correlaciones.

Martínez Martínez, J. M., 1986, Evolución tectóno-metamórfica del Complejo NevadoFilábride en el sector de unión entre Sierra Nevada y Sierra de los Filabres (Cordilleras Béticas).

Mascle, J., and Martin, L., 1990, Shallow structure and recent evolution of the Aegean Sea: a synthesis based on continuous reflection profiles: Marine Geology, v. 94, no. 4, p. 271-299.

Matarangas, D., 1992, Geological investigation of Skopelos island, North Sporades, Greece, Forschungszentrum Jülich, Zentralbibliothek.

Matenco, L., and Schmid, S., 1999, Exhumation of the Danubian nappes system (South Carpathians) during the Early Tertiary: inferences from kinematic and paleostress analysis at the Getic/Danubian nappes contact: Tectonophysics, v. 314, no. 4, p. 401-422.

Maurizot, P., Robineau, B., Vendé-Leclerc, M., and Cluzel, D., 2020, Introduction to New Caledonia: geology, geodynamic evolution and mineral resources, Geological Society of London.

Meffre, S., Aitchison, J. C., and Crawford, A. J., 1996, Geochemical evolution and tectonic significance of boninites and tholeiites from the Koh ophiolite, New Caledonia: Tectonics, v. 15, no. 1, p. 67-83.

Mercier, J., Vergely, P., and Bebien, J., 1975, Les ophiolites helléniques «obductées» au Jurassique supérieur sont-elles les vestiges d'un Océan téthysien ou d'une mer marginale périeuropéenne: Comptes Rendes Sommaires de la Société Géologique de France, v. 17, p. 108-111.

Milovanović, D., 1984, Petrology of low metamorphosed rocks of the central part of the Drina-Ivanjica Paleozoic: Bull. Mus. Hist. Nat. Belgrade, A, v. 39, p. 13-139.

Milovanovic, D., Marchig, V., and Stevan, K., 1995, Petrology of the crossite schist from Fruška Gora Mts (Yugoslavia), relic of a subducted slab of the Tethyan oceanic crust: Journal of Geodynamics, v. 20, no. 3, p. 289-304.

Monié, P., Galindo-Zaldivar, J., Lodeiro, F. G., Goffe, B., and Jabaloy, A., 1991, 40Ar/39Ar geochronology of Alpine tectonism in the Betic Cordilleras (southern Spain): Journal of the Geological Society, v. 148, no. 2, p. 289-297.

Monié, P., Torres-Roldán, R., and García-Casco, A., 1994, Cooling and exhumation of the Western Betic Cordilleras, 40Ar/39Ar thermochronological constraints on a collapsed terrane: Tectonophysics, v. 238, no. 1-4, p. 353-379.

Moresi, L., Dufour, F., and Mühlhaus, H.-B., 2003, A Lagrangian integration point finite element method for large deformation modeling of viscoelastic geomaterials: Journal of computational physics, v. 184, no. 2, p. 476-497. 
Morten, L., Bargossi, G., Martinez, J. M., Puga, E., and de Federico, A. D., 1987, Metagabbro and associated eclogites in the Lubrin area, Nevado-Filabride Complex, Spain: Journal of Metamorphic Geology, v. 5, no. 2, p. 155-174.

Most, T., 2003, Geodynamic evolution of the Eastern Pelagonian Zone in northwestern Greece and the Republic of Macedonia: Implications from U/Pb, $\mathrm{Rb} / \mathrm{Sr}, \mathrm{K} / \mathrm{Ar}$, $\mathrm{Ar} / \mathrm{Ar}$, geochronology and fission track thermochronology. Tubingen, Phd, Germany, p. 1-170.

Moulas, E., Burg, J.-P., and Podladchikov, Y., 2014, Stress field associated with elliptical inclusions in a deforming matrix: mathematical model and implications for tectonic overpressure in the lithosphere: Tectonophysics, v. 631, p. 37-49.

Moulas, E., Podladchikov, Y., Aranovich, L. Y., and Kostopoulos, D., 2013, The problem of depth in geology: When pressure does not translate into depth: Petrology, v. 21, no. 6, p. 527-538.

Moulas, E., Schmalholz, S. M., Podladchikov, Y., Tajčmanová, L., Kostopoulos, D., and Baumgartner, L., 2018, Relation between mean stress, thermodynamic, and lithostatic pressure: Journal of metamorphic geology.

Mposkos, E., and Liati, A., Fe-carpholite in chloritoid-bearing metapelites-metasandstones of Skopelos Island, N. Sporades, Greece, in Proceedings 5th Congress of the Geological Society of Greece. Deltio tes Ellenikes Geologikes Etaireias (Bulletin of the Geological Society of Greece)1991a, Volume 25, p. 55-66.

Mposkos, E., and Perraki, M., 2001, High pressure Alpine metamorphism of the Pelagonian allochthon in the Kastania area (Southern Vermion), Greece: Bulletin of the Geological Society of Greece, v. 34, no. 3, p. 939-947.

Mposkos, E., and Liati, A., 1991b, Fe-carpholite in chloritoid-bearing metapelites-

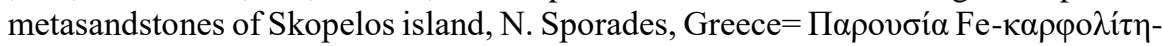

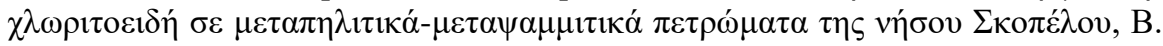

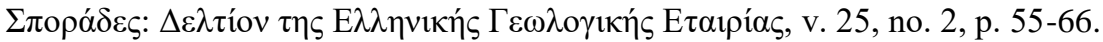

Oberhänsli, R., Goffe, B., Jolivet, L., and Vidal, O., 1998, High-pressure-low-temperature metamorphism and deformation in the Bündnerschiefer of the Engadine window: implications for the regional evolution of the eastern Central Alps: Journal of Metamorphic Geology, v. 16, no. 5, p. 657-674.

Okay, A., 2002, Jadeite-chloritoid-glaucophane-lawsonite blueschists in north-west Turkey: unusually high $\mathrm{P} / \mathrm{T}$ ratios in continental crust: Journal of Metamorphic Geology, v. 20, no. 8, p. 757-768.

Okay, A., Satır, M., Tüysüz, O., Akyüz, S., and Chen, F., 2001, The tectonics of the Strandja Massif: late-Variscan and mid-Mesozoic deformation and metamorphism in the northern Aegean: International Journal of Earth Sciences, v. 90, no. 2, p. 217-233.

Ortí, F., Pérez-López, A., and Salvany, J. M., 2017, Triassic evaporites of Iberia: Sedimentological and palaeogeographical implications for the western Neotethys evolution during the Middle Triassic-Earliest Jurassic: Palaeogeography, palaeoclimatology, palaeoecology, v. 471, p. 157-180.

Oxburgh, E., 1972, Flake tectonics and continental collision: Nature, v. 239, no. 5369, p. 202-204.

Padrón-Navarta, J. A., Hermann, J., Garrido, C. J., Sánchez-Vizcaíno, V. L., and GómezPugnaire, M. T., 2010, An experimental investigation of antigorite dehydration in natural silica-enriched serpentinite: Contributions to Mineralogy and Petrology, v. 159 , no. 1, p. 25.

Pascual, F. J. R., Arenas, R., Catalán, J. R. M., Fernández, L. R. R., and Wijbrans, J. R., 2013, Thickening and exhumation of the Variscan roots in the Iberian Central System: Tectonothermal processes and 40Ar/39Ar ages: Tectonophysics, v. 587, p. 207-221. 
Passchier, C. W., and Trouw, R. A., 1996, Microtectonics, Springer.

Patel, R., Singh, S., Asokan, A., Manickavasagam, R., and Jain, A., 1993, Extensional tectonics in the Himalayan orogen, Zanskar, NW India: Geological Society, London, Special Publications, v. 74, no. 1, p. 445-459.

Patriat, M., Collot, J., Etienne, S., Poli, S., Clerc, C., Mortimer, N., Pattier, F., Juan, C., Roest, W. R., and team, V. s. v., 2018, New Caledonia obducted Peridotite Nappe: offshore extent and implications for obduction and postobduction processes: Tectonics, v. 37, no. 4, p. 1077-1096.

Patrick, B., 1995, High-pressure-low-temperature metamorphism of granitic orthogneiss in the Brooks Range, northern Alaska: Journal of Metamorphic Geology, v. 13, no. 1, p. 111-124.

Pearce, J. A., Lippard, S., and Roberts, S., 1984, Characteristics and tectonic significance of supra-subduction zone ophiolites: Geological Society, London, Special Publications, v. 16, no. 1, p. 77-94.

Pedrera, A., Galindo-Zaldívar, J., Ruíz-Constán, A., Duque, C., Marín-Lechado, C., and Serrano, I., 2009, Recent large fold nucleation in the upper crust: Insight from gravity, magnetic, magnetotelluric and seismicity data (Sierra de Los FilabresSierra de Las Estancias, Internal Zones, Betic Cordillera): Tectonophysics, v. 463, no. 1-4, p. 145-160.

Pedrera, A., Ruiz-Constán, A., García-Senz, J., Azor, A., Marín-Lechado, C., Ayala, C., de Neira, J. A. D., and Rodríguez-Fernández, L. R., 2020, Evolution of the SouthIberian paleomargin: From hyperextension to continental subduction: Journal of Structural Geology, v. 138, p. 104122.

Philippon, M., Brun, J. P., and Gueydan, F., 2011, Tectonics of the Syros blueschists (Cyclades, Greece): From subduction to Aegean extension: Tectonics, v. 30, no. 4.

Plank, T., 2005, Constraints from thorium/lanthanum on sediment recycling at subduction zones and the evolution of the continents: Journal of Petrology, v. 46, no. 5, p. 921 944.

Platt, J., 1986, Dynamics of orogenic wedges and the uplift of high-pressure metamorphic rocks: Geological society of America bulletin, v. 97, no. 9, p. 1037-1053.

Platt, J., Allerton, S., Kirker, A., Mandeville, C., Mayfield, A., Platzman, E., and Rimi, A., 2003a, The ultimate arc: Differential displacement, oroclinal bending, and vertical axis rotation in the External Betic-Rif arc: Tectonics, v. 22, no. 3.

Platt, J., Behrmann, J., Martinez, J.-M., and Vissers, R., 1984, A zone of mylonite and related ductile deformation beneath the Alpujarride Nappe Complex, Betic Cordilleras, S. Spain: Geologische Rundschau, v. 73, no. 2, p. 773-785.

Platt, J., Kelley, S., Carter, A., and Orozco, M., 2005, Timing of tectonic events in the Alpujárride Complex, Betic Cordillera, southern Spain: Journal of the Geological Society, v. 162, no. 3, p. 451-462.

Platt, J., and Vissers, R., 1980, Extensional structures in anisotropic rocks: Journal of Structural Geology, v. 2, no. 4, p. 397-410.

Platt, J., and Vissers, R., 1989, Extensional collapse of thickened continental lithosphere: A working hypothesis for the Alboran Sea and Gibraltar arc: Geology, v. 17, no. 6, p. 540-543.

Platt, J., Whitehouse, M., Kelley, S., Carter, A., and Hollick, L., 2003b, Simultaneous extensional exhumation across the Alboran Basin: implications for the causes of late orogenic extension: Geology, v. 31, no. 3, p. 251-254.

Platt, J. P., Anczkiewicz, R., Soto, J.-I., Kelley, S. P., and Thirlwall, M., 2006, Early Miocene continental subduction and rapid exhumation in the western Mediterranean: Geology, v. 34, no. 11, p. 981-984. 
Plunder, A., Agard, P., Chopin, C., and Okay, A., Tectono-metamorphic evolution of the Tavsanli zone, Western Anatolia: implications for mechanical coupling during subduction/obduction processes, in Proceedings EGU General Assembly Conference Abstracts 2013, Volume 15.

Plunder, A., Agard, P., Chopin, C., Pourteau, A., and Okay, A. I., 2015, Accretion, underplating and exhumation along a subduction interface: from subduction initiation to continental subduction (Tavşanlı zone, W. Turkey): Lithos, v. 226, p. 233-254.

Plunder, A., Thieulot, C., and van Hinsbergen, D. J., 2018, The effect of obliquity on temperature in subduction zones: insights from 3-D numerical modeling: Solid Earth, v. 9, no. 3, p. 759-776.

Popov, A., and Sobolev, S. V., 2008, SLIM3D: A tool for three-dimensional thermomechanical modeling of lithospheric deformation with elasto-visco-plastic rheology: Physics of the earth and planetary interiors, v. 171, no. 1-4, p. 55-75.

Porkoláb, K., Duretz, T., Yamato, P., Auzemery, A., and Willingshofer, E., 2021, Extrusion of subducted crust explains the emplacement of far-travelled ophiolites: Nature communications, v. 12, no. 1, p. 1-11.

Porkoláb, K., Kövér, S., Benkó, Z., Héja, G. H., Fialowski, M., Soós, B., Spajić, N. G., Đerić, N., and Fodor, L., 2019a, Structural and geochronological constraints from the Drina-Ivanjica thrust sheet (Western Serbia): implications for the CretaceousPaleogene tectonics of the Internal Dinarides: Swiss Journal of Geosciences, v. 112(1), p. 217-234.

Porkoláb, K., Willingshofer, E., Sokoutis, D., Creton, I., Kostopoulos, D., and Wijbrans, J., 2019b, Cretaceous-Paleogene tectonics of the Pelagonian zone: Inferences from Skopelos island (Greece): Tectonics, v. 38, no. 6, p. 1946-1973.

Potel, S., Mählmann, R. F., Stern, W., Mullis, J., and Frey, M., 2006, Very low-grade metamorphic evolution of pelitic rocks under high-pressure/low-temperature conditions, NW New Caledonia (SW Pacific): Journal of Petrology, v. 47, no. 5, p. 991-1015.

Pourteau, A., Bousquet, R., Vidal, O., Plunder, A., Duesterhoeft, E., Candan, O., and Oberhänsli, R., 2014, Multistage growth of $\mathrm{Fe}-\mathrm{Mg}-$ carpholite and $\mathrm{Fe}-\mathrm{Mg}-$ chloritoid, from field evidence to thermodynamic modelling: Contributions to Mineralogy and Petrology, v. 168, no. 6, p. 1090.

Pourteau, A., Sudo, M., Candan, O., Lanari, P., Vidal, O., and Oberhänsli, R., 2013, Neotethys closure history of Anatolia: insights from 40Ar-39Ar geochronology and $\mathrm{P}-\mathrm{T}$ estimation in high-pressure metasedimentary rocks: Journal of Metamorphic Geology, v. 31, no. 6, p. 585-606.

Puga, E., 2005, A reappraisal of the Betic Ophiolitic Association: The westernmost relic of the Alpine Tethys Ocean: Deep Seismic Exploration of the Central Mediterranean and Italy. Italy, University of Trieste, Elsevier, Crosta Profonda (CROP), v. 1, p. 665-704.

Puga, E., De Federico, A. D., and Nieto, J. M., 2002, Tectonostratigraphic subdivision and petrological characterisation of the deepest complexes of the Betic zone: a review: Geodinamica Acta, v. 15, no. 1, p. 23-43.

Puga, E., Díaz de Federico, A., Fanning, M., Nieto, J. M., Rodríguez Martínez-Conde, J. Á., Díaz Puga, M. Á., Lozano, J. A., Bianchini, G., Natali, C., and Beccaluva, L., 2017, The Betic ophiolites and the Mesozoic evolution of the Western Tethys: Geosciences, v. 7, no. 2, p. 31.

Puga, E., Fanning, M., de Federico, A. D., Nieto, J. M., Beccaluva, L., Bianchini, G., and Puga, M. A. D., 2011, Petrology, geochemistry and U-Pb geochronology of the 
Betic Ophiolites: inferences for Pangaea break-up and birth of the westernmost Tethys Ocean: Lithos, v. 124, no. 3-4, p. 255-272.

Puga, E., Nieto, J., de Federico, A. D., Bodinier, J. a., and Morten, L., 1999, Petrology and metamorphic evolution of ultramafic rocks and dolerite dykes of the Betic Ophiolitic Association (Mulhacén Complex, SE Spain): evidence of eo-Alpine subduction following an ocean-floor metasomatic process: Lithos, v. 49, no. 1-4, p. 23-56.

Puga, E., Nieto, J. M., and De Federico, A. D., 2000, Contrasting P-T paths in eclogites of the Betic ophiolitic association, Mulhacén complex, southeastern Spain: The Canadian Mineralogist, v. 38, no. 5, p. 1137-1161.

Ranalli, G., 1995, Rheology of the Earth, Springer Science \& Business Media.

Räss, L., Duretz, T., Podladchikov, Y. Y., and Schmalholz, S. M., 2017, M2Di: Concise and efficient MATLAB 2-DS tokes solvers using the Finite Difference Method: Geochemistry, Geophysics, Geosystems, v. 18, no. 2, p. 755-768.

Rawling, T. J., and Lister, G. S., 2002, Large-scale structure of the eclogite-blueschist belt of New Caledonia: Journal of Structural Geology, v. 24, no. 8, p. 1239-1258.

Reston, T. J., Leythäuser, T., Booth-Rea, G., Sawyer, D., Klaeschen, D., and Long, C., 2007, Movement along a low-angle normal fault: The $\mathrm{S}$ reflector west of Spain: Geochemistry, Geophysics, Geosystems, v. 8, no. 6.

Reuber, G., Kaus, B. J., Schmalholz, S. M., and White, R. W., 2016, Nonlithostatic pressure during subduction and collision and the formation of (ultra) high-pressure rocks: Geology, v. 44, no. 5, p. 343-346.

Rey, P. F., Teyssier, C., Kruckenberg, S. C., and Whitney, D. L., 2011, Viscous collision in channel explains double domes in metamorphic core complexes: Geology, v. 39, no. 4, p. 387-390.

Reynolds, S. J., and Lister, G. S., 1990, Folding of mylonitic zones in Cordilleran metamorphic core complexes: Evidence from near the mylonitic front: Geology, v. 18 , no. 3 , p. $216-219$.

Reynolds, S. J., and Spencer, J. E., 1985, Evidence for large-scale transport on the Bullard detachment fault, west-central Arizona: Geology, v. 13, no. 5, p. 353-356.

Ricou, L.-E., Burg, J.-P., Godfriaux, I., and Ivanov, Z., 1998, Rhodope and Vardar: the metamorphic and the olistostromic paired belts related to the Cretaceous subduction under Europe: Geodinamica Acta, v. 11, no. 6, p. 285-309.

Ring, U., Brandon, M. T., Willett, S. D., and Lister, G. S., 1999, Exhumation processes: Geological Society, London, Special Publications, v. 154, no. 1, p. 1-27.

Robertson, Dixon, J., Brown, S., Collins, A., Morris, A., Pickett, E., Sharp, I., and Ustaömer, T., 1996, Alternative tectonic models for the Late Palaeozoic-Early Tertiary development of Tethys in the Eastern Mediterranean region: Geological Society, London, Special Publications, v. 105, no. 1, p. 239-263.

Robertson, A., 1991, Origin and emplacement of an inferred Late Jurassic subductionaccretion complex, Euboea, eastern Greece: Geological Magazine, v. 128, no. 1, p. 27-41.

Robertson, A., 2004, Development of concepts concerning the genesis and emplacement of Tethyan ophiolites in the Eastern Mediterranean and Oman regions: Earth-Science Reviews, v. 66, no. 3, p. 331-387.

Rohrmeier, M. K., Von Quadt, A., Driesner, T., Heinrich, C. A., Handler, R., Ovtcharova, M., Ivanov, Z., Petrov, P., Sarov, S., and Peytcheva, I., 2013, Post-orogenic extension and hydrothermal ore formation: High-precision geochronology of the central rhodopian metamorphic core complex (Bulgaria-Greece): Economic Geology, v. 108, no. 4, p. 691-718. 
Rolland, Y., Galoyan, G., Sosson, M., Melkonyan, R., and Avagyan, A., 2010, The Armenian Ophiolite: insights for Jurassic back-arc formation, Lower Cretaceous hot spot magmatism and Upper Cretaceous obduction over the South Armenian Block: Geological Society, London, Special Publications, v. 340, no. 1, p. 353-382.

Romagny, A., Jolivet, L., Menant, A., Bessière, E., Maillard, A., Canva, A., Gorini, C., and Augier, R., 2020, Detailed tectonic reconstructions of the Western Mediterranean region for the last $35 \mathrm{Ma}$, insights on driving mechanismsReconstructions détaillées de la Méditerranée occidentale depuis $35 \mathrm{Ma}$, implications en terme de mécanismes moteur: Bulletin de la Société Géologique de France, v. 191, no. 1.

Rosenbaum, G., Lister, G. S., and Duboz, C., 2002, Reconstruction of the tectonic evolution of the western Mediterranean since the Oligocene: Journal of the Virtual Explorer, v. 8, no. January.

Rossetti, F., Faccenna, C., and Crespo-Blanc, A., 2005, Structural and kinematic constraints to the exhumation of the Alpujarride Complex (Central Betic Cordillera, Spain): Journal of Structural Geology, v. 27, no. 2, p. 199-216.

Royden, L. H., 1993, Evolution of retreating subduction boundaries formed during continental collision: Tectonics, v. 12, no. 3, p. 629-638.

Rubatto, D., Regis, D., Hermann, J., Boston, K., Engi, M., Beltrando, M., and McAlpine, S. R., 2011, Yo-yo subduction recorded by accessory minerals in the Italian Western Alps: Nature Geoscience, v. 4, no. 5, p. 338-342.

Ruiz-Cruz, M. D., de Galdeano, C. S., and Santamaría, A., 2015, Petrology and Thermobarometric estimates for metasediments, orthogneisses, and eclogites from the Nevado-Filábride complex in the western Sierra Nevada (Betic Cordillera, Spain): The Canadian Mineralogist, v. 53, no. 6, p. 1083-1107.

Ryan, W. B., Carbotte, S. M., Coplan, J. O., O'Hara, S., Melkonian, A., Arko, R., Weissel, R. A., Ferrini, V., Goodwillie, A., and Nitsche, F., 2009, Global multi-resolution topography synthesis: Geochemistry, Geophysics, Geosystems, v. 10, no. 3.

Sánchez-Vizcaíno, V. L., Rubatto, D., Gómez-Pugnaire, M. T., Trommsdorff, V., and Müntener, O., 2001, Middle Miocene high-pressure metamorphism and fast exhumation of the Nevado-Filábride Complex, SE Spain: Terra Nova, v. 13, no. 5, p. 327-332.

Santamaría-López, Á., Lanari, P., and de Galdeano, C. S., 2019, Deciphering the tectonometamorphic evolution of the Nevado-Filábride complex (Betic Cordillera, Spain)A petrochronological study: Tectonophysics, v. 767, p. 128158.

Scharf, A., Handy, M., Favaro, S., Schmid, S. M., and Bertrand, A., 2013, Modes of orogenparallel stretching and extensional exhumation in response to microplate indentation and roll-back subduction (Tauern Window, Eastern Alps): International Journal of Earth Sciences, v. 102, no. 6, p. 1627-1654.

Schefer, S., 2012, Tectono-metamorphic and magmatic evolution of the Internal Dinarides (Kopaonik area, southern Serbia) and its significance for the geodynamic evolution of the Balkan Peninsula: University of Basel.

Schenker, F. L., Burg, J. P., Kostopoulos, D., Moulas, E., Larionov, A., and Quadt, A., 2014, From Mesoproterozoic magmatism to collisional Cretaceous anatexis: Tectonomagmatic history of the Pelagonian Zone, Greece: Tectonics, v. 33, no. 8, p. $1552-1576$.

Schermer, E. R., Lux, D. R., and Burchfiel, B. C., 1990, Temperature-time history of subducted continental crust, Mount Olympos Region, Greece: Tectonics, v. 9, no. 5, p. 1165-1195. 
Scherreiks, R., 2000, Platform margin and oceanic sedimentation in a divergent and convergent plate setting (Jurassic, Pelagonian Zone, NE Evvoia, Greece): International Journal of Earth Sciences, v. 89, no. 1, p. 90-107.

Scherreiks, R., Bosence, D., BouDagher-Fadel, M., Meléndez, G., and Baumgartner, P. O., 2010, Evolution of the Pelagonian carbonate platform complex and the adjacent oceanic realm in response to plate tectonic forcing (Late Triassic and Jurassic), Evvoia, Greece: International Journal of Earth Sciences, v. 99, no. 6, p. 1317-1334.

Schmalholz, S. M., and Duretz, T., 2017, Impact of grain size evolution on necking in calcite layers deforming by combined diffusion and dislocation creep: Journal of Structural Geology, v. 103, p. 37-56.

Schmalholz, S. M., and Fletcher, R. C., 2011, The exponential flow law applied to necking and folding of a ductile layer: Geophysical Journal International, v. 184, no. 1, p. 83-89.

Schmalholz, S. M., and Podladchikov, Y. Y., 2013, Tectonic overpressure in weak crustalscale shear zones and implications for the exhumation of high-pressure rocks: Geophysical Research Letters, v. 40, no. 10, p. 1984-1988.

Schmid, S. M., Bernoulli, D., Fügenschuh, B., Matenco, L., Schefer, S., Schuster, R., Tischler, M., and Ustaszewski, K., 2008, The Alpine-Carpathian-Dinaridic orogenic system: correlation and evolution of tectonic units: Swiss Journal of Geosciences, v. 101, no. 1, p. 139-183.

Schmid, S. M., Berza, T., Diaconescu, V., Froitzheim, N., and Fügenschuh, B., 1998, Orogen-parallel extension in the Southern Carpathians: Tectonophysics, v. 297, no. 1-4, p. 209-228.

Schmid, S. M., Fügenschuh, B., Kounov, A., Matenco, L., Nievergelt, P., Oberhänsli, R., Pleuger, J., Schefer, S., Schuster, R., and Tomljenović, B., 2019, Tectonic units of the Alpine collision zone between Eastern Alps and Western Turkey: Gondwana Research.

Schmid, S. M., Paterson, M. S., and Boland, J. N., 1980, High temperature flow and dynamic recrystallization in Carrara marble: Tectonophysics, v. 65, no. 3-4, p. 245-280.

Schneider, B., Kuiper, K., Postma, O., and Wijbrans, J., 2009, 40Ar/39Ar geochronology using a quadrupole mass spectrometer: Quaternary Geochronology, v. 4, no. 6, p. 508-516.

Schroetter, J.-M., Tremblay, A., Bédard, J. H., and Villeneuve, M. E., 2006, Syncollisional basin development in the Appalachian orogen - the Saint-Daniel Mélange, southern Québec, Canada: GSA Bulletin, v. 118, no. 1-2, p. 109-125.

Schroetter, J. M., Bédard, J. H., and Tremblay, A., 2005, Structural evolution of the Thetford Mines Ophiolite Complex, Canada: implications for the southern Québec ophiolitic belt: Tectonics, v. 24, no. 1.

Searle, M., and Cox, J., 1999, Tectonic setting, origin, and obduction of the Oman ophiolite: Geological Society of America Bulletin, v. 111, no. 1, p. 104-122.

Searle, M., Warren, C., Waters, D., and Parrish, R., 2004, Structural evolution, metamorphism and restoration of the Arabian continental margin, Saih Hatat region, Oman Mountains: Journal of Structural Geology, v. 26, no. 3, p. 451-473.

Searle, M. P., 2007, Structural geometry, style and timing of deformation in the Hawasina Window, Al Jabal al Akhdar and Saih Hatat culminations, Oman Mountains: GeoArabia, v. 12, no. 2, p. 99-130.

Seber, D., Barazangi, M., Ibenbrahim, A., and Demnati, A., 1996, Geophysical evidence for lithospheric delamination beneath the Alboran Sea and Rif-Betic mountains: Nature, v. 379, no. 6568, p. 785-790. 
Selverstone, J., 1988, Evidence for east-west crustal extension in the Eastern Alps: Implications for the unroofing history of the Tauern Window: Tectonics, v. 7, no. 1, p. 87-105.

Selverstone, J., Axen, G. J., and Luther, A., 2012, Fault localization controlled by fluid infiltration into mylonites: Formation and strength of low-angle normal faults in the midcrustal brittle-plastic transition: Journal of Geophysical Research: Solid Earth, v. 117 , no. B6.

Sfeikos, A., 1992, Analysis of deformation and kinematics of the Pelagonian nappe system, Kamvounia mountains (North Thessaly, Greece): Thesis, University of Tubingen.

Sharp, I. R., 1994, The Triassic to Tertiary sedimentary, tectonic and magmatic evolution of the Pelagonian and Vardar (Axios) zones, Macedonia, Northern Greece: University of Edinburgh.

Sharp, I. R., and Robertson, A. H., 2006, Tectonic-sedimentary evolution of the western margin of the Mesozoic Vardar Ocean: evidence from the Pelagonian and Almopias zones, northern Greece: Geological Society, London, Special Publications, v. 260, no. 1 , p. 373-412.

Simon, O., 1987, On the Triassic of the Betic Cordilleras (Southern Spain): Cuad. Geol. Iber, v. 11, p. 385-402.

Simpson, C., and Schmid, S. M., 1983, An evaluation of criteria to deduce the sense of movement in sheared rocks: Geological Society of America Bulletin, v. 94, no. 11, p. 1281-1288.

Sokoutis, D., Brun, J., Van Den Driessche, J., and Pavlides, S., 1993, A major Oligo-Miocene detachment in southern Rhodope controlling north Aegean extension: Journal of the Geological Society, v. 150, no. 2, p. 243-246.

Sokoutis, D., and Willingshofer, E., 2011, Decoupling during continental collision and intraplate deformation: Earth and Planetary Science Letters, v. 305, no. 3-4, p. 435-444.

Spakman, W., Chertova, M. V., van den Berg, A., and van Hinsbergen, D. J., 2018, Puzzling features of western Mediterranean tectonics explained by slab dragging: Nature Geoscience, v. 11, no. 3, p. 211-216.

Spray, J., Bébien, J., Rex, D., and Roddick, J., 1984, Age constraints on the igneous and metamorphic evolution of the Hellenic-Dinaric ophiolites: Geological Society, London, Special Publications, v. 17, no. 1, p. 619-627.

Stampfli, G. M., and Borel, G., 2002, A plate tectonic model for the Paleozoic and Mesozoic constrained by dynamic plate boundaries and restored synthetic oceanic isochrons: Earth and Planetary Science Letters, v. 196, no. 1, p. 17-33.

Stanek, K. P., Maresch, W., Grafe, F., Gravel, C., and Baumann, A., 2006, Structure, tectonics and metamorphic development of the Sancti Spiritus Dome (eastern Escambray massif, Central Cuba): Geologica Acta, v. 4, no. 1-2, p. 151-170.

Tamura, A., and Arai, S., 2006, Harzburgite-dunite-orthopyroxenite suite as a record of supra-subduction zone setting for the Oman ophiolite mantle: Lithos, v. 90, no. 1-2, p. 43-56.

Tate, G. W., McQuarrie, N., van Hinsbergen, D. J., Bakker, R. R., Harris, R., and Jiang, H., 2015, Australia going down under: Quantifying continental subduction during arccontinent accretion in Timor-Leste: Geosphere, v. 11, no. 6, p. 1860-1883.

Tendero, J., Martín-Algarra, A., Puga, E., and Díaz de Federico, A., 1993, Lithostratigraphie des métasédiments de l'association ophiolitique Nevado-Filábride (SE Espagne) et mise en évidence d'objets ankéritiques évoquant des foraminifères planctoniques du Crétacé: conséquences paléogéographiques: Comptes rendus de l'Académie des sciences. Série 2, Mécanique, Physique, Chimie, Sciences de l'univers, Sciences de la Terre, v. 316, no. 8, p. 1115-1122. 
Tirel, C., Brun, J. P., and Burov, E., 2008, Dynamics and structural development of metamorphic core complexes: Journal of Geophysical Research: Solid Earth, v. 113, no. B4.

Toljić, M., Matenco, L., Stojadinović, U., Willingshofer, E., and Ljubović-Obradović, D., 2018, Understanding fossil fore-arc basins: Inferences from the Cretaceous AdriaEurope convergence in the NE Dinarides: Global and planetary change, v. 171, p. 167-184.

Tomljenović, B., Csontos, L., Márton, E., and Márton, P., 2008, Tectonic evolution of the northwestern Internal Dinarides as constrained by structures and rotation of Medvednica Mountains, North Croatia: Geological Society, London, Special Publications, v. 298, no. 1, p. 145-167.

Tremblay, A., Meshi, A., Deschamps, T., Goulet, F., and Goulet, N., 2015, The Vardar zone as a suture for the Mirdita ophiolites, Albania: Constraints from the structural analysis of the Korabi-Pelagonia zone: Tectonics, v. 34, no. 2, p. 352-375.

Trotet, F., Goffe, B., Vidal, O., and Jolivet, L., 2006, Evidence of retrograde Mg-carpholite in the Phyllite-Quartzite nappe of Peloponnese from thermobarometric modelisation-geodynamic implications: Geodinamica Acta, v. 19, no. 5, p. 323-343.

Tugend, J., Gillard, M., Manatschal, G., Nirrengarten, M., Harkin, C., Epin, M.-E., Sauter, D., Autin, J., Kusznir, N., and Mcdermott, K., 2020, Reappraisal of the magma-rich versus magma-poor rifted margin archetypes: Geological Society, London, Special Publications, v. 476, no. 1, p. 23-47.

Ustaszewski, K., Kounov, A., Schmid, S. M., Schaltegger, U., Krenn, E., Frank, W., and Fügenschuh, B., 2010, Evolution of the Adria-Europe plate boundary in the northern Dinarides: From continent-continent collision to back-arc extension: Tectonics, v. 29 , no. 6.

Uunk, B., Brouwer, F., ter Voorde, M., and Wijbrans, J., 2018, Understanding phengite argon closure using single grain fusion age distributions in the Cycladic Blueschist Unit on Syros, Greece: Earth and Planetary Science Letters, v. 484, p. 192-203.

van Hinsbergen, D. J., Dupont-Nivet, G., Nakov, R., Oud, K., and Panaiotu, C., 2008, No significant post-Eocene rotation of the Moesian Platform and Rhodope (Bulgaria): implications for the kinematic evolution of the Carpathian and Aegean arcs: Earth and Planetary Science Letters, v. 273, no. 3-4, p. 345-358.

van Hinsbergen, D. J., and Schmid, S. M., 2012, Map view restoration of Aegean-West Anatolian accretion and extension since the Eocene: Tectonics, v. 31, no. 5.

van Hinsbergen, D. J., Maffione, M., Plunder, A., Kaymakcı, N., Ganerød, M., Hendriks, B. W., Corfu, F., Gürer, D., de Gelder, G. I., and Peters, K., 2016, Tectonic evolution and paleogeography of the Kırşehir Block and the Central Anatolian Ophiolites, Turkey: Tectonics, v. 35, no. 4, p. 983-1014.

van Hinsbergen, D. J., Peters, K., Maffione, M., Spakman, W., Guilmette, C., Thieulot, C., Plümper, O., Gürer, D., Brouwer, F. M., and Aldanmaz, E., 2015, Dynamics of intraoceanic subduction initiation: 2. Suprasubduction zone ophiolite formation and metamorphic sole exhumation in context of absolute plate motions: Geochemistry, Geophysics, Geosystems, v. 16, no. 6, p. 1771-1785.

van Hinsbergen, D. J., Torsvik, T. H., Schmid, S. M., Maţenco, L. C., Maffione, M., Vissers, R. L., Gürer, D., and Spakman, W., 2020, Orogenic architecture of the Mediterranean region and kinematic reconstruction of its tectonic evolution since the Triassic: Gondwana Research, v. 81, p. 79-229.

van Hinsbergen, D. J., Vissers, R. L., and Spakman, W., 2014, Origin and consequences of western Mediterranean subduction, rollback, and slab segmentation: Tectonics, v. 33, no. 4, p. 393-419. 
van Hinsbergen, D. J. J., Hafkenscheid, E., Spakman, W., Meulenkamp, J., and Wortel, R., 2005, Nappe stacking resulting from subduction of oceanic and continental lithosphere below Greece: Geology, v. 33, no. 4, p. 325-328.

Vázquez, M., Jabaloy, A., Barbero, L., and Stuart, F. M., 2011, Deciphering tectonic-and erosion-driven exhumation of the Nevado-Filábride Complex (Betic Cordillera, Southern Spain) by low temperature thermochronology: Terra Nova, v. 23, no. 4, p. 257-263.

Vergés, J., and Fernàndez, M., 2012, Tethys-Atlantic interaction along the Iberia-Africa plate boundary: The Betic-Rif orogenic system: Tectonophysics, v. 579, p. 144172.

Vidakis, M., 1995, Geological map of Greece 1:50.000.

Vidal, O., Goffé, B., and Theye, T., 1992, Experimental study of the stability of sudoite and magnesiocarpholite and calculation of a new petrogenetic grid for the system $\mathrm{FeO}-$ $\mathrm{MgO}-\mathrm{Al} 2 \mathrm{O} 3-\mathrm{SiO} 2-\mathrm{H} 2 \mathrm{O}$ : Journal of metamorphic Geology, v. 10, no. 5, p. 603614.

Vidal, O., and Theye, T., 1996, Petrology of Fe-Mg-carpholite-bearing metasediments from NE Oman: Journal of Metamorphic Geology, v. 14, no. 3, p. 381-397.

Vidal, O., Theye, T., and Chopin, C., 1994, Experimental study of chloritoid stability at high pressure and various fO 2 conditions: Contributions to Mineralogy and Petrology, v. 118 , no. 3 , p. $256-270$.

Villa, I., 1998, Isotopic closure.

Vissers, R., 2012, Extension in a convergent tectonic setting: a lithospheic view on the Alboran system of SW Europe: Geologica Belgica, v. 15, no. 1-2, p. 53.

Vissers, R., Platt, J., and Van der Wal, D., 1995, Late orogenic extension of the Betic Cordillera and the Alboran Domain: a lithospheric view: Tectonics, v. 14, no. 4, p. 786-803.

Vogt, K., Matenco, L., and Cloetingh, S., 2017, Crustal mechanics control the geometry of mountain belts. Insights from numerical modelling: Earth and Planetary Science Letters, v. 460, p. 12-21.

Vogt, K., Willingshofer, E., Matenco, L., Sokoutis, D., Gerya, T., and Cloetingh, S., 2018, The role of lateral strength contrasts in orogenesis: A 2D numerical study: Tectonophysics, v. 746, p. 549-561.

Walcott, C. R., 1998, The alpine evolution of Thessaly (NW Greece) and late Tertiary Aegean kinematics, Utrecht University.

Warren, C. J., Hanke, F., and Kelley, S. P., 2012a, When can muscovite 40Ar/39Ar dating constrain the timing of metamorphic exhumation?: Chemical Geology, v. 291, p. 79-86.

Warren, C. J., Kelley, S. P., Sherlock, S. C., and McDonald, C. S., 2012b, Metamorphic rocks seek meaningful cooling rate: Interpreting 40Ar/39Ar ages in an exhumed ultra-high pressure terrane: Lithos, v. 155, p. 30-48.

Wernicke, B., 1981, Low-angle normal faults in the Basin and Range Province: nappe tectonics in an extending orogen: Nature, v. 291, no. 5817, p. 645.

Wheeler, J., 1991, Structural evolution of a subducted continental sliver: the northern Dora Maira massif, Italian Alps: Journal of the Geological Society, v. 148, no. 6, p. 1101 1113.

Whitehead, J., Reynolds, P. H., and Spray, J. G., 1995, The sub-ophiolitic metamorphic rocks of the Québec Appalachians: Journal of Geodynamics, v. 19, no. 3-4, p. 325-350.

Whitney, D. L., and Evans, B. W., 2010, Abbreviations for names of rock-forming minerals: American mineralogist, v. 95, no. 1, p. 185-187. 
Wijbrans, J., Pringle, M., Koppers, A., and Scheveers, R., Argon geochronology of small samples using the Vulkaan argon laserprobe, in Proceedings Proceedings of the Royal Netherlands Academy of Arts and Sciences1995, Volume 2, p. 185-218.

Wijbrans, J. R., and McDougall, I., 1986, 40 Ar/39 Ar dating of white micas from an Alpine high-pressure metamorphic belt on Naxos (Greece): the resetting of the argon isotopic system: Contributions to Mineralogy and Petrology, v. 93, no. 2, p. 187 194.

Wijbrans, J. R., Schliestedt, M., and York, D., 1990, Single grain argon laser probe dating of phengites from the blueschist to greenschist transition on Sifnos (Cyclades, Greece): Contributions to Mineralogy and Petrology, v. 104, no. 5, p. 582-593.

Willingshofer, E., Sokoutis, D., Luth, S., Beekman, F., and Cloetingh, S., 2013, Subduction and deformation of the continental lithosphere in response to plate and crust-mantle coupling: Geology, v. 41, no. 12, p. 1239-1242.

Wirth, K. R., Bird, J. M., Blythe, A. E., Harding, D. J., and Heizler, M. T., 1993, Age and evolution of western Brooks Range ophiolites, Alaska: Results from 40Ar/39Ar thermochronometry: Tectonics, v. 12, no. 2, p. 410-432.

Wortel, M., and Spakman, W., 2000, Subduction and slab detachment in the MediterraneanCarpathian region: Science, v. 290, no. 5498, p. 1910-1917.

Yamato, P., Agard, P., Goffé, B., De Andrade, V., Vidal, O., and Jolivet, L., 2007, New, high-precision P-T estimates for Oman blueschists: implications for obduction, nappe stacking and exhumation processes: Journal of Metamorphic Geology, v. 25, no. 6, p. 657-682.

Yamato, P., Burov, E., Agard, P., Le Pourhiet, L., and Jolivet, L., 2008, HP-UHP exhumation during slow continental subduction: Self-consistent thermodynamically and thermomechanically coupled model with application to the Western Alps: Earth and Planetary Science Letters, v. 271, no. 1-4, p. 63-74.

Yilmaz, P., and Maxwell, J., 1984, An example of an obduction melange: The Alakir Çay unit, Antalya Complex, southwest Turkey: Melanges: Their nature, origin, and significance: Geological Society of America Special Paper, v. 198, p. 139-152.

Zheng, Y.-F., 2012, Metamorphic chemical geodynamics in continental subduction zones: Chemical Geology, v. 328, p. 5-48. 


\section{About the author}

The author of this thesis was born on July 31, 1992 in Miskolc, Hungary. In 2014 he earned his Bachelor's degree in Earth Sciences, followed by a Master's degree in Geology in 2016, both at the Eötvös Loránd University, Budapest, Hungary. In September, 2016, he started his $\mathrm{PhD}$ project in the Tectonics Research Group of the Department of Earth Sciences, Utrecht Univeristy. His $\mathrm{PhD}$ was part of the European SUBITOP project on the understanding of coupled shallow and deep processes during the evolution of subduction zones. 